GZECH-POLISH-SLOVAK STUDIES IN ANDRAGOGY AND SOCIAL GERONTOLOGY PART VII

\title{
EOTTORS:
}

\section{tukasz Tomezrk, Anorzes KumgzuK}

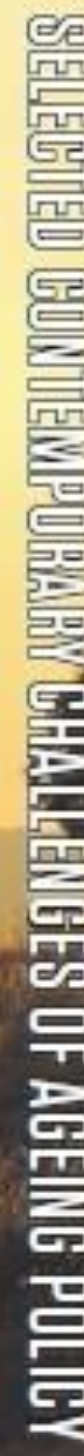

\section{SELEQTED BONIEMPORARY}

BHALLENGES OF AGEINGPOLLYY 
Department of Social Pedagogy and Andragogy PEDAGOGICAL UNIVERSITY OF CRACOW

Editors:

Lukasz Tomczyk

Andrzej Klimczuk

\section{SELECTED \\ CONTEMPORARY \\ CHALLENGES OF \\ AGEING POLICY}

Kraków 2017 


\section{CZECH-POLISH-SLOVAK STUDIES IN ANDRAGOGY AND SOCIAL GERONTOLOGY PART VII}

\section{Webpage: www.gerontolodzy.wordpress.com}

\section{Reviewers:}

doc. Mgr. Miroslav Dopita, Ph.D. - Univerzita Palackého v Olomouci doc. PaedDr. Dana Egerová, Ph.D. - Západočeská univerzita doc. Mgr. Petr Novotný, Ph.D. - Masarykova Univerzita v Brne prof. UP dr hab. Andrzej Ryk - Uniwersytet Pedagogiczny w Krakowie dr Tanja Agleitner Sagadin - Alma Mater Europaea, Maribor doc. PhDr. Jaroslav Veteška, Ph.D. - Univerzita Karlova v Praze

\section{Editor-in-Chief}

PhDr. Michal Serak Ph.D. - Univerzita Karlova v Praze

Vice Editor:

PhDr. inż. Łukasz Tomczyk PhD. - Uniwersytet Pedagogiczny w Krakowie

ISBN 978-83-941568-7-9 e-ISBN 978-83-8084-091-1

DOI 10.24917/9788380840911

Text design: Andrzej Klimczuk, Łukasz Tomczyk

Cover design: Studio Grafiki i DTP Grafpa, www.grafpa.pl Print office: fotoidruk.pl

Suggested Citation: Tomczyk, Ł., \& Klimczuk, A. (Eds.). (2017). Selected Contemporary Challenges of Ageing Policy. Kraków: Uniwersytet Pedagogiczny w Krakowie. DOI 10.24917/9788380840911

(C) Katedra Pedagogiki Społecznej i Andragogiki

\section{UNIWERSYTET PEDAGOGICZNY W KRAKOWIE}

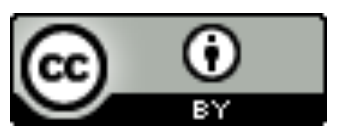

Licence: This work is licensed under a Creative Commons Attribution 4.0 International License (CC BY 4.0)

http://creativecommons.org/licenses/by/4.0/ 


\section{Contents}

INTRODUCTION

JAROSLAVA HASMANOVÁ MARHÁNKOVÁ

Seductive Solutions, Inspiration, Easy-to-Remember Phrases, and Ambiguity: Why Is the Idea of Active Ageing so Successful? 7

VALENTINA HLEBEC, TATJANA RAKAR

Ageing Policies in Slovenia: Before and After "Austerity" 27

RŪTA BRAZIENE்

Age and Workplace Discrimination in Lithuania

MAGDALENA LESZKO, BEATA BUGAJSKA

The Evaluation of Employment Policies for Older Adults in the

Czech Republic, Poland, and Slovakia

69

\section{ANGELIKA FELSKA}

Folk High School as an Educational Alternative for Older Adults

\section{ERIK SELECKÝ}

Organization of International Educational Activities at the Universities of the Third Age 
KRYSTYNA KAMIŃSKA

(Un)Obvious Education, or Complexities of the Polish Education Aimed at Older People

GIOVANNA DEL GOBBO, GLENDA GALEOTTI, GILDA ESPOSITO

Intergenerational Education for Social Inclusion and Solidarity: The Case Study of the EU Funded Project "Connecting Generations"

\section{LİGA RASNAČA, ENDIJA REZGALE-STRAIDOMA}

Intergenerational Cultural Programs for Older People in Longterm Care Institutions: Latvian Case

DOGA BASAR SARIIPEK, SEYRAN GÜRSOY ÇUHADAR Implementation of a "Self-Sufficient Ageing" Policy and Possible Challenges: Case of Turkey 


\section{Introduction}

This volume- "Selected Contemporary Challenges of Aging Policy" - is the most international of all published monographs from the series "Czech-Polish-Slovak Studies in Andragogy and Social Gerontology." Among the scholars trying to grasp the nuances and trends of social policy, there are diverse perspectives, resulting not only from the extensive knowledge of the authors on the systematic approach to the issue of supporting older people but also from the grounds of the represented social gerontology schools. In the texts of Volume VII interesting are both distinct and coherent elements presenting the role of local, regional and global policies in the prism of the countries from which the authors originate: the Czech Republic, Slovenia, Lithuania, Latvia, Poland, Slovakia, Italy, Turkey, and the United States.

The chapters show a wealth of methodological approaches to the perception of social policy and its tools. In the texts there are issues related to the idea of active ageing, discrimination against older people in the workplace, comparability of solutions friendly to employment of older adults in the Czech Republic, Poland, and Slovakia as well as focused on the importance of educational forms (universities of the third age, senior clubs, folk high schools, and other non-formal solutions) determining an active life in old age.

This monograph also attempted to answer the question regarding how to transfer the idea of intergenerational learning into the realm of practice. This issue complements the chapter on the implementation of intergenerational programs in institutions providing long-term care support. The book also outlines a public policy on ageing in the perspective of the changes over the last few decades (Slovenia) and the case demonstrating solutions to accelerate self-reliance as a key to active ageing (Turkey).

We hope that seventh volume of our series will be an intellectual stimulus for further international research on change in social policy and will contribute to the dissemination of best practices as well as contribute to positive social change.

Łukasz Tomczyk Andrzej Klimczuk 

Suggested Citation: Hasmanová Marhánková, J. (2017). Seductive Solutions, Inspiration, Easy-to-Remember Phrases, and Ambiguity: Why Is the Idea of Active Ageing so Successful? In Ł. Tomczyk \& A. Klimczuk (Eds.), Selected Contemporary Challenges of Ageing Policy (7-25). Kraków: Uniwersytet Pedagogiczny w Krakowie. Doi: 10.24917/9788380840911.1

\title{
JAROSLAVA HASMANOVÁ MARHÁNKOVÁ ${ }^{1}$
}

\section{Seductive Solutions, Inspiration, Easy-to- Remember Phrases, and Ambiguity: Why Is the Idea of Active Ageing so Successful?}

\begin{abstract}
The idea of active ageing has become one of the most influential perspectives in modern gerontology, social work, and social policy. This paper discusses factors that helped to establish active ageing as a successful theoretical concept that has significantly influenced contemporary social representations of ageing and has a practical impact on social work and policy. The perspective of the philosophy of social science is employed to explain what makes the idea of active ageing so attractive despite the remaining confusions concerning what "activity" and "ageing actively" means. The paper aims to answer the following question: What makes the concept of active ageing so successful? It draws upon the work of Murray Davis (1986) and her insight into the key aspects that make sociological theory "seductive." The paper analyzes in what ways the concept of active ageing fulfills the specific features that, according to Davis, determine the success of social theories. Simultaneously, the paper critically evaluates the ways the idea of active ageing is translated into ageing policy. The case of Czech Republic is used to illustrate the problematic aspect
\end{abstract}

\footnotetext{
${ }^{1}$ Jaroslava Hasmanová Marhánková, Department of Sociology, University of West Bohemia, Czech Republic, jmarhan@kss.zcu.cz.
} 
of active ageing policies as well as the specific rhetoric that makes the idea of active ageing so attractive for a broad spectrum of disciplines as well as for social policy.

Key words: Active Ageing, Policy Ideas, Sociological Theory

\section{Introduction}

Very few such influential concepts as active ageing are likely to be found in current social gerontology and other related fields. The term "active ageing" has earned its strong position as the basis for the vast spectrum of issues related to the lives of an older generation. At the same time, it has become an important slogan predominant in the social policies of (not only) ageing Europe. Significant attention is paid to the idea of active ageing in the social science, whether in theoretical studies discussing the numerous definitions and limits (for example, Boudiny, 2012; Moulaert \& Biggs, 2012; Walker, 2002, 2008) or empirical studies mapping the diverse dimensions of active ageing in the lives of seniors (e.g., Kuchařová, 2002, Petrová Kafková, 2013; Vidovićová, 2005). The combination of the noun "senior" and the adjective "active" is becoming a (post)modern incantation for representations of ageing. It is also becoming an increasingly visible expression of an idealized lifestyle in older age deserving support and value. The European Union (EU) declared 2012 to be European Year for Active Ageing and Solidarity between Generations. In the report on the decision, the year was highlighted as being the culmination of long-term (and still ongoing) efforts to support active ageing at all levels of social life (European Commission, 2010, p. 3). In a similar vein, the Czech National Program of Preparation for Ageing for the period 20032007, defines active ageing as the main priority (in the current version of the document the term has been replaced by "positive ageing," which, however, rather synonymously refers to the original concept).

These examples represent some of many indicators of a successful campaign for the concept of active ageing in gerontology, social policy, and media representations. The roots of the popularity of the idea of active ageing go back to the 1990 s 
when the World Health Organization (WHO) began to use the term in their policies systematically. Active ageing takes up the idea of successful ageing (Rowe \& Kahn, 1997), and later also the idea of productive ageing (Bass, Caro \& Chen, 1993), which were previously developed mainly in the United States. Similarly, to the idea of active ageing, these concepts are also based on the idea of a "suitable" form of ageing, where its stages can be identified and the subsequent desirable ones supported. Although these concepts can emphasize different aspects, their use always includes certain common principles associated with the social significance of ageing. The effort to cast doubt about the myth of non-productive ageing is becoming a compelling motive. In this regard, active ageing follows the tradition of all the concepts mentioned above. Although terms successful ageing, healthy ageing or positive ageing usually do not act as synonyms in gerontological discussions, and differing adjectives before the word "ageing" are, to a significant extent, also a response to the insufficiency and implicit exclusivity of any efforts to define a "suitable" vision of ageing, they, such as the concept of active ageing itself, work on the presumption of a relationship between activity and satisfactory ageing, and are based on similar principles (Daatland, 2005).

In this chapter, the phrase "idea of active ageing" is used to refer to a specific way of seizing ageing which follows the activity theory (e.g., Havighurst, 1961) that urge to newly re-define social significances associated with ageing and the place of older people in society. Within such approach, various forms of activity are established as the path to healthy and satisfying ageing. This conceptualization is closely related to an active lifestyle and is presented as universally suitable for everybody. The phrase "active ageing policies" refers to political strategies or social programs which, through arrangements, endeavor to put the idea of active ageing into practice.

It is striking that, despite its current popularity, it is surprisingly difficult to find a clear and comprehensive interpretation of the term "active ageing." A rather wide range of possible definitions hides behind the term "active ageing" (or "active old age"). In fact, the WHO presents active ageing as a lifelong project that does not primarily refer to physical activity as 
such, rather to ensure the possibility of participation in social affairs in all phases of life (WHO, 2002). In this conception, active ageing does not concern only individual lifestyles of older people and their physical or work activities but also emphasizes other dimensions of active engagement of older persons in the family, the community, and public activities. Thus, "activity" as perceived by the WHO is a much wider term mainly associated with efforts to improve the conditions of the lives of older citizens. In a similar vein, the Organisation for Economic Co-operation and Development (OECD) provides a broad definition of active ageing that refers to "the capacity of people, as they grow older, to lead productive lives in society and economy. This means that people can make flexible choices in the way they spend time over life-in learning, in work, in leisure, in care-giving" (OECD, 1998, p. 84). In practice, and primarily in political agendas, however, the term "active ageing" acquires rather narrower meanings. For example, a paper with the title "New Paradigm in Ageing Policy" published on the web page of European Commission states that: "in practice means adopting healthy lifestyles, working longer, retiring later and being active after retirement" (European Commission, 1999).

Similar variability in approaches to active ageing can also be found in the social sciences; Avramov \& Mašková (2003, p. 24) define active ageing as the "realization of the active lives of older people in the diverse domains of their personal, family, social and professional lives." According to them, active ageing especially refers to maintaining work activity in old age, active engagement in family life (in the form of helping family members or housework), the active engagement in community life (especially in the form of volunteering) and active use of free time. Alan Walker (2006), one of the most significant propagators of active ageing, perceives it as a multi-dimensional strategy that interconnects individual and social levels. At the social level, active ageing includes challenges in the fields of employment, health, social inclusion, education, and transportation accessibility. On the individual level, people have, according to Walker, "a duty to take advantage of lifelong learning and continuous training opportunities and to promote their own health and well-being throughout the life course" (Walker, 2006, p. 86). As is apparent 
from the previous definition, active ageing is, in many ways, a normative vision exhorting a specific lifestyle and approach to health. It is based on the assumption that "active life is positively associated with other ethically highly appreciated values such as personal autonomy, enhanced health, life satisfaction and quality of life in general" (Avramov \& Mašková, 2003, p. 24). All definitions of the concept of active ageing (as well as other terms) work with the notion of individuals who are actively striving to direct their ageing conditions towards the least possible dependence on the social system or other people (Neilson, 2006).

The recapitulation of various conceptualizations and definitions of active ageing could continue for a long time. The goal of this paper, however, is not to discuss the various modifications of active ageing or the limitations of these different approaches. This paper strives to explain the popularity of this concept and its related variations in the form of positive ageing, successful ageing and healthy ageing in the social sciences, and in social policy (despite the remaining confusions concerning what age actively means). The aim is, therefore, to provide some possible answers to the question of which factors are behind the success of active ageing as a theoretical concept and form of the social policy strategy. The following analysis is inspired by the work of Murray Davis (1986), who analyzed the roots of the success of classical social theories. This paper discusses how and to what extent the idea of active ageing meets the criteria which, according to Davis, ensure public interest and the long-term popularity of "classic" social theories.

\section{Active Ageing as a Successful Social Theory}

The works of Murray Davis (1986), focusing on the identification of the common features of successful social theories that have gained a place in social sciences canon, represent one of the main inspirations for this paper. In her work, Davis neither assess the quality of these theories, nor does she strive to map the criteria of "good" social theory, but she reflects on what distinguished theories that have gained significant attention from theories that have not. 
The second main inspiration represents the paper by Kathy Davis (2008), who applies to the arguments of her namesake onto the analysis of the success of the concept of intersectionality which, particularly in gender studies, represents one of the most influential approaches to the study of experiences of exclusion. Her analysis shows that the work of Murray Davis has the potential to bring understanding to the success of not just classical sociological theories, but also current influential concepts. This paper follows their argument and map if and how the idea of active ageing meets the criteria of a successful theory as defined by Davis (1986) and, therefore, also tries to answer the question of where the roots of its success in (not only) social sciences lie.

\section{Changes, Risks, and Seductive Solutions}

The success of a social theory is, according to Davis (1986), to a significant extent based on its attractiveness. A social theory's ability to adequately reflect the world around us is not enough to ensure its success and long-lasting popularity. It is primarily their seductiveness that, according to Davis, elevates the classical theories above those that wither away. In her analysis, she shows that all these canonical theories follow a specific form of rhetoric. Their first characteristic is that they begin their argument with reference to something that appeals to the wider audience. The success of a theory, according to Davis, however, does not only lie in the identification of an interesting topic. A theory is mainly becoming interesting to a wider audience at the moment when a fear associated with a threat to something precious and close to the audience is addressed. Such a presentation of a problem provides a context that becomes crucial for managing public concern when addressing the given question. It shows how far-reaching changes and significant processes are seen and how these interfere with the organization of society and the individual lives of people. At the same time, a successful theory offers hope in the form of reasonable proposals on how to deal with these changes and processes or, at least, how to learn to live with them (Davis, 1986).

What is it that is precious and close to everybody that is addressed by the idea of active ageing; which fears does it emphasize and simultaneously offer solutions to? The answer is 
obvious. The idea of active ageing concerns something that is a part of life for everyone of us. It addresses issues dealing with ageing and preserving dignity and independence in old age. In its simplified interpretations, the theory of active ageing provides answers to the question of how to reach healthy and satisfactory old age. A particular (and identical) rhetoric can be identified in the majority of documents formulating the vision of active ageing policies. The formulation of such policies starts with the references to statistical data on an increasing proportion of older adults in the population (e.g., WHO, 2002, pp. 6-11; European Commission, 1999). These data represent a necessary prelude showing a vision of a society which will, at least in some respects, never be the same as today. A document published by WHO (2002, p. 6) points out that this change is "one of the humanity's greatest triumphs. It is also one of our greatest challenges." Even though this challenge is also formulated in positive terms, such as opportunity, it remains a risk for society. Opportunity can be achieved, but also missed-the idea of risk is, therefore, an integral part of the formulation of active ageing policies.

Projections of population growth, which are part of the discussion on active ageing represent a symbolic risk horizon which does not necessarily have to be threatening if managed correctly. The concept of risk is associated with the modern concept of believing in the possibility of controlling one's own future, or at least the ability to change it by one's own actions (Zinn, 2008, pp. 3-4). So, the foundation of the risk is not what is happening, rather what could happen. The threat is not contained in a moment or process itself, but more likely in its poor management. As WHO argues (2002, p. 6): “countries can afford to get old if governments, international organizations and civil society enact 'active ageing' policies and programs that enhance the health, participation, and security of older citizens. The time to plan and to act is now." The idea of active ageing is becoming a tool to manage these risks and problems. The discussion on active ageing does not present population ageing as a threat as such, but as a process that can be controllable and manageable. Dangers materialize in the idea of some form of future which, however, in principle can be prevented. The population ageing is presented as 
an inherent problem which, however, can be minimized using clearly defined politics. Risks must be controlled while active ageing is presented as a preventive strategy with a universal solution.

The seductive solution that the idea of active ageing offers while dealing with the risks of population ageing is based on the production of specific subjectivities "colonized" by activity and an emphasis on productivity (Moulaert \& Biggs, 2012). As the Declaration on the European Year for Active Ageing and Solidarity between Generations published by the Council of the European Union (2012, p. 3) states: "Demographic change can, among other things, be successfully tackled through a positive life-course approach that focuses on the potential of all generations and particularly of older age groups. The action is needed to enable both women and men to remain active as workers, consumers, careers, volunteers, and citizens and to preserve the solidarity between generations." Active ageing is presented as a lifelong project, within which individuals systematically work by themselves towards minimal dependence on the social system and others. ${ }^{2}$ The state does, in this regard, have an empowering role rather-its task is to provide the conditions for active ageing, but the responsibility for its individual fulfillment remains in the hands of the individual (e.g., Hasmanová Marhánková, 2013, pp. 57-62). For example, Active Ageing Manual (2012) and the Active Ageing Guide (2013) have been published in the Czech Republic, which, even by their titles, can be in many ways considered as an incarnation of the of manuals or guides on how to produce actively ageing subjects. The Active Ageing Manual (2012), for example, appeals to its

\footnotetext{
${ }^{2}$ The emphasis on the lifelong character of the active ageing project can be perceived as another pillar of its success. The philosophy of active ageing is actually not only aimed at older adults, but presents active ageing as the result of a lifelong effort. Every individual at every stage of life should, through their lifestyle and choices, strive to age actively. Disciplinary practices associated with active ageing policies are, therefore, becoming a tool to manage the whole population.
} 
readers in the section Active Approach using chapters with titles such as "Move," "Train Your Brain," and "Meet People." The active approach to life is also presented as a way to happy ageing, because "active people live longer, are healthier, and are more satisfied" (The Active Ageing Manual, 2012, p. 47).

Active ageing call on individuals to be active with the promise of a healthier and more satisfied life. At the same time, this lifestyle becomes the key to the response to the challenges associated with population ageing. As stated, for example, by the Czech National Strategy for Positive Ageing for the period 20122017 (2012, p. 21), "the improvement of public health is closely related to economic growth and an increase in competitiveness." Management of population through active ageing, therefore, mostly occurs through the effort to gain the potential from an increasing number of older adults. Healthier, less dependent, longer working, and helpful seniors symbolizing the vision of active ageing are, in the framework of this rhetoric, also becoming the key to the solution to the economic problems associated with population ageing.

Active ageing with its vision of active seniors who continuously participate in social, economical, cultural, spiritual and civic affair (WHO, 2002, p. 12), adopt healthy lifestyle, work longer, retire later and are active after retirement (European Commission, 1999) and are aware of their responsibility for preparation for their own ageing through their whole life (National Program for Preparation for Old Age for the Period 2003-2007, 2003) represents a political response to demographic trends, as well as answers to the questions of how a satisfactory and happy old age should look. Such vision addresses not only the fears associated with individual ageing but also the fears associated with population ageing. In the same breath, it also offers guidance on how to deal with both processes.

\section{Active Ageing as an Inspiration for Specialized Research and a Reservoir of Easy-to-Remember Phrases}

The ability to open a space for specialized research and provide easy-to-remember points and phrases enabling understanding, even for those who are only marginally involved in the subject, 
represent according to Davis (1986) another key characteristic of successful social theories. She further suggests that: "an ambiguous theory can appeal to different - even hostile audience, allowing each subgroup to interpret the theory in congenial, if mutually incompatible, ways." Successful theories then, on the one hand, enable specialized academic research, where a whole career can be devoted to detailed research on just one theory. On the other hand, it is possible to simplify them into easy-tounderstand and memorable phrases or clichés (Davis, 1986).

The idea of active ageing meets this criterion fully. In the framework of social sciences, active ageing opens a space for a wide range of debates. There are studies striving to cope with former concepts of active, healthy, positive and successful ageing (e.g., Bass \& Caro, 2001; Moody, 2001), which critically assess the limits of earlier approaches and bring progressively more concepts (and thus open space for reflection on the limitations of these new approaches for other researchers). The idea of active ageing is becoming a starting point for a growing number of empirical research testing the relationship between activity in old age and life satisfaction and/or health (e.g., Nimrod \& Adoni, 2006; Litwin \& Shiovitz-Ezra, 2006), or mapping out various dimensions of senior lifestyles (e.g., Bútorová et al., 2013; Petrová Kafková, 2013). The concept of active ageing is becoming a part of a broad myriad of disciplines. It has given rise to specialized analytical tools, such as the Active Ageing Index established by the European Commission and the United Nations Economic Commission for Europe (UNECE), the aim of which is to "identify areas in which different policies and programs can promote the contribution and potential of older people" and "help in identifying priority areas of policy development in the near future" (Zaidi \& Stanton, 2015, p. 4). The Active Ageing Index is a foundation for the comparison of individuals (i.e., the higher the index, the higher the level of active ageing) and individual countries (for example, in 2014 the Czech Republic was in eleventh place among the EU countries in the rankings of active ageing). The index aims to enable the comparison and identification of areas in which countries can work better on active ageing in their own populations. 
The narrative connecting activity with the path to satisfying and healthy ageing has also played a significant role in the expansion of the field of gerontology, and in strengthening the position of social work in relation to older adults (Green, 2009; Katz, 2000). This narrative established "activity" as an important intellectual and professional capital. Active ageing does not only offer ethical frameworks for contemplating ageing but also becomes a source of specific instructions on how to fulfill this positive vision. Activity "administration," "management," and "mediation" have become expert capital (also compare Katz, 1996, 2000) and one of the most important frameworks referred to by the institutions and actors providing social services for older people when defining their roles and importance. As Katz (2000) points out, management by activity became an important way how to measure the resourcefulness and productivity of professionals working with older persons. Reference to activity became the vital part of professional vocabularies and a way how to embed the everyday life in old age into "a measurable behavior whose significance connect the worlds of older people to the largest expertise" (Katz, 2000). For example, in the Czech Republic, the relatively recently enacted Social Services Act (108/2006) institute the "process of activation" as an essential part of the work of all institutions providing services for older adults. This Act established "Strengthening life activation" as one of the crucial criteria for the definition of a social worker's job (Social Services Act 108/2006, § 116). Within this approach, activity becomes a measurable (and reportable) aspect and, at the same time, a tool connecting professional experts with the everyday lives of older persons. In this regard, discussions on active ageing also play a major role in the process of construction of the professional identity of the social services and to a significant extent help to delimit the purpose and content of institutional programs for older people.

"Active ageing" is also becoming a simple motto or slogan which easily attracts attention. The phrase "active ageing" evokes vision and dynamics. It is easily translatable into catchy phrases. In the Czech Republic, the phrase "active ageing" is currently becoming a necessary context to which almost all projects aimed 
at older people must somehow relate. So, on the one hand, active ageing opens space for detailed academic research. At the same time, however, it offers easily understandable phrases which extend its popularity well beyond the academic sphere. The use of these phrases often becomes a mantra, repeated without the need to define its meaning further. For that matter, even the National Program of Preparation for Ageing for the period 2008-2012 for the Czech Republic, which defines active ageing as its priority, does not provide a definition of the phrase anywhere in the document. It is not an exaggeration to say that a reference to active ageing is currently working almost as a compulsory pass into the arena of grant procedures for projects aimed at the older generation.

\section{The Power of Ambiguity}

According to Davis (1986), ambiguity is paradoxically the third crucial characteristic of social theory that ensures its success. In social sciences, according to Davis, ambiguity is not a sign of failure but can lay the foundations for the future popularity of a theory (Davis 1986, p. 296). Successful social theories are, therefore, successful due to the fact that they do not offer clear answers but, on the contrary, open space for further debate and research (Davis, 2008). Active ageing materializes this ambiguity in many ways. One of the characteristic features of the idea of active ageing is paradoxically an absence of the universally agreed definition of what ageing actively means. Not only is there no clear definition of active ageing, but there is also no agreement on whether active ageing represents a theory, or an approach, or even something completely different. "Active ageing" has been described as a process (WHO, 2002), an ability (OECD, 1998, p. 84), a strategy (Walker, 2002), a concept (Avramov \& Mašková, 2003; Ranzijn, 2010; Walker, 2002), a form of social politics (Ney, 2005), and a discourse (Hasmanová Marhánková, 2011). Boudiny (2013) even describes active ageing as "empty rhetoric." Alan Walker (2002), who, to a significant extent, contributed to the establishment of this concept in social sciences, also talks about the fact that active ageing "is sometimes just a slogan used 
to cover anything that seems to fit under it" (Walker, 2002, p. 124).

Boudiny (2013) recognizes three basic approaches to the definition of active ageing. One-dimensional approaches dominate the social politics of European countries and are distinguished by the reductionism described above. They frame active ageing mainly in economic terms and equates it with the participation of older citizens in the labor market. The multi-dimensional approach works with more levels of active ageing and puts the emphasis on activities beyond the labor market - mostly on actively spent free time. However, as pointed out by Boudiny, this approach also often slips towards similar reductionism, with its tendency to distinguish between passively and actively spent free time. Such a distinction not only ignores the plurality of the subjective interpretation of what activity means, but also largely excludes certain groups from being described as actively ageing (for example, due to worsening health condition, which can prevent individuals from carrying out those activities which are, in the framework of this rhetoric, considered "truly" active). The third approach does not assess active ageing only through activities and the behavior of individuals but approaches it mainly as a life situation enabling people to continue to be independent and providing sufficient conditions for personal development. This approach, however, makes active ageing inaccessible to that already facing dependence and deteriorating health (Boudiny, 2013). Despite these problems with various conceptualizations of active ageing and its criticism, many authors remain optimistic as to its potential and benefit for the politics of ageing.

The ambiguity of the definition of active ageing is, to a significant extent, based on the various definitions of the word "activity." While, in the framework of the active ageing policy, activity is mainly perceived as a tool to preserve economic productivity and independence (remaining in the labor market for as long as possible, lifelong education, maintaining an active lifestyle and, therefore, minimizing the risk of dependence on others), older persons themselves often perceive activity as the goal itself (Hasmanová Marhánková, 2011) or, in a much broader sense, as a tool for structuring leisure time and a means of relating 
to the world around them (Dyk et al., 2013). Bowling's (2008) study shows that older people most often perceive active ageing as a synonym for maintaining physical health, leisure, and social activities.

The ambivalence of active ageing and its openness to various translations is also illustrated by the way it is approached within different disciplines and institutions. While in the framework of social policy promoted by international organizations and by national strategies, active ageing is presented as an individual lifelong reflexive project where individuals take responsibility for their own ageing through their lifestyles (see above), approaches dominating in the field of social work present activity as a tool (mostly) in the hands of professionals. This approach to activity is apparent in the "process of activation" that represents a crucial aspect of the revised Social Services Act (108/2006) in the Czech Republic. The idea that one of the tasks of social workers should be to activate older clients implicitly ascribe the actor role to social workers-those who activatewhile the clients are those being activated. As stated in, for example, the Czech guide to Activation Approaches to Older People, "older people's activity can be perceived as a certain final product of the activation of older persons" (Müller, 2006, p. 37). From this perspective, being active is mostly presented as the result of the actions of social workers and specialized institutions.

An unclear definition of what active ageing means does not necessarily have to be perceived as a weakness of this perspective. On the contrary, ambiguity has become its strength and the key to its unprecedented success, especially in the context of social policies. Active ageing is becoming a framework that is easy to mobilize for various ranges of social politics. The secret of the success of active ageing paradoxically lies in the fact that, thanks to its ambiguity, it can be translated to suit the needs of diverse individuals and institutions.

\section{Conclusion}

The phrase "active ageing" (or healthy ageing, positive ageing or successful ageing) currently represent an essential framework of ageing policies and discourses on suitable forms of individual life 
in old age. As stated by Walker (2008), active ageing is currently becoming the leading global strategy in response to population ageing. In this regard, it is appropriate to ask what lies behind the success of this concept, and what are the reasons for its current leading position. This paper has attempted to outline some possible answers to these questions. The idea of active ageing undoubtedly brings fundamental and, above all, welcome changes to the ways ageing and the role of older people have traditionally been viewed. However, the popularity of the idea of active ageing throughout various disciplines and its penetration into various levels of social life cannot be explained simply by the reference to its superior ability to capture the experience of ageing. Its privileged position is also based on its specific rhetorical program, carrying those criteria identified by Davis (1986) as a foundation for the "attractiveness" and, therefore, the success of theories that have entered the history of the social sciences. Similarly, to these theories, the idea of active ageing is also framed by the discourse of a fundamental change in society and the resulting uncertainty and risks. The positive representations of ageing, which also include the image of active old age, form hand in hand with discussions pointing out the increasing number of older adults in the population as a negative phenomenon. According to Walker (2010), it was the very criticism of the welfare state fueled by notions of population ageing as a threat that gave rise to the "new ageing politics," with active ageing as its flagship concept. Demographic trends associated with population ageing draw attention to older people as a group with a specific social position and role. Active ageing is to a significant extent the product of the effort to use the potential of the growing number of older citizens (mainly at the labor market), which today's society cannot afford to "waste."

At the same time, active ageing represents a theory that is multi-layered enough to enable different disciplines and actors with different professional degrees to work with this idea. It opens space for extremely specialized research, and simultaneously is becoming a tool for practical social politics. Active ageing is becoming a buzzword - a concept that is unprecedentedly popular, even though there is very little agreement on its actual definition 
(Davis, 2008). As I have tried to outline above, the ambiguity of the idea of active ageing is one of the keys to its success. Its openness to various, often contradictory, interpretations paradoxically strengthens the privileged position of active ageing in different social spheres. Moreover, it is the very fact that different actors and institutions can use different translations of active ageing for various purposes that should be perceived as the foundation for its unprecedented success.

\section{Acknowledgements}

This paper is based on research funded by the Czech Science Foundation (grant no. 13-09399P).

\section{References}

Avramov, D., \& Mašková, M. (2003). Active Ageing in Europe. Strasbourg: Council of Europe Publishing.

Bass, S. A., Caro, F. G., \& Chen, Y.-P. (1993). Achieving a Productive Aging Society. Westport: Praeger.

Boudiny, K. I. (2013). 'Active Ageing': From Empty Rhetoric to Effective Policy Tool. Ageing and Society, 33(06), 1077-1098.

Bowling, A. (2008). Enhancing Later Life: How Older People Perceive Active Ageing? Aging \& Mental Health, 12(3), 293301.

Bútorová, Z., \& et al. (2013). The fourth dimension of the third age:

Ten chapters on active ageing [Štvrtý rozmer tretieho veku.

Desat' kapitol o aktívnom starnuti]. Bratislava: Inštitút pre verejné otázky.

Council of the European Union. (2012). Council Declaration on the European Year for Active Ageing and Solidarity between Generations (2012): The Way Forward. Retrieved from www.foragenetwork.eu/en/database/item/153-2012-councildeclaration-on-the-european-year-for-active-ageing-andsolidarity-between-generations-the-way-forward/

Daatland, S. O. (2005). Quality of Life and Ageing. In M. Johnson, V. Bengtson, P. J. Coleman, \& T. B. Kirkwood (Eds.), The Cambridge Handbook of Age and Ageing (pp. 371-377).

Cambridge, MA: Cambridge University Press. 
Davis, K. (2008). Intersectionality as Buzzword: A Sociology of Science Perspective on What Makes a Feminist Theory Successful. Feminist Theory, 9(1), 67-85.

Davis, M. S. (1986). "That's Classic!" The Phenomenology and Rhetoric of Successful Social Theories. Philosophy of the Social Sciences. (16), 285-301.

European Commission. (1999). New Paradigms in Ageing Societies.

Retrieved from http://ec.europa.eu/employment_social/socprot/ageing/news/paradigm_en.htm

Evropská rozvojová agentura. (2012). Manuál aktivního stárnutí [Active ageing manual]. Retrieved from http://aktivne.eracr.cz/wp-content/uploads/2013/01/A5manual_nahled.pdf

Fakulta humanitní studií Univerzity Karlovy v Praze. (2013). Bedekr aktivního stárnutí [Active ageing guide]. Retrieved from www.cello-ilc.cz/wp-content/uploads/2013/11/bedekr.pdf

Green, B. S. (2009). Gerontology and the Construction of Old Age. New Brunswick: Aldine Transaction.

Hasmanová Marhánková, J. (2011). Leisure in Old Age: Disciplinary Practices Surrounding the Discourse of Active Ageing. International Journal of Ageing and Later Life, 6(1), 5-32.

Hasmanová Marhánková, J. (2013). Activity as a project: The discourses of active ageing and its representations in the lives of Czech seniors [Aktivita jako projekt. Diskurz aktivního stárnutí a jeho odezvy v životech českých seniorů a seniorek]. Praha: Sociologické nakladatelství.

Havighurst, R. J. (1961). Successful Ageing. The Gerontologist. (1), $8-13$.

Katz, S. (1996). Disciplining Old Age: The Formation of Gerontological Knowledge. Charlottesville, Va., London: University Press of Virginia.

Katz, S. (2000). Busy Bodies: Activity, Ageing and the Management of the Everyday Life. Journal of Aging Studies, 14(2), 135-152.

Kuchařová, V. (2002). Život ve stáří. Zpráva z empirického výzkumu [The life in old age: The research report]. Praha: VÚPSV.

Litwin, H., \& Shiovitz-Ezra, S. (2006). The Association Between Activity and Wellbeing in Later Life: What Really Matters? Ageing and Society, 26(2), 225-242. 
Ministry of Labour and Social Affairs. (2003). Národní program př́pravy na stárnutí na období let 2003 až 2007 [National Program for Preparation for Old Age for the Period 2003-2007]. Retrieved from www.mpsv.cz/cs/2869

Ministry of Labour and Social Affairs. (2008). Národní program prŕpravy na stárnutí na období let 2008 až 2012 [National Program for Preparation for Old Age for the Period 2008-2012]. Retrieved from www.mpsv.cz/cs/5045

Moody, H. R. (2001). Productive Aging and the Ideology of Old Age. In N. Morrow-Howell, J. Hinterlong, \& M. W. Sherraden (Eds.), Productive Aging (pp. 175-194). Baltimore, MD: John Hopkins University Press.

Moulaert, T., \& Biggs, S. (2012). International and European Policy on Work and Retirement: Reinventing Critical Perspectives on Active Ageing and Mature Subjectivity. Human Relations, 1(66), 23-43.

Müller, O. (2006). Aktivizační postupy u osob seniorského věku [Approaches to activation of older people]. In Z. Kozáková \& O. Müller (Eds.), Aktivizační př́stupy k osobám seniorského věku [Activation approaches to senior citizens] (pp. 36-50).

Olomouc: Univerzita Palackého v Olomouci.

Neilson, B. (2011). Anti-Ageing Cultures, Biopolitics and Globalization. Cultural Studies Review, 12(2), 149-164.

Ney, S. (2005). Active Ageing Policy in Europe: Between Path Dependency and Path Departure. Ageing International, 30(4), 325-342.

Nimrod, G., \& Adoni, H. (2006). Leisure-styles and Life Satisfaction among Recent Retirees in Israel. Ageing and Society, 26(04), 607-630.

OECD. (1998). Maintaining Prosperity in an Ageing Society. Paris.

Petrová Kafková, M. (2013). Šedivějicí hodnoty? Aktivita jako dominantní zpưsob stárnutí [Greying values? Being active as the predomint way of ageing]. Brno: Muni Press.

Ranzijn, R. (2010). Active Ageing-Another Way to Oppress Marginalized and Disadvantaged Elders?: Aboriginal Elders as a Case Study. Journal of Health Psychology, 15(5), 716-723.

Rowe, J. W., \& Kahn, R. L. (1997). Successful Aging. The

Gerontologist. (37), 433-440. 
van Dyk, S., Lessenich, S., Denninger, T., \& Richter, A. (2013). The Many Meanings of "Active Ageing": Confronting Public Discourse with Older People's Stories. Recherches sociologiques et anthropologiques, 44(1), 97-115.

Vidovićová, L. (2005). To Be Active or Not to Be Active, That Is the Question: The Preference Model of Activity in Advanced Age. Ageing International, 30(4), 343-362.

Walker, A. (2002). A Strategy for Active Ageing. International Social Security Review, 55(1), 121-139.

Walker, A. (2006). Active Ageing in Employment: Its Meaning and Potential. Asia-Pacific Review, 13(1), 78-93.

Walker, A. (2008). Commentary: The Emergence and Application of Active Aging in Europe. Journal of Aging \& Social Policy, 21(1), 75-93.

Walker, A. (2010). The Emergence and Application of Active Aging in Europe. In G. Naegele (Ed.), Soziale Lebenslaufpolitik (pp. 585-601). Wiesbaden: VS Verlag fur Socialwissenschaft.

World Health Organization (WHO). (2002). Active Ageing: A Policy Framework. Retrieved from www.who.int/ageing/publications/active/en/index.html

Zaidi, A. \& Stanton, D. (2015). Active Ageing Index 2014: Analytical Report. UNECE/European Commission. Retrieved from www.ageplatform.eu/images/stories/Publications/AAI_2014_Report.pdf Zinn, J. (2008). Social Theories of Risk and Uncertainty: An Introduction. Oxford: Blackwell Publishing. 

Suggested Citation: Hlebec, V., \& Rakar, T. (2017). Ageing Policies in Slovenia: Before and After "Austerity". In Ł. Tomczyk \& A. Klimczuk (Eds.), Selected Contemporary Challenges of Ageing Policy (27-51). Kraków: Uniwersytet Pedagogiczny w Krakowie. Doi: 10.24917/9788380840911.2

\section{VALENTINA HLEBEC ${ }^{1}$}

\section{TATJANA RAKAR ${ }^{2}$}

\section{Ageing Policies in Slovenia: Before and After "Austerity"}

Abstract: Similarly, to other European countries, Slovenia is facing ageing of the population. The European Year for Active Ageing and Solidarity between Generations in 2012 (EY2012) and the recent economic crisis have influenced social policy in the area of ageing and care for older people. While the EY2012 has raised awareness about issues related to the ageing of the population, the economic crisis after 2008 has put pressure on the welfare system. The purpose of the chapter is to examine the influences of the EY2012 together with the changes in social policies, i.e., austerity measures, which were the results of economic crisis. We analyzed the dominant trends in the development of the care for older people (including both institutional care and home care services), starting from 1992, when Slovenia gained independence, until the recent economic crisis. We have confirmed the main thesis, claiming that the EY2012 had beneficial effects in raising the awareness about population ageing in general population, but was not followed by the policy development, which would be useful

\footnotetext{
${ }^{1}$ Valentina Hlebec, Faculty of Social Sciences, University of Ljubljana, Slovenia, valentina.hlebec@fdv.uni-lj.si.

${ }^{2}$ Tatjana Rakar, Faculty of Social Sciences, University of Ljubljana, Slovenia, tatjana.rakar@fdv.uni-lj.si.
} 
for older people. Moreover, the social policy development was marked by results of austerity measures, which significantly worsen the quality of life of older people and their families.

Key words: Austerity, Care Services, Economic Crisis, LongTerm Care

\section{Introduction}

Similarly, to other European countries, Slovenia is facing relatively rapid ageing of the population. The recent development of social policy in the area of ageing and care for older people has been under the influence of recent economic crisis as well as of the European Year for Active Ageing and Solidarity between Generations in 2012 (EY2012). The economic crisis after 2008 has put pressure on the welfare system. The purpose of the chapter is to identify the dominant trends in the development of the care for older people (including both institutional care and home care services), starting from 1992 when Slovenia gained independence until the recent economic crisis. We will focus on the changes in policies for older people with the introduction of the austerity measures and how this affected the quality of life of older people in Slovenia regardless awareness process raised by the EY2012. We will examine the development and changes in the ageing policies in Slovenia within the recent policy discourse of the main trends in welfare policies such as de-familialization and refamilialization (Blum et al., 2014), individual responsibility, increased selectivity (Taylor-Gooby et al., 2017) and delegated governance (Morgan \& Campbell, 2011; Greve, 2015).

The first part of the chapter will give a short overview of the ageing policies after the Slovenia independence in 1992. The second part will focus on the description of the main changes that were introduced with the new social legislation and austerity laws as a consequence of the global economic crisis. The next two sections will present the data on the main trends in institutional care and home care and the policy issues with an emphasis on the development of welfare mix in the shared responsibility of the state, market, and the community (focusing on the role of civil society organizations and the family). Particular attention will be 
paid to the issue how these policy changes have affected the social situation of older persons and their quality of life. Our main thesis is that despite the special attention to ageing issues and ageing policies advocated through the EY2012 those policies in Slovenia were not sheltered from "austerity measures" and retrenchment trend was evident in all areas and has significantly affected the social situation and quality of life of older people in Slovenia.

\section{Ageing Policies in the Framework of the Slovene Welfare System Before and after the Crisis}

Slovenia is a small country that was once part of Yugoslavia and the established socialist regime. Through the specific circumstances of the development of former socialist societies, a particular type of welfare system ${ }^{3}$ evolved: a state-socialist welfare system, in which the state had the dominant role. The state was the owner, financier, and controller of all institutions and organizations that provided services or paid for the provision of social protection and welfare of its citizens. An important fact regarding the development of the Slovene welfare system during the transition period in the 1990s is that, contrary to some other post-socialist countries, Slovenia did not experience a so-called "welfare gap" (see Kolarič et al., 2009, 2011). Hence, in the context of the transition from socialist to post-socialist society, the Slovene welfare system went through gradual reforms and constituted as a dual model, combined with elements that are the basic constitutive elements on one side of the conservativecorporate. On the other side, social-democratic welfare system. First of all, the compulsory social insurance systems (including old age), which are based on social partnership and are as such the basic constitutive element of a conservative-corporate welfare

\footnotetext{
${ }^{3}$ The welfare system we understand as a concept that embraces not only the institutions, programs and measures with which the state provides social protection and social well-being to its citizens, but also those evolving and functioning according to the logic of the market, as well as those operating within the domain of civil society, the community and the family (Kolarič et al., 2009, 2011).
} 
system, are in Slovenia the primary instrument for the provision of social protection for employees and their family members. On the other hand, the strong public and state sector maintained the status of the main service provider of all types of services to which all citizens are equally entitled. Gradually, a complementary relationship between public and state and the non-profit voluntary sector was established, as well as state support for the informal sector. The characteristics mentioned above are distinctive elements of the social-democratic welfare system (Kolarič et al., 2009, 2011).

In terms of services for older people, the system in Slovenia had three components: the public sector, the informal sector and the "grey" sector. In the public sector, a well-developed and regionally dispersed network of public (state) organizations and institutions provided formally organized professional services, including numerous institutions for the care of older people (nursing homes). The second sector-the informal sectorprovided services that were lacking in the public sector. They were provided by close and extended family members, friends, and neighbors. This voluntary and unpaid provision of services, largely based on strong value orientations, normative expectations and emotional closeness within informal networks (Nagode et al., 2004; Filipovič Hrast, \& Hlebec, 2008, 2009; Hlebec \& Filipovič Hrast, 2009; Hlebec, 2009, 2010), was not supported by policy measures. The last sector, that is, the grey sector (Kolarič, 1992; Kolarič et al., 2009) comprised employees in public institutions and organizations who were offering services for direct (illegal) payment and was tolerated by the state for its compensatory role.

Hence, at the beginning of the transition, Slovenia built its care policies for older people on a well-developed tradition of institutional care (Nagode et al., 2004; Mali, 2009). On the other hand, community care services, such as home care, day care, and others have developed only after the transition. The development of community care was relatively supported in the policy documents. For example, the National Program on Social Protection 2006-2010, the Program for Development of Care for Older People in the Field of Social Protection until 2005, and the Strategy of Care for Older Adults 2006-2010. 
The National Social Protection Strategy by 2005 and the Resolution on the National Social Protection Program 2006-2010 defined new forms of mobile assistance, day care centers, care in a family other than the birth family and care in sheltered housing for older people. The Social Security Act (MDDSZ, 2006a; Amendment to the Social Security Act, 1992) defined services for social prevention, and services intended for eliminating social distress and difficulties (first social aid, personal help, help to the family, institutional care, guidance, protection and employment under special conditions, help to workers in enterprises, institutions and at other employers). One measure related to care for older people is the possibility for a family member to become a family attendant with the right to partial payment for lost income at the minimum wage level or to a proportional part of the payment for lost income in the case of part-time work (Hlebec, 2010).

Policy measures since 1991 have targeted both the development of institutional care and support for older people living at home and their careers. However, the persistence of the characteristic of the previous system through "path dependency" is clearly evident in the slow development of home care services. This services still cover a very small part of older people (approx. $3 \%$ ) while the adoption of these services by older persons currently is not growing anymore, mainly due to financial inaccessibility (Nagode et al., 2013). Flexible forms of care and support for family careers are still underdeveloped (see Filipovič Hrast \& Hlebec, 2009; Mali, 2008). Adoption of a coherent longterm care act has been discussed for a decade and drafts have been prepared. However, the actual adoption of such an Act is still pending.

In regard to pension system the main issue throughout the period was the financial sustainability due to unfavorable demographic trend further exacerbated by the early retirement policy as a solution to solve high unemployment rates following transition of Slovenia to market economy, which placed an additional burden on the national pension system (Filipovič Hrast $\&$ Rakar, 2015). Slovenia has the so-called pay-as-you-go pension 
system that is based on three pillars (the first is compulsory, and the other two are supplementary).

\section{Ageing Policies in Times of Economic Crisis and "Austerity" Discourse}

More recently following the trends of the "Great Recession," the well-developed welfare systems have been under significant pressures due to the recent economic crisis and demographic pressures. Slovenia enjoyed strong economic growth before the crisis but faced one of the most pronounced recessions among the countries members of The Organization for Economic Cooperation and Development (OECD) in 2009. The gross domestic product (GDP) growth after 2008 was negative and shows a slower recovery than in 28 European Union (EU) member states (Eurostat). On the other side, as in many other European countries, Slovenia is facing an ageing of the population. The old age dependency ratio was $24.4 \%$, in 2012 , which is slightly below the EU27 average. However, it is projected to rise to $57.6 \%$ in 2060 (Eurostat). Hence, what has been in the public, policy and media arena most discussed is the sustainability of the pension system.

In Slovenia, the pension reform has been highly contested, and the first proposed major reform was rejected at the referendum (in 2011). In 2012, a new reform was negotiated and adopted, increasing the retirement age, and further strengthening bonuses and maluses to stimulate labor market participation of older workers (Filipovič Hrast \& Rakar, 2015).

The economic situation of older people has deteriorated since 2001, with the most affected being those aged 75+ (Kump \& Stropnik, 2009; Stropnik et al., 2010; Stropnik et al., 2003) and the poverty rates among older people are high (20.5\% in 2014) (Eurostat). It is therefore not surprising that evaluations of the quality of the pension system are rather negative and the average has decreased from 5.1 in 2003 to 4 in 2011 (EQLS 2003, 2011). 
Since economic crisis austerity laws have been adopted in $2012,{ }^{4}$ which froze pension indexation and pension adjustments, further affecting the living standards of older people. These acts introduced temporary austerity measures with an unpredictable time limit, as they will be in force until the year that follows the year in which the economic growth exceeds $2.5 \%$ of GDP. These reforms made benefits for older people and social benefits more means-tested and lowered the level of some benefits.

Furthermore, besides the austerity measures introduced by the austerity laws as a direct response to the crisis, there was a major reform in welfare policies, with the adoption of the new social legislation which came into force on 1 January 2012 with two acts: the Exercise of Rights to Public Funds Act and the Financial Social Assistance Act, regulating the noncontributory social benefits. The implementation of the two acts brought significant changes in the field of social benefits and subsidies. For the first time the law introduced a common entry point to access all family and social benefits, it defined uniform criteria for eligibility for different benefits and for accessing income and property of households. Besides including a wider definition of family income (taking property and savings into account) it also set an order in which benefits are being claimed. According to the main goals of the new legislation, this was supposed to ensure a fairer distribution of social transfers and targeting the most deprived. However, the data show worsening of the financial situation and well-being of some of the most vulnerable groups and among those also older people (Dremelj et al., 2013). Most important was the change in supplementary allowance that pensioners with lower pensions were eligible (also those residing in institutional care). Now, the additional allowance is no longer granted on the basis of pension and disability rights but became a social benefit and people residing in institutional care are no

\footnotetext{
${ }^{4}$ As a direct response to the crisis two intervention acts were adopted. The first, Act on Additional Intervention Measures for 2012, came into force on 1 January 2012, the same day as the new social legislation. The second, Fiscal Balance Act, came into force on 31 May 2012.
} 
longer eligible for it. Consequently, the number of beneficiaries dropped dramatically by $78 \%$ between 2011 and 2012 (Trbanc et al., 2014). Furthermore, the striking drop in the number of beneficiaries can be linked to stricter conditions for accessing benefits, taking into account a broader definition of income (including property). The most important change was a state mortgage on the property of those receiving a supplementary allowance as well as social assistance recipients. This relates to issue of the "take-up of benefits," since the implemented changes resulted in "non-take-up of benefits" from older people in fear of losing their property as well as the property inheritance rights of their children. Moreover, state pensions were abolished, which used to be a universal right and support for older people not eligible for insurance-based pensions. Those older persons have now become dependent on social assistance and supplementary allowance, now changed to social assistance benefit, and hence dramatically reduced the number of beneficiaries (Trbanc et al., 2014).

Due to the problems with the implementation of the new social legislation and its negative impact, there were subsequent modifications of the new social legislation that came into force on January 1, 2014, and September 1, 2014. The changes involved softening of some of the access rules in terms of income and property calculations in accessing the benefits and less strict rules in regard to property mortgage for the supplementary allowance ${ }^{5}$ and social assistance beneficiaries. ${ }^{6}$ Despite the positive connotation of these improvements, this was more "make-up" changes and as shown by data did not have an effect on the increase in the number of beneficiaries (see Trbanc et al., 2016, pp. 53-54).

\footnotetext{
${ }^{5}$ Limitation of inheritance rights only to $2 / 3$ of the value of the assets.

${ }^{6}$ The return of the received social assistance benefits applies only to beneficiaries that received social assistance for more than 12 months with the adjusted return of funds minus 12 months of the highest amounts and minus $1 / 3$ of the monthly amounts of social assistance.
} 
The described changes in the ageing policy, which can be labeled under the trend of increased selectivity, have happened despite older people having a strong political presence, as their political party, the Democratic Party of Slovenian Pensioners (DESUS), has been part of every governing coalition since the earliest years of independence (1996). Also, the EY 2012 activities did not have any major effect on improving the position of older people or to shelter them from the major cuts in policies and benefits. This could be explained by the fact that the focus of the activities was mainly on raising the awareness on active ageing and intergenerational solidarity, promoting discussions, good practices and preventing discrimination on the basis of age in general. However, topics in regard to illness and disability, employment and active work were much less pronounced. Very few actions were directed to policy makers (Narat et al., 2012). The activities within the EY 2012 made a good basis for further work in this area. Still, in the future, the focus should be more on the concrete proposals and actual implementation of active projects (Narat et al., 2012).

In terms of the austerity measures, there were no major reforms in regard to services for older people. However, in practice, a trend toward the privatization of services is evident, both in institutional services as well as home care services. Hence, a trend toward "contracting out" and delegated governance in the service provision for older people can be noticed. In terms of ageing policy developments, the changes in social protection benefits for older persons and on the other in the service provision, have resulted in some more pronounced issues of the affordability of services in institutional care as well as home care services as shown in the next section.

\section{Developments in Institutional Care}

The institutional care in Slovenia is by tradition well developed. Mali (2009) refers to three main periods of the development. Namely, the first period before the transition was a sociogerontological period, where nursing homes were designed as geriatric institutions focused on sick old people. The period after a transition from 1991 to 2000 as a hospital model of nursing homes 
where hospital-like rules of living were in use. The period after 2000 as a social model of institutional care. The implementation of this last model has been based on a rising number of people who have dementia and the inability of the medical model of care to provide highly individualized care. In the following paragraphs, the development of institutional care will be presented in figures. Data was gathered from various sources, mostly from the Statistical Office of the Republic of Slovenia (SURS) but also from other institutions such as the Association of Social Institutions of Slovenia (SSZS), the Ministry of Labour, Family, Social Affairs and Equal Opportunities (MDDSZ) and the Social Protection Institute of the Republic of Slovenia (IRSSV). A detailed list of sources is given below each table.

The number of institutions along with the number of residents has been increasing throughout the whole period, which is in line with the demographic trends producing a greater need for institutional care as shown in Table 1. However, what is unexpected, is that in 2012 there was a decrease in the number of residents in institutional care, which could be linked to the effects of the economic crisis and introduced austerity measures as well as the described changes in the social legislation exacerbating the issue of the affordability of the institutional care.

The average pension was raising up to 2009 as shown in Figure 1. In 2012 there was a significant drop in average pension, with a slight increase in 2013 and again dropping in 2014 and 2015. Halting of the increase in pensions and even the lowering of the level of pensions along with constant increase in the expenses for nursing homes and the decrease in the public funds from the health insurance budget (SSZS, 2016), could explain the decrease in the number of residents due to the possible drop out from institutional care as they were no longer able to afford the services. Additionally, the described changes in the social legislation in 2012 contributed to this drop, since we would expect that the lowering of the pension levels would be supplemented by municipality funds, however, this was not the case, due to take-up of benefits gap, since the beneficiaries did not apply for them by fearing of losing their property (SSZS, 2016). 
Table 1 Nursing Homes and People in Care

\begin{tabular}{|r|r|r|}
\hline & Old people's homes & Number of residents \\
\hline 1990 & 53 & 11,260 \\
\hline 1991 & $\mathrm{NA}$ & $\mathrm{NA}$ \\
\hline 1992 & 53 & 11,178 \\
\hline 1993 & $\mathrm{NA}$ & $\mathrm{NA}$ \\
\hline 1994 & 50 & 10,664 \\
\hline 1995 & 47 & 10,757 \\
\hline 1996 & 48 & 11,057 \\
\hline 1997 & 47 & 11,500 \\
\hline 1998 & 48 & 11,645 \\
\hline 1999 & 50 & 11,951 \\
\hline 2000 & 49 & 11,905 \\
\hline 2001 & 55 & 12,346 \\
\hline 2002 & 58 & 13,051 \\
\hline 2003 & 61 & 13,498 \\
\hline 2004 & 63 & 13,098 \\
\hline 2005 & 68 & 13,641 \\
\hline 2006 & 69 & 13,699 \\
\hline 2007 & 69 & 13,856 \\
\hline 2008 & 84 & 15,235 \\
\hline 2009 & $83 *$ & 17,676 \\
\hline 2010 & 89 & 18,195 \\
\hline 2011 & 91 & 18,076 \\
\hline 2012 & 93 & 18,352 \\
\hline 2013 & 93 & 18,643 \\
\hline 2014 & 93 & 18,247 \\
\hline 2015 & 94 & 15,99417 \\
\hline 5025, & & 17 \\
\hline
\end{tabular}

Source: SURS, 2004, 2007: 2009; Association of Social Institutions of Slovenia 2009-2015. *Reported data are about the number of residential units and differs from data reported by SURS, which reports about the number of residential institutions among which some may have more than one residential unit. *Reported on December 31 of each year.

The salient issue of the affordability of the institutional care exacerbated by economic crisis, the austerity measures and increased selectivity within the changes in the social legislation is also evident in Figure 2, showing the trends in the difference between users' daily payments and average gross pension level per day. 


\section{Figure 1 Average Pension}

Average pension in $€$

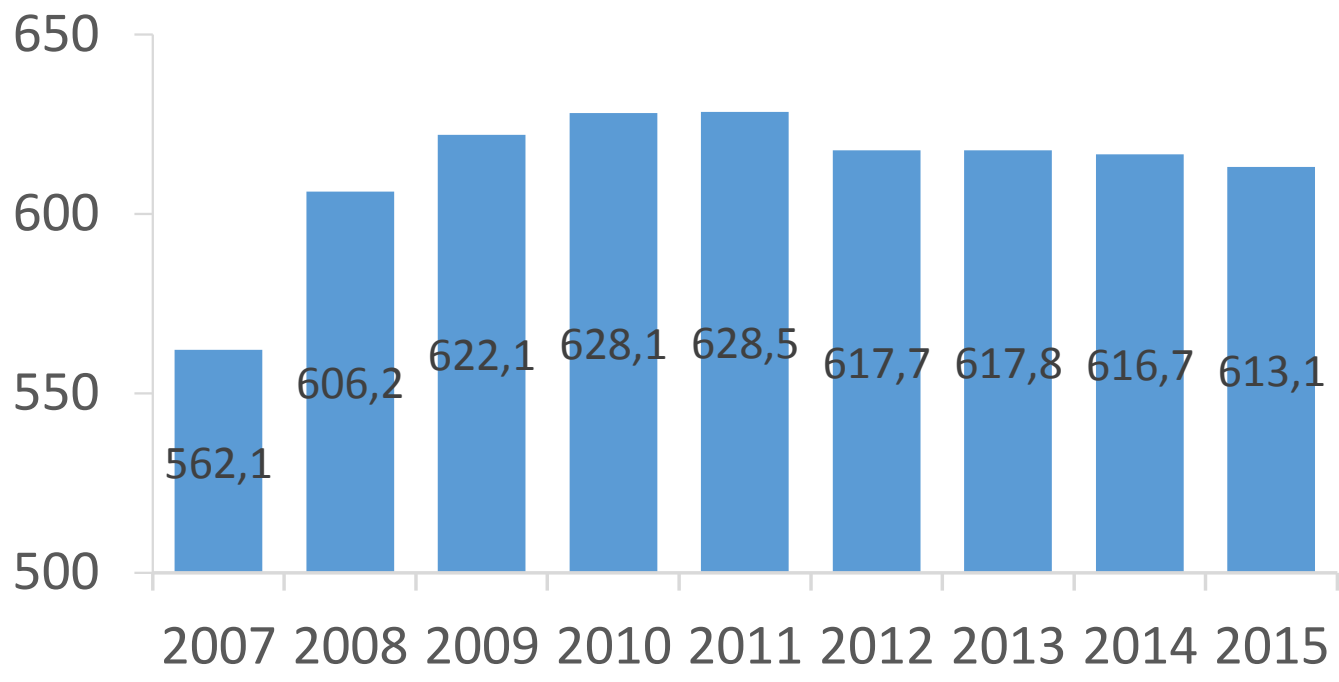

Source: SSZS, 2016, p. 8.

Figure 2 Difference Between Users' Daily Payments and Average Gross Pension Level per Day

- Average gross pension level per day in $€$

Daily payments by source in $€$

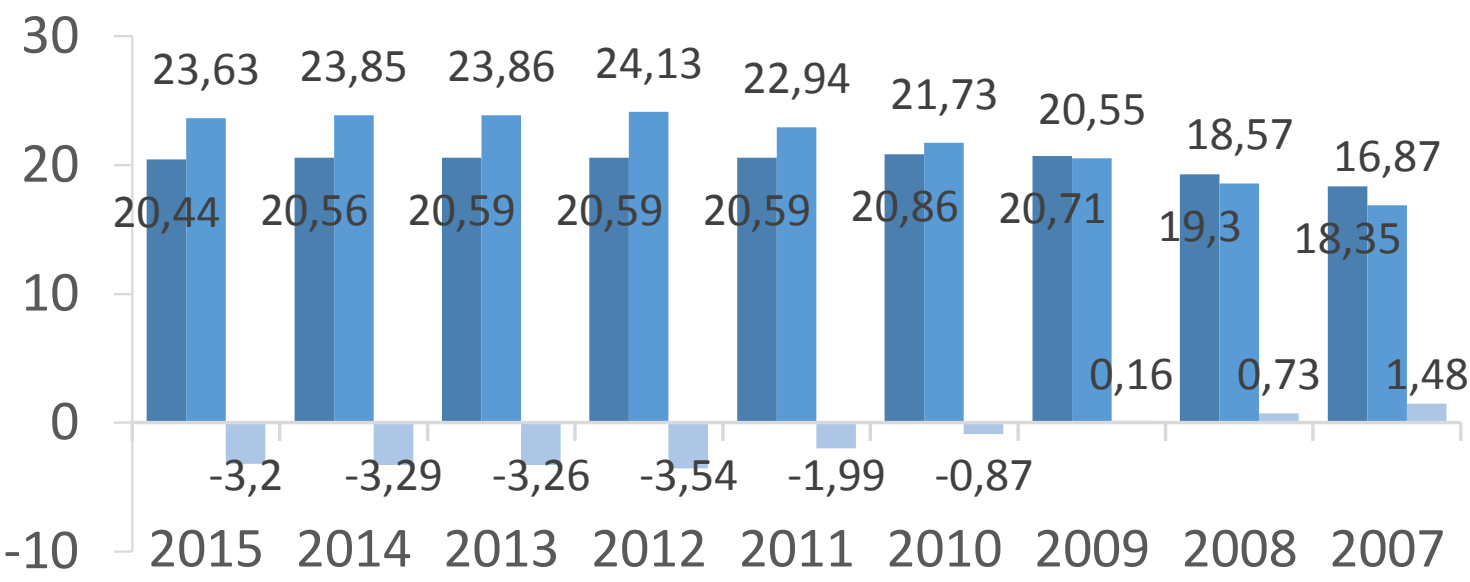

Source: SSZS, 2016, p. 8.

There was a sharp decrease in the ability to pay after 2010 when the average pension was no longer covering the average 
expenses of the nursing homes (SSZS, 2016). Taking into account the more restrictive legislation for the eligibility of social transfers (e.g., state mortgage on real estates), this significantly increased the burden on families and relatives for the payment of services as well as taking care of the family members indicating a trend toward re-familialization and greater emphasis on individual responsibility. Perhaps also the increasing number of private homes for older people with higher daily payments has contributed to the trend.

The issue of affordability of services combined with the quality of services could become one of the salient issues in the future, and it is something that should be urgently addressed by the welfare state in Slovenia. Furthermore, we should have a closer look at the structure of the provision of institutional care for older people in regard to the type of providers and trends in the examined period as shown in Table 2 .

Table 2 Public/private Nursing Care Institutions

\begin{tabular}{|l|r|r|}
\hline & Private (licensed) & Public \\
\hline 2001 & 5 & 58 \\
\hline 2002 & 5 & 58 \\
\hline 2003 & 11 & 58 \\
\hline 2004 & 11 & 59 \\
\hline 2005 & 14 & 60 \\
\hline 2006 & 18 & 60 \\
\hline 2007 & 18 & 60 \\
\hline 2008 & 28 & 56 \\
\hline 2009 & $28 / 32 *$ & $55 / 55^{*}$ \\
\hline 2010 & 34 & 55 \\
\hline 2011 & 36 & 55 \\
\hline 2012 & 39 & 54 \\
\hline 2013 & 39 & 54 \\
\hline 2014 & 39 & 54 \\
\hline 2015 & 40 & 54 \\
\hline
\end{tabular}

Source: Dremelj et al., 2009: 98; Association of Social Institutions of Slovenia, 2007, p. 16 and 2007, pp. 24-31; Association of Social Institutions of Slovenia 2009-2015. *Reported data are about the number of residential units and differs from data reported by SURS, which reports the number of residential institutions among which some may have more than one residential unit. *Reported on December 31 of each year. 
In 2001 there were only five private providers of institutional care for older people, and in 2015 the number was 40 institutions in private provision of care. Hence, during the last 15 years we have seen a rising number of privately-owned nursing homes with a licensed care program (the vast majority also have concessions) and a decrease in the number of public institutions, showing a trend toward the privatization of services in terms of contracting out the services to private providers instead of filling the demand by establishing public institutions (by the state or municipality). The price of services in private nursing homes is defined and approved by the state. However, the private institutions are in general more expensive than the public institutions, which is not always the case of higher standards in comparison to public institutions. In terms of a number of residents in private institutions, there was a smaller increase than in the number of private institutions itself. However, also showing an increased trend toward contracting out as a way of privatization of services. A closer look at the list of private providers of institutional care (SSZS, 2016 ${ }^{7}$ ), shows that those are registered in different forms. Among the non-profit organizations, many of them are established by the Roman Catholic Church. The majority of private providers are for-profit institutions, showing a trend in the direction of the liberal welfare system as defined by Kolarič et al. (2002). The public intuitions are still predominant. However, the trend of privatization in the direction of market provision and marketization of services should be taken into account when discussing the current changes in ageing policies.

\section{Developments in Social Home Care}

Social home care is a social assistance service which was developed in the first half of the 1990s by centers of social work. Its first occurrence dates to 1984 (Nagode et al., 2016, p. 910). It is a social assistance service intended to improve the quality of life

\footnotetext{
${ }^{7}$ A list of all institutional care providers in Slovenia is available on the webpage of Association of Social Institutions of Slovenia (www.sszslo.si/seznam-domov-clanov-s-povezavami, 21.12.2016).
} 
of people living at home who are unable to care for themselves due to old age or illness and whose family cannot provide them with sufficient care. It was developed to cut the number of waiting applicants for nursing homes and to improve the quality of life of those living at home. An individual is eligible for up to 4 hours of care per day or a maximum of 20 hours per week. In 1992 in legislation concerning social protection, the social home care was established as social protection service as a part of public social protection network. A year before that the state has introduced cofinancing of the services by public works (Nagode et al., 2016). Along with expansion and professionalization of the service in the next decade, the payment for users was introduced in 2000. In 2001 the Ministry of Labour, Family Affairs, and Social Affairs had introduced a special financial support for the social home care by contributing to the labor costs of the service provider by partially covering the costs of salaries for workers that participated in public works program before that. The measure was in place until 2011 (Nagode et al., 2016). The financial burden of the service is now partially carried by the municipality, which by law is obliged to cover at least $50 \%$ of the cost of the service. Users are obliged to pay the rest of the costs of the social home care, if unable to cover for financial burden; firstly the family members must contribute to the payment if able. Only if family resources are insufficient users can apply for a reduction of payment.

The first evaluations of how the service has been implemented show slow uptake of the service, the number of users reported from 3.909 in 1998 up to 7.100 in 2015 as shown in Table 3. Early evaluations of the service show considerable variability in users' financial contribution ranging from 1.90 EUR up to 10.94 EUR (Hlebec, 2010) and point out that not every municipality provided at least $50 \%$ of the cost of the service. The Social Protection Institute of the Republic of Slovenia (IRSSV) has started to evaluate the service in 2006 systematically, and to date, nine reports are publicly available. We summarize major trends in terms of a number of users, users cost, and type of providers. 
Table 3 Number of Social Home Care Users

\begin{tabular}{|l|r|}
\hline & $\begin{array}{r}\text { Number of social home care } \\
\text { users } \mathbf{6 5 +}\end{array}$ \\
\hline 1998 & 3.909 \\
\hline First half of 2002 & 4.590 \\
\hline At the end of 2004 & 4.732 \\
\hline 2006 & $4.612,7^{*}$ \\
\hline 2007 & $4.880,3^{*}$ \\
\hline 2008 & $5.096,8^{*}$ \\
\hline 2009 & $5.676^{* *}$ \\
\hline 2010 & $5.764^{* *}$ \\
\hline 2011 & $5.827^{* *}$ \\
\hline 2012 & $5.801^{* *}$ \\
\hline 2013 & $6.540^{* *}$ \\
\hline 2014 & $6.888^{* *}$ \\
\hline 2015 & $7.100^{* *}$ \\
\hline
\end{tabular}

*An average number of users per month; ${ }^{* *}$ Number of users on December 31 each year.

Source: Compiled from Nagode et al., 2016, pp. 11-13; Lebar et al., 2015, p. 23.

The municipalities are obliged to provide social home care services, which means that they need to provide a public network of services and establish a concession agreement with at least one of the providers either public or private. For example, in 2006 six municipalities did not provide social home care services and, for instance, in 2015 two municipalities did not provide social home care (Nagode et al., 2016). Hence, the coverage of services improved but still, they are not provided in all municipalities, or as shown in the IRSSV evaluation they are provided on paper but not in practice (Nagode et al., 2016).

Among the home care providers, the majority are public institutions (centers for social work), followed by nursing homes (the data about the public vs. private types of nursing homes is not available). From 2007 till 2015 there was an increase in the number of municipalities that contracted out the services to private providers (for 23 municipalities) or the nursing home or special social institutions (for 31 municipalities), and there was a decrease in the number of municipalities where centers for social work provide home care services (for 43 municipalities) or specialized 
institutions for home care (for 4 municipalities) (Nagode et al., 2016 , p. 27). By comparing the number of municipalities where social home care is provided by private institutions with those where home care is provided by public institutions, we can notice a trend of the decrease in the number of municipalities with public providers (from 186 to 170) and at the same time the number of municipalities with private providers of social home care is increasing (from 19 to 42) (Nagode et al., 2016, p. 27). In regard to the affordability of services, the average price for services is the highest from the private providers with concessions. Also, the subventions from municipalities are in average lower for private providers than for public institutions (Nagode et al., 2016, p. 32). Although in the recent years there was a decrease in the prices of home care (Nagode at al., 2016), the increase in the private providers of home care, which are more expensive in comparison to public providers, may exacerbate affordability issues of home care services in the future.

Hence, as shown by the presented data in terms of social home care services providers we can notice a trend toward privatization of services in terms of contracting out the services to private non-profit (civil society organizations) and for-profit providers such as companies and individual entrepreneurs, which at the same time increases the price of services and exacerbates the affordability issues of social home care services.

\section{Conclusion: Major Trends in Ageing Policies Marked by "Austerity"}

The purpose of the chapter was to identify the dominant trends in the development of the care for older people (including both institutional care and home care services), starting from 1992 when Slovenia gained independence until the recent economic crisis. We focused on the changes in policies for older people, more specifically on the introduction of the austerity measures and the major reform in welfare policies regulating noncontributory social benefits as well as the major trends in the service provision, and how this affected the quality of life of older people population in Slovenia, regardless awareness process raised by the EY2012. We examined the development and changes in the ageing policies 
in Slovenia within the recent policy discourse of the main trends in welfare policies such as de-familialization and re-familialization, individual responsibility, delegated governance, and increased selectivity.

The first finding is that the financial situation of older people has worsened in the recent years as a consequence of changes in the ageing policy in Slovenia comprised of austerity measures and reform of the social legislation. These induced the salient issues of service affordability, which forced older people to drop out from the nursing homes as shown by the data on nursing homes. It also caused severe problems of financial access to the home care services for the majority of older people. Hence, the introduced changes show a trend toward more reliance on individual responsibility for the well-being as well as a trend toward re-familialization, forcing older people to rely more on the families twofold regarding home help and in terms of financial help. Besides, there is a pronounced trend toward increased selectivity based on means-testing criteria in order to be eligible for benefits and services financed by the state. These trends are evident in a tightening of the criteria on one side for different social benefits for older people as well as public (co)financing of the services for older people.

The second finding is that in regard to service provision we can interpret the recent trends in policy developments in terms of different roles of service providers such as supplementary or complementary role to the public services (Rakar, 2007). As shown by the data on the level of privatization of services a trend toward the subsidiary role of other providers, such as non-profit as well as for-profit organizations, besides the state, is evident in institutional care and home care services. The role of other providers, rather than the state, is no longer only complementary to the services provided by the public sector. More specifically, other providers, especially the non-profit voluntary organizations, acted as an alternative to the services of the public sector in the past, not replacing those services, but only contributing to the freedom of choice as the vast majority of services was provided by the public sector. In the recent developments of the increased reliance of municipalities on the private provision of services, by 
non-profit as well as for-profit providers, the trend towards the subsidiary role of other service providers can be noticed. The private providers are not only complementing the services, provided by the public sector in terms of freedom of choice, but they are also replacing them by filling up the gap of the withdrawal of public providers. In other terms, the state or municipality, rather than providing its own services, contracts out service delivery to other providers in line with austerity measures and retrenchment of the welfare state in general. More specifically, it can be labeled under the trend of delegated governance as the "delegation of responsibility for publicly funded social welfare provision to non-state actors" (Morgan \& Campbell, 2011, p. 19).

Finally, our main conclusion is, that regardless of the beneficial effects of EY2012, such as raising the awareness on active ageing and intergenerational solidarity, promoting discussions, good practices and preventing discrimination on the basis of age, the ageing policy in Slovenia severely suffered from the effects of the economic crisis and consequent austerity measures, which had a prevailing impact on the quality of life of older population and their families. A more comprehensive approach to ageing policies in Slovenia is becoming one of the major issues that should be tackled by the Slovenian welfare state in the future.

\section{References}

Blum, S., Formánková, L., \& Dobrotic, I. (2014). Family Policies in 'Hybrid' Welfare States after the Crisis: Pathways Between Policy Expansion and Retrenchment. Social Policy \& Administration, 48(4), 468-491.

Dovšak, J. (2010). Institucionalno varstvo starejših - neprofitna ali profitna dejavnost? [Institutional care for older people-nonprofit or profit activity?]. Ljubljana: Faculty of Social Sciences.

Dremelj, P., Kobal, B., Smolej, S., Nagode, M., \& Žiberna, V. (2009). Spremljanje učinkov izvajanja Resolucije o nacionalnem programu socialnega varstva 2006-2010. Poročilo za leto 2009 [Monitoring the effects of the implementation of the Resolution of national program of social protection 2006-2010. Report for 
2009]. Ljubljana: Social Protection Institute of the Republic of Slovenia (IRSSV).

Dremelj, P., Smolej, S., Boškić, R., Narat, T., Rihter, L., Kovač, N., $\&$ et al. (2013). Ocena učinkov izvajanja nove socialne zakonodaje, končno porocilo. [Evaluation of the effects of the implementation of new social legislation, final report].

Ljubljana: Social Protection Institute of the Republic of Slovenia (IRSSV).

Državni zbor RS. (1992). Health Care and Health Insurance Act.

Retrieved from

http://zakonodaja.gov.si/rpsi/r03/predpis_ZAKO213.html

Filipovič Hrast, M., \& Hlebec, V. (2008). Skrb za starejše v Sloveniji

[Care for older people in Slovenia]. In Družba in vrednote.

Povzetki referatov [Society and values: summary of

presentations]. Ljubljana.

Filipovič Hrast, M., \& Hlebec, V. (2009). Medgeneracijska

solidarnost v Sloveniji in tranzicijske spremembe

[Intergenerational solidarity in Slovenia and transitional

changes]. In V. Tašner, I. Lesar, M. G. Antić, V. Hlebec, \& M.

Pušnik (Eds.), Brez spopada: kultur, spolov, generacij [Without

conflict: of cultures, genders and generations] (pp. 195-214).

Ljubljana: Pedagoška fakulteta.

Filipovič Hrast, M., \& Rakar, T. (2015). The Future of the Slovenian

Welfare State and Challenges to Solidarity. In 2015 Annual

ESPAnet Conference: The Lost and the New Worlds of Welfare.

Odense: University of Southern Denmark.

Greve, B. (2015). Welfare and the Welfare State: Present and Future. London, New York, NY: Routledge Taylor \& Francis Group.

Hlebec, V. (2010). The Post-socialist Transition and Care for Older

People in Slovenia. European Papers on the New Welfare. (15),

141-152. Retrieved from

http://eng.newwelfare.org/2010/10/20/the-post-socialisttransition-and-care-for-older-people-in-slovenia-2/

Hojnik-Zupanc, I., Ličer, N., \& Hlebec, V. (1996). Varovalno alarmni sistem kot socialna inovacija $\mathrm{v}$ slovenskem prostoru [Security alarm systems as a social innovation in Slovenia]. Zdravstveno varstvo. (35), 289-294. 
Jacović, A. (2009). Javni socialnovarstveni zavodi, Slovenija, 20062008 [Public social protection institutes]. Retrieved from www.stat.si/novica_prikazi.aspx $? \mathrm{id}=2638$

Javornik, J. S. (2006). Socialni razgledi 2006 [Social views 2006]. Retrieved from http://miha.ef.unilj.si/_dokumenti3plus2/191029/Socialni_razgledi_UMAR_2006. pdf

Kolarič, Z. (1990). Socialna politika in družbene spremembe [Social policy and social changes], (PhD dissertation). Ljubljana:

Fakulteta za sociologijo, politične vede in novinarstvo.

Kolarič, Z. (1992). From Socialist to Post-socialist Social Policy. In I. Svetlik (Ed.), Social Policy in Slovenia: Between Tradition and Innovation. Avebury: Ashgate.

Kolarič, Z., Črnak-Meglič, A., \& Vojnovič, M. (2002). Zasebne neprofitno-volonterske organizacije $v$ mednarodni perspektivi [Private nonprofit-voluntary organizations in international perspective]. Ljubljana: Založba FDV; Fakulteta za družbene vede.

Kolarič, Z., Kopač, A., \& Rakar, T. (2009). The Slovene Welfare System: Gradual Reform Instead of Shock Treatment. In K. Schubert, S. Hegelich, \& U. Bazant (Eds.), The Handbook of European Welfare Systems (pp. 444-461). London, New York: Routledge.

Kolarič, Z., Kopač, A., \& Rakar, T. (2011). Welfare States in Transition: The Development of the Welfare System in Slovenia. In S. Dehnert \& M. Stambolieva (Eds.), Welfare States in Transition: 20 Years After the Yugoslav Welfare Model (pp. 288-309). Sofia: Friedrich Ebert Foundation.

Kolarič, Z., Rakar, T., \& Kopač, M. (2009). Slovenski sistem blaginje $\mathrm{v}$ procesu postopnega spreminjanja [Slovene welfare system in the process of gradual changes]. In V. Hlebec (Ed.), Starejsi $i$ ljudje $v$ družbi sprememb [Older people in a society of changes] (pp. 45-75). Maribor: Aristej.

Kump, N., \& Stropnik, N. (2009). Socialno-ekonomski položaj starejšega prebivalstva [Socio-economic position of older people]. In V. Hlebec (Ed.), Starejši ljudje v družbi sprememb [Older people in a society of changes] (pp. 77-93). Maribor: Aristej. 
Lebar, L., Kovač, N., \& \& Vidrih, N. (2015). Izvajanje pomoči na domu. Analiza stanja v letu 2014. Končno poročilo

[Implementation of social home care. Analysis for 2014: Final report]. Ljubljana: Social Protection Institute of the Republic of Slovenia (IRSSV).

Mali, J. (2009). Spremembe v institucionalnem varstvu starejših [Changes in institutional care for older people]. In V. Hlebec (Ed.), Starejši ljudje v družbi sprememb [Older people in a society of changes] (pp. 95-107). Maribor: Aristej.

MDDSZ - Ministrstvo za delo, družino in socialne zadeve. (1997). Program razvoja varstva starejših oseb na področju socialnega varstva v Sloveniji do leta 2005 [Program for the development of care for older people in the field of social protection in Slovenia until 2005]. Retrieved from www.mddsz.gov.si/fileadmin/mddsz.gov.si/pageuploads/dokum enti_pdf/program_starejsi_2005.pdf

MDDSZ - Ministrstvo za delo, družino in socialne zadeve. (2006a). Social Security Act. Retrieved from www.mddsz.gov.si/fileadmin/mddsz.gov.si/pageuploads/dokum enti_pdf/zsv_upb2_en.pdf

MDDSZ - Ministrstvo za delo, družino in socialne zadeve. (2006b). Strategija varstva starejših do leta 2010 - Solidarnost, sožitje in kakovostno staranje prebivalstva [Strategy for care for older people until 2010: Solidarity, coexistence and quality ageing]. Retrieved from www.mddsz.gov.si/fileadmin/mddsz.gov.si/pageuploads/dokum enti_pdf/strategija-SI-starejsi.pdf

MDDSZ - Ministry of Labour, Family and Social Affairs. (2008). National Report on Strategies for Social Protection and Social Inclusion 2008-2010. Ljubljana.

MDDSZ - Ministry of Labour, Family and Social Affairs. (2014). Učinki pokojninske reforme in nadaljni koraki [The effects of pension reform and future steps]. Retrieved from www.mddsz.gov.si

Morgan, K. J., \& Campbell, A. L. (2011). The Delegated Welfare State: Medicare, Markets and the Governance of Social Policy. New York, Oxford: Oxford University Press.

Nagode, M. (2009). Organizirana pomoč za stare ljudi. ki živijo na domu. Pomoč na domu in varovanje na daljavo [Formal support 
for older people living at home: Home help and a security alarm system]. In V. Hlebec (Ed.), Starejši ljudje v družbi sprememb [Older people in a society of changes]. Maribor: Aristej.

Nagode, M., \& Lebar, L. (2013). Izvajanje pomoči na domu. Analiza stanja v letu 2012 [Implementation of social home care: Analysis for 2012]. Ljubljana: Social Protection Institute of the Republic of Slovenia (IRSSV).

Nagode, M., Kolarič, Z., \& Hlebec, V. (2004). Delovanje in vrednotenje varovalno alarmnega sistema za starostnike [Functioning and evaluation of security alarm system for older people]. Kakovostna starost, 1(7), 21-34.

Nagode, M., Lebar, L., Kovač, N., \& Vidrih, N. (2016). Izvajanje pomoči na domu. Analiza stanja v letu 2015. [Implementation of social home care: Analysis for 2015]. Ljubljana: Social Protection Institute of the Republic of Slovenia (IRSSV).

Narat, T., Lebar, L., Nagode, M., Boškić, R., \& Dremelj. P. (2012). Spremljanje in ocenjevanje izvajanja Evropskega leta aktivnega staranja in solidarnosti med generacijami 2012 [Monitoring and evaluation of the implementation of the European Year for Active Ageing and Solidarity between Generations in 2012]. Ljubljana: Social Protection Institute of the Republic of Slovenia (IRSSV).

Rakar, T. (2007). Razvoj cerkvenih šol v postsocialističnih družbah [The development of church schools in postsocialist societies]. (Znanstvena knjižnica, 58). Ljubljana: Fakulteta za družbene vede.

Skupnost socialnih zavodov Slovenije (SSZS). (1998). Strateški razvojni program organizirane skrbi za starejše [Strategic development program for organized care for older people]. Ljubljana.

Skupnost socialnih zavodov Slovenije (SSZS). (2007). 40 let skupnosti socialnih zavodov Slovenije [40 years of the Association of social institutions of Slovenia]. Ljubljana.

Skupnost socialnih zavodov Slovenije (SSZS). (2010). Number of Applicants. Retrieved from http://prosnje.sszslo.si/SSZSHtmlPregledi/pregled_cakajocih.aspx Skupnost socialnih zavodov Slovenije (SSZS). (2016). Poudarki iz analiz področja institucionalnega varstva starejših in odraslih $\mathrm{s}$ posebnimi potrebami [Emphasis from the analyzes of the 
institutional care for older people and people with special needs]. Retrieved from www.sszslo.si/Media/Default/Page/2015-

Poudarki\%20iz\%20analiz\%20\%20Skupnost $\% 20$ socialnih\%20za vodov\%20Slovenije.pdf

Smolej, S., Jakob, P., Nagode, M., \& Žiberna, V. (2008a). Analiza izvajanja pomoči na domu [Analysis of social home care]. Ljubljana: Social Protection Institute of the Republic of Slovenia (IRSSV).

Smolej, S., Nagode, M., Jakob, P., Žiberna, V., Jerina, P., \& Kenda, A. (2008b). Izvajanje pomoči na domu. Analiza stanja za obdobje januar-junij 2008 [Implementation of social home care: Analysis for the period January-June 2008]. Ljubljana: Social Protection Institute of the Republic of Slovenia (IRSSV).

Stropnik, N., Kump, N., Filipovič Hrast, M., Hlebec, V., Vezovnik, A., \& Kavčič, M. (2010). Revščina in materialna deprivacija starejšega prebivalstva: projekt v okviru Ciljnega raziskovalnega programa Konkurenčnost Slovenije 2006-2013v letu 2006 [Poverty and material deprivation of older people: project within the Targeted research programe Competitiveness of Slovenia 2006-2013 in 2006]. Ljubljana: Inštitut za ekonomska raziskovanja.

Stropnik, N., Stanovnik, T., Rebolj, M., \& Prevolnik-Rupel, V. (2003). Study on the Social Protection Systems in the 13 Applicant Countries - Slovenia, Country Study. Retrieved from http://europa.eu.int/comm/employment_social/socprot/social/slovenia_final.pdf

SURS - Statistični urad Republike Slovenije. (2004). Rapid Reports. Retrieved from www.stat.si/doc/statinf/12-SI-044-0401.pdf

SURS - Statistični urad Republike Slovenije. (2005). Rapid Reports, Social Protection. Retrieved from www.stat.si/doc/statinf/12-SI044-0501.pdf

SURS - Statistični urad Republike Slovenije. (2006). Rapid Reports, Social Protection. Retrieved from www.stat.si/doc/statinf/12-SI044-0601.pdf

SURS - Statistični urad Republike Slovenije. (2007). Rapid Reports, Social Protection. Retrieved from www.stat.si/doc/statinf/12-SI044-0701.pdf 
SURS - Statistični urad Republike Slovenije. (2008). Si-stat podatkovni portal. Domovi za starejše (2006-2008). Retrieved from

www.stat.si/pxweb/Database/Dem_soc/12_socialna_zascita/02_ soc_varstvo/12623-socio-DOM/12623-socio-DOM.asp

Taylor-Gooby, P., Leruth, B., \& Chung, H. (2017). After Austerity:

Welfare State Transformation in Europe after the Great Recession. Oxford: Oxford University Press.

Trbanc, M., Smolej, S., Dremelj, P., Boljka, U., Lebar, L., \& Narat, T. (2016). Socialni položaj v Sloveniji 2014-2015 [Social situation in Slovenia 2014-2015]. Ljubljana: Social Protection Institute of the Republic of Slovenia (IRSSV).

Trbanc, M., Smolej, S., Dremelj, P., Črnak Meglič, A., Kobal Tomc, B., \& Kovač, N. (2014). Socialni položaj v Sloveniji 2013-2014, končno poročilo [Social situation in Slovenia 2013-2014, final report]. Ljubljana: Social Protection Institute of the Republic of Slovenia (IRSSV). 

Suggested Citation: Brazienè, R. (2017). Age and Workplace Discrimination in Lithuania. In Ł. Tomczyk \& A. Klimczuk (Eds.), Selected Contemporary Challenges of Ageing Policy (53-68). Kraków: Uniwersytet Pedagogiczny w Krakowie. Doi: 10.24917/9788380840911.3

\section{RŪTA BRAZIENE் $\dot{E}^{1}$}

\section{Age and Workplace Discrimination in Lithuania}

Abstract: This paper aims to disclose an expression of age and workplace discrimination in the Lithuanian labor market. The paper is discussing theoretical aspects of age discrimination and presents the results of the sociological survey research results carried out in 2014. The purpose of this paper is to disclose age and workplace discrimination at the Lithuanian labor market. Analysis of scientific literature and quantitative research results allows to state that older adults are experiencing discrimination because of, among others, their age, gender, and stereotypes. Research results revealed that age and workplace discrimination is increasing with the age of the respondents, e.g., the expression in older age groups is more intensive. For the age group of 40-50, age discrimination is lower than the full sample average. Age discrimination is exposing for the age group of 56-60 and is the most intensive for persons 60 years old and older. The research results revealed that older employees have obstacles for career and future perspectives; older people are more often facing discriminative behavior, lacking social justice, insufficient personal respect labor relations, and are more often experiencing pressure to leave the job or facing unreasonable dismissal.

Key words: Age Discrimination, Labor Market, Older Workers

\footnotetext{
${ }^{1}$ Rūta Braziene, Lithuanian Social Research Centre, Institute of Labour and Social Research, ruta.braziene@dsti.lt.
} 


\section{Introduction}

By the processes of constant ageing of the Lithuanian society, the older adults constitute larger and larger part of the population. According to a myriad of studies, people are living longer; healthier, and productive lives and projections of the population growth for the next 50 years indicate that this trend will continue at an alarming rate (Turner, 2008). Their active participation in the labor market is a critical factor for the sustainable development of society. However, it should be noted that also in many other countries of the European Union, the labor market participation decreases with age. The analysis of the Eurostat Labour Force Survey (LFS) data (2004-2015) allows to state, that the older the person, the more likely that she/he will experience discrimination and disadvantages on the labor market.

Possibilities for successful participation in the labor market is decreasing not only by the age, but also by other factors, e.g., gender, disability, lack of appropriate education, and poor or inadequate professional qualification. National and international research results revealed that 50-55 years old persons are experiencing first difficulties on the labor market (Eurobarometer, 2012; ILO, 2012). Persons 50-55 years old not only the experience social exclusion in job search processes but more often than young persons' experiencing age discrimination at the workplace (Eurobarometer, 2012a; Larja et al., 2012).

Older age becomes a problem for successful participation in the labor market due to age discrimination, older adult's health problems, and lack of appropriate or modern skills. Age discrimination in the labor market acquires various forms, e.g., discriminatory job advertisements, lack of professional retraining and dismissal before reaching old age pensions. Eurobarometer (2012) research revealed that 50-55 years old persons are facing negative stereotypes on the labor market, when older persons were identified as inefficient, inflexible, unable to adapt to innovations and technological progress. A Eurobarometer survey carried out in 2009 revealed an opinion of Lithuanian population about the prevalence of discrimination. As the most prevalent form of 
discrimination respondents indicated age discrimination (59\%) (Eurobarometer Survey, 2009).

Enhancing of the older adults' social inclusion into the labor market is one of the Lithuanian and European Union social policy priorities. In European social charter, which Lithuania ratified in 2001 is stated that one of the main goals and responsibilities of the EU member states is greater and more stable employment, free choice of employment, and an adequate standard of living. The European Council Directive 2000/78/EC is requiring the EU member states to introduce legislation prohibiting age and several other forms of discrimination (Taqi 2002, p. 117). Age discrimination is prohibited in Lithuanian legal and strategic documents: The general principle of equal opportunities and equal treatment is enshrined in the Constitution of the Republic of Lithuania (Article 29), the Law on Equal Opportunities for Women and Men (1998), and the Law for Equal Treatment (2005). Another key policy is the National Program on Equal Opportunities for Women and Men for 2015-2021, approved in 2015. Other relevant legal documents regulating women and men integration into the labor market is Labour Code (2002) and Law on support on Employment (2016). In the Lithuanian Labour Code (2002) Article 92 states that "additionally in the labor market supported individuals (unemployed), having or likely to have difficulty finding a job because of lack of qualifications or work experience, long-term unemployment, or disability, as well as persons five years prior to retirement age."

Theoretical discourse about age discrimination is widespread. There is a wide variety of research carried out. The main directions of the age and workplace discrimination research are the following:

- Older persons labor market participation trends (Semykina, Linz, 2007; Lazutka, Skucienè, 2005; Gruzevskis, 2006a; Okuneviciute-Neverauskiene, Moskvina, 2008; Eurostat, 2012; Eurobarometer, 2012a).

- Quality of Employment and Productiveness of Older Workers (McMullin et al., 2004; Hardy, 2011; UKCES, 2011). 
- Older People Labor Market Discrimination (Riach, Rich, 2007; Sargeant, 2011; Eurobarometer 2012b; Eurobarometer, 2012b; Okuneviciūtè-Neverauskiene, 2011).

- Active Ageing and Gender Equality (Corsi, Lodovici, 2013).

It is important to stress that research on age and workplace discrimination is rather limited in Lithuania. Older adults integration into the labor market research is mainly focusing on older people labor market participation possibilities (Gruzevskis et al, 2006a; Lazutka, Skučienè, 2005; OkuneviciuteNeverauskiene, Moskvina, 2008), the demand for professional training and consultation (Gruzevskis et al, 2006b; OkuneviciuteNeverauskiene, Moskvina, 2007), and social consequences of the labor market ageing (Raskinis, 2008). There are also some attempts to analyze older people labor market discrimination (Okuneviciute-Neverauskiene, 2011).

The purpose of this paper is to disclose age and workplace discrimination at the Lithuanian labor market. The research questions are the following: What are the main obstacles for older people participation in the Lithuanian labor market? What types of discrimination older people are experiencing in the Lithuanian labor market? Research methods: analysis of scientific literature and legal documents and factor analysis.

\section{Theoretical Considerations}

Research from different scholars indicates that age discrimination in the labor market is an important problem (e.g., Walker, 1993; Walker; 2005; Mykletun, 2010). Discrimination has a variety of forms. In the documents of the EU, there is a clear distinction between direct and indirect discrimination. Direct age discrimination is when inappropriate situations in the labor market persons because of her or his age were treated less favorably. Nondirect discrimination occurs when because of certain behavioral practices, criteria, older people find themselves in less favorable situations in the labor market (O'Cinneido, 2005).

Age discrimination is commonly seen as an obstacle for older people participation in the labor market. The concept of age discrimination is primarily identified by Butler (1969). She 
described stereotypes and different discriminatory practices towards older adults. Also, age discrimination can be understood as a "particular decisions towards employee based not on the employee competence or abilities, but on a biological age" (Arrowsmith, 2003).

Concerning the age, it is possible to distinguish different aspects of an age, e.g., biological age, psychological age, e.g., "individual ability to adapt their behavior to the needs of the environment and social age," which indicates "social norms and roles apply to individual age depending on the culture and society" (Sterns, Miklos, 1995).

It should be noted that depending on the individual factors (e.g., gender and health status), age group, and employment content, ageing workers represent a very heterogeneous group in the labor market. Age discrimination is also a phenomenon that is deeply rooted in the workplace and the labor market (Laczkó, Phillipson, 1991). Scholars are asserting that age stereotypes that are widely prevalent in society diminish older persons' possibilities in work organizations and the labor market (Arrowsmith, 2003).

\section{Forms of Age Discrimination in the Workplace}

Age discrimination pervades the entire employment relationship and can take a variety of forms. It occurs in relation to, among others, access to a job, to promotion, salary differentials, and access to training. Ageism or age discrimination on the labor market primarily manifested as prejudice, discriminatory or institutional practice of older persons. According to Binstock (1983), ageism is not only an adequate reflection of negative attitudes but also can form some stigma, when older persons are referred as weaker, less competent and/or they are to be treated in an exceptional way.

Looking at previous research on age discrimination in the labor market, we can state that it manifests in very different forms. Direct discrimination occurs when older people are looking for a new or better job. Also, older persons more often facing a risk that they will not be promoted, will not get salary supplement (Furunes et al., 2008). Older workers are, among others, less frequently 
offered to attend various courses, and to seek for professional development (Schone, 1996; Taylor, Urwin, 2001; Mykletum, 2006). Taylor and Urwin argue that the fact that older people significantly less involved or offered to participate in various training reflects the fact that employers tend to invest in younger workers, with the latter linked the prospects of the company's activities (Taylor, Urwin, 2001).

Age discrimination is often considered as a barrier to participation in work by older people, and the workplace provides the most common grounds for that. Age discrimination predominantly affects older rather than younger groups, and it is based on myths and stereotypes attitudes about older people and older workers (e.g., Davey, 2007; Alpes's, Mortimer, 2007; Gray, McGregor, 2003). Age discrimination pervades the entire employment relationship and can take a variety of forms. It occurs in relation to access to, among others, a job, to promotion, salary differentials, and access to training. Moreover, older workers are not only facing fewer professional development opportunities but also rarely raised the salary (Brooke, 2003).

Garstka, Schmidt, et al. (2003) conducted a survey on discrimination. Although the study was not directly focusing on the labor market discrimination, it revealed that the age discrimination negatively affects the quality of life, social wellbeing, and satisfaction with life in general. Another study carried out by Chou and Chow indicated that age discrimination could have far-reaching consequences for an individual's economic and psychological well-being (Chou, Chow 2005).

\section{Survey Research Methodology and Results Research Sample}

The survey research was conducted in 2014. The respondents to the study were selected using the following: age (40-74) and an individual's labor market status (currently in employment, unemployed, and retired or not retired). The random cluster sampling method was used. A quantitative representative sample of older person survey was conducted within 5 percent error-Rate at 95 percent reliability. In a representative survey research, 974 persons aged 40 to 75 years old participated. Every third 
respondent was 40-49 years old, every second-50-59 years, and one in sixth was older than 60 years. This sample fully corresponds to the demographical characteristics of the Lithuanian population. The survey sample represents the entire territory of Lithuania. By education, mostly interviewed people with a bachelor's degree (48.7 percent), Having a college education consists of 16.1 percent. According to the labor market status, 71 percent of the respondents currently employed.

\section{Research Results}

Age discrimination in the workplace measured by the 14 indicators (see Table 1).

Table 1 Complex Age Discrimination in the Workplace Index, N=747

\begin{tabular}{|c|c|c|}
\hline Primary indicators & 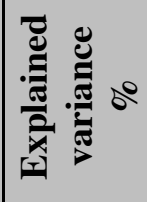 & $\begin{array}{l}\mathbf{L} \\
\text { /it. }\end{array}$ \\
\hline Age discrimination in the workplace (complex index) & \multirow[t]{15}{*}{62,7} & \\
\hline Restricted work-related benefits & & ,841 \\
\hline Restricted work-related promotion & & ,835 \\
\hline Experienced pressure to leave job & & ,834 \\
\hline $\begin{array}{l}\text { Lack equal opportunities to participate in the activities of } \\
\text { work organization }\end{array}$ & &, 833 \\
\hline Demotion in working position & & ,823 \\
\hline Restricted training or learning opportunities & & ,814 \\
\hline Conducted extra certification & & 8,800 \\
\hline Fewer tasks or restriction of functions, responsibilities & & ,796 \\
\hline $\begin{array}{l}\text { Compared with other co-workers' lower wages for the } \\
\text { same tasks }\end{array}$ & & ,760 \\
\hline Fired from work for no reason & & ,758 \\
\hline $\begin{array}{l}\text { The allocation for tasks, shifts, etc. disregarded the needs } \\
\text { of employee }\end{array}$ & & ,756 \\
\hline An employee was disrespected by the jokes or comments & & ,751 \\
\hline $\begin{array}{l}\text { No recognition, appraisal, or acknowledgment for work } \\
\text { achievements }\end{array}$ & & ,747 \\
\hline Not accepted to the workplace & & ,726 \\
\hline
\end{tabular}


For the evaluation of the scale reliability, Spearman-Brown coefficient was used $(0,926$ and 0,907$)$. This indicated the very high quality of constructed scale. Factor analysis was used, and complex age discrimination in the workplace index (covering all 14 primary indicators) was created. Created index complies with the requirements and scale intervals of normality condition; all statistical methods (including parametric methods) can be applied without any restrictions.

The study was aimed to assess the link between workrelated discrimination and age. For the data analysis, ANOVA test was selected. This test allows determining statistically significant differences in more than two groups. In this case, the expression of discrimination was compared in more than six different age groups $40-45,46-50,51-55,56-60,61-65$, and 65 and older age groups.

\section{Figure 1 Expression of Discrimination in the Different Age} Groups (Discrimination Scale, ANOVA, p=0,007)

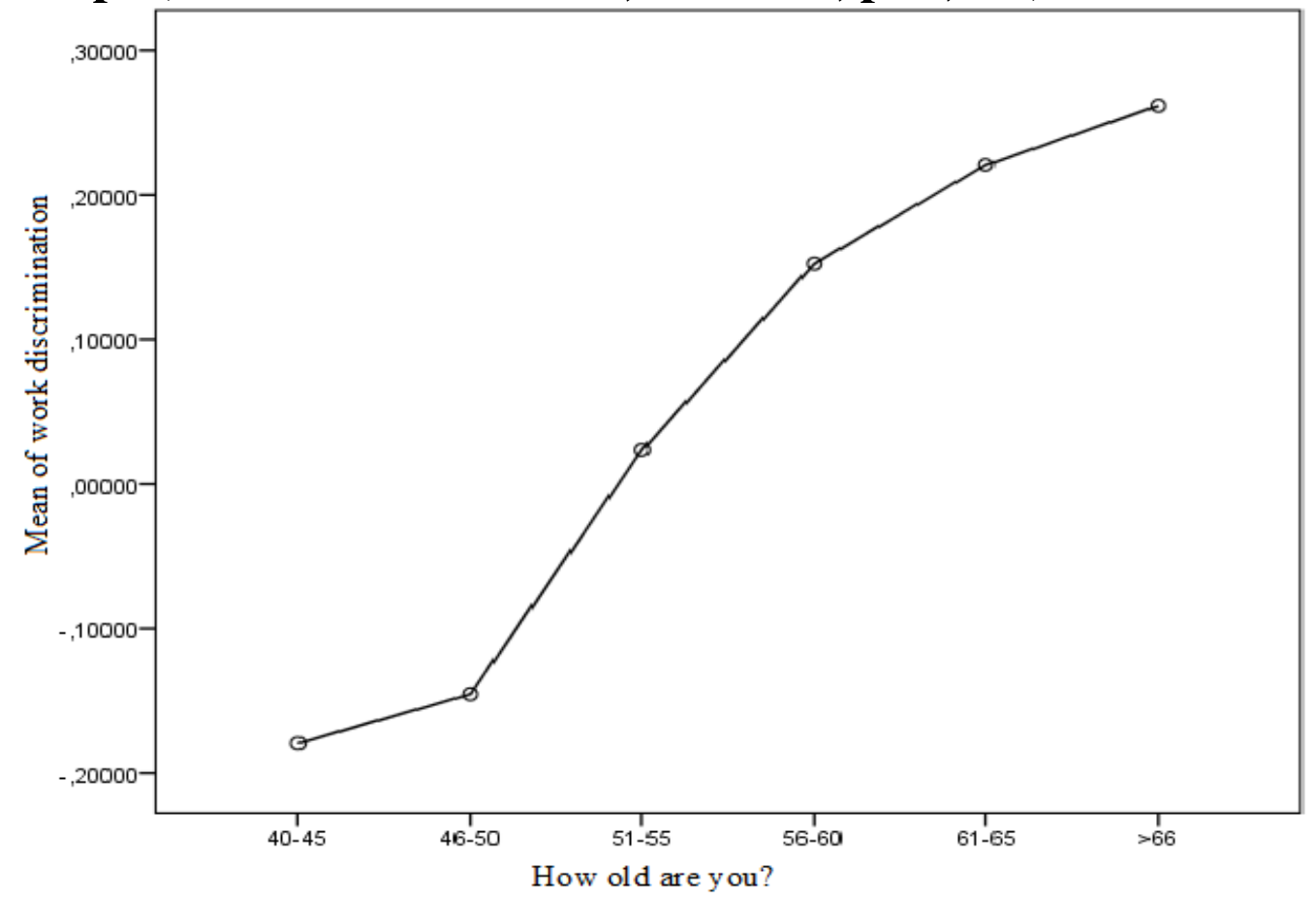

Source: Own elaboration. 


\section{Figure 2 Workplace Discrimination Index Z Scale, Comparison of Averages, $N=747$}

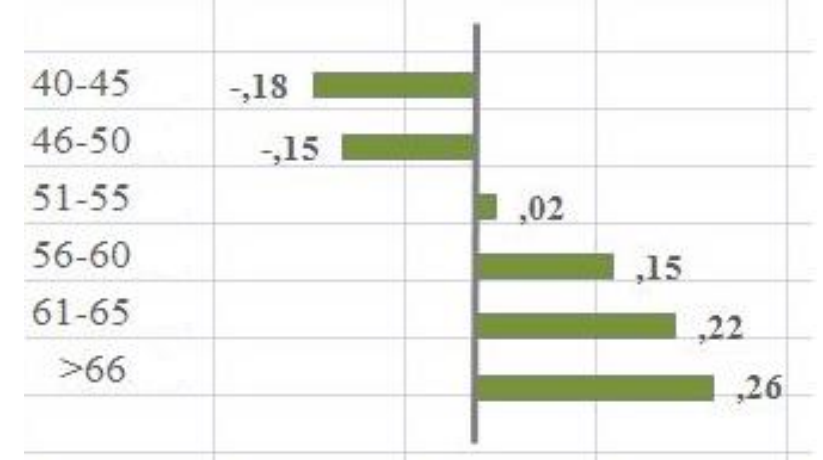

Source: Own elaboration.

The data analysis revealed that workplace discrimination is increasing with age, e.g., in the older age group, the discrimination is more intensive $(\mathrm{p}=0.007)$ (Figure 1$)$. This is also confirmed by the joint workplace discrimination index $\mathrm{Z}$ estimate averages comparison in different age groups (Figure 2).

For the analysis of differences of discrimination in various age groups, was carried out workplace discrimination scale transformation into z-scale, e.g., created scale which average equals 0 and standard deviation-1, measurement unit-one standard deviation. Differences between groups measured by evaluating them by standard deviation parts. It should be noted that negative z-scale values showing a lower level of discrimination than sample average, and positive - the opposite the lower level of discrimination than sample average. Differences of average in z-scale is one of the effect size measurement methods and can be interpreted according to Cohen (1988) proposed and in applied statistical research broadly applied scale: less than 0,2differences cannot be interpreted, 0,2-0,3-differences small, 0,30,8 -average differences and more than 0,8-differences large. The data analysis revealed that in the 40-50 years old age group the discrimination is relatively low, e.g., lower than a sample average. However, the more expressed discrimination is observed in 56-60 years old group and is increasing in older age groups (Figure 2). By comparing the expression of discrimination between women and men there, no significant statistical differences observed. 
For the comparison of expression of workplace discriminations in different age groups according to the various criteria, Kruskal-Wallis test was applied, allowing to compare more than two groups independent sample mean differences. The expression of discrimination according to the different features was compared in 6 age categories. Comparing the expression of age workplace discrimination according to the separate characteristics (see Table 2) revealed that 9 out of 14 features of discrimination is statistically significantly associated with the age, e.g., older age respondents at work more often exposed to various forms of discrimination.

Research results revealed, that older worker facing working conditions with fewer opportunities for career and advancement, e.g., they are facing restricted skills training or learning opportunities at work $(p=0,000)$, restricted promotion at work opportunities $(p=0,000), \quad$ also limited self-expression possibilities - older respondents more often facing fewer tasks, restricted functions, responsibility $(p=0,009)$. It was also noted that older workers are more exposed to discriminatory, lacking social justice and respect labor relations: the allocation of tasks, shifts, etc. often does not take into account their needs $(p=0,040)$, and they paid a lower salary for the same job compared to the others $(p=0,004)$, they have often heard against them jokes or comments $(p=0,001)$, they less likely to receive recognition or evaluation for a well done job $(\mathrm{p}=0,001)$. The study has also revealed the extreme and discriminatory behavior forms towards older age respondents. For example, older age respondents more often experienced pressure to leave workplace $(p=0,000)$, for facing dismissal from the workplace $(p=0,009)$ groundlessly. 


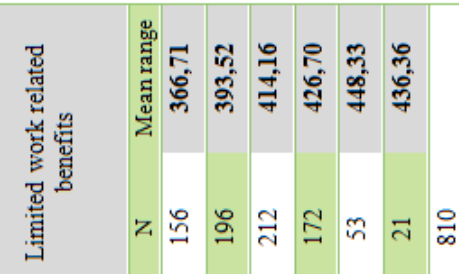

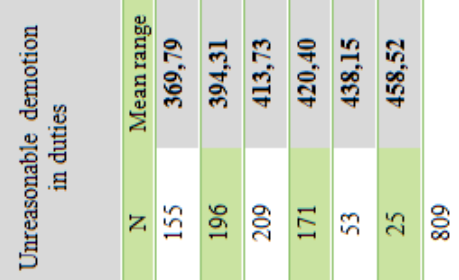

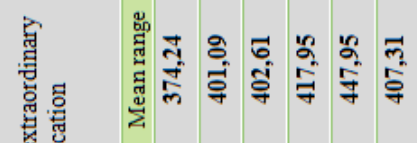

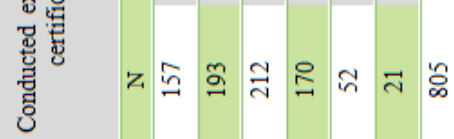

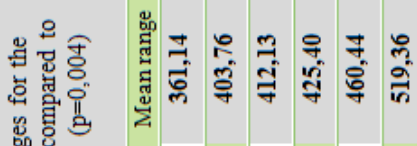

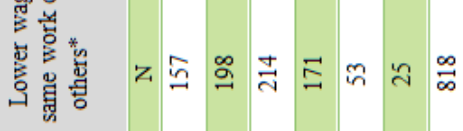

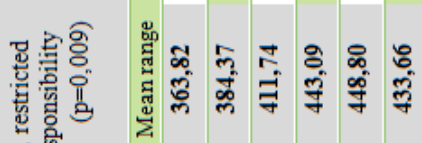

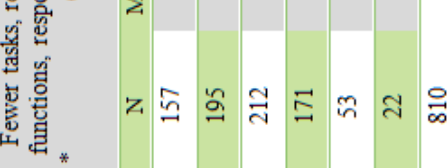

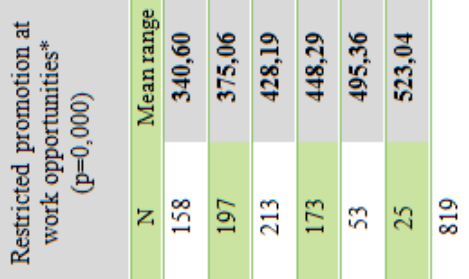

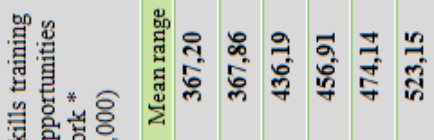

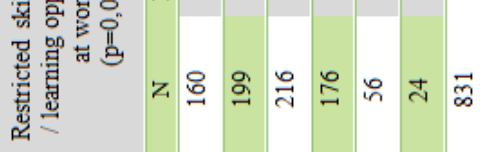

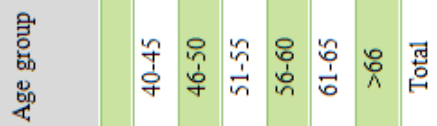

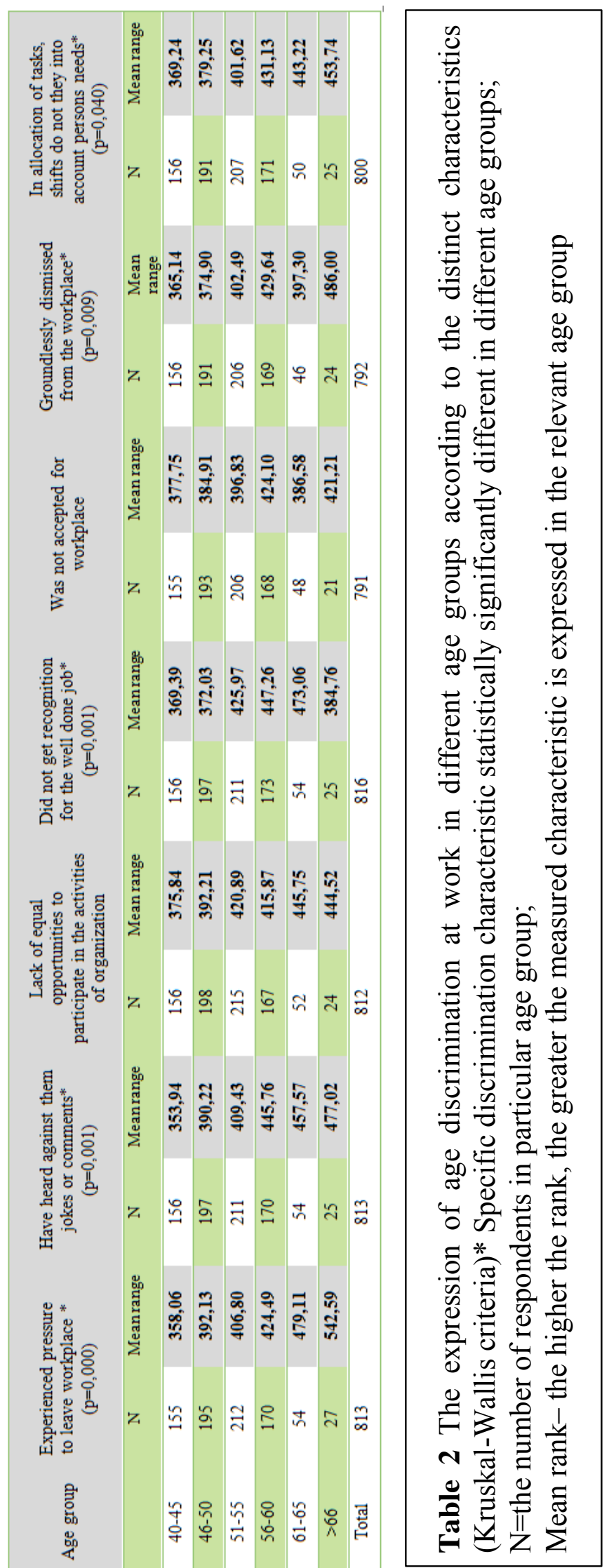


By comparing workplace discrimination according to the gender, there are no statically significant differences. Direct age discrimination in different age groups was evaluated by using crosstabs. One of the data relevance conditions for this method is then in one column of the table not less than 5 cases. This condition was satisfied in the survey. Direct discrimination was measured by asking the respondents if they are during the last five years have heard an expression "You are too old for this work"? Seven discrimination agents were indicated (persons or groups) (see Table 3).

Table 3 Expression of Age Discrimination in Different Age Groups (Crosstabs), $\chi^{2}$ )

\begin{tabular}{|c|c|c|c|c|c|c|c|}
\hline \multirow[b]{2}{*}{$\begin{array}{l}\text { Age } \\
\text { gro } \\
\text { up }\end{array}$} & \multicolumn{7}{|c|}{ D i s c r i m i nation a g e $n$ t $s$} \\
\hline & $\begin{array}{c}\text { Emplo } \\
\text { yer } * \\
(p=0,0 \\
00)\end{array}$ & $\begin{array}{c}\text { Potent } \\
\text { ial } \\
\text { emplo } \\
\text { yer }\end{array}$ & $\begin{array}{c}\text { Co- } \\
\text { worker } \\
\mathbf{s}^{*} \\
\left(\begin{array}{c}p=0,0 \\
00)\end{array}\right.\end{array}$ & $\begin{array}{c}\text { Employ } \\
\text { ment } \\
\text { agencies } \\
\text { staff }\end{array}$ & $\begin{array}{c}\text { Public } \\
\text { sector } \\
\text { (health, } \\
\text { educati } \\
\text { on, } \\
\text { social } \\
\text { service } \\
\text { s etc.) } \\
\text { staff } * \\
(p=0,0 \\
01)\end{array}$ & $\begin{array}{c}\text { Family } \\
\text { membe } \\
\text { rs* } \\
(p=0,0 \\
04)\end{array}$ & $\begin{array}{l}\text { Frien } \\
\text { ds, } \\
\text { relati } \\
\text { ves }\end{array}$ \\
\hline $\begin{array}{c}40- \\
45\end{array}$ & $0,0 \%$ & $6,3 \%$ & $1,9 \%$ & $5,2 \%$ & $1,3 \%$ & $2,5 \%$ & $3,9 \%$ \\
\hline $\begin{array}{c}46- \\
50\end{array}$ & $2,5 \%$ & $10,6 \%$ & $3,5 \%$ & $6,3 \%$ & $8,5 \%$ & $6,6 \%$ & $8,1 \%$ \\
\hline $\begin{array}{c}51- \\
55\end{array}$ & $5,0 \%$ & $6,2 \%$ & $4,2 \%$ & $6,2 \%$ & $4,8 \%$ & $6,0 \%$ & $7,4 \%$ \\
\hline $\begin{array}{c}56- \\
60\end{array}$ & $7,7 \%$ & $11,0 \%$ & $14,5 \%$ & $9,8 \%$ & $7,5 \%$ & $8,5 \%$ & $9,7 \%$ \\
\hline $\begin{array}{c}61- \\
65\end{array}$ & $14,3 \%$ & $2,4 \%$ & $28,3 \%$ & $7,5 \%$ & $15,2 \%$ & $14,0 \%$ & $\begin{array}{c}11,8 \\
\%\end{array}$ \\
\hline$>66$ & $33,3 \%$ & $17,6 \%$ & $17,4 \%$ & $0,0 \%$ & $20,0 \%$ & $21,7 \%$ & $8,7 \%$ \\
\hline
\end{tabular}

*Statistically significant age discrimination Source: Own elaboration.

The survey data revealed that direct discrimination is related to age in several groups: more likely to indicate directly that they 
are "too old" to work, employers ( $p=0,000)$, coworkers $(p=0,000)$, public sector staff $(p=0,001)$ and family members $(p=0,004)$. Even one in three over the age of 65 years old persons mentioned that suffered direct discrimination in the workplace from their employer; every fifth did not receive support from their family members (for more detailed see Table 3).

\section{Conclusion}

Analysis of scientific literature and quantitative survey data allows saying that older adults are facing different forms of discrimination because of their age. Based on the survey research results every fourth older adult is facing discrimination at work. This limits their successful integration into the labor market. Research results revealed that workplace discrimination is increasing with the age of the respondents, e.g., in the older age group expression of discrimination is higher. Age discrimination in the age group 40-50 is lower than sample average. Age discrimination is becoming more evident in the age group 56-60 and is especially increasing for older age groups. Older age is not a single factor restricting older people employment opportunities. Every third respondent indicated that he or she lacks, e.g., necessary professional qualification and work experience. Research results revealed that older workers are facing obstacles for a career, they have limited possibilities for professional improvement, learning, or training; promotion, e.g., limited qualification or training possibilities, promotion, functions, and responsibilities. Also, older workers more often facing discriminatory, lacking social justice and respect working conditions, experiencing pressure to leave the job or intentionally. Directly to discriminate against older people because of age, saying that they are "too old" is more likely to employers and coworkers, not the public-sector employees and family members.

There is a lack of appropriate measures for the successful labor market participation of older persons. In most of the cases, older workers were often not considered as a priority group. In order to decrease a discrimination of older workers, different policy measures should be applied more effectively: partial retirement schemes, age management policies at the company 
level, providing better opportunities for small business and training for older workers.

\section{References}

Alpass, F., \& Mortimer, R. (2007). Ageing Workforces and Ageing Occupations: A Discussion Paper. Wellington: New Zealand Department of Labour.

Arrowsmith, J. (2003). Theories and the Practice of Age Discrimination: Evidence from Personnel Managers. Review of Employment Topics, 6(1), 1-54.

Burns, J. (2001). Literature Review on Mature Workers Programme. Wellington: Top Drawer Consultants for Department of Work and Income.

Cohen, J. (1988). Statistical Power Analysis for the Behavioral Sciences (2nd Edition). New Jersey: Lawrence Erlbaum Associates.

Constitution of Lithuanian Republic. (1992). Retrieved from www3.lrs.lt/home/Konstitucija/Konstitucija.htm

Davey, J. A. (2007). Maximizing the Potential of Older Workers. Wellington: New Zealand Institute for Research on Ageing, School of Government, Victoria University of Wellington.

Eurobarometer. (2012a). Active Ageing. Special Eurobarometer 378 / Wave EB76.2-TNS Opinion \& Social.

Eurobarometer. (2012b). Discrimination in the EU in 2012. Special Eurobarometer 393 / Wave EB77.4-TNS Opinion \& Social.

Eurostat. (2012). Active Ageing and Solidarity Between Generations:

A Statistical Portrait of the European Union. Luxembourg:

Publications Office of the European Union.

Gray, L., \& McGregor, J. (2003). Human Resource Development and Older Workers: Stereotypes in New Zealand. Asia Pacific Journal of Human Resources, 3(41), 338-353.

Gruber, J., \& Wise, D. A. (2004). Social Security Programs and

Retirement around the World: Micro-Estimation. Chicago:

University of Chicago Press.

Gruzevskis, B., Okuneviciute-Neverauskiene, L., \& Biveinyte, S. (2006). Sunkiai integruojamu asmenu padèties darbo rinkoje analizè ir priemonès jų užimtumui didinti [Integration of persons experiencing difficulties on the labor market and measures for 
increasing their employment]. Vilnius: Labour Market Research Institute.

Hardy, M. A. (2011). Rethinking Retirement. In J. R. A. Settersten \& J. L. Angel (Eds.), Handbook of Sociology of Aging (pp. 213328). New York, NY: Springer Science+Business Media, LLC. Laczkó, F., \& Phillipson, C. (1991). Changing Work and Retirement: Social Policy and the Older Worker. Buckinghamshire: Open University Press, Milton Keynes.

Lazutka, R., \& Skuciene, D. (2005). Pagyvenusių asmenų užimtumas [Employment of older persons]. In R. Lazutka, A. V. Matulionis, \& V. Stankūnienè (Eds.), Lietuva Europos Sajungoje Pirmieji metai [Lithuania in the European Union: first years] (pp. 117128). Vilnius: Social Research Institute.

Lithuanian Labour Code. (2002). Retrieved from https://eseimas.lrs.lt/portal/legalAct/lt/TAD/TAIS.169334

McMullin, J. A., Cooke, M., \& Downie, R. (2004). Labour Force Ageing and Skill Shortages in Canada and Ontario: Research Report. Retrieved from http://cprn.org/documents/31517_fr.pdf

Mikulionienè, S. (2008). Diskriminacijos dèl amžiaus samprata viešajame diskurse: Asmenų, dirbančių viešajame sektoriuje, atvejis [Perception of age discrimination: the case of public servants]. Socialinis darbas. (7 (1)), 19-25.

National Program on Equal Opportunities for Women and Men for 2015-2021. (2015). Retrieved from www.etar.1t/portal/lt/legalAct/dc012450b1 ca11e48296d11f563abfb0 Okunevičiūtè-Neverauskienè, L. (2011). Diskriminacijos apraiškos: Aktuali būklè bei tendencijos antidiskriminacijos srityje [Manifestation of discrimination: actual situation and trends in the field of anti-discrimination in Lithuania]. Filosofija. Sociologija. (22 (2)), 115-128.

Okunevičiūtė-Neverauskienė, L., \& Moskvina, J. (2007). Vyresnio amžiaus Lietuvos gyventojų profesinio mokymo ir konsultavimo poreikiai [The need of professional teaching and counselling in older adults of Lithuania]. Gerontologija. (4 (8)), 236-245.

Okunevičiūtè-Neverauskienė, L., \& Moskvina, J. (2008). Vyresnio amžiaus asmenų dalyvavimo darbo rinkoje galimybių vertinimas [Evaluation of older person possibilities in the Lithuanian labor market]. Socialinis darbas. (7 (1)), 26-35. 
Raškinis, D. (2008). Lietuvos darbo rinka: Problemos ir galimi sprendimo būdai [Lithuanian labor market: problems and possible solutions]. Taikomoji ekonomika. (2 (1)), 55-71.

Riach, P. A., \& Rich, J. (2007). An Experimental Investigation of Age Discrimination in the English Labor Market: Discussion Paper No. 3029. IZA DP No. 3029. Bonn. Retrieved from http://ftp.iza.org/dp3029.pdf

Sargeant, M. (2011). Age Discrimination: Ageism in Employment and Service. Farnham: Gower Publishing Limited.

Sterns, H. L., \& Miklos, S. M. (1995). The Aging Worker in a Changing Environment: Organizational and Individual Issues. Journal of Vocational Behavior, 47(3), 248-268.

The Law on Equal Opportunities for Women and Men. (2016). Retrieved from www3.lrs.lt/pls/inter3/dokpaieska.showdoc_1?p_id=276095

The Law on Equal Treatment 2005. (2005). Retrieved from www3.lrs.1t/pls/inter3/dokpaieska.showdoc_1?p_id=222522\&p_ query $=\& p \_$tr $2=$

The Law on Support on Employment. (2016). Retrieved from www.etar.lt/portal/lt/legalAct/422c8b5042b811e6a8ae9e1795984391

UK Commission for Employment and Skills (UKCES). (2011). Older People and Skills in a Changing Economy: Briefing Paper Series. Retrieved from www.oph.fi/download/140969_equalityolder-people.pdf

Walker, A. (1993). Age and Attitudes. Brussels: European Commission.

Walker, A. (2005). The Emergence of Age Management in Europe. International Journal of Organizational Behaviour, 10(1), 685697. 
Suggested Citation: Leszko, M., \& Bugajska, B. (2017). The Evaluation of Employment Policies for Older Adults in the Czech Republic, Poland, and Slovakia. In Ł. Tomczyk \& A. Klimczuk (Eds.), Selected Contemporary Challenges of Ageing Policy (69-87). Kraków: Uniwersytet Pedagogiczny w Krakowie. Doi: 10.24917/9788380840911.4

\section{MAGDALENA LESZKO ${ }^{1}$}

\section{BEATA BUGAJSKA ${ }^{2}$ \\ The Evaluation of Employment Policies for Older Adults in the Czech Republic, Poland, and Slovakia}

Abstract: Adults aged 65 and above comprise the fastest growing sector of the world's population. In the context of increasing numbers of older adults, employment policies have become a prominent issue. Governments recognize the importance of increasing participation in working age population and providing them with equal workplace opportunities. Yet, it appears that policies raising employment rates of older adults have become a slogan that governments use for election purposes, but the reality is different. In the groundbreaking report "Working Better with Age: Poland" prepared by the Organization for Economic Cooperation and Development (OECD) (2015), Poland, the Czech Republic, and Slovakia belong to a group of countries where the increase in the employment rate of older adults is well below the OECD average. The objective of our critical review is to evaluate current employment policies for older adults, including but not

\footnotetext{
${ }^{1}$ Magdalena Leszko, Department of Medical Social Sciences, Northwestern University, Chicago, IL, USA, leszkomagda@gmail.com.

${ }^{2}$ Beata Bugajska, Department of Social Pedagogy, University of Szczecin, Poland, beata.bugajska@usz.edu.pl.
} 
limited to healthy work conditions, age management strategies, employment services for older workers, and strategies implemented to prevent age discrimination, in these three countries. This article also discusses the reasons for the reduction in the employment of older adults, the current barriers in employing older adults that require governments' attention, and suggests solutions for creating an age-friendly labor market that can effectively make use of older adults' competencies. Employment rates for people of different ages are significantly affected by government policies with regard to higher education, pensions, and retirement age.

Key words: Age Management, Employment Policies, Protection Programs

\section{Introduction}

In light of a steady increase in the older population, emigration of young people, and declining fertility rates, concerns about the increasing economic burden brought about national efforts to focus on issues of employment policies and retirement-income systems. The population of older adults ( 65 years old and older) in the Czech Republic in 2014 represented $17.4 \%$ of the population, $13.5 \%$ in Slovakia, and $14.7 \%$ in Poland (Eurostat, 2015a). While the percentage of older adults in the total population is projected to increase in some European countries during the period between 2014 and 2080 by the average of $10 \%$ points, some countries will experience a more rapid increase in the share of the older adults population. For example, the fraction of the population of Slovakia aged 65 and older will increase by $22 \%$ by 2080 . Over the same period, Slovakia will experience a significant decrease in the total number of inhabitants of around $30 \%$ (Eurostat, 2015b).

There are several economic and social implications arousing from a rapid ageing of the population and a longer life expectancy. One of the most apparent economic implications is the sharp rise in the old age dependency ratio that will occur within the next 30 years (Gavrilov \& Heuveline, 2003). For example, in the Czech Republic the current old age dependency ratio of those aged 65 and above to working population between 15 and 64 years is 25.7 
individuals for every 100 workers (i.e., individuals 65 and older constitute almost $26 \%$ of working-age population). In Slovakia, the age dependency ratio is 19.0, which is relatively low in comparison to other European countries. In Poland, the old age dependency ratio is 22.0. However, based on Eurostat's population projections, by 2050 both Slovakia and Poland will experience the biggest rise of the old age dependency ratio ranging from 35 to 50 percentage points. In other words, it is estimated that in a few decades there will less than two working-age persons for each person aged 65 or more (Eurostat, 2015b).

Other consequences of the ageing workforce include rising social security costs and having to pay higher taxes to support more retirees (Silverstein, 2008). The significant shift in the age structure can have detrimental effects on economic growth and negatively impact the sustainability of government entitlement programs. In addition, it can lead to labor and skills shortages in the future (Błaszczyk, 2016). The potential effects of an ageing population have been widely acknowledged by policy and decision-makers. In addition, a number of studies tried to predict the effects of ageing on retirement policies, use of long-term care services, and the workforce composition (e.g., Maestas, Mullen, \& Powell, 2016; United Nations, 2015; Zweifel, Felder, \& Meiers, 1999). However, it seems that most countries are not prepared to meet the challenges associated with an increasing number of older adults reaching the retirement age.

The above-mentioned consequences of demographic change underscore the need to reshape employment and retirement policies. In response to the demographic projections, the European Union (EU) countries have been trying to maintain or encourage older workers to remain employed by pension reforms and active labor market policies. To facilitate the process, in 2000 the EU launched a Lisbon Strategy. This strategy aimed at, among others, increasing the average EU employment rate among older women and men aged 55 to 64 to $50 \%$ by 2010 (Moraal \& Schönfeld, 2006). The goal was reached only in six of the EU member countries: Cyprus, Denmark, Estonia, Portugal, Sweden, and the United Kingdom. Perhaps objectives outlined in the Lisbon Strategy were not met due to the economic crisis that hit Europe 
and had profound effects on Europe's economy (European Commission, 2010). Nevertheless, the EU realizes the importance of successful integration of older workers into the workforce and is determined to achieve the goal of an employment rate for people aged 55-64 of 50\% by 2020 (OECD, 2016).

This paper begins with an introductory section providing background information on the current employment rates of older adults in the Czech Republic, Poland, and Slovakia. The next paragraph describes the possible factors that contribute to the low rates of employment. In the following paragraphs, we discuss the changes to retirement systems and programs, which overreaching goal is to improve the current situation of older adults in the labor market. The paper concludes what steps should be taken to eliminate discrimination against older workers, who should be encouraged to participate in or continue with labor market activities. The evaluation of employment policies for older adults in the Czech Republic, Poland and Slovakia seems to be particularly important because all of these countries underwent successful political and economic transitions, which began in 1989 and has brought several significant changes to their demographic structure, economic development, quality of life, and public policies. Taking into account that Poland and Slovakia have one of the lowest levels of employment of older adults in the EU, it has become more crucial to examine public policies that aim at increasing the employment rates.

Older people are generally defined as being 65 years old or older (WHO, 2010) but in this chapter, we focus on individuals aged 55 and over as their share has increased significantly over the past decades and is projected to increase even further in the years to come (Eurostat, 2015b). Most of the government initiatives for older workers also aim at people aged 55 and more (Błaszczyk, 2016; Grotkowska, 2013).

\section{Current Employment Rates Among Older Adults in the Czech Republic, Poland, and Slovakia}

Older workers are a significant and growing part of the workforce. The Czech Republic, Poland, and Slovakia have witnessed changes in their labor market in recent decades. In Poland, the rate 
of employment among individuals 55-59 has grown significantly from $37.7 \%$ in 2004 to $45.8 \%$ in 2010 , yet it was the lowest in Europe. The Czech Republic experienced even higher increase, from $59.1 \%$ in 2004 to $76.9 \%$ in 2014 . The highest increase in labor force participation of individuals aged 55-59 was observed in Slovakia, where the rate increased from $34.5 \%$ in 2004 to $57.9 \%$ in 2014 (Národný Program Aktívneho Starnutia na roku 2014-2020; OECD, 2014). Despite a strong increase in each of the above-mentioned countries, the participation in labor was still low. In comparison with other European countries, in 2010 over $80 \%$ of Swedish and $75.9 \%$ of Danish population of individuals aged 5559 were employed. The average employment rate across all Organization for Economic Cooperation and Development (OECD) countries was equal to 67\%. (Eurostat, 2015b).

The employment rate for individuals aged 60-64 in both the Czech Republic and Poland rose steadily from 2004 to 2014, from $20.7 \%$ to $32.2 \%$ and from $18.2 \%$ to $26.3 \%$, respectively. The employment rates in Slovakia for individuals aged 60-64 also increased from $6.1 \%$ in 2004 to $17.2 \%$ in 2014. However, Slovakia and Hungary had the lowest rates of employment in this age group (13.0\%) whereas Sweden and the United Kingdom were among the countries with the highest rates of employment $(61.0 \%$ and $44.0 \%$ respectively). Although the employment rates improved among those, who are 55 and above, employment rates among individuals aged 65 and older (retirees having reached statutory pension age of 65 years) in the Czech Republic, Poland, and Slovakia were fairly low. For those aged 65 and over, the highest employment rates were found in Portugal $(16.5 \%)$ and Romania (13.0\%) and the lowest in France and Slovakia (both 1.6\%). The Czech Republic experienced a slight increase from $7.9 \%$ in 2004 to $9.1 \%$ ten years later. Interestingly, there was a slight drop in the rate of employment in Poland. The data revealed that in 2004, 10.4\% of those who were 65 and above were employed whereas in 2014 only $9.7 \%$ had a job. In comparison, the OECD average was $20.2 \%$. The growth in employment for older adults in the Czech Republic, Poland, and Slovakia can be attributed to entering the EU (Bednárik \& Škorpík, 2007). 


\section{Barriers to Employment of Older Adults}

Although the employment rates improved, the current low employment rates in the Czech Republic, Poland, and Slovakia are alarming. The reasons are complex, and a lot of factors contributed to the current situation. Research shows that the relationship between age and underemployment is non-linear meaning that young people and older adults have higher chances of being underemployed (Jensen \& Slack, 2003). A number of authors point out that older adults are at a disadvantage in the labor market and that barriers are still prevalent (Bednárik \& Škorpík, 2007; Cory, 2012; Radović-Marković, 2013; Szukalski, 2014). Therefore, even though the majority of older people want to work past state pension age (Cory, 2012), they are confronted with difficult to overcome obstacles. One of the most common employment barriers for older adults is their health status. Older adults are at risk for multiple, comorbid chronic health conditions because they become more common with age (Barile et al., 2012). Chronic health conditions such as cancer, dementia, cardiovascular disease (primarily stroke and heart disease), and diabetes are among the leading causes of adult mortality and disability among older adults (Mackay \& Mensah, 2004). These conditions may affect older adults' physical and mental health (Anderson, Freedland, Clouse, \& Lustman, 2001; Miller et al., 2008) and may cause worse physical functioning (Boult, Kane, Louis, Boult, \& McCaffrey, 1994). In addition, sensory impairments such as vision and hearing loss are associated with ageing (Saunders \& Echt, 2007). It is, therefore, likely that both vision and hearing loss and other chronic health conditions negatively influence individuals' ability to perform job responsibilities.

Disability is also one of the main causes of nonworking. Due to various diseases or health conditions, often arising from working in hazardous conditions, many older adults suffer from a disability that significantly limits their ability to work. According to data from the Central Statistical Office (CSO), the disabled population in Poland consists mainly of older adults. Individuals aged 55 to 64 years constituted $32.3 \%$ of the total disabled population whereas individuals 65 years and more constituted 
$33.7 \%$ (CSO, 2012). In order to improve the employment situation of older adults in Poland, the Act of 27 on Vocational and Social Rehabilitation and Employment of Persons with Disabilities (Ustawa o rehabilitacji zawodowej i społecznej oraz zatrudnianiu osób niepełnosprawnych) was introduced in 1997. Yet, people with disabilities still perceive their work opportunities as very limited (CSO, 2012) and the labor market situation of this group continues to get worse. This can be partly explained by too little support offered from the public policy to hire disabled individuals and partial disability pension, which discourages individuals from working (Kuciński, 2012). Older adults in the Czech Republic are also allowed to exit the labor market, even though they did not reach the legal minimum retirement age, by receiving a disability pension. However, the government introduced changes to the system in 1995 which tightened the eligibility for disability and resulted in a significant switch from full to partial disability pensions in many cases (Bednárik \& Škorpík, 2007).

The relatively low level of education and insufficient level of training among older adults also play a significant role as a barrier to employment (Kuciński, 2012). Due to a rapid and constant transition of the labor market, older adults need to acquire new skills, which for many older adults is perceived as challenging. Data shows that Poland has a relatively low education level among older adults (Błaszczyk, 2016). Only 16\% of the age group 55-64 had completed bachelor's degree level, whereas OECD average is $27 \%(\mathrm{OECD}, 2015)$. Another problem is the inadequate training in information and communications technology. In the group of individuals aged 55-64 years, in 2010 only $30 \%$ of Poles used the Internet, which is $18 \%$ lower than the EU average (Batorski, 2009). Lack of formal education and outdated skills are the main reasons that explain not only why so many older adults are unemployed but also why it also takes them twice as long as the overall population to find a new job (RadovicMarkovic, 2013).

Discrimination against older workers is also a significant and long-standing issue. Age discrimination occurs when preferential decisions are based on age, rather than on employee's merits, credentials, or job performance (Radovic-Markovic, 2013). 
Age discrimination is often based on stereotypes and myths about their poor mental and physical health and decreased productivity (Carstensen \& Hartel, 2006). These beliefs are predominant, even though research shows that older adults are experienced, and employees' performance depends on the type of tasks carried out (Marcinek, 2007). Employers are reluctant to hire older adults because they judge them as being resistant to change, lacking creativity, being prone to accidents, disinterested in new technologies, and slow to learn (Błaszczyk, 2016). These stereotypes result in various kinds of discrimination including hiring, limited career development, poor job assignments, and little respect for the knowledge gained through experience (North \& Fiske, 2012).

\section{Current Retirement Policies in Poland, the Czech Republic, and Slovakia}

Considering the relatively low incidence of work participation among older adults, being unemployed makes an increasingly important social issue. This burden comes in the form of lost productivity and tax revenue, as well as a very substantial rise in public expenditure on entitlements to support older people after retirement. The current growth rate of older people underscores this issue as the baby boom generation moves gradually towards retirement age. The economic burden of an ageing population depends on public policies and the employment decisions of older adults. If workers continue to retire at relatively young age and if the current retirement policies allow them to do so, then the ageing of the baby boomers will decrease the number of people in the workforce, who pay taxes for every older person collecting retirement and health benefits. The process of increasing the statutory retirement age is a reaction to the process of demographic changes in society, especially regarding longevity. This process also helps maintain older people in the labor market and has been the main factor in the variations in the employment rates. To mitigate this burden, the Czech Republic, Poland, and Slovakia introduced the process of the gradual increasing of statutory retirement ages both for men and women. However, the government of Poland has recently revised the retirement policy 
and lowered the retirement age to 60 years for women and 65 years for men (Ministry of Family, Labour, and Social Policy, 2016). This was due to the fact that the conservative Law and Justice party, whose lowering the retirement age was one of the key electoral promises, was able to win the general election.

\section{The Czech Republic}

Until 1995, the statutory retirement age had been 60 for men and 53-57 for women (depending on the number of children). Then, the 1995 New Pension Insurance Act introduced the process of the gradual increase of statutory retirement age both for men and women (Bednárik \& Škorpík, 2007). While the retirement age for men was increased to 63 years old, women's retirement age depends on the number of children. Having raised two children reduces retirement age by one year, three children by two years, and four or more children by three years. Therefore, women can retire at the age of 59-63 (Bednárik \& Škorpík, 2007; Hála, 2013). Although it is still possible to retire three years before retiring, the new retirement system discourages early retirement by a significant decrease in pension income. On the contrary, the retirement reform in the Czech Republic created the encouragement to work after reaching the retirement age and offers three possibilities to do so. Older adults can postpone receiving a pension which will result in its increase in the future. Another option is to retire partially which means receiving $50 \%$ of the pension throughout this period and continuing working parttime. The third option is to reach the statutory retirement age and continuing to work (Grotkowska, 2013).

\section{Poland}

The Polish government decided to introduce changes to the pension system in order to balance economic growth by postponing retirement. The reform of the pension system, which entered into force on January 1st, 1999, modified the Polish payas-you-go (PAYG) pension system into the system individualizing the participation. In the new system, the pension amount depends on the means gathered on the individual account during the whole professional career and the expected life length at the moment of 
retiring. The postponement of retiring results in the increase of benefit, so the new system rewards extended the professional activity. The new system obligatorily includes people born after 1968 , so the motivational system will influence the decisions of people retiring after 2032. The second important element of the pension reform was the significant limitation of possibility to retire early by introducing the so-called "bridging pensions." The right to receive the bridging pension has the insured employee who meets all the following conditions: 1) was born after December 31 st, 1948; 2) is at least 55 years of age for women and at least 60 years for men; 3) has a work period in adverse conditions or specific character of at least 15 years; and 4) has a contributory or noncontributory period of at least 20 years for women and at least 25 years for men. As a result of this legislation, a big group of people working in special conditions lost right to retire early. It is also important that the bridging pension system was created as an expiring system because it does not include people who began their professional career after December 31st, 1998. The third element of the reform of the pension system is increasing the retirement age. From January 1st, 2013, the retirement age in Poland has been increased by a month in January, May, and September each year until it reaches 67 for both sexes, not until 2040 for women and for men in 2020. However, in 2016 the implemented reform was changed. The government of Poland decided to stop the process of gradually raising the retirement age to 67 for both sexes and starting from October of 2017 it allows women to retire at the age of 60 and men at 65 (Ministry of Family, Labour, and Social Policy, 2016). Lowering the retirement age was confronted with a wave of criticism from economists and gerontologists who question the country's financial sustainability. Hopefully, the government will introduce some incentives that will encourage people to work longer.

\section{Slovakia}

In 2005 Slovakia underwent a major pension reform, and the current pension system consists of three independent elements, i.e., three pillars. An individual can receive an old-age pension 
from the mandatory pension insurance (the first pillar) or old-age pension saving (the second pillar). The system also allows individuals to accumulate additional savings on a voluntary basis (third pillar), on top of the statutory old-age social security contributions into the first and second pillars. Similarly, to the Czech Republic, the extension of the retirement age in Slovakia is related to adverse demographic trends. Since 2017, the retirement age will rise about 50 days per year. Currently, the retirement age is 62 years old for women and 65 years old for men with at least 15 years of contributions and has been gradually introduced over a period from 2004 to 2014: for men born after 1946, and for women born after 1962 (Šoltés \& Modráková, 2013). As in the Czech Republic, a woman with children is eligible to retire earlier than a childless woman.

\section{Public Policies and Protection Programs}

As the population ages, the need for government to encourage the employers to hire individuals aged 55 and above becomes crucial. Apart from increasing the statutory retirement age, the governments of the Czech Republic and Slovakia adopted programs that increase opportunities for older people to have longer working lives and meet the EU's goal of the employment rate of 50\% among individuals aged 55-59.

\section{The Czech Republic}

In order to increase labor force participation of older adults, the Czech Republic introduced a reform of the pension system and implemented government projects aimed at the age group of individuals 55-59. One of the most important changes are adjustments in the tax system. The "National Strategy of Promoting the Active Growing Old for the years 2013-2017" developed by the Ministry of Labour and Social Affairs assumes the introduction of taxation of the national pension unless the taxpayer earns money at the same time (Ministry of Labour and Social Affairs of the Czech Republic, 2014). On the other hand, the unemployed pensioners would not have to pay the tax from the pension. In this case, it is worthier to postpone the retirement until the termination of the gainful employment. The Czech Republic 
also initiated other projects aiming at professional activation of older adults. In the "National Strategy of Promoting the Active Growing Old for the years 2013-2017," the government proposed actions promoting the implementation of age management by the employers. The government also considers introducing the financial encouragements for the companies taking part in the promotion campaign of using the flexible forms of work adjusted to the employees' needs. One of the offered strategic aims is to propose the unemployed of 50+ years of age to start their own businesses and provide them with necessary support (Grotkowska, 2013).

\section{Poland}

In 2008, the government introduced the program "Solidarity Across Generations" which aims at increasing incentives for companies to employ individuals aged 50 and above and promotes access to employment during the whole period of working life (Marczewski, 2013). Other initiatives include the protection period for employees in the pre-retirement age-since 2004 the employer cannot terminate the employment contract of the employer who lacks no more than four years to reach the retirement age if the period of employment allows him to gain the right to retire with reaching this age. Protected are women of 56-60 years of age and men of 61-65 years of age. Before 2004, the protection period was two years. Another action taken to increase the employment rates is the exemption from paying a contribution. Since 2009 there is a possibility of a temporary and permanent exemption of the employers from paying the contributions to the Labour Fund and the Guaranteed Employment Benefits Fund for the people of the pre-retirement age. The employers do not pay those contributions in two cases: a) for the first 12 months after concluding an employment contract with a person who is over 50 years of age and a person who was registered in the unemployed database in the district labor office for at least 30 days prior to working, and b) indefinitely in case of people over 55 years of age for women and at least 60 years of age for men. 


\section{Slovakia}

A number of measures to enhance employment have been introduced in order to decrease high unemployment rates in Slovakia. The National Program for Active Ageing for the years 2014-2020 in Slovakia, as well as similar programs in the Czech Republic and Poland, provides a comprehensive understanding of the support of older adults (Ministry of Labour and Social Affairs of Slovakia, 2014). The program goes beyond employment policy, focusing on the rights of older adults, support policies, lifelong learning, and social and civic outside of the formal labor market, promoting their independence, dignity, economic security, and social development, including protection against mistreatment in all spheres of social life. The program ensures the right to employment of individuals aged 50 and more and introduces antidiscrimination policies because of their age. In addition, the National Program draws attention to the low awareness of agemanagement for not recognizing the benefits of employing older people. Among the strategic objectives in this area is, among others, to create the Committee (Council) responsible for older adults. The committee serves as an advisory body of the Slovak government. The purpose of this committee would be to adjust public policies related to ageing, in particular: a) to define the concept of age-management and the establishment of management rules in the private and public sectors and $b$ ) motivating employers (public and private sector) to use age management strategies, to promote the employment of older workers, and to motivate workers to remain in the labor market. The implemented program emphasizes the necessity of special support of individuals aged 50 and above, who remain disadvantaged in the labor market. This can be done by, for example, helping older adults in finding a job. Attention should also be given to the need of improving the safety of older workers in the workplace, with an emphasis on creating appropriate working conditions.

\section{Summary and Future Directions}

Due to an ageing population, low fertility rates, rising social security costs, many of the European countries, including the Czech Republic, Poland, and Slovakia, introduced public policy 
changes significantly affecting older adults. Such changes include, among others, raising the statutory retirement age (apart from Poland). Although increasing the retirement age seems to be inevitable, many older adults are dissatisfied, and those changes met with strong opposition from many workers. The governments of the Czech Republic and Slovakia must take into account the advantages and disadvantages of prolonging their citizens' working lives. Introducing changes that encourage people to work longer is necessary but requires adjusting the labor market to the needs and capabilities of older people. It seems that implementing the strategies used in developed countries, such as the wage subsidy and job creation, vocational guidance, lifelong learning programs, and the reintegration of the unemployed is crucial. Although the Labour Code in Poland includes the antidiscrimination provisions according to which the employees have equal rights based on performing the same duties, many older adults are not treated equally regarding concluding and terminating the employment contract, working conditions (including the salary), and promotion and access to training for improving professional qualifications. While we do realize that it is difficult to combat age barriers, it seems important to intensify activities in the field of age management, including promotion of employment among older workers and encourage employers to hire older adults by offering them certain benefits. However, little evidence is available about the effectiveness of these measures. In general, implementing all the changes may be challenging for the Czech Republic, Poland, and Slovakia since they had to cope with the effects of undergoing a major transformation in the early 1990s and do not have any experience with a rapidly ageing population.

There are certain action steps that each country can take in order to accommodate the increasing number of older workers. In order to attract and retain older workers, employers must change their workplace practices. Strategies promoting further training in companies for low-skilled and employees may benefit not only older workers but also their employers, but the government should offer some incentives for companies to invest in further training for older workers. In addition, the labor market should become 
more flexible and offer more part-time jobs for older adults. This arrangement would allow older adults to work despite their physical limitations. Although this solution would be related to a significant decrease in older adults' income, some studies have showed that even though older adults are aware of the demographic crisis as well as the fact that their income will be greatly reduced, the majority of them would like to retire before legal retirement (Andel, 2014). As the populations of the Czech Republic, Poland, and Slovakia ages and the number of people reaching retirement ages increases, additional reforms may be needed to sustain the pension system. Therefore, the governments of these countries should start working on the most effective ways to increase work participation among older adults.

\section{References}

Andel, R. (2014). Aging in the Czech Republic. The Gerontologist, 54(6), 893-900.

Anderson, G. (2004). Chronic Conditions: Making the Case for Ongoing Care. Retrieved from www.partnershipforsolutions.org/DMS/files/chronicbook2004.p df

Barile, J. P., Thompson, W. W., Zack, M. M., Krahn, G. L., HornerJohnson, W., \& Haffer, S. C. (2012). Activities of Daily Living, Chronic Medical Conditions, and Health-related Quality of Life in Older Adults. The Journal of Ambulatory Care Management, $35(4), 292-303$.

Batorski, D. (2009). Wykluczenie cyfrowe w Polsce [Digital exclusion in Poland]. In D. Grodzka (Ed.), Społeczeństwo informacyjne [Information society] (pp. 223-249). Warszawa:

Biuro Analiz Sejmowych Kancelarii Sejmu.

Bednárik, R., \& Škorpík, J. (2007). Transition from Work to Retirement in the Czech Republic and Slovakia. Retrieved from www.euro.centre.org/data/1196158698_15297.pdf

Błaszczyk, B. (2016). Sytuacja osób starszych na rynku pracy w Polsce [The situation of older adults in the labor market in Poland]. Gerontologia Polska, (24), 51-57.

Boult, C., Kane, R. L., Louis, T. A., Boult, L., \& McCaffrey, D. (1994). Chronic Conditions That Lead to Functional Limitation in the Elderly. Journal of Gerontology, 49(1), M28-M36. 
Carstensen, L. L., \& Hartel, C. R. (Eds.). (2006). When I'm 64.

Washington, DC: National Academies Press.

Central Statistical Office. (2012). Employment of Disabled People in

2011: Statistical Information and Elaboration. Retrieved from

http://stat.gov.pl/cps/rde/xbcr/gus/pw_osoby_niepelnosprawne na_rynku_pracy_w_2011.pdf

Cory, G. (2012). Unfinished Business: Barriers and Opportunities for

Older Workers. Retrieved from

www.resolutionfoundation.org/app/uploads/2014/08/Unfinished

Business_FINA 3.pdf

European Commission. (2010). Lisbon Strategy Evaluation

Document. Retrieved from

http://ec.europa.eu/europe2020/pdf/lisbon_strategy_evaluation_ en.pdf

Eurostat. (2015a). Population Age Structure by Major Age Groups, 2005 and 2015 (\% of the Total Population). Retrieved from http://ec.europa.eu/eurostat/statisticsexplained/index.php/File:Po pulation age structure by major age groups, 2005 and

015 (\%25_of the total_population)_YB16.png

Eurostat. (2015b). Employment, Social Affairs \& Inclusion:

Demography Report. Retrieved from

$\mathrm{http} / /$ ec.europa.eu/eurostat/documents/3217494/6917833/KE-

BM-15-003ENN.pdf/76dac490-9176-47bc-80d9-029e1d967af6

Gavrilov, L. A., \& Heuveline, P. (2003). Aging of Population. In P.

G. Demeny \& G. McNicoll (Eds.), Encyclopedia of Population

(pp. 32-37). Farmington Hills, Mich.: Macmillan Library

Reference.

Grotkowska, G. (2013). Analiza porównawcza zmian sytuacji osób $45+$ na rynkach pracy w Polsce oraz w wybranych krajach UE intensywnie promujących politykę zarządzania wiekiem [Comparative analysis of changes in the situation of adults aged 45 and older in the labor market in Poland and in selected EU countries which intensively promote age management policies]. Retrieved from www.parp.gov.pl/files/74/517/18983.pdf

Hála, J. (2013). Czech Republic: The Role of Governments and

Social Partners in Keeping Older Workers in the Market.

Retrieved from

www.eurofound.europa.eu/eiro/studies/tn1210012s/cz1210019q. htm 
Jensen, L., \& Slack, T. (2003). Underemployment in America:

Measurement and Evidence. American Journal of Community

Psychology, 32(1-2), 21-31.

Kuciński, M. (2012). Sytuacja osób starszych na rynku pracy w

Polsce [The situation of older adults in the labor market in

Poland]. Roczniki Ekonomiczne Kujawsko-Pomorskiej Szkoty

Wyższej w Bydgoszczy. (5), 127-148.

Mackay, J., Mensah, G. A., Mendis, S., \& Greenlund, K. (2004). The

Atlas of Heart Disease and Stroke. Geneva: World Health

Organization.

Maestas, N., Mullen, K. J., \& Powell, D. (2016). The Effect of

Population Aging on Economic Growth, the Labor Force and

Productivity. Cambridge, Mass.: National Bureau of Economic

Research. Retrieved from www.nber.org/papers/w22452

Marcinek, P. (2007). Funkcjonowanie intelektualne w okresie późnej starości [Intellectual functioning in old age]. Gerontologia Polska. (15(3)), 69-75.

Marczewski, K. (2013). The "Generations' Solidarity" Program and Its Impact on the Labour Market. Konsumpcja i rozwój. (2), 4662.

Miller, G. E., Chen, E., Sze, J., Marin, T., Arevalo, J. M. G., Doll, R.... Cole, S. W. (2008). A Functional Genomic Fingerprint of Chronic Stress in Humans: Blunted Glucocorticoid and Increased NF-кB Signaling. Biological Psychiatry, 64(4), 266272.

Ministry of Family, Labour and Social Policy of Poland. (2016).

Retrieved from www.mpips.gov.pl/aktualnosciwszystkie/art,5539,8468,wczesniej-na emerytureodpazdziernika-2017.html

Ministry of Labour and Social Affairs of Slovakia. (2014). The

National Program for Active Ageing for the Years 2014-2020 in Slovakia. Retrieved from

www.employment.gov.sk/files/ministerstvo/konzultacneorgany/rada-vlady srludske-prava-narodnostne-mensiny-rodovurovnost/narodny-program aktivnehostarnutia-roky-20142020.pdf

Ministry of Labour and Social Affairs of the Czech Republic. (2014). National Action Plan for Positive Ageing for the Period 2013- 
2017. Retrieved from

www.mpsv.cz/files/clanky/21727/NAP_EN_web.pdf

Moraal, D., \& Schönfeld, G. (2006). Main Features of Age-oriented

Policies in Austria, Belgium, Denmark, Germany and the

Netherlands. Retrieved from

www.bibb.de/dokumente/pdf/BIBB-synthesisreport-final.pdf

North, M. S., \& Fiske, S. T. (2012). An Inconvenienced Youth?:

Ageism and its Potential Intergenerational Roots. Psychological Bulletin, 138(5), 982-997.

OECD. (2014). Elderly Population (indicator). Paris. Retrieved from http://dx.doi.org/10.1787/8d805ea1-en

OECD. (2015). Ageing and Employment Policies: Poland 2015. Paris. Retrieved from http://dx.doi.org/10.1787/9789264227279en

OECD. (2016). OECD Employment Outlook 2016. Retrieved from www.oecdilibrary.org/employment/oecd-employmentoutlook_19991266

Radovic-Markovic, M. (2013). An Aging Workforce: Employment Opportunities and Obstacles. Cadmus, 1(6), 142.

Saunders, G. H., \& Echt, K. V. (2007). An Overview of Dual Sensory Impairment in Older Adults: Perspectives for Rehabilitation. Trends in Amplification, 11(4), 243-258.

Silverstein, M. (2008). Meeting the Challenges of an Aging Workforce. American Journal of Industrial Medicine, 51(4), 269-280.

Šoltés, M., \& Modráková, E. (2012). Analysis of Pension System Development in Slovak Republic. Psychological Bulletin, 3, $1238-1242$.

Szukalski, P. (2014). Zagrożenia dla aktywności osób starszych na rynku pracy w Polsce [Threats to active ageing in the labor market in Poland]. Retrieved from

http://dspace.uni.lodz.pl:8080/xmlui/bitstream/handle/11089/498

4/1.\%20Szukalski.pdf?quenc $=1$

United Nations, Department of Economic and Social Affairs

Population Division. (2015). World Population Ageing 2015.

Retrieved from

www.un.org/en/development/desa/population/publications/pdf/a geing/WPA2015port.pdf 
World Health Organization (WHO). (2010). Definition of an Older or Elderly Person. Retrieved from www.who.int/healthinfo/survey/ageingdefnolder/en/index.html

Zweifel, P., Felder, S., \& Meiers, M. (1999). Ageing of Population and Health Care Expenditure: A Red Herring? Health Economics, 8(6), 485-496. 

Suggested Citation: Felska, A. (2017). Folk High School as an Educational Alternative for Older Adults. In Ł. Tomczyk \& A. Klimczuk (Eds.), Selected Contemporary Challenges of Ageing Policy (89-102). Kraków: Uniwersytet Pedagogiczny w Krakowie. Doi: 10.24917/9788380840911.5

\title{
ANGELIKA FELSKA ${ }^{1}$ \\ Folk High School as an Educational Alternative for Older Adults
}

\begin{abstract}
There is just one challenge for a twenty-first century person, and it is an omnipresent change. In order to exist successfully and effectively in such a reality, one should constantly develop and take part in an educational process (formal and informal). A huge number of places directing their educational offer to seniors and use this alternative education, which is, on the other hand, often thought to be directed to children. In the author's opinion, a form of alternative education for adults and seniors is a folk high school in its contemporary version. That thesis is being discussed in this chapter.
\end{abstract}

Key words: Alternative Education, Folk High Schools, Lifelong Learning

\section{Introduction}

As the population of senior citizens has been growing in Poland (as well as in all of Europe) for at least a decade, as observed, and the average life expectancy lengthens, andragogists continually ask themselves about changes which take part in the educational area of senior citizens.

\footnotetext{
${ }^{1}$ Angelika Felska, Faculty of Humanities, University of Szczecin, Poland, angelika.iwaszkiewicz@wp.pl.
} 
The postmodern world somehow makes every man and woman, at every age, take up the initiative in the field of education, so senior citizens are no exception here. Talking about education nowadays one does not only bear in mind acquiring new knowledge or skills, but also expanding expertise mastered before, teaching inwardness, creative thinking and forming communication competence. Augustyniak writes that "today adults learn different things using other forms and methods of work" (Augustyniak, 2010, p. 155).

So, it is possible to assume that searching for alternative forms of education in order to make an offer for the discussed age group attractive ones and fulfilling their needs and expectations is the main aim of the present and future education of senior citizens.

Therefore, the aim of this chapter is a presentation of the contemporary folk high school as one of the educational alternatives for senior citizens. The Kashubian Folk University and its project entitled: "Wandering Folk University for Senior Citizens" is an example of the folk high school that runs its educational business for this exceptional age group.

\section{A Senior Citizen, Who Exactly?}

In everyday speech, a notion "senior citizen" is interchangeably used with terms such as an elderly person, grey beard, retiree, pensioner, or an old citizen. However, it is necessary to be aware of the fact that the term should not be used interchangeably, although it lacks explicit definition, as it is used to describe one of the stages of human life which are adulthood/ senility.

In andragogical and gerontological literature it is possible to find at least a few classifications of a mature person's stages of life. According to the World Health Organization (WHO) we can talk about young old (aged 60-75), middle old (aged 75-90) and very old (90 and older). Dubos (2007), on the other hand, divides adulthood into its preadulthood (18 -25 year of life), early adulthood (25-40), middle adulthood (40-60 or 65 year of life), late adulthood (60 or $65-80$ years of life) and senile adulthood (over 80 years of age). It is also worth underlining that the time of senility, as a stage of life, is nowadays 30-40 years and researchers pointed out the need of dividing this stage into two or three phases 
(the third or fourth age or young, middle, or late senility) (Bugajska, 2015).

Due to a lack of unambiguous definition of a term "senior" in modern andragogical and gerontological literature, in this chapter the above word will be used concerning people over 60 years old.

It is worth mentioning that scholars describe senility in its numerous aspects. Therefore, we talk about calendar, mental, social, biological, economical, or legal age. Such broad range of the issue causes a lot of terminological and methodological problems.

\section{Alternative Education}

According to a "Contemporary Polish Language Dictionary" edited by Dunaj, the word "alternative" means "possibility or necessity of choice between two preclusive things or courses of action" (Dunaj, 1996, p. 12). However, when I used the word alternative in the title of this chapter I was not driven by the lexical meaning of the word, but I was rather referring it to a paradigm of an alternative school (Kupisiewicz, 2010).

My understanding of the alternative definition, in reference to education, is similar to the one by Konarzewski, who wrote that "alternative in this nonstandard meaning is the same as distinct from dominant forms. In the broad understanding of education, which includes both forms of practice and forms of thoughts, which justify the practice, alternative education would include all kinds of educational action and thinking, which consciously differ from practice and theories dominant in the given time and period. Assuming that dominant forms represent the standard of the majority of the society, alternative education can be called education of the minority" (Konarzewski, 1995, p. 31). Then, folk high schools are, with no doubt, institutions of a minority nature, because they have never existed in mass numbers on the Polish territory. There have never been very many folk high schools, and the number of graduates has rather shown that some kind of elite attends there and the institutions are not places of common education. 
So, what is the presented school or alternative education? In "Pedagogical Encyclopedia" edited by Pomykało one can read that "a constructive feature of this school, alternative towards the one called conventional or traditional, is its openness towards the surrounding things, the creative and enlightened, which makes students act unassisted, pushes them to unprompted cognitive activity, which shapes and develops their interests, fulfills their multifarious intellectual and emotional needs, teaches them selfstudy, stimulates group work, so summing up-it favors multilateral development of children, youth, and adults" (Kupisiewicz, 1996, p. 784). It is another premise which determines folk high schools, according to the author of this chapter, as forms of alternative education. The fact that folk high schools have always aimed at both: intellectual and emotional development of the student having an effect on him or her with "real words," working in groups and living in dormitories, proves that. A significant pressure has also been put on self-studying and self-development during long courses. However, learning through practical action has favored multifarious and multifaceted development. So, referring Kupisiewicz's words to education at folk high schools, it is possible to judge that it is the alternative education indeed.

Ten years later Kupisiewicz extends the above definition a bit and adds, that alternative schools are "educational establishments, where all—or only some - components of planned and systematic training are executed differently than in schools working according to typical assumptions of a traditional school. That is why the alternative idea of schools can be complete or partial" (Kupisiewicz, 2006, p. 85).

In a lexicon of Polish Scientific Publishers (PWN) "Pedagogy" edited by Milerski and Śliwerski, on the other hand, we encounter the expression of alternative bringing up, which is to be understood as "a kind of bringing up referring to different premises, rules, forms or contents from customary education or institutionally popularized in a given country or approved; a concept of alternative upbringing is not aggressive, so into educational alternatives one can include pedagogical innovations, authorial projects in upbringing and educational areas as well as 
strands which are absent or rarely encountered in existing educational practice" (Milerski, Śliwerski, 2000, p. 13).

It is possible to notice that defining education, upbringing or alternative school has been described in literature both, in a broad way (Milerski, Śliwerski) and a narrow one (Kupisiewicz). However, it is not so crucial "what" we exactly define the terms described, but the fact that "extraordinary power of educational alternatives is their endlessness, infinity and permanence. There is not one alternative education against one conventional, traditional education. There will always be appearing educators or group initiatives, which will be aiming at asking for a different solution, other contents, forms or methods of introducing and conducting them in upbringing and educational practice" (Śliwerski, 2008, p. 9 ). The example is folk high schools, which have always been in opposition to traditional education because of their forms and methods of work. Moreover, the fact that "Schools for Life" have managed to survive for decades proves their uniqueness and social demand for both: such institutions and alternative education.

\section{Seniors' Education}

A term education comes from Latin educate that meant to bring up and educate. So, education is "a generality of intergeneration influences serving forming entirety of man vital abilities (physical, cognitive, aesthetic, moral and religious ones), turning a man into a mature human being who consciously fulfills his aims, settled in the culture and capable of constructive criticism of contemplative positivity" (Milerski, Śliwerski, 2000, p. 58).

Due to the paradigm of whole life education spreading around, the need for older adults' education development has been noticed. Just as Halicki states, seniors' education should be understood in a broad spectrum; it ought to be learning any forms of knowledge, abilities, and basics, which may help to improve the quality of older adults' lives (Halicki, 2000).

More and more numerous andragogical research projects (Czerniawska, Halicki, Fabiś, Dubas) prove, that the process of seniors' education can be considered in various areas: aims of education, needs of people who study, their motivation, possibilities of learning (biological, mental and social), forms, 
methods, contents and measures, as well as sociocultural or civilizational conditioning (Dubas, 2007). As the topic of this chapter only relates to educational institutions for older adults, I will stick to this idea further on.

Nowadays, it is possible to name up to a dozen or so forms of older adults' education in Poland, and the number is still growing. The most common institution among this age group is unquestionably the University of the Third Age. In Poland, the first one was set up in 1975 (Warsaw) and now there are 575 such institutions in the whole country, with 96370 seniors studying there (data from the academic year 2014 and 2015) (CSO Central Statistical Office, 2016). It is possible to differentiate three "types" of the Universities of the Third Age in Poland: (1) educational establishments at universities; (2) establishments set up by associations, which perform popular science activity; (3) institutions at community centers, libraries or daily house of social support.

Another, important forms of seniors' education are organizations which operate within universities structures, and that means that senior citizens are a part of the academic life of the high school. They take part in the lectures as "auditors," special lectures, seminars and conferences are organized especially for them. A good example of such a form of education may be the Szczecin Humane University of Senior (SHUS) operating within a Department of Szczecin Humane University, initiated by Bugajska (http://shus.whus.pl/o-nas/).

One is not to forget that institutions and organizations such as seniors' clubs, seniors' academies, associations, funds, libraries, rural host circles or local councils also run educational activities aimed at older adults. As I have already pointed out in this part of the chapter, the number of educational forms for older adults has been growing but it is not a reason to lapse into extreme enthusiasm, because as Trafiałek writes "demographic, old age rises much quicker than the development of educational activation institutions for seniors" (Trafiałek, 2005, p. 77). Therefore, it is necessary to remember that popularization of different forms of seniors' education is becoming a peculiar challenge for present educational politicians. 


\section{Folk High School}

Nikolaj Frederik Severin Grundtvig, a Danish philosopher, a reverend, writer, and pedagogist, is thought to be a father of the folk high schools' idea. He was the first one to present his idea of academic folk institution worldwide in an essay entitled "School for Life and Soer Academy" (Skolen for Livet og Academieti Soer) (Dam, Gaertner, 2008). That was in 1838, and seven years later in 1845 Christian VIII (Danish lord) passed a decree about setting up a Real High School in Soer, which was to realize Grundtvig's ideas. However, the project resulted in failure. There were a few reasons for the failure, but the most important ones were: questioning both forms and methods preached by Grundtvig in those times; in fact, the Academy in Soer was aiming at young people, not adults; the "political" disapproval of M.F.S. Grundtvig; and the idiosyncrasy of "clergy" for the father of folk high school idea (Maliszewski, Pierścieniak, 2016).

As Świeżyński wrote in a quarterly "Promień" ("Ray") in 1924 "the first folk university was set up in Roedding, Denmark in 1844 in the south of Jutland. Ludvig Schroder, Ernst Trier, Jens Nórregaard and had remarkable achievements in spreading the idea and setting up folk high schools. A teacher Christian Kold was also totally devoted to the idea" (Świeżyński, 1929, p. 100). The latter one extended Grundtvig's concept adding obligatory, communal living in a dormitory, sovereignty of students and introduced a higher number of practical actions to educational schedules of "School of Life" to it (Wolert, 1939; Maliszewski 2016).

As it comes out of literature of education history, folk high schools became of great interest not only in the idea homeland but also in the majority of European countries and even on the North American continent.

For the first time, the idea of folk high schools came to Poland thanks to a priest Antoni Ludwiczak who entered the office in Dalki in 1921, and later in 1923 thanks to Ignacy Solarz who was in charge of the institution in Szyce and next in Gacia near Przeworsk (Maliszewski, 2003). The high schools above mentioned based their actions on the idea of Grundtvig pedagogy. However, the school directed by the priest Antoni Ludwiczak was 
promoting patriotic upbringing based on Polish nation's deep Catholic faith. He was convinced that "the main thought that led initiators of folk high school was the love of the homeland and the need to create patriotic citizens for the country. The same thought motivated us when we started the action of setting up Folk High Schools, and we even dare to say, that the development of these schools depends on these principles: religious and national ones" (Ludwiczak, 1929, p. 97). Thanks to such management philosophy of folk high schools, the priest Antoni Ludwiczak gave a peculiar character to institutions under the patronage of People's Libraries Society.

The second of the fathers of folk high schools (the first one according to educational historians) - Ignacy Solorz, also based his educational activity on M.F.S. Grundtvig assumptions, but he sorts of adjusting them to Polish needs and realities. A detailed educational plan and authorial pedagogic conception (often called "coiling") let the institutions in his charge become phenomenal. Thanks to those features and features of his character-truly pedagogical one-Ignacy Solorz was able to influence people in rural areas strongly, and his deep faith in their intellectual potential enabled him to achieve remarkable pedagogic success. Moreover, it led him to become a known personality in Polish education history.

Since setting up the first folk high school in Poland, those institutions have been more or less popular, and their history has been chequered. There was a time when there were only a few such institutions in the whole country, but there was also time, the interwar period when there were up to 80 schools (Pilch, 2007). Despite that, folk high schools have never been as popular as they are in Denmark, Sweden, or Germany.

So, what is a folk high school nowadays? Years ago, Ryszard Wroczyński defined those institutions as "high schools for folks, which gave rural youth a chance to learn the basics of folk and national culture. Through a peculiar pedagogic atmosphere-which included: living in a dormitory, alumnus social activity, artistic forms development: musical, vocal and theatrical—rural activists staff was trained and they were returning 
to villages where they became the initiators of social and cultural movement of the community" (Wroczyński, 1987, p. 165).

Nowadays it is difficult to get a clear-cut definition of folk high schools. We may presume that authors avoid giving a specific definition, and there are also voices that there is a need of redefining folk universities. So, let me present an extract from "A Declaration of Folk University in Denmark," where it is stated that "when educating, folk high schools should enable to connect fundamental human approach with practically useful knowledge and engaging in cultural and social issues" (Aegidius, 2016, p. 17). A Polish point of view should be added to this chapter, the one presented by Maliszewski and Rosalska in one of their papers where they write that "folk high school is a community of learners mounted democratically, which gives the opportunities for development - both in personal and social area, it allows to use time wisely and flexibly choose forms of reaching various targets, and encourages community to contribute to the program" (Maliszewski, Rosalska, 2016, p. 11).

The modern view of the folk high schools in Poland shows a huge potential of these educational institutions for adults. Moreover, although now, there are only six folk high schools in Poland (based on my research), one can hope that the year 2016 could be beginning to a peculiar renascence of those exceptional educational institutions. Hopes arose when Polish folk high school community (Folk High School National Network) and the Ministry of Culture and National Heritage took up an initiative of framing a National Program of Development Support of Folk High Schools (NPWRUL), which will be introduced in 2017 as a pilot program (Felska, 2016). The team working on this document has to create legislative regulations, which will aim to (similarly to Denmark, Sweden, or Germany) regulate the functioning of "Schools for Life" in Poland, and to create general rules of their existence and operation.

Folk High School As an Educational Alternative for Seniors on the Example of the Kashubian Folk University

Grundtvig created the idea of a folk high school in order to oppose Latin system of higher education. In that way "Schools for Life" 
became the educational alternative for adults. As we can read in Pedagogic Encyclopedia "Danish variation of alternative school derives from school traditions endorsed by Grundtvigdormitories and folk high schools, which were of crucial importance in the development of adult education in Scandinavia" (Pomykało, 1996, p. 786). Gołębiewski thought alike, years ago, he wrote that "folk high schools were set up as alternative institutions for schools and they protect their non-school profile until now" (Gołębiewski, 1999, p. 179).

As the analysis of literature in the field of education history shows, folk high schools had a crucial role of educational institutions for seniors already in the 1970s. Maliszewski even writes that "throughout the whole twentieth century different nations successfully experimented with opening their own folk high schools to more and more students" (Maliszewski, 2010, p. 57).

Records in the literature and initiatives undertaken in that area in Poland prove the real openness of folk universities communities to educate the eldest group of the society. A quote from Halicki from 2000 proves the former: "folk high schools have been educating seniors since the 1970s. The first folk high schools for seniors have also been created as the departments of folk high schools" (Halicki, 2000, p. 55). Moreover, the latter one is proved by specific activities, such as initiative called "Wandering Folk High School for Seniors" organized by Kashubian Folk University in Wieżyca. The first edition of this project took place in 2013, and the second one in 2016. The idea of "Wandering Folk High School for Seniors" is aimed at people over 60, living in Kartuski and Lęborski county (Borowska, 2016). Activists from Kashubian Folk High School phrased their offer in a way it would enable them to attract seniors who did not have an opportunity to enjoy educational offer in their local communities. As the originators, they underline that "Wandering Folk High School for Seniors" project: "was to become an attempt to answer seniors' needs. As the main aim, we have pointed out the activity enhancement in the social life of older people living in the Kashubian villages - in particular motivating them to active 
participation in various forms of educational, cultural and social activity" (Maliszewski, 2016, p. 73).

\section{Conclusion}

From the perspective of the multiannual tradition of folk high schools operating for the benefit of the oldest age group, such as seniors, and from the analysis of the contemporary conducted initiatives, it is possible to say that "Schools for Life" are an educational alternative for seniors now as well as in the future. As Maliszewski states "when looking for current and future optimal educational solutions it is important not to forget numerous values, concepts well known from the history of education and pedagogy, the ones which served generations for consecutive decades of the twentieth century (and some of them even earlier) with really positive effect, because creative modification of tested educational patterns from the past, in order to prepare them to fulfill modern (and future) educational tasks may bring significant social effects" (Maliszewski, 2010, p. 52). Such a role the author of the chapter looks for in folk high schools, which, according to him, are a form of alternative education, also for senior citizens. Meeting social expectations, and also social needs folk high schools are somehow obliged to prepare their educational offer bearing in mind the seniors. A demographic forecast has been unambiguous for years and it shows that Polish society is getting older and older, and a lifespan in good health and intellectual condition lengthens, which means that educational institutions should prepare themselves to employ qualified andragogists and to adjust syllabuses to seniors. As the work on the National Development Support Program of Folk High Schools in Ministry of Culture and National Heritage (Felska, 2016) states, that the whole community of National Network of Folk High Schools notices that the group that is truly interested in the offer of the existing folk high schools are senior citizens.

\section{References}

Aegidius, K. K. (2016). Szkic o Grundtvigiańskich ideach szkoły dla życia we współczesnych czasach [Sketch of Grundtvigs ideas of the school for living in modern times]. In T. Maliszewski (Ed.), 
Szkoła dla życia. Przewodnik po współczesnych uniwersytetach ludowych [School for life: A guide to modern folk high schools] (pp. 19-24). Wieżyca-Grzybów: Kaszubski Uniwersytet Ludowy.

Augustyniak, E. (2010). Edukacja dorosłych - potrzeba czy konieczność? [Adult education - the need or necessity?]. In T. Aleksander (Ed.), Edukacja dorostych jako czynnik rozwoju społecznego [Adult education as a factor of social development] (pp. 152-157). Radom: Wydawnictwo Naukowe Instytutu Technologii Eksploatacji.

Borowska, S. (2016). Wędrowny Uniwersytet Ludowy dla Seniorów jako przykład działalności Kaszubskiego Uniwersytetu Ludowego [Traveling People's University for Seniors as an example of Kashubian People's University]. In T. Maliszewski (Ed.), Szkoła dla życia. Przewodnik po współczesnych uniwersytetach ludowych [School for life: A guide to modern folk high schools] (pp. 71-76). Wieżyca-Grzybów: Kaszubski Uniwersytet Ludowy.

Bugajska, B. (2015). Tożsamość człowieka w starości. Studium socjopedagogiczne [Identity of man in old age: Sociopedagogical study]. Szczecin: Wydawnictwo Naukowe Uniwersytetu Szczecińskiego.

Byczkowski, M., Maliszewski, T., \& Przybylska, E. (2003). Uniwersytet ludowy - Szkoła dla życia [Folk high schoolschool for life]. Wieżyca: Kaszubski Uniwersytet Ludowy.

Dam, P., \& Gaertner, H. (2008). Mikotaj Fryderyk Seweryn Grundtvig 1783-1872 [Nikolaj Frederik Severin Grundvig 17831872]. Kraków: Wydawnictwo WAM.

Dubas, E. (2007). Paradygmat uniwersalności w edukacji dorosłych [The paradigm of universality in adult education]. In E. Dubas (Ed.), Uniwersalne problemy andragogiki i gerontologii [Universal problems of gerontology andragogy] (pp. 41-66). Łódź: Wydawnictwo Uniwersytetu Łódzkiego.

Dubas, E. (2009). Etapy dorosłości i procesu kształcenia [The stages of adulthood and the process of education]. In B. Cyboran \& A. Fabiś (Eds.), Dorosty w procesie kształcenia [An adult in the process of education] (pp. 115-132). Bielsko-Biała, Zakopane: Wyższa Szkoła Administracji. 
Dunaj, B. (1996). Słownik współczesnego języka polskiego [Dictionary of contemporary Polish language]. Warszawa: Wilga.

Felska, A. (2016). Spotkanie Ogólnopolskiej Sieci Uniwersytetów Ludowych w Radawnicy [Meeting of the National Network of Popular Universities in Radawnica]. Polski Uniwersytet Ludowy. (1-2), 118-120.

Gołębiowski, B. (1999). Megatrend XXI wieku. Uniwersytety ludowe [Megatrend the twenty-first century: Folk universities]. Rocznik Andragogiczny, 174-181.

GUS. (2016). Uniwersytety Trzeciego Wieku w roku akademickim 2014/2015 [Third Age Universities in academic year 20142015]. Warszawa.

Halicki, J. (2000). Edukacja seniorów w aspekcie teorii kompetencyjnej. Studium historyczno-porównawcze [Seniors education in the aspect of competence theory: A historicalcomparative study]. Białystok: Wydawnictwo Uniwersytetu w Białymstoku.

Konarzewski, K. (1995). Edukacja alternatywna a zmiana oświatowa [Alternative education versus educational change]. Spoleczeństwo Otwarte. (11), 31-34.

Kupisiewicz, C. (1996). Szkoła alternatywna - założenia egzemplifikacje [Alternative school-assumptions exemplifications]. In W. Pomykało (Ed.), Encyklopedia Pedagogiczna [Pedagogical encyclopaedia] (pp. 784-790). Warszawa: Fundacja Innowacja.

Kupisiewicz, C. (2006). Szkoła $w$ XX wieku [School in the twenty-first century]. Warszawa.

Ludwiczak, A. (1929). Ideologia narodowa w Uniwersytetach Ludowych [National ideology in people's universities]. Promień. (Październik-Grudzień, R5/4), 97-99.

Maliszewski, T. (2010). Z ludźmi - ku ludziom. Tradycje XX wieku versus przyszłość edukacji dorosłych [With people — towards people: the traditions of the twentieth century versus the future of adult education]. In M. Brodnicki, E. Gorloff, \& A. Kołakowski (Eds.), Wychowanie - opieka - ksztatcenie. Z badań nad wybranymi problemami edukacji w XX $i$ XXI wieku [Education-care-education: From research on selected issues 
of education in the twentieth and twenty-first centuries] (pp. 4561). Toruń: Wydawnictwo Akapit.

Maliszewski, T., \& Rosalska, M. (2016). Uniwersytety ludowe pomiędzy starymi a nowymi wyzwaniami [Folk universities: between old and new challenges]. Toruń: Wydawnictwo Adam Marszałek.

Milerski, B., \& Śliwerski, B. (2000). Leksykon PWN. Pedagogika [PWN lexicon education]. Warszawa: Wydawnictwo Naukowe PWN.

Pilch, T. (2007). Uniwersytet ludowy [Folk high school]. In T. Pilch (Ed.), Encyklopedia Pedagogiczna XXI wieku. Tom 6. [The twenty-first century teaching pedagogical encyclopaedia. Volume 6] (pp. 1019-1034). Warszawa: Wydawnictwo Akademickie Żak.

Śliwerski, B. (2008). O nowym modelu szkoły alternatywnej [About the new alternative school model]. Kwartalnik moj@klanza.org.pl. (3),6-10.

Świeżyński, R. (1929). Uniwersytety ludowe w Danii i ich znaczenie dla Polski [Danish folk universities and their significance for Poland]. Promień. (Październik-Grudzień), 99-107.

Trafiałek, E. (2005). Edukacja, integracja i aktywizacja ludzi w starszym wieku. Polska a Europa [Education, integration and activation of older people Poland and Europe]. In A. Fabiś (Ed.), Seniorzy w rodzinie, instytucji i spoleczeństwie. Wybrane zagadnienia wspótczesnej gerontologii [Seniors in the family, institution and society: Selected issues of contemporary gerontology] (pp. 77-88). Sosnowiec: WSZiM.

Urbańczyk, F. (1973). Problemy oświaty dorostych [Problems of adult education]. Warszawa: Państwowe Zakłady Wydawnictw Szkolnych.

Wolert, W. (1939). Demokracja i kultura. Praca oświatowa za granica. Kierunki, organizacje, typy, działalność metody [Democracy and culture: Educational work abroad: directions, organizations, types, activity methods]. Warszawa: Społecznowychowawczy Związek Spółdzielni Spożywców Rzeczypospolitej Polskiej.

Wroczyński, R. (1987). Dzieje oświaty polskiej 1795-1945 [The history of Polish education 1795-1945]. Warszawa: Wydawnictwo Naukowe PWN. 
Suggested Citation: Selecký, E. (2017). Organization of International Educational Activities at the Universities of the Third Age. In Ł. Tomczyk \& A. Klimczuk (Eds.), Selected Contemporary Challenges of Ageing Policy (103-120). Kraków: Uniwersytet Pedagogiczny w Krakowie. Doi: 10.24917/9788380840911.6

\title{
ERIK SELECKÝ'
}

\section{Organization of International Educational Activities at the Universities of the Third Age}

\begin{abstract}
The organization of an international education activity has its specifics compared to a national one. It is very important to know the differences in the very organization as well as the opinions of the individual participants. We can find differences not only in the management of education but also in the leisure activities, the nourishment, and the accommodation. Based on experiences with the organization of international events and taking part in international projects in the field of educating older adults, we put together a questionnaire to investigate some important questions related to the organization of an international event. We distributed this questionnaire at two international educational activities. We compiled the questions and answer clearly, which is going to be an asset particularly for the professional community.
\end{abstract}

Key words: International Cooperation, Lifelong Learning, University of the Third Age

\section{Introduction}

The Universities of the Third Age (UTA) in Slovakia actively cooperate with the international association of the Universities of

\footnotetext{
${ }^{1}$ Erik Selecký, Technical University in Zvolen, Centre for Further Education, Slovakia, erik.selecky@tuzvo.sk.
} 
the Third Age (AIUTA; French: Association internationale des Universités du troisième âge). There are more than 23 member countries, however, according to R.F. Swindell (2012), UTA exist in more than 60 countries around the world. AIUTA organizes an international congress once every two years and supports projects of development and cooperation of education in the third age. Another very significant organization which deals with educating the seniors is WorldU3A, established in the year 1997, which predominantly focuses on the support of e-education (Swindell, 2012). In Europe, we can talk about two basic models of educating seniors: the French and the English. The French model focuses on educating older adults at universities, and the English model focuses on making use of the public and the private spaces (Selecký, 2014). According to J. Yenerall (2003), Finish UTA students attend lectures at universities in combination with local educational groups by means of the open-door policy. For further comparison, we can characterize education in Malta, where there is a combination of university education supplemented by group session (Formosa, 2012). Additional examples in the world tell us about the typical French model which is implemented in Canada (Lemieux, 1995), and for example in Taiwan, where educating the seniors is not connected to universities but is managed and financed by the local authorities and the teaching is done by professional teachers (Huang, 2005). Based on these examples we can see several different approaches to educating the seniors.

The education at UTA cannot be defined as an education in senior age, but in consideration of the age structure and the possibility of acceptance in Slovakia, we have to talk about old adults and seniors. The managers of individual UTA have to communicate with the students whose age structure has a wide range from 45 years old to minimally 80 years of age or older.

A high added value for UTA students apart from the educational process, excursions, cultural and social, is the organization of international educational activities. We know that the highest interest is in the language and the computer education. Many of the students have families abroad and need to keep in touch with them, and in most cases, talk to the grandchildren. Another important factor is a high mobility which contributes to 
the more frequent use of the language competencies of the individual.

If we want to increase the motivation of UTA students for language education, we have to think about a way to implement it. Of course, UTA should not replace travel agencies, but they do have certain options to develop international cooperation through various project activities. UTA at the Technical University in Zvolen has a long tradition of more than 20 years. It belongs to the first UTA in Slovakia. We have more than 450 students in 18 academic fields. In 2011, we successfully managed to take part in an international project financed from the grant scheme Grundtvig Programme. Two years later, we were in another similar project, and nowadays we are in projects financed from the scheme Tempus and Erasmus Plus. We are going to introduce the basic differences between these programs briefly.

The Grundtvig Programme was a part of a European Lifelong Learning Programme (LLP 2007-2013). It focused on the European cooperation in the field of adult education. Center for Continuing Education (CCE) at the Technical University (TU) in Zvolen focused predominantly on the subprogram: "Learning partnerships," which supported projects of two-year cooperation in which educational institutions for adults from at least three countries took part. The emphasis was put particularly on an exchange of information and experiences and on an active project participation of adult learners in projects (Grundtvig, 2016).

The Tempus program is a part of an EU program which supports the modernization of the university education in the near surroundings of EU. It is focused on countries in Eastern Europe, Central Asia, Western Balkans, and the Mediterranean region. Especially consortia of institutions composed particularly of universities are being supported (Tempus, 2016).

The Erasmus Plus program provides grants for a wide spectrum of events and activities in the field of education, vocational training, youth, and sport. The program gives an opportunity to students, pupils of vocational training, pedagogical employees, youth workers and volunteers to spend time abroad and improves their knowledge, skills, and employability. The program supports organizations which can join the project 
cooperation and within the partnerships share innovations about education, vocational training, and youth (Erasmus Plus, 2016).

The main objective of the contribution is a familiarization with the results of the research which we carried out on 138 participants of international educational activities. The participants were managers, lecturers, and UTA students. We asked for their opinion: How to organize international educational activities? The secondary objective was an enrichment of theoretical knowledge and experience during the implementation of international educational activities for older adults and seniors.

\section{The Methodology of the Research}

The objective of the research is the investigation of the opinions of the participants of international educational activities who are commenting on the organization itself. Another objective of the research is the investigation of individual needs of an international educational event participant.

The main tool for finding the information was an anonymous questionnaire. The questionnaire was made especially for the purpose of improving the work organization-mainly of the international educational activities which are organized by CCE at TU in Zvolen. Since the employees of CCE attend multiple international events at home and abroad yearly, we felt a strong need to find out what the opinion of the participants is in the organization itself. In order for this questionnaire not to be generally thought of only for further education - it is closely linked mainly with the organization of international events in the environment of UTA. We put the questionnaire together in the year 2015, and it was distributed for the first time at the final meeting of the project named: "My passion, happiness - add to favorites" in June 2015 (Lubsko, Poland). At this meeting, there were around 100 participants from 6 countries of the European Union (Poland, Portugal, Turkey, Lithuania, Romania, and Slovakia). We arranged an individual distribution of the questionnaire, where we had more than $70 \%$ submission rate. This questionnaire was also translated, apart from the English language, to the Polish language because of a high number of resident seniors who did not speak the English language. We chose the 
following phase in the $4^{\text {th }}$ year of an international sports olimpic games for UTA students which took place in September 2015 in Zvolen. We distributed it to participants of olimpic games from these countries: Ukraine, Czech Republic, Poland, and Slovakia. The number of questionnaires which we received back was more than 60. It is very important to note that the target group was not chosen by chance, but they were participants of an international event, who took part in several activities, and the length of the very activity was in the interval of 4-5 days. By means of the questionnaire, we addressed three basic target groups: UTA managers (14), UTA lecturers (28), and UTA students (96). By estimation, we can split this group to $10 \%-20 \%-70 \%$.

Processing and evaluation of the questionnaires-we evaluated each question individually in the Excel software. We used charts and graphs for the evaluation.

During processing the results and the discussion, we used the method of comparison and abstraction.

\section{Results and Discussion}

We divided the questionnaire structure into two parts. The first part deals with questions which relate to practical experiences with the organization of international activities and the second part investigates basic identification data about the participant.

We are going to present all questions asked to the respondents together with possible answers, and we are also going to clarify the objective of the author as to why he chose this question. In the following part, we are going to graphically represent some of the answers which were a result of the research, and we are going to enrich them with an own commentary.

1. question: What kind of transportation do you prefer? (Car, Bus, Train, or Plane)

From an economic standpoint, we mainly prefer an automobile transportation during the mobility of the participants at a shorter distance. Apart from the management, our students also participate in driving the car. It is more economical when we do not have to order a bus, in which case not only the kilometers but also the bus waiting fee has to be paid for. If you travel for more days, the price for the bus waiting fee reaches high amounts. The 
train is considered to be the most comfortable way of traveling within Europe. However, the main disadvantages are a high price as well as a problematic connection to smaller places. Colleagues from Portugal and Turkey generally marked the plane, which is self-evident because their distance is incomparably larger than distances in Central Europe. more)

2. question: How many days do you prefer? $(1,2,3,4,5$, or

It is a significant indicator of the management of an international event. It is necessary to realize, that a sensitive approach to the organization is inevitable, mainly due to distinct nationalities, customs, cultures, and religions. It is also necessary to divide the activity into educational, cultural, social. If I do an international education training, I have to supplement it with a suitable social side. It is also necessary to remember that the participants like various cultural sights and want to find out as much as possible about the country.

3. question. What type of accommodation do you prefer? (Single-bed, Two-bed, Three-bed, Four-bed)

A very practical question. We are finding out ourselves that there are distinct approaches. If the management finances the activity, the participants are mostly likely to sleep alone, and when they have to finance it by themselves, it is not a problem to share a room with more people. The economy plays a significant role while occupying the rooms.

4. question: What time do you prefer for lunch? $(11-12,12-$ $13,13-14,14-15)$

5. question: What time do you prefer for dinner? $(17-18,18-$ 19, 19-20, 20-21)

From a multicultural and mainly a geographical viewpoint, the questions of planning lunches and dinners are very important. We know that countries in the south of Europe prefer later lunches and dinners. Sometimes us, Central Europeans, shake our heads at how it is possible to dine during later hours and then go to sleep. It is necessary to set the time distribution properly to avoid complaints from the side of the participants.

6. question: How many hours of free time a day do you prefer? $(0,0-1,1-2,2-3,3-4,4$-more $)$ 
We know from practice that a person needs time to oneself. The question is how much. Some participants are satisfied with a filled program from morning till evening; others need more unmanaged time. During planning, it is necessary to foresee a time reserve as well as the number of the participants. When we organize a "getting to know you" activity, the coefficient of the time reserve has to be higher.

7. question: What type of activity do you prefer at a meeting? (max. 3) (Sport, IT, Communication in English, Music, Dance, Drawing, Singing, Handiwork)

The choice of activities which we offered to the participants is based on years of observation of activities at international meetings. We found out that sport-dance-singing are the basic icebreaking tools among participants.

8. question: What type of sport do you prefer at a meeting (max. 3) (Football, Basketball, Volleyball, Pétanque, Bowling, Archery, Zumba, Table-tennis, Yoga, others...)

Sport and physical activities are a very important component of every multi-day event. As defined by the author M. Šrék (2009) "Even now, physical education and sport represent an important component of free-time education not only for adults but also for seniors." This is confirmed by another author focused on educating the seniors D. Gracová (2015) "Physical activities do not only prolong age but above all, add to the contentment, the self-sufficiency, the independence, develop the physical ability and have a great influence on the whole human body." By asking this question, we were searching for an answer to mainly discover what type of sports suits a particular age group.

9. question: What type of free-time activities do you prefer? (Shopping, Visit of a historical center-museums, castles, Sport, Nature)

Often we have come across participants preferring to go to the shop to buy something nice for their relatives, where they spent a lot more time than at the city tour itself. We are searching for an answer, whether the participants truly prefer shopping centers over interesting cultural, sport or nature activities.

10. question: What type of cuisine do you prefer? (Own national, international, or combination of both) 
At first glance, it is not an important question. However you would not believe, how much can an ignorance of this answer complicate and significantly disrupt the event organization. It is especially necessary to think about other cultures and take into account what specifics they have on their menu. It is ideal when lunches and dinners are buffet-style. However, this is not always feasible. Some nations prefer more vegetables; some do not eat beef, some prefer fish. Some are vegetarians, vegans. It is necessary to prepare properly for differences in nutrition and not forget to ask the participants whether they have any specific requests, rather than deal with meal replacement on the go, which does not always have to be a success.

11. question: What types of activities do you prefer for a better learning of the English language at a meeting? (Listening to a lecture, Communication in a pair, Communication in a small group, Communication in a large group)

Most older adults prefer communication in a foreign language in a large group. They do not like to draw attention to themselves; they rather want to "hide" behind someone else. It is an interesting finding mainly from a time standpoint-long-term research, how and if at all people change their opinion.

12. question: What type of educational tool do you use for learning the English language? (School, Computer, Movies, Books, Verbal communication, None, Other...)

Whether we like it or not, the English language is getting preferable as the world communication language. We know that some countries - mainly the Francophone ones, are advocates of protecting their mother language, and even though they can speak the English language, they do not want to communicate. We directed our question at the English language because we suppose that the English language is the number one at international meetings. It is necessary to confirm a well-known matter of fact "The more languages you know, the more you are human." This matter of fact is confirmed at our meetings, and sometimes the fundamentals of a language are enough to remove the basic communication barriers. 
13. question: What kind of communication do you prefer before and after a meeting (activity)? (Post, E-mail, Skype, Social networks-Facebook..., Other)

It is interesting to observe how fast the development of communication channels between organizations and people are moving forward. If we communicated via e-mail and the post several years ago, today it is moving to Skype, Facebook, and other social networks. This is connected to the question which should give an answer about the most effective communication tool for a particular age group. However, we have to emphasize that the limit of information and communications technology (ICT) knowledge is constantly shifting and the ICT knowledge and skills are constantly widening.

\section{Identification Data}

Nationality, Sex, Age, Economic position (Employed, Unemployed, Retiree), Level of education (Primary education, Secondary education, Higher education), Living with (number of residents)

\section{Answers to Identification Data Questions}

As we mentioned, the distribution of the questionnaire was carried out at an international educational activity in The Republic of Poland and in Slovakia. Due to this reason, there is a high portion of Slovak and Polish nationality. A great benefit is the representation of 8 nationalities. From a geographical viewpoint, it is mainly Central Europe. However, the representation of Turkish and Portuguese nationality has a significant influence.

The highest age representation is among respondents from 61-70 years. However, it is necessary to add that representation of the retiree age to the working one is $2: 1$ (i.e., $66 \%-33 \%$ ). Since the majority are UTA students, it is also confirmed by the sex statistics, that there are more than $70 \%$ women. The average in Slovakia is more than $80 \%$. This fact also confirms that more than two-thirds of UTA students are female. An interesting result is an answer to the level of education - up to $67 \%$ state to have a higher education. This data shows that the majority of respondents apart from UTA students have a university degree because they are 
managers and UTA collaborators and the majority of the student participants of international mobility has a higher education.

Figure 1 The Nationality of Respondents

The nationality of respondents

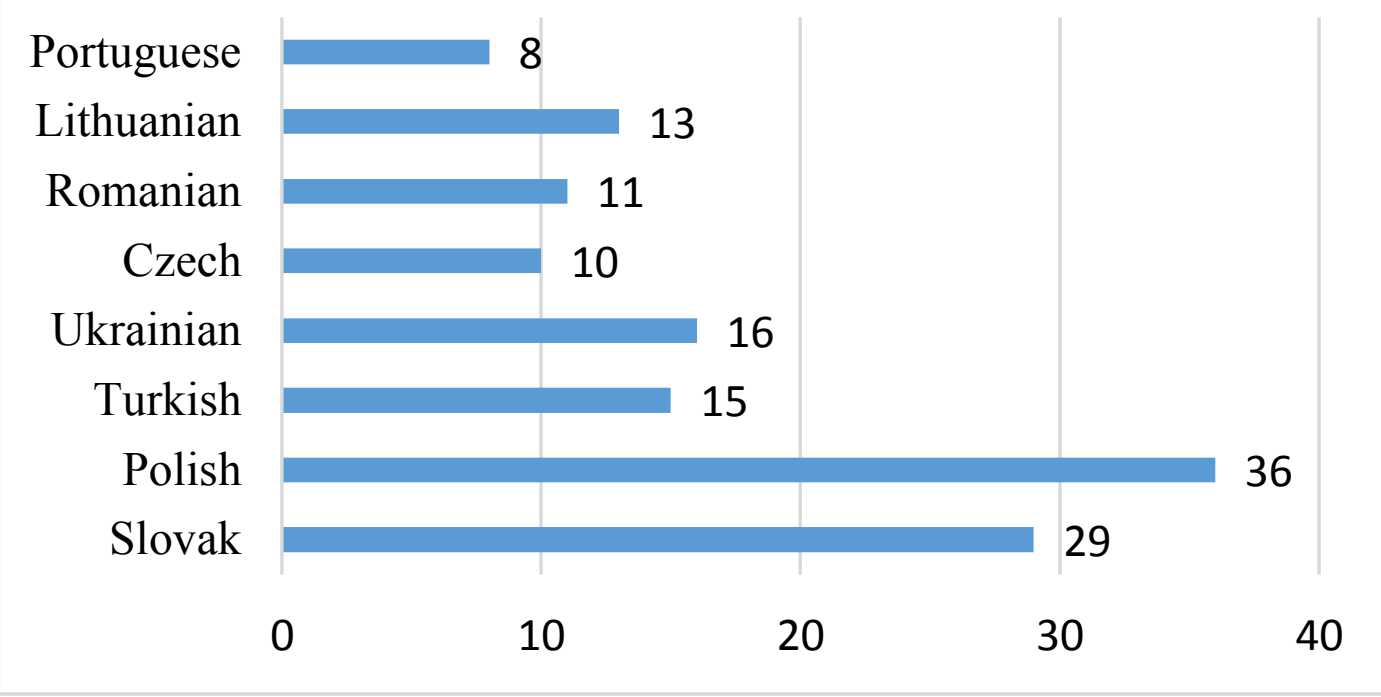

Source: Own elaboration.

Figure 2 The Age

The age

70 and more

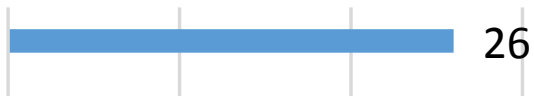

26

$61-70$

26

$51-60$

$41-50$

16

$31-40$

$18-30$

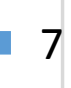

\section{7}

5

0

10

20

30

40

50

60

Source: Own elaboration. 


Table 1 Sex, Economic Position, and Level of Education
\begin{tabular}{|l|c|c|c|}
\hline Sex & Woman & \multicolumn{2}{|c|}{ Man } \\
& $92(71 \%)$ & \multicolumn{2}{|c|}{$38(29 \%)$} \\
\hline Economic & Employed & Unemployed & Retiree \\
position & $47(33 \%)$ & $1(1 \%)$ & $93(66 \%)$ \\
\hline Level of & Primary & Secondary & Higher \\
education & education & education & education \\
& $0(0 \%)$ & $45(33 \%)$ & $92(67 \%)$ \\
\hline
\end{tabular}

Source: Own elaboration.

Other Answers to Questions 1-13

The answer to question n.1: The preferred vehicle is the airplane, the bus, and the car $(30 \%)$. The train was placed on the fourth place with only $11 \%$. This confirms our assumption that despite the train popularity as a transportation, an important role is played by a combination of time and price.

The answer to question n.2: We can consider three days to be ideal, but the data about five days also stands out. These results can be influenced by a viewpoint factor. From the organizer's standpoint, the optimum of working days is 2-3, from the participant's standpoint, it is more than two days, mainly because when I travel I want to experience as much as I can and basically, it is not worth going anywhere for 2-3 days when I have to count in the journey there and back, which usually takes approximately 2 days.

The answer to question n.3: A very unexpected result in terms of percentages. Up to $82 \%$ of all respondents' state they would be willing to be accommodated in a two-bed room. We can assume two reasons for this. On the one hand, they are aware of the high costs of accommodation in a single-bed room, and on the other hand, we suppose the participants would rather stay in a pair than alone.

The answer to question n.4: A clear answer to the question asked is a lunch organization between 12 and 14 PM, in addition to that a half of all respondents leaning towards the 13-14 PM alternative. From an organizational standpoint, it is a very valuable information. It is not necessary to "push" the lunch to around 12 
PM, as we are used to in Central Europe, and so we do not have to be afraid to postpone it till $13 \mathrm{PM}$. If we reviewed the questionnaire answers in detail, the participants from Portugal and Turkey are in the majority leaning towards lunch organization in the 13-14 PM interval.

The answer to question n.5: By comparing all the options, it is clear that the best dinner organization is between 18-19 PM. If we had to "move" the dinner time, it should rather be later than earlier.

The answer to question n.6: A profoundly important question and appertaining answers. It follows from the questionnaire that respondents need 2 to 3 hours of time daily, which they want to use according to their taste. Whether for rest or other activities which they need to perform. We often meet with managers and UTA lecturers having to deal with work issues, and in the case of a "loaded" program, they have to find a space for it. If they do not find it during the day, they often struggle and are not focused on activities during the international event.

\section{Figure 3 Question n.8: What Type of Activity Do You Prefer at a Meeting (Max. 3)}

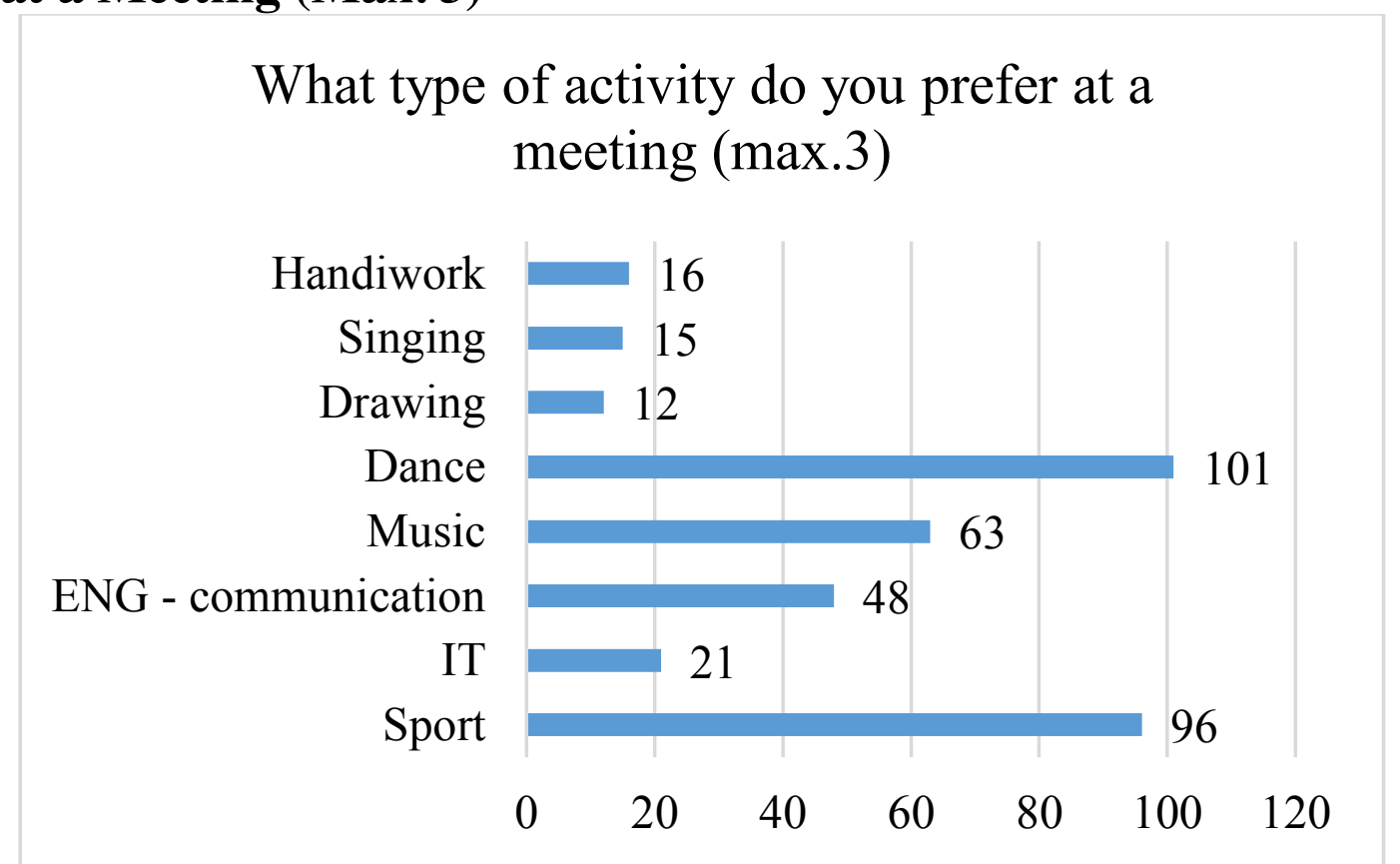

Source: Own elaboration. 
The answer to question n.9: Almost half of the respondents stated that they prefer sight-seeing during the free time. It is very gratifying that the smallest percentage out of all answers came to the international activity to shop. During the organization, the natural beauty of the particular region should not be forgotten because it feels good to take a walk-in nature after activities such as the educational ones.

Figure 4 Question n.9: What Type of Sport Do You Prefer at a Meeting (Max. 3)

What type of sport do you prefer at a meeting (max.3)

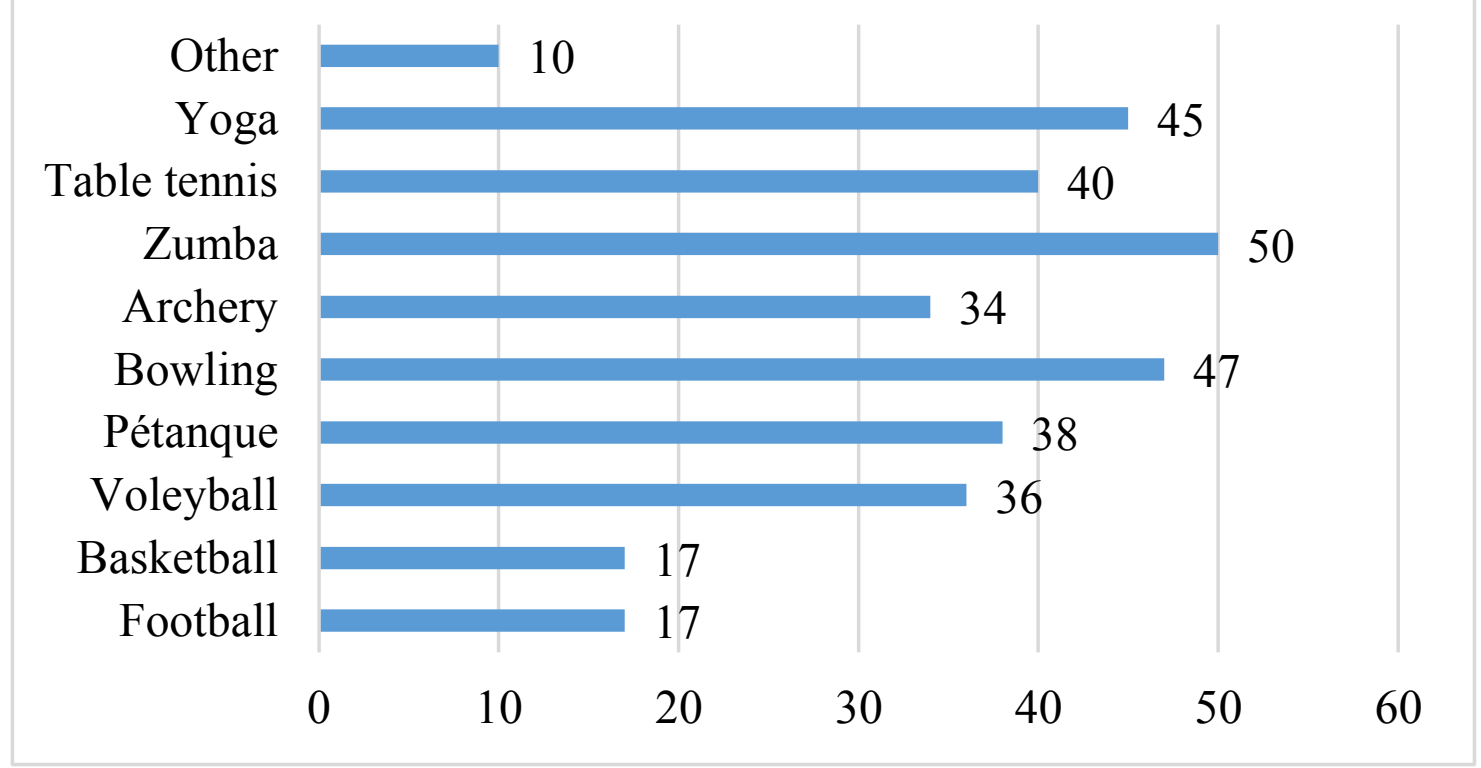

Source: Own elaboration.

The answer to question n.10: Not everybody enjoys national cuisines of particular states, and a large number of people do not want to try something new. Despite these assumptions, there is a very positive result of $85 \%$, in which the combination of food appears as the wisest solution. We recommend arranging national cuisine on some days and international-accepted by the general public, on others.

The answer to question n.11: Up to $54 \%$ of respondents stated that they prefer learning the English language by 
communication in a small group. It is gratifying that listening to lectures, communication in a pair and a large group placed evenly at the second place. It means that they are not interested in hiding in a large group, and communication in a small group is not a problem.

The answer to question n.12: The answer school and verbal communication ended up leading significantly. Since the respondents are mostly UTA students, it is also confirmed by this answer, that they are learning the English language at school and generally prefer verbal communication over the written one. The computer has quite a high percentage, and we assume its use to be a significant educational component.

The answer to question n.13: Almost $50 \%$ of the respondents stated that they prefer e-mail communication. The percentage of social networks is very interesting, and it ranges from $23 \%$. Due to an increasing use of social networks not only for communication purposes, we assume a constant development of this type of communication channel. It follows that it is important to pay increased attention to the creation and actualization of social networks for the organization of educational events.

\section{Table 2 Answers to Questions 1-6 and Questions 9-13}

\begin{tabular}{|l|c|c|c|c|c|c|}
\hline 1. & $\begin{array}{c}\text { Car } \\
42(27 \%)\end{array}$ & $\begin{array}{c}\text { Bus } \\
48(31 \%)\end{array}$ & $\begin{array}{c}\text { Train } \\
18(11 \%)\end{array}$ & $\begin{array}{c}\text { Airplane } \\
49 \\
(31 \%)\end{array}$ & & \\
\hline 2. & One & Two & Three & $\begin{array}{c}\text { Four } \\
27\end{array}$ & $\begin{array}{c}\text { Five } \\
34 \\
(20 \%)\end{array}$ & $\begin{array}{c}\text { And } \\
\text { more } \\
13\end{array}$ \\
& $2(1 \%)$ & $23(17 \%)$ & $38(28 \%)$ & $(9 \%)$ \\
\hline 3. & 1 -bed & 2 -bed & 3 -bed & $4-$ bed & & \\
& $18(13 \%)$ & $112(82 \%)$ & $7(5 \%)$ & $0(0 \%)$ & & \\
\hline 4. & $11-12$ & $12-13$ hours & $13-14$ hours & $14-15$ & & \\
& hours & $56(41 \%)$ & $65(49 \%)$ & hours & & \\
\hline 5. & $7(5 \%)$ & & & $7(5 \%)$ & & \\
& $17-18$ & $18-19$ hours & $19-20$ hours & $20-21$ & & \\
& hours & $70(52 \%)$ & $40(29 \%)$ & $\begin{array}{c}\text { hours } \\
11(8 \%)\end{array}$ & & \\
\hline
\end{tabular}




\begin{tabular}{|c|c|c|c|c|c|c|}
\hline 6. & $\begin{array}{l}0 \text { hours } \\
4(3 \%)\end{array}$ & $\begin{array}{c}0-1 \text { hours } \\
8(6 \%)\end{array}$ & $\begin{array}{l}1-2 \text { hours } \\
45(33 \%)\end{array}$ & $\begin{array}{c}2-3 \\
\text { hours } \\
63 \\
(46 \%)\end{array}$ & $\begin{array}{c}3-4 \\
\text { hours } \\
16 \\
(11 \%)\end{array}$ & $\begin{array}{c}4 \\
\text { hours } \\
\text { and } \\
\text { more } \\
1 \\
(1 \%)\end{array}$ \\
\hline 9. & $\begin{array}{l}\text { Shopping } \\
29(16 \%)\end{array}$ & $\begin{array}{c}\text { History } \\
84(48 \%)\end{array}$ & $\begin{array}{c}\text { Sport } \\
30(17 \%)\end{array}$ & $\begin{array}{c}\text { Nature } \\
34 \\
(19 \%)\end{array}$ & & \\
\hline 10. & $\begin{array}{l}\text { National } \\
12(8 \%)\end{array}$ & $\begin{array}{c}\text { International } \\
10(7 \%)\end{array}$ & $\begin{array}{c}\text { Combination } \\
115(85 \%)\end{array}$ & & & \\
\hline 11. & $\begin{array}{c}\text { Lecture } \\
21(14 \%)\end{array}$ & $\begin{array}{c}\text { Pair } \\
25(16 \%)\end{array}$ & $\begin{array}{l}\text { Small group } \\
81(54 \%)\end{array}$ & $\begin{array}{c}\text { Large } \\
\text { group } \\
22 \\
(15 \%)\end{array}$ & $\begin{array}{c}\text { Other } \\
2 \\
(1 \%)\end{array}$ & \\
\hline 12. & $\begin{array}{c}\text { School } \\
57(31 \%)\end{array}$ & $\begin{array}{l}\text { Computer } \\
26(14 \%)\end{array}$ & $\begin{array}{l}\text { Movies } \\
14(8 \%)\end{array}$ & $\begin{array}{c}\text { Books } \\
15(8 \%)\end{array}$ & $\begin{array}{c}\text { Orally } \\
56 \\
(31 \%)\end{array}$ & $\begin{array}{c}\text { None } \\
14 \\
(8 \%)\end{array}$ \\
\hline 13. & $\begin{array}{c}\text { Post } \\
16(9 \%)\end{array}$ & $\begin{array}{c}\text { E-mail } \\
90(48 \%)\end{array}$ & $\begin{array}{c}\text { Skype } \\
34(18 \%)\end{array}$ & $\begin{array}{c}\text { Soc. } \\
\text { Netw. } \\
44 \\
(23 \%) \\
\end{array}$ & $\begin{array}{c}\text { Other } \\
4 \\
(2 \%)\end{array}$ & \\
\hline
\end{tabular}

Source: Own elaboration.

Among the most popular activities, we can definitely place dance and sport. We can confirm that apart from dance people enjoy singing (which was not really confirmed in the research) and doing sports. They favor activities which connect people and in which they do not need to use language skills for communication that much.

It is not clear which type of sport is the favorite, a preferable one but we can state that the sports trio zumba, yoga and bowling has a slight lead. As the author, D. Gracová (2011) states "the gained knowledge has significance for health, for physical as well as the psycho-social and cultural development of a human." The first two sports (activities), I would attribute to the high percentage of women as respondents, and we can understand bowling as a sport, in which physical abilities are reduced, and we can perceive it as an activity during which we have fun, debate, 
and have a drink. Chess, as well as dance, appeared among other sports.

\section{Conclusion}

By organizing international education activities, we not only widen our personal knowledge but mainly the knowledge of people for whom we organize these events. We do not live on a deserted island but on a continent called Europe, where a multitude of nations and nationalities live. It is important to use the opportunity to become familiar with the culture, the traditions, and the customs of other nations. We have a significant number of opportunities to take part in international projects which help reduce the cultural, the social and the economic differences in Europe. Not only through a various project of the European Union, but mainly from a personal initiative, let us enable the wide surroundings to take part in these wonderful multicultural and international education activities.

In today's age of advanced ICT technology, we must not forget about electronic education for seniors at UTA. We have to enable e-learning, online, offline courses mainly to our students who live in remote areas outside the big cities (Swindell, 2000). We can talk about the large development of Online Universities of the Third Age in the United Kingdom, Australia, and New Zealand. Virtual universities which use electronic support, emails, and Skype are being established (Swindell, 2002; Tomczyk, 2015). All of these activities and actions should support the development of senior education in the world.

We agree with several authors that new technologies should not replace on-site learning. Social contacts among seniors are very important. On the other hand, we need to keep abreast of the times. The present time, as well as the near future, require the inclusion of new technologies in education and the preparation of conditions not only for students but also for lecturers and organizers. ICT technologies are constantly developing; therefore, we should have personal capacities to deal with this issue. They should affect not only organizers, lecturers but also students. In this environment, a target group of seniors is coming to us from which we expect a strong demand for new technologies. Seniors 
are not only going to expect learning about new technologies in the form of ICT courses but the fact that lecturers themselves are going to use this type of tool for significant improvement and a quality increase in the pedagogical performance in the form of PowerPoint, e-books, pdf formats, DVD demonstrations and others.

The near future is going to show that seniors are also increasing their knowledge potential and they are going to make greater demands on the educational process itself.

\section{References}

Erasmus Plus, Program Information. (2016). Retrieved from www.erasmusplus.sk/index.php?sw $=70$

Formosa, M. (2000). Older Adult Education in a Maltese University of the Third Age: A Critical Perspective. Education and Ageing, 15(3), 315-338.

Formosa, M. (2012). Education and Older Adults at the University of the Third Age. Educational Gerontology, 38(2), 114-126.

Gracová, D. (2011). Moderné formy realizácie pohybových aktivít seniorov $\mathrm{v}$ kontexte záujmového vzdelávania [Modern forms of realization in movement activities for seniors in the context of interest education]. In Záujmové vzdelávanie (pp. 100-104). Bratislava, Banská Bystrica.

Gracová, D. (2015). Vplyv pohybu a význam pohybových aktivít na vitalitu seniorov [Impact of movement and the importance of physical activities for seniors' vitality]. In Ł. Tomczyk \& Š. Chudý (Eds.), Aktywna starość w perspektywie społecznokulturowo-edukacyjnej. Společenské, kulturní a vzdělávací aspekty fenoménu aktivního stárnutí [Active old age in the sociocultural-educational perspective] (pp. 51-78). Olomouc, Kraków: Uniwersytet Pedagogiczny.

Grundtvig, Program Information. (2016). Retrieved from http://web.saaic.sk/llp/sk/_main.cfm?obsah=m_uvodna_stranka. htm\&sw prog $=5$

Huang, C.-S. (2005). The Development of a University for Older Adults in Taiwan: An Interpretive Perspective. Educational Gerontology, 31(7), 503-519.

Lemieux, A. (1995). The University of the Third Age: Role of Senior Citizens. Educational Gerontology, 21(4), 337-344. 
Selecký, E., et al. (2014). Univerzity tretieho veku na Slovensku [University of the Third Age in Slovakia]. Zvolen: Technická univerzita vo Zvolene.

Šerák, M. (2009). Zájmové vzdělávání dospělých [Interest in adult education]. Praha: Portál.

Swindell, R. (2000). A U3A Without Walls: Using the Internet To Reach out to Isolated Older People. Education and Ageing, 15(2), 251-263.

Swindell, R. (2002). U3A Online: A Virtual University of the Third Age for Isolated Older People. International Journal of Lifelong Education, 21(5), 414-429.

Swindell, R. F. (2012). Successful Ageing and International Approaches to Later-life Learning. In G. Boulton-Lewis \& M. Tam (Eds.), Active Ageing, Active Learning. Issues and Challenges (pp. 35-65). Dordrecht, New York: Springer.

Tempus, Program Information. (2016). Retrieved from http://eacea.ec.europa.eu/tempus/programme/about_tempus_en.p hp

Tomczyk, Ł. (2015). Vzdělávání seniorů v oblasti nových médii [Education of eledery in area of new media]. Praha: Asociace Institucí Vzdělávání Dospělých ČR, Praha. 
Suggested Citation: Kamińska, K. (2017). (Un)Obvious Education, or Complexities of the Polish Education Aimed at Older People. In Ł. Tomczyk \& A. Klimczuk (Eds.), Selected Contemporary Challenges of Ageing Policy (121147). Kraków: Uniwersytet Pedagogiczny w Krakowie. Doi:

\title{
KRYSTYNA KAMIŃSKA ${ }^{1}$
}

\section{(Un)Obvious Education, or Complexities of the Polish Education Aimed at Older People}

\begin{abstract}
The contemporary combination of information infrastructure with the commonly experienced transformation of knowledge created, in relation to education especially for older adults, an entirely new area of activeness. In accordance with the social awareness, education became an accessible good regardless of age. In this context, the maximal extending of the potential group of education receivers means, on the one hand, meeting the real social expectations towards so-called educational services. On the other hand, it is another challenge which the contemporary education faces. Unfortunately, the system of permanent education was not created in Poland since what is missing is both the strategy and some practical resolutions enabling old people the access to education with regards to their educational. Presently, the University of the Third Age is the only solution in the educational offer. In order to change the present status quo, what is needed is the re-definition of education and the modern perception of education and then perhaps, there will appear, the expected, by the senior citizens, module educational solutions providing them not only with the competencies but also the acknowledged certificate confirming their knowledge.
\end{abstract}

\footnotetext{
${ }^{1}$ Krystyna Kamińska, Pultusk Academy of Humanities, Poland, krystyna.danuta.kaminska@gmail.com.
} 
Key words: Ageism, Culture, Old Age, Education of Older Adults

\section{Introduction}

Contemporary processes of modernization and digitalization redefined all the elements of social space. As a result of these transformations, it is the technological challenges that create the new social reality. These transitions are associated with a slow disappearance of, on the one hand, the linear thinking in which writing had an enormous importance. On the other hand, this process is related to the traditional manners of gathering and storing the knowledge. The interactiveness of the contemporary world (both online and offline) causes to appear some newer and newer generation of systems of mass communication. Along with the development of information infrastructure, there are also drawn the new directions of education aiming at the creation of an entirely new model in terms of quality. The new technologies, however, transform not only our environment but also, they revalue our present vocational qualifications by damaging their until-now (universal) status quo. The competencies and qualifications being acquired during the period of academic education do become of little assistance with the passing of time not only in the professional career but also in day-to-day life.

It is more and more frequent that people-regardless of their age and their position in the job market - experience the need of "broader perspective of the world" so that they can comprehend the reality and the phenomena happening there in relation to their profound interpretation. Not only are the youngsters against the traditional manner of accumulating of the knowledge (identified with the defined level of education) even though it is the younger generation that points out to the necessity of changes in this area, which, in the long run, will enable them to create a modern working place but also these people who enter so-called the age of "late maturity." At the same time, these social expectations create quite specific educational behaviors being the reflection of the commonly experienced globalization of consumption and culture patterns (Bednarek, 2012, p. 77). In this context, the information society-new recipients of the educational services-definitely 
expect the new model of education which would meet the challenges of further life regardless of their calendar age.

What should change, however, is not only the role of education and the perception of it - as a common and available good for everybody despite their age- but also as a widely understood educational offer itself. Owing to this, education in the twenty-first century must exceed (beyond) the model of education formed at the end of the previous century since the digital technologies "invaded not only in our lives but also in ourselves" (Franus, 1998, pp. 204-206). In this situation, it is necessary to redefine the key concept, that is "education." Contemporary broad definition spectrum the reflection of which is the ever-multiplying terminological apparatus does make us each time to its redefinition (due to the blurred categorization criteria in relation to the "display" accepted in the particular academic discipline). The ambiguity of the term "education" (e.g., identified as a phenomenon, a process or an action) and the multiplicity of its shapes in action (including the type, form, and range) not only hinders any attempts of its unambiguous definition but it provokes to the permanent extension of its semantic field. The multidimension of education is reflected in the further attempts of the re-definition of the concept and is becoming a specific structure modeling, enabling the reshuffling of the theoretical construct into the defined practical solutions.

In the case of senior citizens, the element initiating the change in the current model of education of adults is the increasing year-by-year educational activeness of older citizens. The implication of such change is more and more intense searching by the senior citizens of some new paths of their own education. Related to older adults, the education within the frames of lifelong learning is, most importantly, the creation of such educational solutions. On the one hand, meet the expectations of this group. On the other hand, cater for its internal diversity.

\section{Lifelong Education}

Defining the outline of the education of the future, Delors indicated the necessity of the rereading of the concept of education and the institutional dimension of science by the removal of the 
defined temporal and spatial frames (Delors et al., 1996). According to Delors, education is the primary factor regardless of one's age. In this context, education of older citizens acquires a new meaning. The education whose final phase meant receiving some particular certificate is already the past. However, the future of the education is, most of all, facing the real social needs arising from the ever-changing conditions in which the contemporary society must find itself (a society which perceives the knowledge as the source of innovation and information as even non-material "product"). The education openness to change and the flexibility in creating the defined educational models which are expected by a society should consider the needs of an individual in the desire to discover oneself in the process of one's own identity but also co-create the construct of social dimension through the extension of the area of the secondary socializing (out-of-family). This specific type of integration existed in education for ages, but it was somehow restricted only for the young entering the adult life.

The abandoning of the stereotypical perception of education suggested by Delors, including the rejection of the process of scholarship the age limitations and reducing the institutional role of education does not mean separating knowledge from the roots but re-defines its new frames. Lifelong learning is the popularization of science in which the accent is to be transferred from the obligatory education and its supervision onto the variety of the educational offer depending on the expectations of the recipient.

Regardless of its shape which is adopted and the organization form (formal, informal, or incidental), lifelong learning integrates with this concept. Enriching the knowledge and improving one's own competencies throughout adult life-far from the traditional school bench but somehow with the simultaneous application of all technological possibilities which the contemporary knowledge offers to us - it is at the same time the mission and vision of the adult future education, including people entering so-called the old age. The changes to which the education of the senior citizens should be subordinated must happen collaterally with the newest civilizational achievements. 


\section{Old Age and the Attempts of Its Re-reading}

The afterthought on the old age in the contemporary academic discourse is attempted to be drawn by the new direction of narration which through the changes happening in culture will, in an accurate manner, reunite the image of the old age with its reality. It is the new narration which rooted in the individual experiencing the old age-either by themselves or close relatives - that can give the assumption to the reinterpretation not only of the concept but also the extracting of the old age as a social phenomenon. This change is somehow a consequence of a slow "disappearance" and old paradigm in the description of an old age resulting from the defined linguistic correctness accepted in some analyses. It was reflected in the specific blurring of the traditional terminological grid. The new theoretical construct built in the academic discourse causes that the old age undergoes a particular metamorphosis in the next, even-newer attempts of its re-reading. This change is accompanied by the development of the "intellectual" analytical tools applied in the (re-)defining the concept of the old age. Having reached a certain age, many people do not approve the stereotypical image of a senior citizen (sick, weak, and inefficient) and thus demanding care and, therefore, undertake some actions modifying their image in the social awareness as well as the protective ones with the aim of preserving one's subjectivity.

The appearance of some new terms in the terminological grid creating the terminological frames of the old age, e.g., ageism, slowly changes its narration. Butler, who introduced this term indicated the existence of a set of beliefs, predictions or stereotypes which determine the image of (older) person depending on their calendar age (Butler, 1975, p. 35). Ageism, however, focuses the attention on both the attitudes and the stereotypes affecting the biological differentiating the people owing to their age concentrating on the competencies possessed by the senior citizens (Szukalski, 2004). However, the competence model of the old age includes two basic elements: the responsibility of old people for themselves and the ability to deal with the difficulties. A crucial part of this model is education itself. Education, however, facilitates the acquisition of the 
distance to reality, constitutes a particular "foundation to create the conditions and possibilities of lifelong learning, learning until the old age, learning through the old age, and learning at the old age" (Malec, 2011, p. 25).

The old age is a natural stage of completion of the adult life, which, unlike childhood and the youth, is a period definitely prolonged with time. Experiencing the old age in the process of an active ageing which is accompanied with the pro-educational attitude, not only improves the quality of life but also teaches the conscious control over it. The way we experience the old age depends on many factors. These factors mark some specific border points of an older adult's functioning. The old age is this phase of life which characterizes many variables providing the individual image of an old person. Similarly, the process of getting old can be passing in various forms depending on the individual mental features and the conditions of the social-cultural environment. Moreover, the retirement is not always associated with the beginning of the old age. Also, the attitude of old people considering their own ageing can take various shapes. It results from the defining some strategy of actions related to one's own. "In the opinions of senior citizens, the concept of successful ageing is perceived through the attitude and the strategy of dealing with, whereas the life satisfaction is identified with the satisfaction over the present life along with the satisfaction over the past experiences" (Halicka, 2004. p. 30).

The concept of active ageing appeared in the 1960s and it "means keeping the physical fitness and the ability to work professionally (...) as long as possible" (Richert-Kaźmierska, Forkiewicz, 2013, p. 128). The widely understood concept of active ageing is also some kind of working strategy; it means the active part in the social-cultural and economic life (nationally or locally). Among many of the conditions determining the quality of life of older citizens, we can distinguish not only their rights but also their duties, including the right to lifelong learning as well as the obligation to undertake the educational chances (Jurek, 2012a, p. 11). In this way, the concept of active ageing is integrated with the educational activeness of older adults. It allows the old citizens to enrich their knowledge of the world, to widen their former 
interests or to discover new passions as well as to re-interpret the former experiences from their life.

The concept of active ageing does not only display the new image of an old person but also it constitutes the counter-balance for the traditional presentation of the old age since it positions old people within the society in a different way (WHO, 2015). However, the continuing revalorization of the old age in the social meaning along with the increasing year-by-year number of people who are turning the border between maturity and older age has caused the increase in the seniors" awareness of their rightful (due to their age) social rights, which has led to the constituting of some new rights, including the right to education.

In this context, the theory of active, successful ageing by Maddox (1964) points out that the senior citizens still want to be active despite their life situations which are conditioned in terms of health and occupation. In the theory of personality in the process of ageing and old age by Neugarten (1964) and the cognitive theory of personality and ageing by Thomae (1992), it is old people that build the image of their old age. In the assumption accepted by Neugarten, the type of adaptation to old age draws the direction of the old person's activeness. However, according to Thomae, the most important factor in experiencing the old age is the self-perception as the person getting old. Therefore, accumulating of experiences throughout one's own life can also be "successful" in the self-creation at the old age and depending on one's own engagement, one can have the influence over the reorganization of the surrounding reality. According to Bromley (1966, pp. 105-110), the constructive attitude which is characteristic of life optimists and the people interested in the future does not change with the age. Following this way of thinking, the personality formed throughout the years is presented in the accepted attitude towards the old age and its displays, whereas the knowledge of one's own predispositions and possibilities is a unique guide to the type of activeness undertaken by old people. 


\section{Linguistic Rehabilitation of the Old Age}

As a rule, the identification of the old age takes place generally by the application of the criteria of the age being reached, therefore, to describe it, the following terms are used: older age, the late age or more metaphorically "the autumn of life" (sometimes the criterion related to retirement is used, e.g., the retirement age.) It is not always that the verbal terms can be treated as synonyms (e.g., a pensioner does have to stand for a person at an old age). The lack of precision not only in the common application of the terms related to old people but also in the academic terminology causes some terminological simplification and specific verbal creations to spread, such as the term of "late maturity" (Czekanowski, 2014, p. $58)$.

The aspect of placing the knowledge on the old age in the linguistic context also has its own connotations in the perception of old people. The manner in which we talk about them is the indicator what we think about them. The imagination of the old age and the way we talk about the aged (especially in the colloquial speech) also has its social consequences. Language, however, is a social phenomenon but we also learn it through our participation in the social practice. This co-operation is distinctly heard in many commonly used expressions (often not objective), which are applied to same old people. We sometimes more or less consciously use one of the terms or another to display what we think of the old age. The verbal picture of the world reflects "diverse verbalized interpretation of reality grasped in the form of opinions (...) [implied] by some verbal forms preserved on the level of social knowledge, beliefs, myths" (Bartmiński, 2006, p.12). The verbal awareness is continually modified and transformed under the influence of new experiences and events. Therefore, the verbal constructs, created and used by the speaker allow to learn their mentality and the manners of the perception and contextualization of the world (Bartmiński, 2006, p. 15). At the same time, the language (leaving the individual aspect) constructs and constitutes the social life going into all spheres of life and becoming a particular foundation of the changes happening in the commonly understood reality. However, the defined categories and their organization are the basis to mapping 
the meaning of the words, while the surrounding speech places the precise mapping performed for particular words (Bokus, Shugar, 2007, p. 153). Therefore, the specific limitations of a language at the same time become the borders of thinking about the old age. The expressions which we use to talk about old people and the old age results from the image of reality defined by us. Its outline arises not only through the influence of experiences, knowledge, or emotions but also pretty frequently from the reference to the stereotype which often determines the vocabulary applied in the verbal contacts.

Expressing usually the positive attitude towards the senior citizens, we use the terms: grandfather, senior, the grand old man-mainly related to a family member. Presenting the negative emotions, we use the other words: gaffer, wrinkly, old-timer, old geezer, old boy, or old fossil. In this polarization, some asymmetry can be perceived. The predominance of the pejorative words (as a grandfather and an old man can be valorized negatively depending on the context of the utterance,) indicates rather negative social perception of the old age by the majority of the population. This far-fetching simplification results from the conscience-stricken depreciation of the old age which presently "has become in gremio deprived of its eternal social function which is the cross-cultural transfer of cultural contents" (Kamińska, 2016, p. 135) for the sake of the specific cult of youth which comfortably has settled in our culture. The verbal perception of the old age presents how the concept of the old age has been determined and "filtered" by language. This (double) verbal determination has the influence on shaping the social reception of the old age. At the same time, the new sphere for new narration is being created. The narration in the form of a structured modeling, rejecting the polarization for the sake of accumulations created as a result of specific neologisms, e.g., late maturity or by acceptance and the application of new terms (e.g., ageism). It is perhaps then that the (enriched) language which we shall use to describe the act of getting old will cause the transfer of some of the terms in the praxis side and will not be out of social, positive experience (Zdziarski, 2014, p. 83). 


\section{Learning to Be}

"Learning to be" - the title of the report by Edgar Faure in 1972 considering, among others, the future of education - is one of the four then-presented essential pillars of its further development. The remaining pillars were: "learning to do," "learning to know," and "learning to live." They jointly provided the directions of changes in relation to lifelong learning (Faure et al., 1972). The reference to them after many years indicate that they have not lost anything of their importance in relation to the education of old people. As a theory, the authors of the report assumed, however, the universal access to education regardless of age. The undertaken by old people the educational activity not only counter-acted the social reclusion but most importantly, it strengthens the independence and one's autonomy as well as constitutes a particular remedy to be happy. Whereas "participation in educational programs and enterprises has some therapeutic value for the aged. It allows them to preserve the intellectual ability which in turn influences hindering the biophysical processes of getting old" (Richert-Kaźmierska, Forkiewicz, 2013, p. 130).

In this perspective, education directed at seniors should have taken its place in the offer of lifelong learning (dedicated to people who are no longer subjected to scholastic processes). However, the contemporary connotations of this access to education are completely different than initially assumed. For years, old people were not perceived as the recipient of widely understood educational services. Moreover, the rapid development of the concept from the 1970s of establishing the Universities of the Third Age as the basic (and at the same time only) place of the comprehensive education for the seniors did minimize completely any other forms of education in the offer of permanent education. "Learning to live" in the context of "lifelong learning" does not impose any rigid functional forms of the education of old people, including its institutionalization. On the contrary, it is to fulfill the role of the seniors' further integration with the society.

The University of the Third Age (U3A) exerted an important role in separating the specific educational path devoted to old people in many countries, e.g., in France, in Belgium, in 
Spain, in Canada and the further phases. However, in Poland, the University of the Third Age (regardless of the leading organ) preserved some stereotypical way of perception of the education of old people being far from the initial pattern. The first U3A was founded in Toulouse owing to the initiative of Pierre Vellas within the then-present university (Vellas, 1977). U3A was an academic center whose actions were dedicated to old people. "The characteristic features of the French model are a high level of didactics, academic research activities with the simultaneous diversity of organizational forms" (Ziębińska 2007, p. 160). The idea of U3A conception was closely associated with the informal education at the academic level. The reference to university in the name U3A increased the importance of the undertaken educational initiative. In Toulouse, the running of U3A within University allowed implementing a certain standard of educational services whose guarantee was the staff comprising mainly of the academic lecturers. Moreover, running and the administrative-legal supervision of the university provided U3A with a proper status. Soon, in France there appeared similar centers, e.g., at University in Nice and University in Caen. With time, this education solution a la France whose recipients were the seniors were transferred to Belgium and Switzerland. This dynamically developing movement for the sake of old people education in 1975 led to establishing the International Association of Universities of the Third Age (Steuden, 2011, p. 93).

This solution was also transferred to Poland. The first University of the Third Age in Poland was founded in 1975 owing to the initiative of Halina Szwarc within the Postgraduate Centre of Medical Education in Warsaw (Szwarc, 1995). However, with time the Polish adaptation of the French model underwent further transformations and lost many of Vellas' idea. Most importantly, what was changed was the primary administration-legal attribution. U3A can be founded and run by universities and activate the senior citizens, but they also can operate under the patronage of associations and foundations offering the activities of popular science as well as within the statutory operations of various institutions of cultural character, e.g., libraries or local culture centers, and even at care facilities, including day-care 
centers, social care centers and similar (Jachimowicz, Nalepa, 2012 , p. 10). This caused that the concept of U3A being treated as superficial and in many cases the decrease in the quality of educational services (Borczyk, Nalepa, Knapik, Knapik, 2012). The quality differences are visible already at comparing the Polish educational offer and its factual level with the proposals related to educating older people in other countries, e.g., in Italy (Czerniawska, 2004, pp. 169-182) or in Switzerland (Kamiński 2016). The analysis of the contents of various offers of Polish centers - being named the University of the Third Age - when compared to the assumptions of the French model (of enabling the informal lifelong learning of old people at the academic level, preparing the proper staff to work efficiently with the senior citizens or running the research considering the medical, legal or mental-social problems) displays that the present proposals related to activating the seniors are relatively close to the British model in which the stress is placed on the self-education and the actions supporting old people. The British model (also named Cambridge model) refers to so-called self-help in which education has more practical character (that is taking advantage of life experiences of the people with similar problems rather than intellectually challenging and broadening the horizons of possessed knowledge). Even though this model is more democratic, it is not favored by all senior citizens (Rivard-Lacroix, 2009). Comparing the Polish educational offers for old people with similar proposals in other countries in which the Universities of Third Age also run, we can notice a great difference, e.g., in Switzerland. There "the most popular forms of education for old people are Universities of the Third Age. (...) Academic professors give the lectures, and the subject matter is mainly academic and highly diverse, e.g., psychology, economy, theology, medicine" (Kamiński, 2016, p. 259).

Polish U3A, perhaps not to be blamed itself, concentrating mainly on the group of older people, preserve the age-related social segregation, separating the education of the seniors from the traditional educating of the adults not only in the administration legal or spatial sense but also in relation to the program. The lectures offered to the seniors are predominantly referring to the 
problems which can only interest older people, similarly to the subject matter of the common classes (e.g., U3A proposals in March 2017: seniors' meeting the manager of Social Insurance Institution, first-aid course "Active Senior"-meeting the firefighters, meeting related to International Women's Day-fee 10 PLN, practicing Nordic Walking, a lecture: "Senior's Modern and Safe Finances," a workshop: "Senior's Modern and Safe Finances"-working in 10-person group; a lecture and a workshop run by the National Federation of Associations of Universities of the Third Age). This artificial division from the rest of the society and also placing the U3A in local cultural centers and day-care centers only deepens the further social degradation of the senior citizens (Klimczuk, 2012). The uneven treating regarding education instead of supporting the feeling of their own value with the seniors only preserves the mechanisms of their depreciation. Lack of everyday contact with these people in the process of education with the rest of society and the constant contact with the same group as well as the subject matters (limited to the issues related to the processes of ageing) only increases the alienation. "It is frequent that U3A are set up and managed by older people who are the leaders in the seniors' local environment" (Borczyk, Zacłona, 2014, p. 17). However, not all of them can keep (despite their willingness) the pace of the happening changes and not all of them are properly, theoretically prepared in terms of andragogy or gerontology or practically, e.g., animator of culture or resulting from the prior own educational experiences in teaching others.

Against the appearances, introducing the segregation (understood as positive discrimination) through the creation of Polish network of U3A and creating the small local educational centers for older people (out of institutionalized system of lifelong learning: professional advancement centers, extra-mural education at the primary, secondary and higher level, postgraduate studies, and similar) additionally favored the preservation of the negative stereotype of old persons in society. Therefore, it is necessary to build the awareness of the Polish society the new image of the old age. In Poland, all displays of discrimination towards the aged could be, and at the same time should be leveled with the use of education. Education on the one hand dedicated to the society, and 
on the other hand to the senior citizens as crossing the borders dividing both worlds is necessary so that "the old age-friendly culture" becomes a reality (Szukalski, 2016, pp. 50-51).

For many years, the education of the adults realized within the lifelong learning was significantly associated with the administration legal solutions allowing for the completion of knowledge. It was related to the development of educational solutions aiming at the advancement of the education level of the evening education (at the secondary level) or extra-mural studies and also the professional advancement in forms of courses, workshop, or post-gradual studies. However, it is not the education the senior citizens expect. Lifelong learning directed at this group of recipients should, on the one hand, consider their former educational experiences and the present needs in terms of acquiring new competencies (knowledge and abilities) and on the other hand exclude any barriers limiting the access to education. It was long ago that changed the traditional recipient of widely understood education of adults in the educational sphere. Thus, the concept of lifelong learning itself should transform.

\section{In Search of the New Model of Education for Senior Citizens}

The paradigm of information technology whose key matter constitute the social processes exceeding the economy and disavowing the former role of natural resources as the developmental factor. Presently, the primary "source" which makes the economic development dynamic is the information which simultaneously provides us with the frames of the society being created (Castells, 1996). In this combination, it is not the product (information) that it is important - it is its contents and the transfer within the borders of the current scene. These elements of contemporary economy create a specific network "of completely different, non-linear spatial logic."

In the digital era, the traditional model of university studies dating back to the thirteenth and fourteenth centuries as well the present state for the recent two centuries is slowly abandoned. The specific microcosms of a university (in which there were a master and the knowledge included in the world of books) have ceased to meet the needs of a contemporary university. Simultaneously, the 
system of education is no longer associated with "proper" professional training. The transformation of knowledge in the information society takes the various shapes, and at the same time, it influences the education. This state causes that both society and an individual have some different expectations when it comes to education. "The process of learning always has the individual and biographical character (...) however, in the society which is learning the individual has got freedom considering what they want to learn and how they want to learn, which is becoming the key factor of the contemporary education of adults" (SolarczykAmbrozik, 2014, p. 275). Thus, old people have an absolute right to such education.

\section{Open University}

Creating the concept of the Open University is most importantly the answer to still demanded from the society the need of institutionalized education, allowing for lifelong learning. Simultaneously, it is an attempt to combine the formal with informal education, that is reaching beyond the traditional frames of education "divided" into subsequent levels and phases. Open Universities are open as a part of technical universities (e.g., the University of Science and Technology in Krakow (AGH), Poland), humanities (e.g., the University of Warsaw, Poland) or environmental university (e.g., the Warsaw University of Life Sciences, Poland). By attributing it to higher education, the Open University keeps the values of academic education in its educational offer. Additionally, eliminating the recruitment limitations and the choice of any area of education and its range enables its listeners (regardless of age and prior level of education) both the realization of one's own educational aspirations and getting some solid competencies.

Simultaneously, its defined organization-legal form enables educating less formally and allows for creating the solutions of diverse forms. Education takes place not only intramural but also extra-mural, the latter even taking the possibility of the distance learning. The operational standards of the Open University functioning (including the defined legal regulations confirming the acquired knowledge and competencies) will allow for the creation 
of educational services directed at various recipients and meeting their expectations. The participation in lectures is beneficial when it comes to the updating the knowledge as well as enriching it. At the Open University, apart from the broadening of theoretical knowledge, one can acquire new practical abilities, thus multiplying one's own competencies.

The Open University is perceived as an educational solution oriented at the future and the future education (apart from the period of obligatory schooling). The idea of lifelong education and the individual building of one's own education path is integrated with its vision and mission. However, the educational offer supported with author programs of academic lecturers is the guarantee of the education quality. The openness is not only the possibility of meeting the expectations of some particular recipients and organization of special lectures but the constant readiness to change. The Open University really is an "open" place not only for new educational initiatives but also the meeting place for the world of science, culture, and art. It organizes some debates with the representatives of the academic, artistic environments or various political parties.

It seems that it is the very Open University that is the (educational) response to the educational needs of old people. Especially the ones who would wish to begin their academic education in the form of regular meetings. Moreover, the ones who favor the interpersonal contacts. For one group of people, this type of education will be the possibility of completion of the former educational plans and the development of interests, for the other one the inspiration to further activeness, e.g., of social type. Yet, some other will treat the participation in as some encouragement to make an advancement of one's own particular qualifications (the Open University with regards to its courses and training provides its listeners with some certificates confirming the participation and stating the knowledge and abilities as well as qualifications, providing the persons have passed the necessary examinations, e.g., knowledge of foreign languages). The professional skills achieved at the Open University can be of some assistance to the seniors wishing to return to the job market if they feel such a necessity. 


\section{Asynchronous Education (Also Known As Asynchronous Teaching)}

The model of learning within the frames of asynchronous education is the changed context of education functioning. It allows for the education at any place and time. Simultaneously, the extended, often virtual educational sphere-applying the modern information technologies in the process of teaching and learning - it is always a chance of education for older adults (who are not always able to take part personally in the lectures, e.g., due to their health issues). In the asynchronous education, the computer-related support of the educational process was based on the contact online and can be of an internal character, within socalled networks as well as external, by the application of electronic mail, participation in the internet discussion forum or audio-visual conference (Juszczyk, 2003, pp. 862-866).

Asynchronous education becomes the future of the education aimed at the seniors, especially the ones who have got the positive attitude towards the modern technologies in relation to the prior experiences with their application. It ensures, so necessary in the older people's education, the flexibility with reference to the educational contents and the place in which the educational process is to be realized. Simultaneously, in the asynchronous education one can use some positive features of old people, e.g., self-discipline, ability to manage one's time as well as acceptance to realize some particular exercises following the instructions.

The application of the interactive possibilities of education in asynchronous education along with the increase in readability of the new contents through pictures facilitates the transformation of the accumulated information. Active building of the knowledge, an individual verifying of the sources of information as well as the possibility of rapid exchange of information, on one hand, strengthens the feeling of self-realization and on the other, one's functioning in the network increases the number of contacts with people of diverse ages which with time can move from the virtual life to the real life.

Creating the modern form of distance learning aimed at not only older people is associated with an individual and also 
collective co-participation in the educational network. However, it has to be accompanied on one hand with a strong internal motivation of each person as they learn for themselves, and on the other the proper set of tools, e.g., as e-books or materials to be applied at e-learning and constituting the completion of the traditional model of education. E-learning is perceived as a type of distance education, supported in the process of education by the modern information technologies. (This type of education has made a long way from education thanks to radio in some inaccessible areas in Australia through diverse educational solutions using television to the subject matter online presentations at selected platforms and interactive contact with the lecturer). Using e-learning a person learning by oneself decides on the time and pace of work and the range of the knowledge being acquired.

Year-by-year, e-learning is more and more popular (not only at the higher level of education) thus becoming the most modern tool of contemporary education. The process of education supported with modern technologies does facilitate the communication of persons while learning (including e-mail). Getting the information from the network, including the participation in discussion groups or writing a blog increases not only the availability of many sources but also it facilitates their ultimate selection. In the educational practice, also the so-called mixed mode is applied. Then, the direct contact with the contents sender is extended by the lectures in form of (audio-video) conference, or sharing the materials online (at universities there are created so-called environmental systems of information where through the graphical interfaces various information is transferred to particular users: from registration to selected lectures through the information on time and place of particular lectures, to sharing the necessary materials).

The additional advantage of e-learning in undoubtedly the possibility of the immediate access to the educational material and the possibility of the multiple uses of its selected fragments. In the education of older people, e-learning can prove a miraculous tool. It allows for pausing the text at any place or going back to some former fragments as well as the individual enriching of the 
elaboration or its modification. Therefore, e-learning properly composed in the whole model of lifelong learning allows for the participation in the educational process in which the age limitation will (finally) cease to have any importance.

\section{Conclusion}

"Educational actions among the old citizens are one of the most important elements of their life quality improvement" (Halicki, 2009 , p. 208). In his considerations on the strategies of actions concerning the problem of the population's getting old, Steuden refers to the "Madrid International Plan of Action on Ageing" (2002), the document in which the program of actions towards old people was proposed by providing the directions of support. The first one considered the widely understood old age and the preparation and promotion of the programs of optimal ageing, including the definition of potential possibilities and abilities of learning. The second one referred to the quality of life during the period of ageing perceived through the standpoint of health and well-being. What it indicated was the meaning of the lifelong learning and the necessity of "grasping" the knowledge for the sake of up-keeping the cognitive abilities which indirectly influence one's fitness. However, the third direction was oriented at the creation of the friendly and supportive environment in which old people could feel safe (Steuden, 2011. pp. 28-29).

Active ageing which is experienced by many seniors not only worldwide but also in Poland proves that the former futuristic visions of their education regardless of their calendar age are becoming more and more real. Old people themselves ceased to refrain from education. Moreover, the research results underline that the more educated they are, the more willing they are to learn further (Pakuła, 2010, p. 180). While the educational activity undertaken by them strengthens their internal motivation stimulating both to new educational challenges and to entering the new social roles as well.

Lifelong learning in the context of old people is of significant meaning nowadays. The demographic changes clearly indicate that the generation of the post-war population boomers will soon begin to retire, and for many of its representatives it will 
not mean retreating from the active life (Pakuła, 2010, pp. 38-39). Many of them will be characterized with so-called competence model of old age defined by the pro-active adaptation to the old life providing them with the greater feeling of autonomy, the feeling of perpetration and the sense of an individual representation in various areas of their own functioning. Old age citizens are better and better at understanding the necessity of lifelong education as some of them have already been convinced of its effectiveness (Pakuła, 2010, p. 184).

Due to the mentioned above, behind the frames of a stereotypical image of the old age appears a new portrait of a person at the old age. The person who will have some other-not necessarily new-social expectations but they will announce them with reference to their modified needs. One of them can be the possibility of education. The lifestyle which they will wish to live is, however, is inextricably with the lifelong learning. The completion of the educational need will be felt regardless of one's age, the present level of education or professional experience. Such matter of fact will, on the one hand, impose a change in social perception of the old age, and on the other hand, will initiate the process of changes in the present model of education which was once created for old people. No matter if we are going to name education the recipient of which will be old people the lifelong learning, permanent education, or the education for the adults, what is the most important is the re-define the frames of their quality model.

This new area of the considerations on the education of the senior citizens in which both the Open University and asynchronous education (including e-learning) play a vital role yet has not become significantly popular in Poland with regards to the existing national educational solutions dedicated to old people. However, the concept of the Open University is beginning to operate at some academic centers in Poland. Perhaps, their achievements in this field, as well as the great number of attendance, will encourage other universities to follow. Nevertheless, lifelong learning in the context of education of old people remains closed to so-called asynchronous education and wider application of e-learning. Implementation of these solutions 
will not be possible unless there is a change in the way of thinking about the cognitive potential and possibilities of the senior citizens by people who are directly engaged in creating the educational offer and multiplying the solutions in the educational area for the aged. Undoubtedly, the changes are inevitable, and they should happen in relatively short time. Should that not happen, old people's meeting the contemporary education needs will remain difficult, as the educational offer prepared for them remains in the "era of chalk." Due to this, the educational transfer of old people in the twenty-first century so that they would be able to take advantage of all the possibilities of the dynamic technological development is still the distant future. Learning how to use a computer is just the first step to asynchronous education and not the final contact with new technologies. What should be done at the moment is to create some applications for the senior citizens in the form of so-called educational agents which will allow old people (with reliant mobility but still intellectually active) to learn thanks to the distance learning. The implementation of a virtual educational (pedagogical) help will enable them the individual use of the newest solution within the asynchronous learning and will make them feel safer during the educational process itself. The pedagogical agent would also introduce the social context into the educational process increasing not only the engagement of old people in terms of educational activities but also the beneficial effects of education by giving them the feeling of safety while learning with the support of a computer, e.g., as better-learnt knowledge (Landowska, 2008, p. 86).

\section{References}

Association des universités de 3e âge du Nouveau-Brunwick, Université de Moncton. (2013). Réflexions de l' Association des universités de $3 \mathrm{e}$ âge du Nouveau-Brunwick en matière de formation continue [Reflections of the Association of New Brunswick Universities in continuing education]. Retrieved from http://web.umoncton.ca/uta/Association/Documentation - PDF et DOC/Réflexions de l'AUTANB - Formation continue.pdf 
Bartmiński, J. (2006). Językowe podstawy obrazu świata [The linguistic basics of the image of the world]. Lublin:

Wydawnictwo Uniwersytetu Marii Curie-Skłodowskiej.

Bednarek, J. (2012). Multimedia w ksztatceniu [Multimedia in Education]. Warszawa: Wydawnictwo Naukowe PWN.

Bokus, B., \& Shugar, G. W. (2007). Psychologia języka dziecka stare i nowe pytania, nowe dane, nowe hipotezy [Child language psychology — old and new questions, new data, new hypotheses]. In B. Bokus \& G. W. Shugar (Eds.), Psychologia języka dziecka - osiagnięcia, nowe perspektywy [Child language psychology - achievements, new perspectives] (pp. 9-32).

Gdańsk: Gdańskie Wydawnictwo Psychologiczne.

Borczyk, W., \& Zacłona, Z. (2014). Profesjonalny Uniwersytet

Trzeciego Wieku: Program edukacyjno-aktywizujacy UTW. Wybrane zagadnienia [Professional University of the Third Age: Education and activation program: Selected issues]. Nowy Sącz: Ogólnopolska Federacja Stowarzyszeń Uniwersytetów Trzeciego Wieku.

Borczyk, W., Nalepa, W., Knapik, B., \& Knapik, W. (2012).

Standardy działania uniwersytetów trzeciego wieku w Polsce [Standards of operation of Universities of the Third Age in Poland]. Nowy Sącz: Wydawnictwo Ogólnopolska Federacja Stowarzyszeń Uniwersytetów Trzeciego Wieku.

Bromley, D. B. (1966). The Psychology of Human Ageing. Baltimore, MD: Penguin Books.

Butler, R. N. (1975). Why Survive?: Being Old in America. New York, NY: Harper \& Row.

Castells, M. (1996). The Rise of the Network Society. Oxford: Blackwell Publishers.

Czekanowski, P. (2014). Wieloznaczność określeń odnoszących się do ludzi starych [The ambiguity of the terms referring to old people]. In B. Szatur-Jaworska (Ed.), O sposobach mówienia o starości. Debata. Analiza. Przyktady [About ways to talk about old age: Debate, analysis, examples] (pp. 52-60). Warszawa:

Biuro Rzecznika Praw Obywatelskich.

Czerniawska, O. (2004). Nowe instytucje oświaty dorosłych we Włoszech [New adult education institutions in Italy]. Edukacja Dorostych. (1-2), 42-43. 
Delors, J., \& et al. (1996). Education: The Treasure within: Report to UNESCO of the International Commission on Education for the Twenty-first Century: Highlights. Paris: UNESCO Publishing.

Fabiś, A., Muszyński, M., Tomczyk, Ł., \& Zrałek, M. (2014). Starość w Polsce. Aspekty spoleczne i edukacyjne [Old age in Poland: Social and educational aspects]. Oświęcim: Wydawnictwo Państwowej Wyższej Szkoły Zawodowej im. rotmistrza Witolda Pileckiego.

Faure, E., Herrera, F., Kaddoura, A.-R., Lopes, H., Petrovsky, A. V., Rahnema, M., \& Ward, F. C. (1972). Learning to Be: the World of Education Today and Tomorrow. London: UNESCO, Harrap.

Franus, E. (1998). Wstęp [Introduction], Haraway, D., Manifest cyborga [Cyborg manifesto]. Magazyn Sztuki. (17), 1.

Halicka, M. (2004). Satysfakcja życiowa ludzi starszych. Studium teoretyczno-empiryczne [Satisfaction of older adults:

Theoretical-empirical study]. Białystok: Akademia Medyczna.

Halicki, J. (2009). Edukacja w starości jako działanie poprawiające jakość życia seniorów [Old-age education as a measure to improve the quality of life for seniors]. Chowanna. (2), 204212.

Halicki, J. (2014). Zaspokajanie potrzeb edukacyjnych jako czynnik aktywnego starzenia się [Satisfying educational needs as an active ageing factor]. In P. Szukalski \& B. Szatur-Jaworska (Eds.), Aktywne starzenie się. Przeciwdziałanie barierom [Active ageing: Counter barriers] (pp. 142-152). Łódź: Wydawnictwo Łódzkie.

Jurek, Ł. (2012a). Aktywne starzenie się jako paradygmat w polityce społecznej [Active ageing as a paradigm in social policy]. Polityka Społeczna. (3), 8-12.

Jurek, Ł. (2012b). Wykluczenie społeczne osób starszych - analiza problemu z perspektywy kształcenia ustawicznego [Social exclusion of older adults: Analysis of the problem from the perspectives of lifelong learning]. In J. Gulanowski (Ed.), Uniwersytet Trzeciego Wieku - przeciw wykluczeniu, dla społeczeństwa wiedzy [University of the Third Age: Against exclusion, for the knowledge society] (pp. 101-114). Wrocław: Wydawnictwo Uniwersytetu Wrocławskiego.

Juszczyk, S. (2003). Kształcenie asynchroniczne [Asynchronous learning]. In T. Pilch (Ed.), Encyklopedia Pedagogiczna XXI 
wieku [The twenty-first century pedagogical encyclopaedia], t. 2 (pp. 862-866). Warszawa: Wydawnictwo Akademickie „Żak”. Kamińska, K. (2016). Powrót „zapomnianego” autorytetu, czyli reaktywacja kapitału kulturowego i kreatywnego ludzi starszych [The return of "forgotten" authority, that is the reactivation of cultural capital and creative old people]. In Ł. Tomczyk, C. Határ, \& N. Špatenkowa (Eds.), Edukacja i kompetencje seniorów [Education and competence of seniors] (pp. 129-146). Kraków-Nitra-Olomouc: Katedra Pedagogiki Społecznej i Andragogiki. Uniwersytet Pedagogiczny w Krakowie.

Kamiński, T. (2016). Jak robią to inni? System wspierania seniorów w Szwajcarii [How do others? Senior citizen support system in Switzerland]. In P. Broda-Wysocki, A. Dylus, \& M. Pawlus (Eds.), Dyskryminacja seniorów w Polsce. Diagnoza $i$ przeciwdziałanie [Discrimination of seniors in Poland: Diagnosis and countermeasures] (pp. 247-263). Warszawa: Wydawnictwo Naukowe UKSW.

Klimczuk, A. (2012). Kapitat społeczny ludzi starych na przykładzie mieszkańców miasta Białystok [The social capital of old people on the example of inhabitants of the city of Biatystok]. Lublin: Wydawnictwo Wiedza i Edukacja.

Korzan, D. (2003). Kształcenie ustawiczne - przegląd literatury [Continuing education - literature review], Rocznik Andragogiczny. Retrieved from www.korzan.edu.pl/pdf/ustawiczne.pdf

Kurek, J. (2009-2010). Uniwersytet Otwarty. Studenci nietradycyjni [Open University: Non-traditional students]. Gazeta Uniwersytecka. (Grudzień-Styczeń).

Landowska, A. (2008). Rola agentów edukacyjnych w środowiskach zdalnego nauczania [The role of educational agents in remote learning environments]. Zeszyty Naukowe Wydziału Elektroniki $i$ Automatyki Politechniki Gdańskiej. (25), 83-86.

Maddox, G. L. (1964). Disengagement Theory: A Critical Evaluation. The Gerontologist. (4), 80-82.

Malec, M. (2011). Poszukiwanie recepty na starość - wyzwaniem dla edukacji dorosłych. Refleksja nad uczeniem się starości przez całe życie [Search for recipes for old age - a challenge for adult education: Reflection on the learning age throughout life]. In M. Malec (Ed.), Edukacyjne, kulturowe i społeczne konteksty 
starości [Educational, cultural and social contexts of old age]. Wrocław, Wrocław: Oficyna Wydawnicza ATUT Wrocławskie Wydawnictwo Oświatowe.

Nawrocka, J. (2013). Społeczne doświadczenie starości: Stereotypy, postawy, wybory [Social experience of old age: Stereotypes, attitudes, choices]. Kraków: Oficyna Wydawnicza "Impuls".

Neugarten, B. L. (1964). Personality in Middle and Late Life:

Empirical Studies. New York, NY: Atherton Press.

Pakuła, M. (2010). Postawy osób starszych wobec edukacji. Studium teoretyczno-diagnostyczne [Older people's attitude to education: Theoretical-empirical study]. Lublin: Wydawnictwo Uniwersytetu Marii Curie-Skłodowskiej.

Richert-Kaźmierska, A., \& Forkiewicz, M. (2013). Kształcenie osób starszych w koncepcji aktywnego starzenia się [Training of older people in the concept of active ageing]. In A. Rączaszek \& W. Koczur (Eds.), Problemy edukacji wobec rozwoju społecznogospodarczego [Problems of education towards socio-economic development] (pp. 127-139). Katowice: Wydawnictwo Uniwersytetu Ekonomicznego.

Rivard-Lacroix, C. (2009). Université de Troisième Âge au Quebec et ailleurs [Third Age University in Quebec and elsewhere]. Retrieved from www.aeutaq.ulaval.ca/fileadmin/Documents/UTA_Presentation _ppt/Site_UTA_PowerPoint_compresse.pdf

Seredyńska, D. (2013). Dyskursy edukacyjne o starości w naukach humanistycznych i społecznych. Analiza konferencji ogólnopolskich [Educational discourses about old age in the humanities and social sciences Analysis of national conferences]. Bydgoszcz: Wydawnictwo Uniwersytetu Kazimierza Wielkiego.

Solarczyk-Ambrozik, E. (2014). Oświata dorosłych w zmieniającej się rzeczywistości - między nowoczesnością a postmodernizmem [Education of adults in the changing realitybetween modernity and postmodernism]. In W. Ambrozik (Ed.), Edukacja. Uniwersytet. Oświata dorosłych. Studia z pedagogiki ofiarowane Profesorowi Kazimierzowi Przyszczypkowskiemu [Education, university, adult education: Study of the education offered to Professor Kazimierz Przyszczypkowski] (pp. 268- 
281). Poznań: Wydawnictwo Naukowe Uniwersytetu im. Adama Mickiewicza.

Steuden, S. (2011). Psychologia starzenia się i starości [Psychology of ageing and old age]. Warszawa: Wydawnictwo Naukowe PWN.

Szukalski, P. (2004). Uprzedzenia i dyskryminacje ze względu na wiek (Ageizm) - przyczyny, przejawy, konsekwencje [Agebased prejudice and discrimination - causes, manifestations, consequences]. Polityka Społeczna. (2), 8-12.

Szukalski, P. (2016). Kulturowe uwarunkowania (auto)dyskryminacji ze względu na wiek [Cultural conditioning (auto)discrimination on grounds of age]. In P. Broda-Wysocki, A. Dylus, \& M. Pawlus (Eds.), Dyskryminacja seniorów w Polsce. Diagnoza $i$ przeciwdziatanie [Discrimination of seniors in Poland:

Diagnosis and countermeasures] (pp. 39-52). Warszawa:

Wydawnictwo Naukowe UKSW.

Szwarc, H. (Ed.). (1995). Uniwersytet Trzeciego Wieku w Warszawie [University of the Third Age in Warsaw]. Warszawa:

Uniwersytet Trzeciego Wieku przy Centrum Medycznym Kształcenia Podyplomowego.

Thomae, H. (1992). Contributions of Longitudinal Research to a Cognitive Theory of Adjustment to Aging. Personality. (6), 157-175.

Turner, J. S., \& Helms, D. B. (1995). Lifespan Development (5th ed.). Fort Worth: Harcourt Brace College Publishers.

United Nations. (2002). Political Declaration and Madrid Internation Plan of Action and Ageing. Retrieved from www.un.org/en/events/pastevents/pdfs/Madrid_plan.pdf

Vellas, P. (1974). Université du troisième âge [University of the Third Age]. Toulouse: Échanges internationaux et développement.

World Health Organization (WHO). (2015). World Report on Ageing and Health. Geneva. Retrieved from http://apps.who.int/iris/bitstream/10665/186463/1/97892406948 11_eng.pdf

Zdziarski, M. (2014). Codzienne i odświętne narracje w sprawie starości [Daily and festive narrations on old age]. In B. Szatur Jaworska (Ed.), O sposobach mówienia o starości. Debata. Analiza. Przykłady [About ways to talk about old age: Debate, 
analysis, examples] (pp. 81-84). Warszawa: Biuro Rzecznika Praw Obywatelskich.

Ziębińska, B. (2007). Uniwersytety Trzeciego Wieku jako instytucje przeciwdziałające marginalizacji osób starszych [Third Age Universities as institutions to combat marginalization of older people] (Unpublished doctoral dissertation). Katowice:

Uniwersytet Śląski. Wydział Nauk Społecznych. Retrieved from www.sbc.org.pl/dlibra/doccontent?id=7028 

Suggested Citation: Del Gobbo, G., Galeotti, G., \& Esposito, G. (2017).

Intergenerational Education for Social Inclusion and Solidarity: The Case Study of the EU Funded Project "Connecting Generations". In Ł. Tomczyk \& A. Klimczuk (Eds.), Selected Contemporary Challenges of Ageing Policy (149-187). Kraków: Uniwersytet Pedagogiczny w Krakowie. Doi:

$10.24917 / 9788380840911.8$

\title{
GIOVANNA DEL GOBBO ${ }^{1}$
}

\author{
GLENDA GALEOTTI ${ }^{2}$
}

GILDA ESPOSITO ${ }^{3}$

\section{Intergenerational Education for Social Inclusion and Solidarity: The Case Study of the EU Funded Project "Connecting Generations"}

\begin{abstract}
This paper reflects on lessons learned from a validated model of international collaboration based on research and practice. During the European Year for Active Ageing (2012), a partnership of seven organizations from the European Union (EU) plus Turkey implemented the Lifelong Learning Programme partnership "Connecting Generations" which involved universities, non-governmental organizations, third age Universities and municipalities in collaboration with local communities. Reckoning that Europe has dramatically changed in

${ }^{1}$ Giovanna Del Gobbo, University of Firenze, Department of Education and Psychology, Italy, giovanna.delgobbo@unifi.it.

2 Glenda Galeotti, University of Firenze, Department of Education and Psychology, Italy, glenda.galeotti@unifi.it.

${ }^{3}$ Gilda Esposito, University of Firenze, Department of Education and Psychology, Italy, gilda.esposito@unifi.it.
\end{abstract}


its demographic composition and is facing brand new challenges regarding intergenerational and intercultural solidarity, each partner formulated and tested innovative and creative practices that could enhance better collaboration and mutual understanding between youth and senior citizens, toward a more inclusive Europe for all. Several innovative local practices have been experimented, attentively systematized and peer-valuated among the partners. On the basis of a shared theoretical framework coherent with EU and Europe and Training 2020 Strategy, an action-research approach was adopted throughout the project in order to understand common features that have been replicated and scaled up since today.

Key words: Intergenerational Relationships Learning, Intergenerational Solidarity, Lifelong Learning

\section{Introduction}

It is well discussed in literature that at least three demographic challenges could actually detain Europe 2020 strategy (EC, 2010) from seeing realized its goal (Gros, Roth, 2014) to become a smart, inclusive and sustainable continent. These are mass migrations, population ageing and population decline. These challenges represent different sides of the same polygon: while cultural changes, low fertility, and increasing longevity cause populations to rapidly grow older and decline in absolute numbers, the only reducing, and not fully intentional, measure to stop such a phenomenon over the years has been to sustain migration flows, especially of youth, from neighboring or farther away developing countries.

How can European citizens possibly thrive in a Europe that is feared to be the only continent on Earth whose population will shrink by 2050? Can we think of a sustainable society where young and older adults are so far apart and face conflicting challenges to survive?

According to a study carried by Eurostat in 2015 (Kotzeva, 2015) and 2016 on average, each European woman has 1.58 children in the EU, substantially below the 2.1 children needed to sustain the current population level. Due to low death rates and 
high net migration, the overall population in Europe may be increasing, but the median age is crawling slowly upwards: 42 years in 2014 compared to just 29 a decade earlier.

The strains on welfare, pensions, and healthcare systems are easy to imagine but very difficult to prevent or govern, as Europeans live longer than ever before. Young Europeans will have to work harder, even in countries where unemployment rates are fierce and be more efficient and productive in order to pay for the healthcare and pensions of a growing cohort of older Europeans. On the other side, older Europeans may have to put off retirement, working well into their 70 s and preventing younger generations to enter the labor market.

While reckoning the importance of the demographic and economic perspective, as education and training experts and activists how are we going to tackle the education needs of a deeply mutated EU population?

The hypothesis of this paper is that, according to the evergrowing societal demand for social inclusion, intergenerational learning, realized in a non-formal education setting and valuing nonformal settings, can contribute to create fertile grounds for dialogue among young and old people and foster new ways to face common challenges, with the shared objective of the well-being of all.

\section{The "CONGENIAL: Connecting Generations" Project}

Reckoning such challenges, the project "CONGENIAL: Connecting Generations" was formulated and developed. The results that are presented in this paper show us a way to link three key concepts: lifelong learning, social inclusion, and intergenerational solidarity.

"Connecting Generations" activities were realized during two years long European Learning Partnership funded in 2012 under the European Commission Lifelong Learning Programme 2006-2013 (LLP) and specifically within the Grundtvig subprogram dedicated to adult education. LLP no longer exists as we write and has been replaced by Erasmus Plus starting from 2014. The latter was intended to represent a less fragmented approach to education and training, with a higher level of interaction among 
the fields of high, vocational, school, and adult education, compared to the past. It is too early to evaluate if such objective was met in three editions (2014, 2015, and 2016) of Erasmus Plus but CONGENIAL expressed and developed LLP principles, and its results are coherent with the overall vision of lifelong and life wide learning.

LLP was indeed a courageous program in putting education and training on the agenda not only of States and experts but also of civil society activists scattered around Europe and with few opportunities to exchange and learn from each other. LLP contributed to creating and developing common spaces of interaction in learning and training throughout Europe. It offered an opportunity to build Europe from grassroots and not make it descend from above, especially from EU institutions in Brussels, often perceived as far and hostile to citizens. LLP made possible that people from different countries and backgrounds meet and work together in piloting innovative actions for change. In particular, learning partnerships were a very "easy and friendly" to use format of learning through practice that was available also to small organizations: partnerships focused mainly on exchange of practices and experiences through mobility (study visits) and did not request too high projecting competencies from submitters, seldom available, as it would be later the case, and the pitfall, with Erasmus Plus.

LLP was established "[...] to contribute through lifelong learning to the development of the Community as an advanced knowledge society, with sustainable economic development, more and better jobs and greater social cohesion" (http://ec.europa.eu/education/lifelong-learning-programme_it).

LLP meant also to ensure the protection of the environment for future generations. The goal of the program was, in particular, to enhance and sustain cooperation and mobility between education and training so that European member states, and Europe as a whole, become a landmark of world quality.

In other words, the Lifelong Learning Programme was designed by policy makers to enable people, at any stage of their life, to take part in stimulating learning experiences, as well as developing education and training across Europe. Citizens could 
participate in LLP both as students (of formal and non-formal education), members of associations, professional figures in different fields of education but as well as individual citizens, through their LLP National Agencies.

In the Grundtvig sub-program, dedicated to adult education, the following were considered as priorities. Covering teachers, trainers, staff, and adult learners, among others, the program aimed to:

- Increase the number of people in adult education.

- Improve mobility conditions in adult learning.

- Improve the quality and cooperation between adult education organizations.

- Develop innovative educational and management practices.

- Ensure social inclusion through adult education.

- Support innovative information and communications technology (ICT)-based educational content, services, and practices.

That happened even before the "quasi-concept," meaning an ideal scenario that still needs more scientific systematization, of "social innovation," became pervasive in the EU Agenda. ${ }^{4}$ In fact, among the reasons why we propose to reflect on this particular project two years after its completion emerges from our belief that it has represented an incubator of social innovation related to active ageing and therefore still has potential impact to play.

The coming to life of the project "Connecting Generations" was in itself a good practice: partners met in Villasimius, Sardinia, Italy in October 2011 during a three days international contact seminar organized by the Italian National Agency and could start a dialogue on needs and resources each one of them could make available for contributing at the EU level to the overall cause of enhancing intergenerational learning and active ageing, in the

\footnotetext{
${ }^{4}$ According to the EU Directorate for Social Research, social innovation represents an important field of research for social scholars and humanists, necessary for policy analyzes within both the Union and Member States (EC, 2013a).
} 
framework of the incoming European Year for Active Ageing 2012.

Three key factors were agreed by experts in Villasimius and brought to adult education activists' attention: (1) senior citizens should fully participate in community life and be socially and culturally engaged. Adult learning is a key asset in this framework and a precious space of experimentation; (2) they should feel more fulfilled at work, for those who are still working with full or part time responsibilities; and (3) they should be put in proper conditions to be more independent in everyday life, with specific supports regarding a resilience mechanism at the individual, community and service level.

Partners decided that "Connecting Generations" project should focus mainly on the first of the three challenges and identified in non-formal adult education an opportunity to build not only new knowledge but also the social capital of older peoples. Learning should not happen in a private and sectorial matter, though: the real feature of the project to start was the cultivation of relations and networks between different generations and cultures. "Connecting Generations" model was meant to produce a toolkit of educative instruments to ensure opportunities for participation, creative thinking and in general active citizenship for the well-being of all EU citizens, intended as the style of life that enables happiness and the permanency of cultural and environmental diversity and, far from the quest for opulence or dis-human economic growth is based on harmony, equality, equity, and solidarity.

With a duration of 24 months and the participation of 9 organizations from 7 different European countries plus Turkey, namely Greece, Italy, Poland, United Kingdom, Romania, Slovenia, and Hungary. The project began in August 2012, disposed of a budget of about a hundred and eighty thousand Euro and ended in August 2014. The maximum available budget to each partner was 24 thousand Euro making it quite easy to handle even for smaller organizations.

The problem that the project intended to tackle can be described as follows. Different generations, grandparents, parents, and young people or children were at risk of isolation, speaking 
different languages, not understanding each other, and living different lives whatsoever. We were witnessing an inextricable puzzle of diversity and distances that could lead to the invisibility of older peoples. As EU citizens and education and training activists, based on our experience and that of others like us, we needed to take an informed action to avoid inequality of opportunities that hinder the right of each person to exert full citizenship. Our challenges were to co-construct a citizens' knowledge society, with no distinction whats oever based on age or sex or cultural provenience. That should come from a genuine communication among generations based on mutual curiosity and respect, in a living values atmosphere. The overall, long-term, result we were seeking was to contribute to a better quality of life for all generations. The particular tool available was a rich portfolio of adult education initiatives already carried out or ready to be experimented by partners.

The goal of the project was to create in our local communities an enhancing environment conducive to intergenerational communication and mutual understanding that should lead to a better quality of life for all, through non-formal and informal adult education activities carried out by the partner organizations, as well as to produce and transfer knowledge, methods and good practice for senior citizen education and intergenerational learning through mobility and a shared online platform at European level which also includes Turkey.

The specific objectives of the project were:

1. To develop innovative methods to foster communication and create learning opportunities between older and younger generations based on exchanging good practices of the participant organizations.

2. To realize at least 120 mobility between seven European countries and Turkey to learn from each other and develop together good practices in intergenerational pedagogy.

The approach had four main aspects:

- Experimenting innovative, non-conventional forms of communication and learning to enhance mutual understanding and recognition between generations (e.g., 
world cafes, learning circles, e-mentoring, learning through arts especially music and dance, and paideia).

- Offering learning opportunities, based on participation and creativity to be shared and utilized by the old and the young, preserving and sharing cultural memories (e.g., traditional games, folk art, and art crafts) as well as opening to the digital era (social media, ICTs in general).

- Exchange good practices through mobility, a web platform, and international seminars.

- Systematize all the above in a user-friendly e-publication, based on a scientific method.

\section{A Framework for the Project: New Needs and Challenges for Adult Education in Europe}

Once recognized the need to pave new roads of intergenerational learning, there is a growing space for research and experimentation that will have positive feedback also on social inclusion and the valuing of cross-national, and cross-generational dimensions.

According to the World Health Organization (WHO, 2002), active ageing can be defined as the process of optimizing opportunities for health, participation, and security in a framework of quality of life as people age. Older people who retire from work, ill or live with disabilities should not be seen as a burden in ever more consumer society where people are valued only under materialistic terms: on the contrary, they should be recognized as active contributors to their families and communities. They are a key entity in shaping multiple identities, in continuous negotiation with younger generations, and transmit and modify cultural heritage.

Validated policies and practices of active ageing put people in the conditions to realize their potential for physical, social, and mental well-being throughout the life course and to participate in society. The word "active" in fact refers to continuing participation in social, economic, cultural, spiritual, and civic affairs, not just the ability to be physically active or to participate in the labor force. Interdependence, intergenerational solidarity, as 
permanent learning that should be enhanced, not interrupted in the last age of life, are essential tenets of active ageing.

The Member States offers a framework for the implementation of policies in Europe that are functional to a smart, sustainable, and inclusive society (EC, 2010). Out of ten guidelines contained in the integrated document, the first six are devoted to economy, while the last four focus on employment and in particular guideline number 8 refers explicitly to lifelong learning: "Developing a skilled workforce responding to labor market needs, promoting job quality and lifelong learning "and number 9 stresses the importance of improving the systems of education, training, and education:" improving the performance of education and training systems at all levels and increasing time participation in tertiary education" (EC, 2010, pp. 21-22).

It is not, as we know, a new position: Europe for several years has emphasized the need for high-quality education and training to provide high-quality skills responding to the changing requirements of the labor market. In most contexts and through various financing measures Europe strived to demonstrate how a system of adequate and reliable services is crucial. Indeed it is the basis to generate a smart, sustainable, and inclusive Europe. It is not just a matter of educating and training the staff needed for research, development, and innovation, and therefore provide a productive and flexible labor force: it also means working on policies to face the impact of an ageing population in the workforce, decreasing the so-called "transmission of poverty" from one generation to the next. In fact, low-income families tend to invest less in education and training, and without adequate policies, there would be no enhancement of non-formal and informal dimension of learning or other know-how.

\footnotetext{
${ }^{5}$ The main objective of the EU, according to which the Member States must define their national targets, is to reduce the dropout rate of $10 \%$, while increasing the share of the population aged 30-34 having completed tertiary or equivalent education to at least 40\% in 2020 (EC, 2010).
} 
In order to boost growth and jobs, to avoid the mismatch ${ }^{6}$ between training and work, not only education and training systems must offer quality and accompany people to acquire the skills that pave the way for a transition to the labor market, but we also need measures and adequate tools to a more effective and more active management of competences: competencies that we already have - how to recognize and exploit them-or those that are missing - with particular reference to core competencies - and those to be built anew, with particular reference to key competencies, often acquired in the daily life context.

Research results released by the Organization for Economic Co-operation and Development (OECD) show that adult skills in countries that participated in the survey, and their use and impact, are at such a low level that enhancement of social capital is severely limited. Unlike the Programme for International Student Assessment (PISA), which measures cognitive skills of fifteen years old, the results of the Programme for the International Assessment of Adult Competencies (PIAAC) investigate educational policies in the labor market, in welfare systems, in the quality of work in enterprises, in economic policy choices. The research highlighted the ability to manage information and solve problems in technologically rich environments, in particular, capacity to access, evaluate, analyze, communicate and use

\footnotetext{
${ }^{6}$ As we read, for example, in the Programme for Italy "Youth Guarantee" 2014-2020, published in February 2014 (p. 19): "To curb the chances of employment of young Italians is not only the lack of labor demand triggered by the economic crisis, but also a growing gap between the skills required by businesses and those possessed by young people entering the labor market. The so-called "skills mismatch" takes on different forms, determined by several factors (labor force too or too little trained, the mismatch between training and production technologies). A bad 'match' between demand and supply of labor leads to cumulative effects in the long run: working incongruously with their skills." The mismatch between skills acquired and activity also happens among the employed ones: many do not do the jobs for which they are prepared and would be ready to work. In Italy, we face a paradox. There is an unanswered demand for labor and young people looking for a job (European Commission, 2013b).
} 
information through the use of tools and digital applications: all the latter are called Foundation Skills and are considered to represent the cognitive pillar to live and work in the third millennium. An individual with low-level performance in these competencies faces high chances of exclusion from the workplace and in society.

Those studies show the relevance of the problem and support the urgent need for interventions. Surely, attention to learning throughout the course of life requires, beyond the recognition of its intrinsic value, the identification and implementation of new measures and new ways of working in line with a sound framework of theoretical and methodological reference. Its meaning, in fact, goes well beyond contingency planning and identification of intervention measures and financial constraints.

Generally, the correlation with systems of Education and Training was considered functional to production and increase of income, founded precisely on the available capital in terms of knowledge (Becker, 1964). The ratio of investment in education and increased productivity was already highlighted in the 1960s: "More education should contribute to growth in two different ways. First, it should enhance the quality of the workforce [...] this should generate an increase in work productivity [...] Second, a higher cultural level of the population is expected to accelerate the rate of accumulation of the stock of knowledge in society" (Denison, 1966, p. 215). Human capital, according to this approach, differs from other resource stocks only for its structural incorporation in the individual. It is, however, of stock by its nature subject to depreciation and obsolescence and variable returns, in need of a continuous process of updating and adaptation with respect to the advancement of knowledge, with complementary activities and parallel paths of education.

If knowledge guides the production, it is the wheel of development (economic and other) and knowledge is a factor of wealth and well-being, we face a paradox: knowledge itself is reduced to a "good" that is consumed quickly, and as quickly, in fact, it becomes obsolete. At the same time, we start valuing and assessing the "quality" of knowledge in which to invest: many 
kinds of knowledge cannot be recognized in their value, but they can still express a potential to be exploited. In the knowledge and information society, culture and education risk progressively becoming market products, following the rules of any other product. Moreover, knowledge is valuable to the extent that it is able to serve the production process and lead to income: knowledge thus appears as capital to invest not as "human capital," but as functional to productive development. Therefore, the so-called "intangible economy," invests in education, training, vocational training, immigration policies, improving the health of workers and other intangible factors that increase the productivity of labor. It seems to be an imperative to try to capitalize on the human capital of which a certain country can dispose of. The risk is to assess human beings in terms of cost or benefit, damage or benefits, and losses or gains, denying the value of the concept of human capital in its entirety.

If human capital is defined as a multidimensional and unobservable construct created by investments in education, training, health, family and socioeconomic background, such as to cause an effect on productivity, observable from labor income, the evaluation of the system of knowledge of the subject has to be measured by a multi-parameter setting within which correlation with the production performance nevertheless remains central.

However, the concept of human capital in recent years drew attention to the economy of training as part of a debate increasingly connected to the development of society: it is now increasingly related to the concepts of sustainable and endogenous development and social cohesion. The constructs "human capital" and "human development" in recent years seem to share similar paths of revision and extension of their meanings. The Human Development Index is a key step in this path with the fundamental importance given to education and literacy processes, but two other documents are certainly significant.

In 2009, the so-called Stiglitz Commission Report was published under the title of Commission on the Measurement of Economic Performance and Social Progress. In the Report, edited by Joseph Stiglitz, Amartya Sen, and Jean-Paul Fitoussi (2009), they highlight the indispensable need to identify indicators to 
measure the quality of life, sustainable development, and the relationship with the environment. The report, rather than concentrating on production, focuses on indicators to measure the well-being "from the people's side" by identifying seven dimensions that are fundamental: the psychophysical state, knowledge, and ability to understand the world in which you live, the environment, interpersonal relationships and participation in society. To these we add two cross-cutting dimensions: equity, regarded as the balance between the intra-generational relationships and sustainability, understood in terms of the balance between the generations. We refer to a fair and sustainable wellbeing for which not only quantitative but also qualitative variables of the human condition are crucial.

The intergenerational perspective becomes, therefore, not only a necessity for social inclusion but also a potential indicator of well-being and sustainable development. Moreover, the knowledge that seems to be characteristic of a past generation and therefore considered obsolete (both regarding production and social relations) may be regarded as an expression of human potential.

Speaking of intergenerational balance obviously, entangles economic factors related to a relationship between "productive generations" at work and "generations" who are enjoying retirement. The boundaries between these phases, with the transformation of the labor market that we are currently experiencing, however, are very unstable and fluid. The distinction is no longer clear, if not, in some cases, paradoxically reversed. We encounter in fact more and more situations in which generations of aged parents no longer in the labor market represent an actual economic support for the young generation in an employment crisis. In addition, there are also demographic considerations with respect to an ageing population.

The phrase "the future is in the hands of young people" would seem no longer true if the majority of the population, at least in the Western world, is not so young anymore: without sharing of knowledge necessary to build a sustainable future, without a new "platform" shared between generations, there is nowadays no more future whatsoever. 
All this requires a reconsideration of the meaning of intergenerational dialogue and effectively valuing the necessary collaboration and intergenerational continuity. It is increasingly evident that traditional and neat classification of the phases of life, social roles and production is losing ground. In addition, and perhaps more importantly, this is now happening in daily life: it is a phenomenon that needs to be understood and managed, that also requires the construction of new knowledge to give meaning and depth to a generational continuity that takes on new value in terms of social ties and in terms of intergenerational solidarity. The solution seems to be horizontal collaboration and solidarity becomes a mutual need.

In a lifelong learning perspective, a new need for competencies to manage the continuity and attribute meanings emerges. Indeed, it appears to be essential to reflect on generational transfer of meanings not only in diachronic but synchronic manners. The need for a dialogical perspective in which knowledge can be shared and placed in continuity with a future under construction appears evident.

When we think of intergenerational dialogue, we often recall the term "transmission." The etymology of the term, from the Latin transmittere, in fact, refers to the sense of the "switch" from one person to another, from one place to another, from one time to another, from one generation to another. It suggests the idea of "pass the baton," and it brings to mind the metaphor of relay: a role game in which one enters consciously in the race to bring forward the result reached by the other and no one runs much and only for himself, but toward a "team objective." No one can stop the run. It is not a possibility. Who passes, does not "drop" the baton, but he "deliveries" to another person certain that he who receives shares the same rules of the game, recognizes the value of the sign, as well as the duty to continue on.

So, in the action of transmitting, both the one who passes and the recipient have an active role and share meanings. If we return to the metaphor of passing the baton in a social context, however, we can grasp the need to consider also the need to negotiate and re-interpret meanings in the transition, which necessarily become related to the perspective of which they are 
interpreted. Moreover, in light of the above considerations, we understand the "race" can even involve those who had already abandoned but are needed the field again.

From the educational point of view, the node appears to be attributable to the "how to" share "meanings," often between past and present, and between the present and the past. Surely educational practices using memories can be reviewed and enhanced. Memory should definitely be preserved, but at the same time, it can be considered as a useful seed to produce future. This is to define the meaning of a "memory" that does not crystallize the memory itself but gives shape to negotiated meanings, in the present, for the future.

"Memory" is indeed a term that we meet more and more often, sometimes abused and almost exploited in a society that often makes fashion of it: the fashion of the past is often a clumsy expression of a widespread fear of loss of roots, it seems an anchor to answer an apparent collective amnesia that disorients us on who we really are, but that is likely to stiffen the idea of identity, making it static, shut, closed in on itself. Zygmunt Bauman (2010) talks about "roots" and "anchors" in identity and socialization processes, "while the roots torn from the ground where they grew will probably will dry up and die, anchors are pulled out only to be thrown somewhere else, and can be thrown with the same ease in many different ports, at very long distances" (Bauman, 2010, p.19). According to Bauman's metaphor while roots may not grow another type of plant, anchors facilitate the temporary docking of a vessel to a peer, and for this reason, do not affect the quality or capacity of the ship. Memory, as a possible object of an intergenerational dialogue, should probably be more about knowing we have an anchor rather than finding our own roots. Especially if we should take into account more and more of a "web of continuity and discontinuity in history and a growing number of contemporary identities" (Bauman, 2010, p. 20) and parallel that "almost no affiliation can comprise the "whole self," because every person is involved, not only in the course of their lives but at any time of life, in multiple memberships" (Bauman, 2010, p. 20). 
There will probably be less and less social knowledge connotations dependent on generations. We will have to reconsider and re-negotiate knowledge that, by osmosis, becomes part of the training of each subject and creates continuity: informal knowledge, stemming from everyday life, can definitely be a basis for dialogue, a starting point. Such knowledge can, better than others, be immediately perceived as significant as with it is developed and socially built to respond to the problems of everyday life. This knowledge threatens to appear less meaningful, less decisive, more interpretable, and therefore not communicable and negotiable in the present so different from the past.

The prevalence of the formal dimension of learning, with its equipment and technological support, has over time led to the lack of consideration, if not to the devaluation, of informal knowledge that the subject constructs and processes within the context of his own life. Through memory we preserve the memory of our training process, usually unconsciously: knowledge linked to the interpretation and transformation of the environment, to the experience of reality through the individual experience, collectively shared. Duccio Demetrio (2002) defines memory as a "network of narratives that we defend and that we have defended, showing us that we had a story, we had a plot." Nevertheless, this story and this plot necessarily refer to the sense of identity and belonging that develops in sharing knowledge and expertise, not only to recognize and be recognized, but also to build new knowledge.

The enhancement of this heritage, therefore, needs to be based on the involvement of the generations and it cannot be delegated or assigned only to the school system. Non-formal education of adults and community education can instead play an essential role that must be recognized and supported.

\section{The Main Results of the CONGENIAL action-research}

The CONGENIAL project was developed through local initiatives with an explicit educational objective: aimed at promoting lifelong learning for young and older people in shared spaces, regardless of socioeconomic or cultural background. It also worked for the social inclusion of older people through recognition of their 
knowledge and produced a renewed effort to strengthen an intergenerational link with young people. This objective was shared at the international partnership level, where analysis and reflection on the ongoing experiences and practices were pillars for cooperation between different organizations (Lave, Wenger, 1991).

Educational activities of CONGENIAL were the object of a qualitative research made by the partner organizations, ${ }^{7}$ to make explicit the complexity of the contexts in which they operated, to trace the peculiarities of educational actions and define their characters of methodological innovation, in terms of a transformative educational action (Mezirow, Taylor, 2009).

The key theoretical assumption of this qualitative study is that the fundamental way of knowledge building is essentially linked to the direct experience of the subjects, and most of the learning comes from practice (Dewey, 1933). Human beings face similar situations and try to select the solutions and procedures that proved more effective in the past and adapt them to the new task to perform.

One must also consider that often learning is distinguished by its experimental character and a significant part of tacit knowledge, and therefore, greater awareness of action can be produced by introducing reflective and comparative moments on experiences. Reflexivity (Schon, 1983; Lipman, 1991) is based on the repertoire of cases and experiences of the past that allow to act on assumptions and to move into problematic situations, identifying possible solutions while comparison relates to the production of knowledge through the detection of similarities and differences between those situations that are under the lens.

Both of these processes allow reaching a higher level of knowledge (Mortari, 2009; Fabbri, Striano, Malacarne, 2008), thanks to:

\footnotetext{
${ }^{7}$ This project action has been implemented by Edaforum in collaboration with the Department of Science of Education and Psychology, University of Florence.
} 
- The comparison between different points of view that allows the transition from the subjective dimension to intersubjective validation of acquired knowledge.

- The overcoming of the false idea that is possible to formulate general laws and theories that can be applied in every context.

- The recognition that transfer of knowledge is not always possible because what we know is the result of a unique understanding of a specific situation.

Despite this, a certain degree of replicability and scalability is possible in understanding actions undertaken in different contexts and their fundamental characteristics that can make interventions recognizable outside and comparable with similar experiences. So, the analysis of practices that a specific professional community realizes, as in the case of Connecting Generation, intends to find their own features and identify common elements that can revise the theoretical and/or methodological models of reference: from a significant number of experiences that have been valued a sort of meta-model positively can emerge, as a basis for the definition of "good practices."

The research methodology included direct involvement of all operators, who provided data and evidence for their validation. During international meetings, the various educational experiences have been the subject of a common analysis and reflection. Operators also created thematic focus groups, on memory, participation, arts, traditional knowledge just to mention a few, and collected and analyzed research data.

The research began with collection and analysis of existing educational experiences that promote intergenerational dialogue, with the aim of identifying some useful criteria to assess and compare the interventions of adult education carried out by the project partners.

Thanks to this set of criteria identified in similar activities and interventions, research has developed a comparative analysis of the educational activities carried out by educators, teachers, or operators in the local communities where the organizations 
operate. $^{8}$ They share the same initial problem-the dialogue between generations - within the same area of intervention - adult education - to reach a common objective, as the development of a shared methodology.

The following phase of the investigation was data collection on educational activities and practices carried out by partners' organizations (the analysis also took place through focus groups with local operators) and on joint activities of the international partnership (analysis of the records and reports of international meetings), then moved on to decoding of the above according to the method of "content analysis" (Semeraro, 2011).

This involved the identification of analytical units, and then the decoding of the aggregations of data according to two criteria: the first described the activities in specific operational contexts; the second one detected the relationship between the key elements that characterize the activity under investigation. The results of this process have been assessed and validated, together with those

${ }^{8}$ Educators, teachers, and operators involved in educational activities have carried out the compilation of the form through a group effort that involves three basic steps: the description of the activity, the analysis of some of its features, the interpretation/reflection on the elements that define the activity itself. The activity description is primarily to provide some qualitative data to narrow the experience (e.g., title, objectives, target, and duration); the analysis phase focuses on three main elements: the learning needs of participants, networks enabled by the implementation of activities, the educational methodology adopted. In particular, the training needs are identified with the analysis of the context at two levels: the demographic changes in European society, the youth issue and other social challenges that Europe is facing; the specificity that these changes acquire in different countries involved in the project. In the third and last step of reflection on educational practices implemented, operators have reinterpreted activities from some key concepts to highlight their intergenerational and innovation elements, to check the consistency of the results achieved with objectives proposed, to define the learning of the operators in the specific educational sector. The results of data analysis have been validated in a participatory way through local and international focus groups that have involved representatives and members of all the partner organizations. 
of the project, with the focus groups with all international partners in the last project meeting in Poland.

In this action-research, the construct of "educational practice" is central, coherently with complex actions that want to achieve an educational purpose, or, in other words, an activity consists of actions and choices intentionally made to achieve one or more learning objectives. The key feature of educational practice, compared to other types of practices, is the special relationship between the educator, or educators, and learner, or learners.

To read and deconstruct a practice, it is important to make explicit its constituent elements, to bring out less visible dynamics, to be able to report the empirical evidence, in short, to provide feedback from data collected in the field in order to guide the process of understanding and interpretation (Laneve 2005; Roig Vila, Laneve, 2011).

According to an integrated logic, the analysis of the CONGENIAL educational practices was carried out to know complex dynamics of education: how educators act in certain contexts, and to achieve certain goals. Central was also the meanings attributed to the actions realized, hopes and expectations that animated them, all tacit knowledge involved.

Therefore, quality research on educational practices for intergenerational dialogue has allowed us to identify and circulate results, innovative products, and processes, and especially good practices successfully tested that can be a model to follow, which integrate professional skills and knowledge with the best available empirical evidence to support the learning processes. Given the characteristics of CONGENIAL partner organizations, the contexts where they operate, and the heterogeneity of the activities carried out, the possibility of generalization and transfer will not involve "whole practices," but rather some of their segments, which however may stimulate discussion with other stakeholders who face similar challenges.

This can be seen as the main contribution that "Connecting Generations" has given to the development of the European system of lifelong learning, in terms of strengthening the knowledge and skills of the professionals involved in adult 
education (Demetrio, 2002) and in particular in the framework of active ageing and intergenerational solidarity (Baschiera, Deluigi, Lupi, 2014).

The attention paid to the participatory processes in education activities, in the broader work with the local communities for the construction of networks, including the activities of the international partnership, has allowed us to spread the knowledge gained at all levels of the system implemented by "Connecting Generations": dialogue, discussion and the enhancement of experience-life, business, personal and collective, and more-have strengthened the link between specific educational action and their social impact in local communities, as well as a better understanding of new and possible forms of cooperation and solidarity between generations (Hansen, Molpeceres, Rothuizen, 2012).

We, therefore, present the main results of the analysis, comparison, and evaluation of intergenerational education practices, realized by each organization involved and shared within the international partnership. It is possible to have a shared description of intergenerational education, declined in its basic elements and that highlights some methodological and operational criteria.

The first element emerging from the participatory analysis of the realized practices regards the types of needs to which intergenerational education responds. Mainly, they are social, educational and community needs. In particular, with the first group, we refer to phenomena of social and generational isolation that affect young and old, especially dropouts, unemployed, socially excluded, and computer illiterate. Hence the need to strengthen knowledge and skills of learners, through lifelong learning opportunities that foster dialogue, exchange, and daily interaction between people of different ages, sexes, and ethnic origins.

From the point of view of educational needs, this type of intervention can be used to introduce elements of nonformal education and divergent thinking in formal education, especially for youth with learning and adaptation difficulties to the school system. At the same time, this education meets specific training 
needs such as knowledge of a foreign language or ICT, particularly for the older generation, or for the acquisition of soft skills such as the ability to, for example, cooperate and collaborate and problem-solving. On the other hand, a second need is a knowledge need of educators that work in the formal, non-formal and informal sectors on methods and techniques of intergenerational education, including those on innovative technologies. The third type of need, those of communities, refers to the loss of cultural identity, such as local knowledge and expertise, which puts at risk the indispensable resources for the endogenous development of the territories, and to the need of mutual understanding, active citizenship, and solidarity to build fairer and more cohesive societies.

Directly connected with these types of needs, the intergenerational educational objectives pursued by CONGENIAL activities highlight their strong social and cultural mark. A vision of learning as a means of social and community cohesion emerges, rather than being geared exclusively to individual development. Supporting dialogue and mutual understanding between generations, this education contributes to fighting social, cultural and technological isolation and marginalization, and at the same time to enhance the traditional knowledge of older generations in training of young people, recalling and sharing memories, values, cultural and local heritage in order to improve the quality of life in the local community.

On the side of the research, one of the objectives of intergenerational education is to experience innovative practices, educational methods, and activities of intergenerational learning in formal, non-formal and informal education.

Moving on from the descriptive level of intergenerational education activities to more interpretative one about data collected during the research, we can develop three reflection axes.

The first one focuses on the main methodological and operational elements that create solidarity between generations. Beyond the different educational methods used to build bridges between generations, the analysis shows that some criteria used to define a methodological framework can extend to all activities carried out and bring them back to a common framework. 
A key element is the required reading and interpretation of social and educational needs of participants, but also their expectations. The purpose of this initial activity is to create favorable conditions to pursue effective actions, to build cohesive work groups, to propose topics that affect all participants, capturing their attention and their motivation.

Another element concerns the reciprocity of learning and the enhancement of generational knowledge. The older adults are the custodians of traditional knowledge and trades that are disappearing and losing their value, in particular among the younger generation. Their collaboration in educational activities aimed at youth can spread this knowledge and traditions, avoiding its loss. Likewise, the young (the so-called Millennials) are able to offer in exchange their knowledge on non-traditional communication means linked to the digital world. This aspect leads to another element that characterizes intergenerational learning, as it was interpreted by the CONGENIAL: it is the importance of "working together," as a formative moment based on practical testing of knowledge and on individual learning strongly linked to experiences of intergenerational dialogue.

The second axis concerns the most innovative elements of intergenerational education and detected by the analysis of experiences carried out, that is explained below:

- The dialogue between tradition and innovation using the knowledge and skills of old and young people. If young people were able to appreciate the value of knowledge and stories of old adults, this latter themselves had come to realize how important they are, even in the digital age, the maintenance of traditions and building bridges to transmit knowledge, memories, and experiences that would otherwise be lost.

- The contribution of informal knowledge to formal education. Intergenerational education can make study experiences more real, fun and exciting for those students who have more difficulties in adapting to the system and learning at school, because it responds to basic needs, with a simple and understandable language, it puts everyone in a position of 
ease and avoids the hierarchy among "good" and "bad" students.

- The promotion of not only intergenerational learning, but also intercultural openness. Contemporary society does not always allow young people to have easy access to their grandparents or older people in general, and the stories of the past that they carry. This is particularly the case for young people who are in a foreign country and have lost contact with older people who remained at home, as well as having too superficial relationships with their parents, as they often work all day.

- Changing people and context relationships through education has effects on the community well-being and the quality of life. To allow everyone to voice their opinions, thoughts, and ideas enhance the participation of cross-cutting stakeholders of the local community (children, parents, families, the older adult, and community leaders) in decisions and projects that relate to the community itself.

- The investment in developing and strengthening skills for active democratic participation. In addition to the rediscovery of the values and local history, this educational work aims to improve "public agora," thanks to the use of methods that favor the establishment of non-hierarchical and horizontal relationships among participants.

These elements decline intergenerational education according to criteria that guide the actions of education and training, in addition to those that characterize the role of the trainer in this type of activity. "CONGENIAL" Intergenerational Trainer facilitate the intergenerational exchange process, which concerns peer-to-peer educational where participants learn knowledge and/or expertise held by others, creating a good reciprocity movement between the parties involved. He or she is competent enough to conduct sincere and deep discussions with the group of participants, so that they can experience active and mutual listening, for the inclusion of different points of view and identification of shared solutions.

Such intergenerational trainer also aims to achieve the deconstruction of stereotypes and prejudices that separate 
generations in order to increase mutual respect and recognition. It is in this virtuous and fruitful exchange that "Connecting Generations" became more successful: it fostered self-esteem of young and older participants, as the protagonists of the activities, but also built on the experience and competences of their training and professional educators who have participated in international study visits carried out by their organizations.

In conclusion, intergenerational education experienced within CONGENIAL revolves around two key concepts: the first is that caring for others is an educational key, which is the basis of human experience and allows the establishment of adult identity (Galeotti, 2015). Caring in education involves shared objectives from which to think about social and individual bonds. The other key concept is reciprocity that characterizes intergenerational learning, which is a fundamental process of alliance, networking, meeting, and exchange of knowledge among citizens of different ages. In fact, they may experience inclusive paths through the construction of educational relationships that animate the participation and cooperation of the various segments of the society.

The Table 1 shows how research results are linked with the CONGENIAL project objectives and LLP topics.

\section{Table 1 Relations Between the CONGENIAL Project Objectives and LLP Topics}

\begin{tabular}{|c|c|c|}
\hline $\begin{array}{l}\text { LLL Program and } \\
\text { Grundtvig Action topics }\end{array}$ & $\begin{array}{l}\text { CONGENIAL } \\
\text { project objectives }\end{array}$ & $\begin{array}{l}\text { CONGENIAL } \\
\text { results }\end{array}$ \\
\hline $\begin{array}{l}\text { Education and training of } \\
\text { experts and civil society } \\
\text { activists } \\
\text { Develop innovative } \\
\text { educational and management } \\
\text { practices. }\end{array}$ & $\begin{array}{l}\text { a) Experimenting } \\
\text { innovative, non- } \\
\text { conventional forms } \\
\text { of communication } \\
\text { and learning to } \\
\text { enhance mutual } \\
\text { understanding and } \\
\text { recognition between } \\
\text { generations (e.g., } \\
\text { world cafes, paideia, } \\
\text { learning circles, e- } \\
\text { mentoring, learning } \\
\text { through arts }\end{array}$ & $\begin{array}{l}\text { CONGENIAL } \\
\text { Intergenerational } \\
\text { Trainer facilitates an } \\
\text { intergenerational } \\
\text { exchange process, } \\
\text { which fostered } \\
\text { acquisition by some } \\
\text { participants of } \\
\text { knowledge and } \\
\text { expertise held by others, } \\
\text { creating a good } \\
\text { reciprocity movement } \\
\text { between the parties }\end{array}$ \\
\hline
\end{tabular}




\begin{tabular}{|c|c|c|}
\hline & $\begin{array}{l}\text { especially music and } \\
\text { dance); }\end{array}$ & $\begin{array}{l}\text { involved. } \\
\text { CONGENIAL } \\
\text { Intergenerational } \\
\text { Trainer is competent to } \\
\text { conduct sincere and } \\
\text { deep discussions with } \\
\text { the group of } \\
\text { participants, so that they } \\
\text { can experience active } \\
\text { and mutual listening, for } \\
\text { the inclusion of } \\
\text { different points of view } \\
\text { and identification of } \\
\text { shared solutions. }\end{array}$ \\
\hline $\begin{array}{l}\text { Development of the } \\
\text { Community as an advanced } \\
\text { knowledge society, with } \\
\text { sustainable economic } \\
\text { development, more and better } \\
\text { jobs and greater social } \\
\text { cohesion through lifelong } \\
\text { learning. } \\
\text { - Ensure social inclusion } \\
\text { through adult } \\
\text { education. } \\
\text { Increase the number of } \\
\text { people in adult } \\
\text { education. } \\
\text { Ensure social inclusion } \\
\text { through adult } \\
\text { education. }\end{array}$ & $\begin{array}{l}\text { b) Offering learning } \\
\text { opportunities, based } \\
\text { on participation and } \\
\text { creativity to be } \\
\text { shared and utilized } \\
\text { by the older and the } \\
\text { younger, preserving } \\
\text { and sharing cultural } \\
\text { memories as well as } \\
\text { opening to ICTs. }\end{array}$ & $\begin{array}{l}\text { Changing people and } \\
\text { local context through } \\
\text { education impacts on } \\
\text { community well-being } \\
\text { and the quality of life. } \\
\text { Create or sustain } \\
\text { welcoming spaces for } \\
\text { dialogue between } \\
\text { tradition and innovation. } \\
\text { The focus shifts from } \\
\text { only intergenerational } \\
\text { learning, to also } \\
\text { intercultural openness. }\end{array}$ \\
\hline $\begin{array}{l}\text { To promote interaction within } \\
\text { the Community, cooperation, } \\
\text { and mobility between } \\
\text { education and training. } \\
\text { - Improve mobility } \\
\text { conditions in adult } \\
\text { learning. } \\
\text { - Improve the quality and } \\
\text { cooperation between } \\
\text { adult education } \\
\text { organizations. } \\
\text { Support innovative } \\
\text { information and } \\
\text { communications } \\
\text { technology (ICT)-based }\end{array}$ & $\begin{array}{l}\text { c) Exchange good } \\
\text { practices, through } \\
\text { mobility, a web } \\
\text { platform, and } \\
\text { international } \\
\text { seminars. }\end{array}$ & $\begin{array}{l}\text { Developing and } \\
\text { strengthening skills and } \\
\text { attitudes for active } \\
\text { democratic participation } \\
\text { and communication at } \\
\text { different level of local } \\
\text { society (e.g., schools, } \\
\text { Third Age centers, } \\
\text { associations) } \\
\text { Testing the contribution } \\
\text { of informal knowledge } \\
\text { and ICT to } \\
\text { transformative } \\
\text { Education and Training. }\end{array}$ \\
\hline
\end{tabular}


educational content, services, and practices.

Source: Own elaboration.

\section{Drawing Lessons Learned: Towards a Common Lexicon}

As a conclusion, we report a product as stemming from a collective and extended dialogue among all nine partners of "Connecting Generations" Learning Partnership which developed throughout the project implementation, from the kick-off meeting held in Budapest in November 2012, to the final meeting at the University of Third Age in Bialystok at the end of May 2014.

Since the beginning of the project, as mentioned before, in fact, a reflective approach to learning and therefore to project implementation was put in place, which is not always so common in Grundtvig Learning Partnerships where attention is more on international mobility rather than on producing intellectual output. We intended as "reflective practice" what Donald Schon (1983) introduced at the beginning of the $1980 \mathrm{~s}$ as "the capacity to reflect on action so as to engage in the process of continuous learning."

Traditionally, with few exceptions, learning partnerships during the Lifelong Learning Programme 2006-2013 focused more on the exchange of experiences and building of human capital and social relations, during international mobility, rather than to the experimentation and systematization of the transformative dimension of learning or the production of outputs. The later were tackled by multilateral projects, directly financed by the Executive Agency Education, Audio-visual and Culture (EACEA) and comprising of more sophisticated partnership, often including universities and research centers, and disposing of more significant funding.

In fact, the purpose of collecting lessons learned is to bring together all, or the majority of, insights gained during implementation that can be usefully applied to future projects. Lessons learned can make a great difference for future projects and help practitioners to make them succeed as well as strengthen their competencies. However logical that might sound, it is not always the case in projects: first, lessons learned must be audited 
and documented correctly, without fear of recording also the weakest parts of the project life. Learning comes from failures as well as success, even more from the first than the second. The key verb and action are, for sure, "to reflect" on them. Often, we do not allow ourselves to experience deep reflection as much as it would be necessary, because we are too busy getting to the next task, or completing a report in time for the next deadline.

In finding our common lessons learned we chose the method of "generative word," borrowed from the Freirean approach (Freire, 1970) to adult literacy education, which bases the content of language lessons on learners' cultural and personal experiences. Instead of using generative words to learn how to read and write, as in the original Freirean mission, we used them to deconstruct and reconstruct key concepts that have been strategic in our work, trying to understand them from multiple cultural perspectives. Paraphrasing the "learner centered approach" we tried to mainstream a "practitioner peer-evaluation approach."

The objectives of the common exercise were the following:

- Identify keywords that had characterized our project, be they specific per country or in common, i.e., with an EU dimension.

- Draw lessons learned in terms of strengths and weaknesses of the selected approaches.

- Deepen our mutual understanding of key words and concepts, which had emerged from our work.

As an introduction, we went through the very story of the project implementation, in order to co-construct together a common "lived experience." We identified in circle common keywords of the project. These are action research; active listening and empathy; ageing community and collective dimension; creativity; crisis; the EU dimension; innovation; local and global; network; participation; sharing; and solidarity. Table 2 shows the shared definitions in alphabetic order. It was not an exercise to develop a glossary, but it represents more of a shared vision of key points. 


\section{Table 2 Shared Definitions}

\begin{tabular}{|c|c|}
\hline $\begin{array}{l}\text { Action } \\
\text { research }\end{array}$ & $\begin{array}{l}\text { There is a growing need for research in Europe, in } \\
\text { order to understand ongoing changes and be better } \\
\text { prepared to face them, as citizens as well as } \\
\text { practitioners. Unfortunately, research is too often realm } \\
\text { for "experts" that produce long and difficult to } \\
\text { comprehend reports that end up in some drawers. } \\
\text { Action research is an approach to co-construction of } \\
\text { knowledge that is people-centered. Action research } \\
\text { must be qualitative and quantitative and put citizens in } \\
\text { the condition to understand what is happening in EU } \\
\text { societies at large, and in their own territories. Action } \\
\text { research works through dialogue between disciplines } \\
\text { and privileged witnesses that are the real protagonist of } \\
\text { change. }\end{array}$ \\
\hline $\begin{array}{l}\text { Active } \\
\text { listening and } \\
\text { empathy }\end{array}$ & $\begin{array}{l}\text { No good communication can happen without listening } \\
\text { and in the absence of empathy. In the era of social } \\
\text { media and "social shouting," listening is a } \\
\text { revolutionary tool for intergenerational and } \\
\text { intercultural understanding. During the project } \\
\text { activities, children, youth, and the older adults have } \\
\text { been motivated to listen to each other, without } \\
\text { prejudice and pre-concepts. Listening carefully opens } \\
\text { windows and doors }\end{array}$ \\
\hline Ageing & $\begin{array}{l}\text { The demographic phenomenon of ageing Europe is a } \\
\text { fact, demonstrated by hard data and evidence. We can } \\
\text { see ageing population from two different perspectives. } \\
\text { On one side, we see individual older adults that are } \\
\text { every day lonelier and disconnected from the } \\
\text { community and in need of societal help and specific } \\
\text { welfare policies. However, there is also an issue of } \\
\text { empowerment at stake. In countries such as Italy, } \\
\text { political and economic power is held by the older } \\
\text { generation which is not helping, generally speaking, } \\
\text { the youth to find their place in society. Young people, } \\
\text { as demonstrated in some interviews conducted in La } \\
\text { Spezia, one of the Italian cities involved in the project, } \\
\text { do not see a bright future in terms of social mobility, } \\
\text { while older adults do not feel respected by the youth. } \\
\text { This is connected with a lack of mutual knowledge and } \\
\text { recognition, as a result of absent generative }\end{array}$ \\
\hline
\end{tabular}




\begin{tabular}{|c|c|}
\hline & communication. \\
\hline $\begin{array}{l}\text { Community } \\
\text { and } \\
\text { collective } \\
\text { dimension }\end{array}$ & $\begin{array}{l}\text { If we could go back to a time machine to fifty years } \\
\text { ago, we would find a very different Europe. Although } \\
\text { still scattered by the consequences of Second World } \\
\text { War and the Cold War, we would find more cohesive } \\
\text { communities, built on non-monetary bounds and fed by } \\
\text { a sense of mutual trust and solidarity. The rise of } \\
\text { consumerism has coincided with mounting } \\
\text { individualism, which is at the opposite end of the } \\
\text { continuum with the community and collective } \\
\text { resilience strategies. Older people and youth are } \\
\text { lonelier than in the past: youth have found an } \\
\text { alternative, virtual, a community on social networks } \\
\text { while older population can scarcely count on their } \\
\text { families and peers. The ongoing crisis put belonging to } \\
\text { and striving for a community under the light again: a } \\
\text { community of people who can identify alternative } \\
\text { solutions to economic scarcity in, for instance, a social } \\
\text { and solidarity economic based on people's resilience } \\
\text { and respect for Mother Earth. }\end{array}$ \\
\hline Creativity & $\begin{array}{l}\text { Traditional education and training have amply } \\
\text { demonstrated its limits both in formal and non-formal } \\
\text { education. Especially schools and universities are } \\
\text { tailored to the needs of an Industrial Society that no } \\
\text { longer exists as in the past century. Creativity and } \\
\text { creative people are able to create values and are the } \\
\text { real pioneer of social and educational innovation. } \\
\text { Creativity was a key word in "Connecting } \\
\text { Generations," and it represented a successful solution: } \\
\text { where traditional means failed, teachers, educators, } \\
\text { facilitators, and volunteers looked for alternative ways } \\
\text { that put values on dialogue and collective action. }\end{array}$ \\
\hline Crisis & $\begin{array}{l}\text { If we could "google" everyday chat in markets, } \\
\text { workplaces, or bars since 2008, it would be very likely } \\
\text { that the word "crisis" would be among the ten most } \\
\text { pronounced words. As French philosopher Serres } \\
\text { (Serres, 2003) clearly elaborated the ongoing social, } \\
\text { economic, and ecological crisis can be compared to the } \\
\text { crisis of a seriously ill person: it is a transitory phase } \\
\text { which cannot but transform itself and the bearer: either } \\
\text { he dies or overcome the illness and "change." That is a }\end{array}$ \\
\hline
\end{tabular}




\begin{tabular}{|c|c|}
\hline & $\begin{array}{l}\text { similar situation for the world society: we are deeply } \\
\text { sick (do we need more evidence than climate change, } \\
\text { ISIS and the bleeding of African youth toward the } \\
\text { North, just to mention a few?) and we should either } \\
\text { extinguish or change. In Chinese ideograms crisis, as } \\
\text { often recalled, is the results of two items: risks and } \\
\text { opportunities. We should take our risks and welcome } \\
\text { crisis as an opportunity for transformation. }\end{array}$ \\
\hline $\begin{array}{l}\text { The EU } \\
\text { dimension }\end{array}$ & $\begin{array}{l}\text { EU should be built from grassroots, via the experience } \\
\text { of its citizens who envision a common project. It } \\
\text { should not only be a paragraph in EU project formats } \\
\text { but a vision of a multicultural, multi-age, and diverse } \\
\text { society that values differences, instead of shunning } \\
\text { them. One of the most felt impacts of "Connecting } \\
\text { Generations" was, in fact, strengthening EU } \\
\text { citizenship: through mobility, we could appreciate and } \\
\text { experience the hospitality and genuine, positive, } \\
\text { curiosity for cultures diverse from ours. The project } \\
\text { also consolidated some EU promoted key } \\
\text { competencies: speaking foreign languages, cultural } \\
\text { awareness, social competencies, and entrepreneurship. }\end{array}$ \\
\hline Innovation & $\begin{array}{l}\text { It means not only doing or creating something new but } \\
\text { also performing new tasks with new attitudes and } \\
\text { applying new competencies. We focus on social and } \\
\text { educational innovation in particular. According to the } \\
\text { EU, social innovations are innovations that are social } \\
\text { in both their ends and their means - new ideas } \\
\text { (products, services, and models) that simultaneously } \\
\text { meet social needs (more effectively than alternatives) } \\
\text { and create new social relationships or collaborations. } \\
\text { They are innovations that are not only good for society } \\
\text { but also enhance society's capacity to act. Social } \\
\text { innovations take place across boundaries between the } \\
\text { public sector, the private sector, the voluntary sector, } \\
\text { and the household. According to Murray (Murray, } \\
\text { Caulier-Grice, Mulgan, 2010) in the "Open Book for } \\
\text { Social Innovation" in } 2010 \text { innovations are new ideas } \\
\text { (products, services, and models) that simultaneously } \\
\text { meet social needs and create new relationships or } \\
\text { collaborations. In other words, they are innovations } \\
\text { that are both good for society and enhance society's }\end{array}$ \\
\hline
\end{tabular}




\begin{tabular}{|c|c|}
\hline & $\begin{array}{l}\text { capacity to act. This has done quite a lot during the } \\
\text { project: new methods have been experimented with } \\
\text { and demonstrated the urgent need to respond to new } \\
\text { challenges, with new tools. }\end{array}$ \\
\hline $\begin{array}{l}\text { Local and } \\
\text { global }\end{array}$ & $\begin{array}{l}\text { In the era of irreversible globalization there is } \\
\text { mounting need, and desire, to affirm the local } \\
\text { dimension of change. While we seem to have very few } \\
\text { instruments to affect global dynamics, we, as citizens, } \\
\text { feel much more empowered in taking decisions and } \\
\text { participating in innovative projects, at the local level. } \\
\text { Without forgetting the international EU dimension, a } \\
\text { project such as "Connecting Generations" value the } \\
\text { local experience and bring that to the common learning } \\
\text { space. So, that we could rephrase famous lemma "think } \\
\text { globally, act locally" and the contrary is also true } \\
\text { "think locally and act globally." They both show the } \\
\text { validity of crossing perspectives in projecting: } \\
\text { fostering intergenerational learning is an EU challenge } \\
\text { that develops in different national contexts. Comparing } \\
\text { situations and practices made the project concretely } \\
\text { "glocal." In particular, older people can be considered } \\
\text { as guardians of traditions, mainly local, while youth } \\
\text { tend to be virtually connected to the world dimension } \\
\text { of education and communication. }\end{array}$ \\
\hline Network & $\begin{array}{l}\text { There is an immense amount of literature about } \\
\text { networking, network societies, social networks and } \\
\text { network analysis that would be impossible to list here. } \\
\text { One of the most famous gurus of networking is } \\
\text { Spanish sociologist Manuel Castell who defined a } \\
\text { network as the new social morphology of our societies } \\
\text { (Castells, 1996). "A network" was also the shape of } \\
\text { our collaboration: a network of knots we were during } \\
\text { project implementation and each knot also belonged to } \\
\text { other networks different from the "Connecting } \\
\text { Generations" one. In other words, the ties through } \\
\text { which any given social unit, in this case, project } \\
\text { partners, connects, represent the convergence of the } \\
\text { various social contacts of that unit. The enormous } \\
\text { potentiality of networks is their scaling up power. }\end{array}$ \\
\hline Participation & $\begin{array}{l}\text { This is also another, often controversial, the key } \\
\text { concept of our times: it is invocated by all, in different }\end{array}$ \\
\hline
\end{tabular}




\begin{tabular}{|c|c|}
\hline & $\begin{array}{l}\text { degrees, but very little practiced beyond certain circles. } \\
\text { There is, according to the dialogue in "Connecting } \\
\text { Generations," a high degree of hypocrisy about } \\
\text { participation, due to the great allure of the word. It is } \\
\text { used by EU policy makers, national politicians, non- } \\
\text { governmental organizations and associations leaders as } \\
\text { well as others, but it is often just a mask of a very } \\
\text { evident failure of citizens' organizations. In times of } \\
\text { crisis and disaffection in the public space, traditional } \\
\text { participation intended as a set of mechanisms to } \\
\text { express one's own opinion and exert influence on } \\
\text { political, economic, management or other social } \\
\text { decisions often remains at the level of consultation or } \\
\text { information. Even in EU projects participation is often } \\
\text { on paper rather than in reality. Participation and } \\
\text { sharing could have been stronger also in "Connecting } \\
\text { Generations," in particular, some of the partners } \\
\text { involved had less familiarity with the concept of } \\
\text { participating not only in mobility but also in the } \\
\text { governance of the project and the monitoring of its } \\
\text { objectives and expected results. }\end{array}$ \\
\hline Sharing & $\begin{array}{l}\text { This word is, with creativity and solidarity, one of the } \\
\text { three "solution concepts" agreed upon by "Connecting } \\
\text { Generations" partners. We belong to a future of shared } \\
\text { knowledge, shared economy and most of all, shared } \\
\text { destiny. Unless we contribute to change from the local } \\
\text { dimension, with shared solutions, no one will do it in } \\
\text { our place. A project such as "Connecting Generations" } \\
\text { can also be seen as a socio-economic system built } \\
\text { around the sharing of human and physical resources: it } \\
\text { shares creation, production, distribution, and } \\
\text { consumption of intellectual goods and services by } \\
\text { different people and organizations, in eight different } \\
\text { countries. Sharing always existed in human cultures, } \\
\text { and youth and older people have lived different } \\
\text { experiences of it: our older generations shared the } \\
\text { burden of reconstructing Europe after the Second } \\
\text { World War while youth is building a shared global } \\
\text { knowledge repository through open access and } \\
\text { crowdsourcing. }\end{array}$ \\
\hline Solidarity & The crisis has sharpened the sense of urgency to \\
\hline
\end{tabular}




\begin{tabular}{|l|l|}
\hline $\begin{array}{l}\text { review fundamentally the way our society functions } \\
\text { and more often the concept of "solidarity," as opposed } \\
\text { to "competition" is introduced. According to US } \\
\text { activist Paul Hawken (2007), we are experiencing a } \\
\text { rise of a blessed unrest multitude who is, collectively, } \\
\text { claiming for change and a more solidarity-based social } \\
\text { fabric and a more ecological and sober living. In his } \\
\text { words, from billion-dollar non-profits to so-called } \\
\text { "single-person dot causes," these groups collectively } \\
\text { comprise the largest movement on Earth. It is a } \\
\text { movement without leaders, largely ignored by } \\
\text { politicians and the media and organizing, like in } \\
\text { nature, from grassroots. It is happening around us, and } \\
\text { our role as social innovators and educators is to spot } \\
\text { change based on solidarity and give it the visibility } \\
\text { mainstream media would never agree to do. } \\
\text { "Connecting Generations" was mainly about } \\
\text { intergenerational solidarity: it recognized conflicts-of- } \\
\text { interests, of priorities, but defended the primacy of } \\
\text { bonds and common objectives. }\end{array}$ \\
\hline
\end{tabular}

Source: Own elaboration.

\section{Conclusion}

The theoretical framework, as well as the qualitative results of the research presented above, carry a wealth of meaning, input, and suggestions that accompanied the professionals involved in "Connecting Generations" well beyond the end of the project activities. Those concepts are all still very actual, and further experimentation of this action research approach can contribute to the challenge of building empowered, resilient, and inclusive communities from grassroots through adult learning and intergenerational learning. The way we act depends on the idea of Europe we have in mind and in our hearts: for us, it should be a society that values, instead of shunning, a difference of cultures, ages, sex, religion and any other. It should be a society that does not see a certain category of people, be it young, older, migrants or minorities, only on the basis of what they lack or need, but on the contrary on the richness of their approach in a non-standardized community. In the age of liquid fear, using Bauman powerful 
image, learning and dialogue among generations and cultures are an antidote to hate speech and to ignorance and fear that leads to it.

We noticed that "Connecting Generations" had not only connected generations in the seven EU partner countries plus Turkey. It also connected municipalities and regional governments, public and private sectors, professionals and volunteers, local population and migrants and especially different visions of, and actual living in Europe. We all shared a common objective: recognizing how Europe had dramatically changed in its demographic composition, we made a sincere effort to imagine, build, experiment and test innovative practices of intergenerational learning and solidarity that could enhance an enriching dialogue between youth and senior citizens.

Some of the countries involved, Italy and Greece most of all, faced an urgent problem in terms of welfare for senior citizens and "Connecting Generations" was in itself an opportunity to test how, at the local level, lifelong learning policies, could contribute, consistently with economic and social policies, to improve the quality of life not only for the older adults but all.

Putting the accent on research and collection of results has been quite an interesting lesson learned in fact: as mentioned above, learning partnerships were meant to give an opportunity to smaller organizations to strengthen an EU dimension also. The latter are not always prepared to keep pace with the research. They often do not have the intellectual tools to do that since their mission is quite different. On the contrary, bigger organizations, less used to research, might not be so "grass-root" and have still a lot to learn from smaller field-based organizations. Nevertheless, all tried to contribute and certainly, although to different degrees, learned new skills and competencies that have become useful in other EU projects, or in local interventions, especially in terms of self-evaluation.

Coming back to the hypothesis from which this paper has started, we emphasize that:

- Initiatives of non-formal education geared toward intergenerational learning, promoted by civil society organizations, in collaboration with private and public 
stakeholders and supported by EU funds, represent a significant contribution toward cohesion and well-being of communities.

- A transformative education approach is on the basis also of training of what we called "intergenerational trainers," that have the necessary skills, identified in a clear competence framework, to facilitate intergenerational learning in innovative settings and with mixed techniques, from participatory world-café to digital story telling.

- The challenge in front of us appears to be how to link local quality experiences, often scattered and isolated, within a European and transnational dimension. In CONGENIAL, this gap has been filled thanks to the international partnership network, which has also created a fertile field of collaborative learning for operators and learners alike. The activities created visibility and recognition of intergenerational learning activities in local communities and were at the same time recognized at the EU level, through LLP national agencies.

From all the above, developed during the two years of the CONGENIAL project, the significant role that more and more people are gaining in educating communities for the well-being of citizens emerges everywhere. These are communities where education is conceived as shared accountability and a common framework of values, thus raising awareness about the culture of solidarity and inclusion facing the challenges through the reinforcement of the concept of "membership" and the promotion of a greater contact between the school, families and the territory in order to re-launch the social dynamics and to innovate community relationship.

\section{References}

Baschiera, B., Deluigi, R., \& Luppi, E. (2014). Educazione intergenerazionale. Prospettive, progetti e metodologie didattico-formative per promuovere la solidarietà fra le generazioni [Intergenerational education: Prospects, projects and methodologies for teaching and training to promote solidarity between generations]. Milano: FrancoAngeli. 
Bauman, Z. (2008). Does Ethics Have a Chance in a World of Consumers? Cambridge: Harvard University Press.

Becker, G. S. (1964). Human Capital: A Theoretical and Empirical Analysis. New York: National Bureau of Economic Research.

Bengtson, V. L., \& Oyama, P. S. (2007). Intergenerational Solidarity:

Strengthening Economic and Social Ties: Background Paper.

Retrieved from

www.un.org/esa/socdev/unyin/documents/egm_unhq_oct07_ben gtson.pdf

Castells, M. (1996). The Rise of the Network Society: Vol I.

Cambridge, Mass.: Blackwell Publishers.

Denison, E. F. (1966). Measuring the Contribution of Education to

Economic Growth. In E. A. G. Robinson \& J. E. Vaizey (Eds.),

The Economics of Education: Proceedings of a Conference held

by the International Economic Association (pp. 202-260).

London: Palgrave Macmillan.

Dewey, J. (1933). How We Think: A Restatement of the Relation of

Reflective Thinking to the Educative Process. Boston, New

York: D.C. Heath.

Duccio, D., \& Alberici, A. (Eds.). (2004). Istituzioni di educazione degli adulti [Adult Education Institutions]. Milano: Guerini e associati.

European Commission. (2006). The Life Long Learning Programme. Retrieved from http://ec.europa.eu/education/lifelong-learningprogramme_it

European Commission. (2010a). Council Recommendation of

12/05/2009 on EU cooperation in education and training (ET

2020). Retrieved from http://eur-lex.europa.eu/legal-

content/EN/TXT/HTML/?uri=LEGISSUM:ef0016\&from=IT

European Commission. (2010b). Council Recommendation of

$27 / 04 / 2010$ on broad guidelines for the economic policies of the

Member States and of the Union. Retrieved from

http://ec.europa.eu/eu2020/pdf/Brochure\%20Integrated\%20Guid elines.pdf

European Commission. (2013a). Council Recommendation of

22/04/2013 on establishing a Youth Guarantee, (2013/C 120/01).

Retrieved from http://eur-lex.europa.eu/legal-

content/EN/TXT/?uri=OJ:C:2013:120:TOC 
European Commission. (2013b). Social Innovation Research in the European Union: Approaches, Findings and Future Directions: Policy Review. Luxembourg: Publ. Off. of the Europ. Union.

Fabbri, L., Striano, M., \& Melacarne, C. (2008). L'insegnante riflessivo. Coltivazione e trasformazione delle pratiche professionali [The reflective teacher: Cultivation and transformation of professional practices]. Milano: FrancoAngeli.

Freire, P. (1970). Pedagogía del oprimido [Pedagogy of the oppressed]. México: Siglo veintiuno.

Galeotti, G. (Ed.). (2015). CONGENIAL. Connecting Generations: Intergenerational Learning for a More Inclusive Europe. Florence: Edizioni Via Laura.

Gros, D., \& Roth, F. (2014). The Europe 2020 Strategy: Can it Maintain the EU's Competitiveness in the World? Brussels: Centre for European Policy Studies.

Hansen, H. K., Molpeceres, M., \& Rothuizen, J. J. (2012). Lifelong Learning and Participation: A Pedagogical Turn in Social Work and Social Policy. Retrieved from www.hellekroghhansen.dk/Egne\%20manus/Lifelong\%20learnin g\%20and\%20participation\%20a\%20pedagogical\%20turn\%20in $\% 20$ social $\% 20$ work $\% 20$ and $\% 20$ social\%20policy.pdf

Hawken, P. (2008). Blessed Unrest: How the Largest Social

Movement in History is Restoring Grace, Justice, and Beauty to the World. New York: Penguin.

Kotzeva, M. (2015). People in the EU: Who Are We and How Do We Live? Luxembourg: EUR-OP.

Laneve, C. (Ed.). (2005). Analisi della pratica educativa. Metodologia e risultanze della ricerca [Analysis of educational practice: Methodology and results of the research]. Brescia: La scuola.

Lave, J., \& Wenger, E. (1991). Situated Learning: Legitimate

Peripheral Participation. Cambridge, New York: Cambridge University Press.

Lipman, M. (1991). Thinking in Education. Cambridge, New York: Cambridge University Press.

Mezirow, J., \& Taylor, E. W. (2009). Transformative Learning in Practice: Insights From Community, Workplace, and Higher Education. San Francisco, CA: Jossey-Bass. 
Mortari, L. (2009). Ricercare e riflettere. La formazione del docente professionista [Search and reflect: The training of the professional teacher]. Roma: Carocci.

Murray, R., Caulier-Grice, J., \& Mulgan, G. (2010). The Open Book of Social Innovation. London: NESTA.

Roig Vila, R., \& Laneve, C. (Eds.). (2011). La pratica educativa nella società dell'informazione. L'innovazione attraverso la ricerca [Educational practice in the information society. Innovation through research]. Brescia: La Scuola Editrice.

Schon, D. A. (1983). The Reflective Practitioner: How Professionals Think in Action. New York: Basic Books.

Semeraro, R. (2011). L'analisi qualitativa dei dati di ricerca in educazione [The qualitative analysis of research data in education]. Italian Journal of Educational Research. (7), 97106.

Serres, M. (2012). Temps de Crise [Times of crisis]. Paris: Éd. le Pommier.

Stiglitz, J., Sen, A., \& Fitoussi, J. P. (2009). Commission on the Measurement of Economic Performance and Social Progress. Retrieved from www.stiglitz-senfitoussi.fr/documents/rapport_anglais.pdf

World Health Organization (WHO). (2002). Active Ageing: A Policy Framework. Retrieved from www.who.int/ageing/publications/active/en/index.html 

Suggested Citation: Rasnača, L., \& Rezgale-Straidoma, E. (2017).

Intergenerational Cultural Programs for Older People in Long-term Care Institutions: Latvian Case. In Ł. Tomczyk \& A. Klimczuk (Eds.), Selected Contemporary Challenges of Ageing Policy (189-219). Kraków: Uniwersytet Pedagogiczny w Krakowie. Doi: 10.24917/9788380840911.9

\section{LĪGA RASNAČA ${ }^{1}$}

\section{ENDIJA REZGALE-STRAIDOMA ${ }^{2}$}

\section{Intergenerational Cultural Programs for Older People in Long-term Care Institutions: Latvian Case}

Abstract: An ageing population is a global phenomenon that takes place in Latvia, too. The active ageing policy is a social response to social challenges caused by demographic changes. Growing generational gap is a challenge to all "greying societies" in Europe and Latvia in particular. The active ageing policy is oriented to provide possibilities for older adults to live independently. However, long-term care institutions (LTCIs) remain necessary, especially for those who live alone and have serious health problems. LTCIs are mostly orientated to provide primary needs and health care. People regardless of their age also need a social and cultural life, but for older people who live in LTCIs, it is insufficient. The study shows those who are residing in LTCIs settings are subject to everyday routine. LTCIs care provision is very much dependent on the authorities of the institution. The insufficient level of interaction between older people and the more active part of society prevents the finding of effective ways of achieving that the care in LTCIs is in accordance with the active

\footnotetext{
${ }^{1}$ Līga Rasnača, University of Latvia, liga.rasnaca@lu.lv.

${ }^{2}$ Endija Rezgale-Straidoma, University of Latvia, endiarezgale@gmail.com.
} 
ageing policy. The study aims to find out ways how intergenerational cultural programs of professional and amateur activities are implemented in LTCIs. The study uses a qualitative approach to explore how LTCIs intergenerational cultural programs are helping to keep our youngest and oldest generations connected.

Key words: Intergenerational Solidarity, Cultural Programs, Active Ageing, Long-Term Care Institution, Generational Gap

\section{Introduction}

The ageing population is a global phenomenon of the twenty-first century, and rapid science and technology developments are one of the consequences among others. People are capable of living longer lives due to "medical discoveries, new surgical technologies and decline in infant mortality and advanced treatment mode for previously fatal diseases" (Miller, 2002, p. 4.). "The number of people aged 65 or older is projected to grow from an estimated 524 million in 2010 to nearly 1.5 billion in 2050, with most of the increase in developing countries" (WHO, 2011). The rapidly ageing population is a challenge for both global and local policy makers. The long-term care and health care for older people have become a burning issue as never in the whole world, and Latvia is not an exception. The Organization for Economic Co-operation and Development (OECD) reports that population ageing will have an impact on government budgets. The overall prognosis is that by 2050 , it expects to exceed one-fifth of national income in most of the OECD countries (OECD, 2011).

According to the World Health Organization (WHO) strategy, one can conclude that rapidly ageing population is contributing to increasing demand for social care services (WHO, 2016) and bringing new challenges in long-term care for older people. Latvia also is one of the European countries whose population consists of almost one-fifth of older people. The proportion of older people in Latvia has increased since regaining the independence in 1991 (CSB, 2016). The old-age population in 2013 (population aged 65 or over) in Latvia was 18.9\% with a tendency to increase by 2030 up to $25.5 \%$ (European Commission, 
2015 , p. 342). The increasing size of older people results in the growth in public expenditure in this group. It forces policy makers to find new solutions that relate to issues considering the enhancement of life satisfaction for older adults (Toepoe, 2011). Similar problems are in Latvia, too and the biggest challenge for policy makers is how to make the more satisfactory living in LTCIs for older people. "Alienation in communication and mutual lack of knowledge exchange between the generations reduce the chances for satisfactory mutual relations between the younger and older family members" (Republic of Slovenia Ministry of Labour, Family, and Social Affairs, 2010). Rapidly ageing population brings in new challenges on how to establish new relations between family, community, and residential institutions. It explains the increased need for financial resources in care for older adults and changes in the nature of it (Macionis \& Plummer, 2008) by calling "for a holistic approach based on a shared vision of a society inclusive of all ages" (AGE Platform Europe, 2010).

People regardless of their age also need a social and cultural life, but for older people who live in LTCIs, it is very limited. There are a wide variety of intergenerational programs that promote a healthy and active ageing for older adults in their communities in Latvia, but the coverage and availability of programs are limited due to lack of financial support, human resources, and appropriate infrastructure in municipalities. Most of the time the initiators and organizers of these programs are nongovernmental organizations (NGOs), churches, schools, and various interest clubs for example interest clubs for older adults. The active ageing policy is oriented to provide possibilities for older people to live independently. LTCIs are mostly orientated to provide primary needs and health care. Helen Featherstone (2014), the Senior Manager at Arts Council England, emphasizes that the arts can be used in an efficient manner to deal with many issues encountered by older adults, for example with the most common among older people such as loneliness. Most of the cultural programs are supervized by aged care services. There is an insufficiency of systematized information on how art and culture are used for intergenerational solidarity programs. 
The study presented in this chapter aims to find out ways how intergenerational cultural programs of professional and amateur activities are implemented in LTCIs. Authors particularly are interested in what kind of cultural programs are implemented in LTCIs to provide healthy and active ageing for older adults considering the fact they are living in institutionalized settings. What kind of particularities can be identified in institutionalized settings to make it possible for intergenerational cultural programs to happen? Research tasks are: to analyze main concepts, political documents, and realization of intergenerational cultural programs, to describe research method, to analyze findings and to start a discussion.

The study is based on five research questions. These are: (1) How intergenerational cultural programs for older people in LTCIs are organized? (2) What is the spatial layout of the place where intergenerational cultural programs are held? (3) How are the intergenerational cultural programs happening? (4) Who undertook an initiative to organize intergenerational cultural programs? (5) Who are the participants of intergenerational cultural programs?

Authors are using a qualitative approach to explore how LTCIs intergenerational cultural programs are helping to keep our youngest and oldest generations connected. The study consists of a theoretical framework that supports the research, methods of data collection, description of the situation of organizational and financial framework concerning cultural programs for older people in LTCIs, analysis of interview results, discussion and conclusions on main findings are drawn in the final part of the article.

\section{Theoretical Framework}

To support this study in this section authors are describing main concepts: intergenerational solidarity, generational gap, active ageing, long-term care institutions (LTCIs) and cultural programs.

Intergenerational solidarity means a social cohesion between generations and active ageing encouraging older people to be active in society and motivate them to healthy ageing (OECD, 2011). The European Union (EU) is aware of the importance of intergenerational solidarity. The European Day of 
Solidarity between Generations in 2012 (EY 2012), was an excellent opportunity to make many visible initiatives across the EU and "remind of the need for greater solidarity and cooperation between age groups in our ageing societies" (WeDO, 2012). Intergenerational solidarity means intentional interaction between two or more persons of different ages (Amparo Cruz-Saco, 2010). It encourages for both young and old to gain new knowledge, to develop new skills, exchange experiences. That can be achieved by promoting volunteer approach by motivating people of different generations to live, work and attend various cultural events together (Latvijas Republikas Labklājības Ministrija, 2012). The authors are acknowledging that the intergenerational solidarity is a necessity for the cohesion of every community living in greying societies.

To stabilize intergenerational solidarity, it is also important the renegotiation of the balance between continuity and innovation over time through the succession of one generation by another. Solidarity between generations is best understood within the context of shared expectations and obligations regarding the ageing of individuals and the succession of generations (Bengtson \& Oyama, 2007). Intergenerational solidarity is more often experienced within a family of an older adult, then with nonbiologically linked society members from different generations. However, there is a need for mobility and involvement of all society members in all age groups. The primary challenge of this new paradigm, called intergenerational solidarity, is how to create connections among non-biologically linked older and younger people that could promote the social growth, learning and emotional stability that often characterizes relationships between older and younger family members (Newman \& Hatton-Yeo, 2008).

"Intergenerational programs refer to activities or programs that increase cooperation, interaction or exchange between any of two generations." Since the late 1970s has been growing interest in intergenerational programs and they are not one type of planned actions any longer (Kaplan \& Sanchez, 2014). OECD acknowledges intergenerational solidarity "as a desirable value in itself." Intergenerational solidarity is achieved when generations 
are respecting each other's views and can compromise between each other on the way forward (OECD, 2011). It also means bonding between generations and it can be achieved by reflecting "personal wishes and material goals, emotional bonds, and rational justifications, altruism and self-interest, caregiving, and care to receive" (Amparo Cruz-Saco, 2010). However, fast-paced lifestyle is making this connection between young and old recently less common. That can lead both young and old to social isolation and miss opportunities to learn from one another (BC Care Providers Association, 2009). The problem that occurs within organizing intergenerational programs is difficult to develop high-quality intergenerational activities (Generations United, 2006). Intergenerational programs are not only playing an important role in society by bringing generations together but also provide active ageing for older adults.

The intentional interaction between generations helps to build intergenerational relationships. This matter was called to attention in the 1960s when for the first time was addressed the conflict between generations, and it was called the "generation gap" (Bengtson \& Achenbaum, 1993). It is an inevitable barrier for the communications between the young and the old ones. In the late 1970s, intergenerational programs were included in social planning models whose purposes were to connect older and younger people in formal settings (Newman \& Hatton-Yeo, 2008). They are playing an important role in recognizing our basic human need to connect with others (BC Care Providers Association, 2009). One of the main reasons for these programs is to bridge the perceived generation gap between the young and the old but who are young at their heart (Davidson \& Boals-Gilbert, 2010). Intergenerational programs are built on beneficial activities for both generations. The designed activities are for achieving specified program goals that each participant can benefit from.

Generational gap (in some literature it is also called generation gap) is a concept used to point out diversity between younger and older generations regarding cultural norms (Mather, 2007). The meaning of generational gap mostly stands for an inevitable barrier for the communications between the younger and the older generations. The reason for this conflict to become 
visible as consequences of urbanization, industrialization, and family mobility (Bengtson \& Achenbaum, 1993). In the 1960s scholars used this concept to find an explanation and describe differences in culture between parents and their children. The cultural differences mainly identified in cultural tastes in music, fashion, and technology among these two generations (Mather, 2007). Since that time has been implemented various programs and initiatives to bring all generations closer together.

The active ageing policy is a social response to social challenges caused by demographic changes. The WHO defines "active ageing as a process of optimizing opportunities for health, participation, and security in order to enhance the quality of life as people age. It applies to both individuals and population groups" (WHO, 2002). The Third Age is a new concept introduced within the policy of active ageing. It stands for the idea of activity in the post-retirement years. "The Third Age is characterized as a time of growth and personal development when individuals would have both the resources and the energy to give to new activities and learning" (Lloyd, Tanner, Milne, Mo Ray, Richards, Sullivan, Beech, \& Phillips, 2014). Active ageing one also can understand as a healthy, successful, positive, or productive ageing.

The fact that long-term care services are fragmented (private and public; local and centralized) could face a difficulty to materialize the policy of an active ageing in LTCIs. With an ageing population, early retirement options sometimes can be limited, and active ageing policy encourages older employees to remain in the labor force longer (The World Bank, 2015). Active and healthy ageing is crucial not only for active older adults living independently but also for those older adults who reside in LTCIs (Rezgale-Straidoma \& Rasnača, 2015; Rezgale-Straidoma \& Rasnača, 2016). The active ageing policy stands for providing more flexible work arrangements, including increased part-time employment both for workers transitioning to retirement and care providers.

Long-term care institutions (LTCIs) are "social institutions which provide a person who cannot take care of himself or herself due to old age or state of health, as well as orphans and children, left without a parental care with housing, 
full care and rehabilitation" (Latvijas Republikas Saeima, 2002). The authors are interested in LTCIs for older people, but general meaning and purpose of LTCIs can be applied to all social groups mentioned in the definition above. Generally, in LTCIs are admitted people whose safety and wellbeing is at risk due to their inability to take care of themselves (Alders, Comijs, \& Deeg, 2016). LTCIs put not only a financial strain on society but also challenges authorities on how to provide the appropriate health and social care, housing, and suitable environment for older adults so that they could maintain the quality of life as high as possible. Historically long-term care has always been one of the biggest issues to human life course. It is only quite recently that long-term care is addressed as a specific social risk, requiring the intervention of the welfare policy (Österle \& Rothgang, 2010). Several stakeholders, the central and local government, NGOs, and private organizations, are involved in the provision of longterm social care for older people.

Cultural programs can consist of a wide variety of art programs. The cultural programs are one of the forms of creative capital including creativity, originality, and artistic value. "Creative capital of older people must be understood as their activities and their work, that could be an opportunity for maintaining a healthy lifestyle ....and enjoying a high quality of life" (Klimczuk, 2015, pp. 26-31). They range from painting, writing, poetry, jewelry making, and material culture, to music (Cohen, Perlstein, Chapline, Kelly, Firth, \& Simmens, 2006). Music as a cultural program can include older people singing in the choir or the ensemble. Very often LTCIs in cultural or art programs call "activity" because of its format, which is a brief and time-bound event. LTCIs have a lot to choose from on how to introduce arts experiences to its residents. One way is to bring in the arts to LTCIs, for example inviting artists to perform at LTCIs. Another option for providing cultural activities for older people in LTCIs could be to have an artist or artists as a staff member who can come up with own ideas for various art and culture activities. Some LTCIs are combining both options to provide older people with cultural life (Rollins, 2013). All cultural programs are based on participation and interpersonal interaction of older people with 
others. That requires social engagement, too (Cohen et al., 2006). They are social tools that offer at least two generations the opportunities to interact with each other and to be active participants in the community (Generations United, 2007). The intergenerational cultural programs for older people in LTCIs play an important part in bridging the generational gap.

Theory of institutional ecology can use to analyze intergenerational cultural programs in LTCIs. The theory focuses on special layout and social space, which is occupied by the organizational institution or process (Abrutyn, 2012; Piszcek, 2014). It is very important for the intergenerational cultural programs provided by different actors (state, local government, and private organizations) and various spatial layouts in LTCIs.

\section{Data and Methods}

The study design is case study focusing on the organizational framework of intergenerational cultural programs in the state, local government and private LTCIs for older people. The research methods are documented analysis and semi-structured interviews.

Documents governing the social welfare system in Latvia were reviewed and analyzed: EY 2012, the Law on Social Services and Social Assistance which lays down the principles of providing social services and the range of people eligible to receive such services, Regulations on state and local government social care institutions, the Convention on the Rights of Persons with Disabilities and several examples of intergenerational cultural programs for older adults in Latvia provided by NGOs and local governments.

Data were collected by conducting ten semi-structured interviews with cultural event managers in LTCIs and both professional and amateur artists. Interviews included main questions that helped to get the answers to the research questions:

- What is the way, how organizing intergenerational cultural programs for older people in LTCIs?

- What is the spatial layout of the place where intergenerational cultural programs are held? 
- How are the intergenerational cultural programs happening?

- Who undertook initiative to organize intergenerational cultural programs?

- Who are the participants of intergenerational cultural programs?

Interviews were done in May and June of 2016 during the visits to LTCIs and taking part in some intergenerational cultural programs. Interviews were done in all three available kinds of LTCIs in Latvia- state, local government and private. The LTCIs chose based on authors' personal network. Authors of study visited five LTCIs: two private institutions "Upe" and "Vilnis" in a rural area, two institutions of local government "Ezers" and "Koki," and one state institution "Krasts." Due to very sensitive issue and the fact that there are not so many LTCIs in Latvia, the real names of LTCIs in this study are changed.

The subject of interviews is involved with the financial matter, and that makes it a susceptible issue. Interviewed respondents preferred to remain anonymous and ask for guarantees of confidentiality, describing it as self-protection in the professional and administrative environment. Five cultural event managers in all five LTCIs were interviewed while only two of them were staff members ("Krasts" and "Ezers").

Their work obligation is to take care of cultural life for older people. That includes organizing intergenerational cultural programs by inviting various artists and including older people in a variety of art and musical activities (e.g., workshops, concerts, and trips to museums). The cultural event manager from "Krasts" in the past worked a lot with artists and still currently works as the master of ceremonies on weekends, and that is helping a lot to find volunteers to participate in intergenerational cultural programs in "Krasts." The cultural event manager from "Ezers" previously was a musician that is why he is enjoying his current job very much. The cultural event managers who were interviewed in the second institution of local government "Koki" was a social rehabilitator by occupation in this institution but started to work with older adults as volunteer ten years ago. Based on his enthusiasm and 
care for older people he very actively participates in organizing cultural life in "Koki."

In the private LTCIs, the cultural event manager portrait slightly differs. In "Upe" the cultural event manager was the owner of this institution and takes an active participation in organizing cultural events and intergenerational programs for older people using his personal contacts with various artists and organizations. The last expert of LTCI "Vilnis," who previously worked as a teacher, admits that loves his current job. At the same time, semi-structured interviews were done with an artist who participated in intergenerational cultural programs on that day in LTCI. The artists who were interviewed were professional pianists, singers, and actors. They also wanted to stay anonymous in this study.

\section{Organizational and Financial Framework Concerning Cultural Programs for Older People in LTCIs}

LTCIs in Latvia are still the most important way to take care of older people in comparison to other EU countries. According to gathered data by Ministry of Welfare of the Republic of Latvia on average, $83 \%$ of people who are in need for social services receive them in institutions. Only $17 \%$ receive social services through other alternative ways (Latvijas Republikas Labklājības Ministrija, 2013). Older people draw up the largest number of people who need to be institutionalized. The Central Statistical Bureau of Latvia (CSB) reports that 567448 people are older adults out of 1.978 million of the total population in Latvia (CSB, 2015). The older population is considered aged 65 and older but in this study authors referring to older people who reside in LTCIs in Latvia. They are not necessarily all above the age of 65 because retirement age used to be 62 years and it is increasing every year in Latvia, authors are considering the fact that majority of older people residing in LTCIs are people who reached their retirement age but some of them can be under age of 65 . Recipients of old age pensions at the end of the year 2015 are 466700 (CSB, 2015). About 137000 older people in Latvia are in need of social care. The reality is that only 10000 older people receive LTCIs and 11 600 receive care at home (Bērziņš, 2015). 
Long-term care for the many of older people is one of the major solutions where to spend their last days of life in current Latvian situation. In order to improve services for older people, it requires considering each component of care because many older adults are using multiple services (Oliver, Foot, \& Humphries, 2014). Intergenerational cultural programs must be one of the elements to make lives satisfactory for older people in LTCIs. The year of 2012 was European Year for Active Ageing, and Solidarity between Generations (Tymowski, 2015). Latvia also took part in this initiative by organizing various intergenerational cultural programs in LTCIs (Latvijas Republikas Labklājības Ministrija, 2011). However, after the year 2012 to some activities continuity did not follow. The Convention on the Rights of Persons with Disabilities Article 30 "Participation in cultural life, recreation, leisure and sport" states that "States Parties recognize the right of persons with disabilities to take part on an equal basis with others in cultural life, and shall take all appropriate measures to ensure that persons with disability are entitled to participate in cultural activities" (United Nations, 2006). Latvia signed this resolution in 2008 (Latvijas Republikas Saeima, 2010). Since there are many older people with a disability, then this article in Convention authors apply to older adults, too. However, in Latvian Law on Social Services and Social Assistance (Latvijas Republikas Saeima, 2002) one cannot find an article where would be mentioned that older people in LTCIs must be provided with cultural programs. That explains why LTCIs do not have financial funds for cultural intergenerational cultural programs and currently are purely dependent on volunteers or some funding provided by the local government or supported by some initiative as it was in 2012.

\section{Analysis of the Research Results}

The research results show that institutionalized and informal way of organizing intergenerational cultural programs is overlapping with each other. The main findings are that in participating intergenerational cultural programs for older people in LTCIs are both professional and amateur artists. Initiative in participating and organizing intergenerational cultural programs come from 
both cultural event managers of LTCIs and volunteers, for example, church communities, student organizations and other amateur collectives in fine arts. The cultural programs are aligned with the artists and authorities of the LTCIs in advance. There is no single model for all three types of LTCIs how to organize intergenerational cultural programs. The main goal of these cultural programs is to achieve active and healthy ageing in LTCIs.

Further, the results of the study will be analyzed. There will be clarified answers to the main semi-structured questions and identified major issues with organizing intergenerational cultural programs. Analysis will be structured into five sections that are made according to research questions: (1) Spatial layout of the place for intergenerational cultural programs to be held; (2) Initiative to organize intergenerational cultural programs in LTCIs; (3) Participants of intergenerational cultural programs in LTCIs; (4) Participants of intergenerational cultural programs in LTCIs; and (5) How the intergenerational cultural programs are happening?

Spatial Layout of the Place for Intergenerational Cultural Programs to Be Held

Spatial layout differs between LTCIs. If LTCIs were built when Latvia was part of the Soviet Union, then for concerts and other cultural events there is a special auditorium for bigger events and several rooms for workshops. Auditoriums are designed very similarly to those concert halls, what is very common in most of the small towns in Latvia (Figure 1). All of them have a stage for artists and seats are placed in rows where the audience (in this case older people of LTCIs) can have their seat. Most of the auditoriums have at least one piano or keyboard. One of the tasks for cultural event managers is to keep an instrument in good shape. Keeping an instrument in good shape often depends on the financial availability of LTCIs. It is an extra expense for LTCIs to maintain the instrument, for example, piano tuning. That explains why not always instruments in LTCIs are in good condition. Some of these institutions were also equipped with sound equipment, too. 
Figure 1 Spatial Layout of the Place for the Intergenerational Cultural Program in State LTCI "Krasti." Artists Are Presenting the Musical Program and Communicating with Older People by Sharing Stories to Each Other

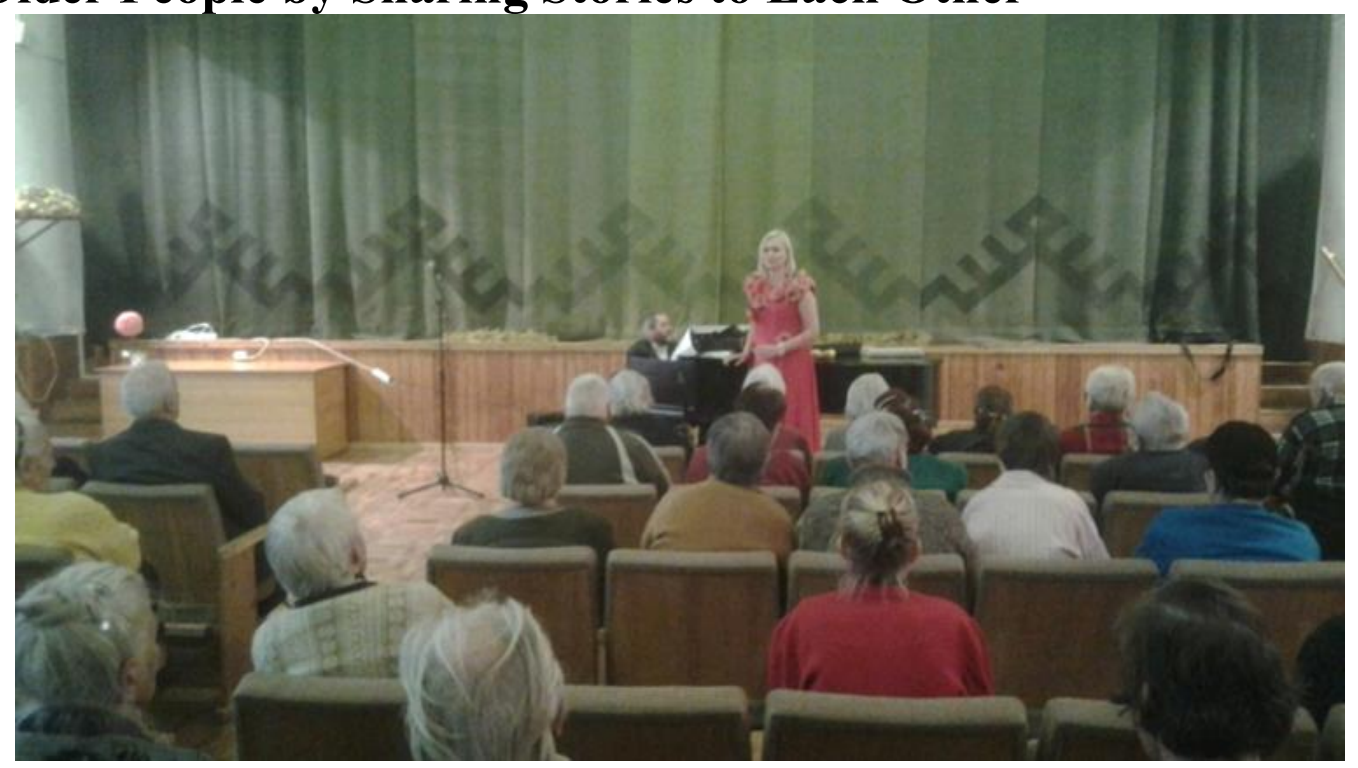

Source: Authors' archive.

It is more problematic to find the appropriate space for events in private LTCIs. Those two private LTCIs that were visited had a different spatial layout for an intergenerational cultural event. LTCI "Upe" previously was a hospital and owner of this institution had chosen a big operation room as a facility for cultural programs (Figure 2). This institution does not have even a piano, so artists have to bring their own instrument. In addition, this room does not have a stage that would classically divide artist's space from the audience. Older people are sitting very cramped in this former operation room (Figure 3), and it is not ventilated, so during an event gets very hot in there. Another private LTCI "Vilnis" previously was a hotel. It also does not have a special place for cultural programs. Usually, an hour-long intergenerational cultural program been held at lunchtime, and the facility that is used for that is the dining room of the LTCI. Very disturbing is that during the event one can hear on a kitchen staff preparing lunch. According to the theory of institutional ecology, the insufficiency of resources such as restricted space and 
organizational abilities are limiting the quality of intergenerational cultural programs in LTCIs.

Figure 2 Spatial Layout of the Place for the Intergenerational Cultural Program in Private LTCI "Upe." Students from Several Student Organizations Are Visiting LTCI and Performing for Older Adults as Part of the Intergenerational Program

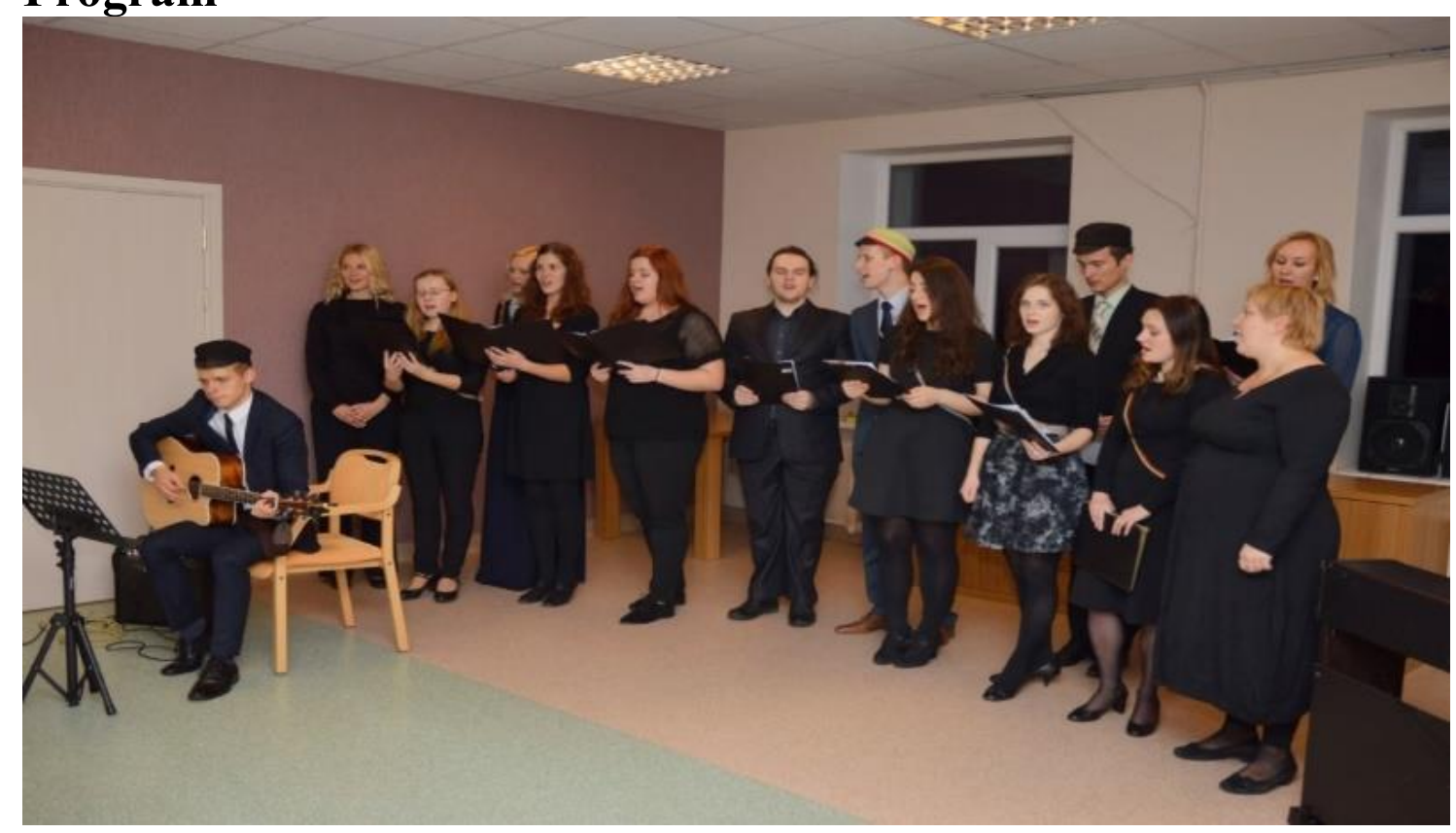

Source: Authors' archive.

Initiative to Organize Intergenerational Cultural Programs in LTCIS

Initiative to organize intergenerational cultural programs primarily based on self-initiative of the cultural event managers in the state and the local government LTCIs and on owners of the institution in the private LTCIs. In both cases, cultural event managers or owners of LTCIs use their personal contacts to persuade artists to perform in LTCIs. The cultural event managers are positively acknowledging active involvement in intergenerational cultural programs provided by churches, schools, student organizations, various amateur collectives, and interest clubs. The most active time of the year when many people from the community are interested in performing in LTCIs is Christmas time. During the Christmas time, the cultural life in LTCIs is at its 
peak. However, after that, the cultural event managers admit that in order to continue with the same pace of the activities in LTCIs initiative first must come from the cultural event managers themselves. It is seldom when the initiative to perform in LTCIs comes from the professional artists first. The cultural event managers also point out that there is no financial support available for these cultural programs. The artists' participation in intergenerational cultural programs for older people in LTCIs is based on volunteering.

Figure 3 Spatial Layout of the Place for the Intergenerational Cultural Program in Private LTCI "Upe." Older Adults Are Participating in the Intergenerational Program

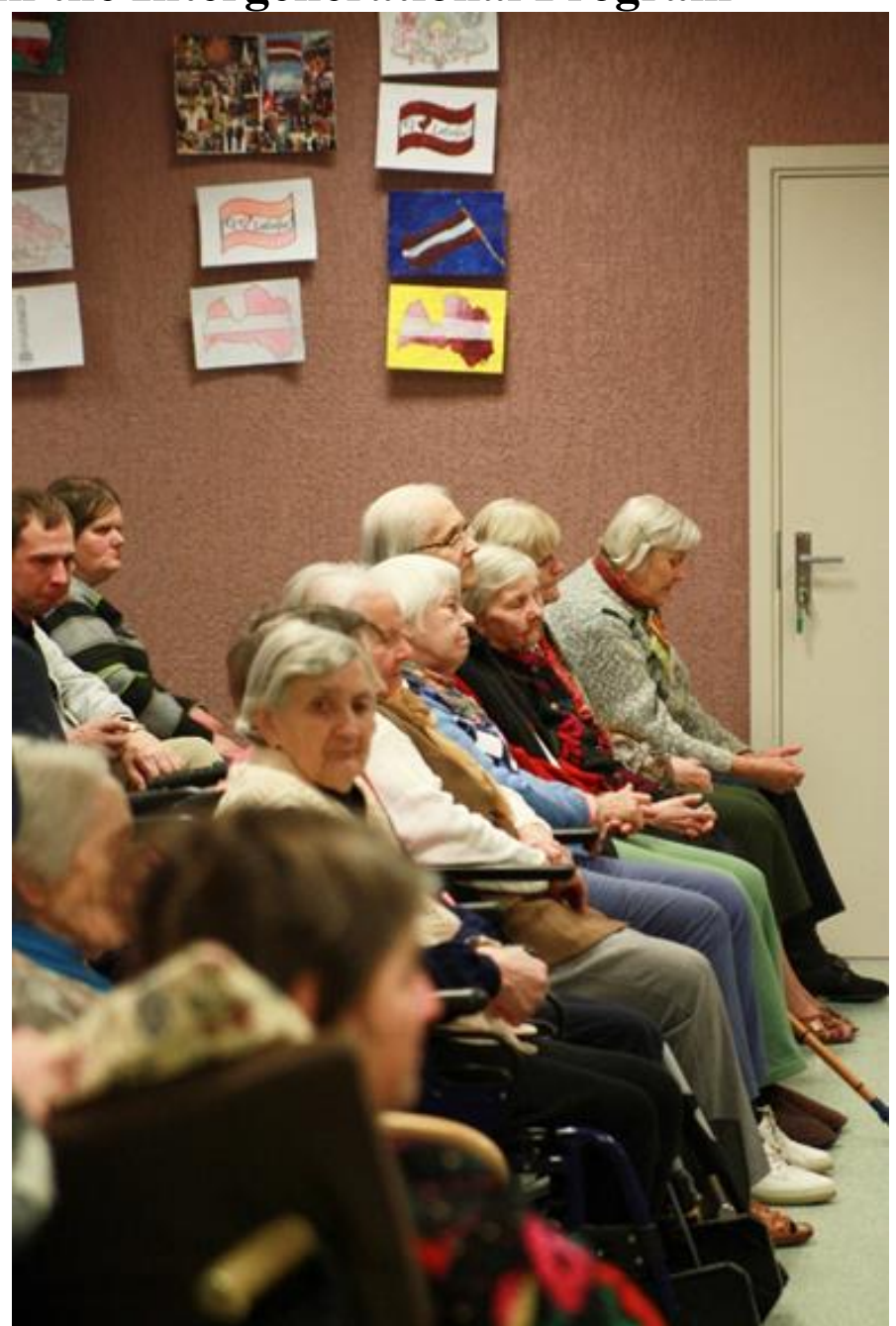

Source: Authors' archive.

The Way to Organize Intergenerational Cultural Programs for Older Adults in LTCIs 
Intergenerational cultural programs in each of LTCIs very much depend on various aspects such as enthusiasm of competent staff or cultural event manager, active participation of older adults, financial availability to carry out these cultural programs, community, and local government support, and voluntary participation. The cultural event manager of LTCI "Krasti" remembers that in the EY2012 there were many different cultural activities in LTCIs in Latvia. The main reason for such an active participation of community and interest of various artists to participate in intergenerational cultural programs was the financial grants for various projects to promote active ageing and intergenerational solidarity in LTCIs. That year LTCIs and local governments were able to get funding for various artists for example musicians, actors, and painters and pay them for their work at LTCIs. Four years later when these interviews were done, cultural event managers pointed out that the situation is dramatically changed. As it is already analyzed in the previous section of this study that there is not provided additional funding for cultural events in LTCIs. It means that since the year of 2012 most of these activities that started in 2012 discontinued, and currently these intergenerational cultural programs depend on the personal enthusiasm of cultural event managers in LTCIs and voluntary nature of each community member.

Another important issue the cultural event managers pointed out that older people who are reaching a certain age are losing interest to participate in intergenerational cultural programs. The cultural event managers are persuading and motivating them to take part in the intergenerational cultural programs. The cultural event managers of LTCIs are regularly reminding to older people long before coming up a new event or activity in LTCIs. Preparing for an artist to visit LTCIs and give a performance, cultural event manager prepares posters with information about the event that is coming up and every day for a whole week is making an announcement over the internal radio.

Very often, some of older adults are not able to participate in an event or activity because they have dementia or disability. Those with severe dementia condition need personal assistance in order to attend an event. In the state LTCIs, there is a shortage of 
staff members in order to assist each of residents who are in need that is why some older persons have to stay in their rooms. The slightly different situation is in private LTCIs. There are lesser older persons, and staff can pay better attention to each older adult (but not in all cases, private not always mean better). Some private LTCIs are doing a better job by attracting young people who are temporally working in LTCIs as volunteers. Older people with some physical disability are also deprived of attending an event or participating in some activity because of a shortage of wheelchairs and some other helping aids for them to be mobile.

The cultural program an artist prepares himself or herself in advance and discusses it with the cultural event manager before the event. The length of the intergenerational program is important, too. Usually, it must not be longer than an hour because it is difficult for older people to concentrate their attention for a longer period. The timing of activities is just as important as the length of the intergenerational cultural program. Mostly the cultural event managers preferring the time for an activity before older people will have lunch. It is important that the activities are not overlapping in the same LTCI.

\section{Participants of Intergenerational Cultural Programs in LTCIs}

Participants of intergenerational cultural programs in LTCIs are very different. Main participants are older people residing in LTCIs, but those who are visiting LTCIs during the cultural programs can vary from an amateur artist to a very professional. The age differences between older adults and artists are not always the same. For example, when children from school or student organizations are visiting LTCIs then we can talk about meeting young and old generations. During their visits, young people are singing and playing music. The music they are playing most of the time is a popular music what young people on that age are listening. This is a good opportunity for older people to get to know perhaps the new music genres. Some professional artists are invited who are the same age as some of older residents of LTCIs. Usually, they are some actors or former singers who are famous still acting in TV plays or singing in concerts that are broadcasted on the television. These artists are not only contributing to the 
intergenerational cultural programs, but they are a very good example to others for active ageing, too.

Some professional artists are limited to give an outstanding professional performance because very often accompanists are refusing to perform free of charge. In this case, sometimes the cultural event managers are looking for a donation from a local store next door or paying a little amount of money from their own pocket. One example was mentioned when an artist was performing in LTCIs and paying himself or herself to the accompanist.

\section{How Are the Intergenerational Cultural Programs Happening?}

In all LTCIs which authors visited intergenerational cultural programs took place before lunch. The cultural event managers explained that in the first half of the day, older people have more energy and they can better concentrate than after lunch. From an artist is required prepared scenario of the coming up event. For example, if they are musical performances then artists are required to send a list of songs beforehand and to prepare a storyline or socalled scenario with text between songs in order to make it less formal that way is avoiding usual concert format and making it more interesting for older adults. The performance must not exceed one hour in length. In order for an intergenerational interaction to happen, an artist will have to make a dialogue with older people of LTCIs. At least half an hour before the event, older adults are starting to take seats in the auditorium. The introduction before the event is necessary. Usually, the cultural event manager or another person in charge (it also can be an active older person who has become an authority in LTCIs) introduces with an artist and tells a little bit about him. The rest cultural event manager leaves for an artist himself or herself to tell. Generally, older people are very curious about artists' personal life, and the artist must be prepared to answer to all kinds of unexpected questions. The artist must be prepared that some older people in the auditorium have dementia and not all of them can sit still for an hour. They might walk around and make comments while the artist is performing. When performance is finished, some of older 
people are willing to talk a little bit more with an artist and a lot of them, want to take pictures with the performer.

\section{Discussion}

The aim of the study is to find out the ways, how intergenerational cultural programs of professional and amateur activities implement in LTCIs. Older people in LTCIs are population group that has to be involved in active ageing policy implementation processes. The important issue is how to provide regularity of the intergenerational cultural programs for older people living in LTCIs. The study shows that it mostly depends on the initiative of the event managers of LTCIs. It also depends on the interest of both older people and the professional or amateur artists to participate in the intergenerational cultural programs in LTCIs.

Normative acts, instructions, regulations on LTCIs do not foresee that the cultural programs as such are a necessity for older people living in LTCIs. The regulations do not state that the intergenerational cultural programs must be regular for older people in LTCIs. The focus of long-term care for older people is to be able to provide for them basic needs. Authors believe that older people who stay in LTCIs also deserve some quality of life more than just satisfying their basic needs (room and board). Older people must have some activities and some "food for soul" in order to have that. The intergenerational cultural programs can be one of the ways, how to improve living conditions for older people in LTCIs.

In the literature review authors welcoming, that the importance of the intergenerational solidarity and the intergenerational cultural programs is acknowledged. For example, there is an emphasis on the importance of the interaction and the meaning of the solidarity between generations; there is an emphasis on the necessity to increase cooperation, interaction, or exchange between any of two generations. Although the fact how important it is to older people who live in LTCIs to have these intergenerational cultural programs is not explored and authors could not find offered solutions on how to achieve the intergenerational solidarity and how to implement 
intergenerational cultural programs, and to make them regular for older people in LTCIs.

Authors in this study want specifically to point out the importance of intergenerational cultural programs for older people in LTCIs. These programs for older people are necessary just as much as their basic needs in order to avoid daily routine, suffering from boredom, and preventing them from feeling abandoned in LTCIs.

From the perspective of the theory of institutional ecology, study shows that the spatial layout where intergenerational cultural programs will take place is very important, too. The paradox is that older people not always got their basic needs to the best quality and some things were even lacking in LTCIs during the Soviet Union, but at the same time in all LTCIs had the special auditorium for the cultural programs. Study proves that in LTCIs built during the Soviet Union, they all had an auditorium for the cultural programs. The auditoriums are missing in those LTCIs' buildings, what previously was something else, for example, a hospital or a hotel.

Authors think that some elements of the social time experience are respectful in organizing LTCIs. The suggestion is for the architects to consider the specific setup of LTCIs when they plan to build new LTCIs.

The intergenerational cultural programs are a necessity for every human being, regardless of his or her age. Another aspect that the intergenerational cultural programs importance for older people in LTCIs is underestimated for the reason that it brings the new changes in daily routine in lives of older people in LTCIs. Living in LTCIs older people are living in restricted conditions both environment and society. However, from a medical perspective, there are authors who are writing about the importance of change for those who live in restricted settings. The option that these changes can achieve with cultural programs, and particularly in LTCIs settings it would be well achieved with intergenerational cultural programs is not a common opinion that would be encouraging further discussion and motivating to take some further action. The active ageing policy foresees various 
activities for older people, including for those who reside in LTCIs. The study shows that LTCIs only partly follow this policy.

Every individual is in need for the cultural programs and interaction with different people for legitimate reasons. The study shows that the cooperation between generations not regulated in LTCIs. The security of older people is the most important in LTCIs, but the locked door of the LTCIs do not encourage interaction between generations and implementation of the active ageing policy. Authors associate the setting of LTCIs to fit to the style of the total institution. This institutionalized setting does not encourage intergenerational solidarity and realization of intergenerational cultural programs for older people.

Currently, people who are organizing intergenerational cultural programs are participating voluntary. There is not defined demand for cultural event manager and for a social worker to have competence in the event organizing. People who are organizing cultural events in LTCIs selected for this job position randomly. LTCIs do not have any criteria on what previous experience must one have in order to fit to the position being a cultural event organizer in LTCIs.

The study shows that after EY2012 there are limited possibilities to follow active ageing policy in LTCIs. The national and the local authorities should take measures to encourage and support citizen-based initiatives and volunteering activities, including those involving in the intergenerational cultural programs. Cooperation between communities and the sharing of best practices and experiences could promote by local governments, LTCIs and other organizations (such as NGOs, churches, schools, and student organizations) who are involved in these programs. The implementers of public policy should support intergenerational cultural programs by promoting community engagement and encouraging volunteering. It is very important that the intergenerational cultural programs comprehend various groups of older people including those who reside in LTCIs. It is obvious that there is a deficiency of intergenerational solidarity programs between younger and older people, including cultural programs, in LTCIs and that is why there is a necessity to research the topics concerning these programs. 


\section{Conclusion}

The implementation of intergenerational cultural programs depends on specific management, staff position, spatial layout, financial availability, and free will and enthusiasm of all participants.

The WHO defines "active ageing as a process of optimizing opportunities for health, participation, and security in order to enhance the quality of life as people age. It needs to be applied to older people, LTCIs residents as a special group." Intergenerational cultural programs are one of the ways, how to involve them in active ageing processes.

The following conclusions can be drawn based on document analysis concerning intergenerational cultural programs for older people in LTCIs and results conducted from semi-structured interviews done with LTCIs" cultural event managers and artists who participated in these events or activities.

Interviews with the cultural event managers confirm that there would be a need for intergenerational cultural programs in LTCIs on a regular basis. The cultural event managers' enthusiasm and voluntarily by artists does not provide this regularity of these events or activities for older people.

From the perspective of the theory of institutional ecology, intergenerational cultural programs can happen in those LTCIs facilities where the spatial layout of institution foresees a special auditorium for events to be held. Another crucial aspect that makes intergenerational cultural programs available for all older people to sufficient amount of staff members in LTCIs because some older people need assistance in order to take part in the event or activity. Shortage of helping aids also is limiting equal accessibility to intergenerational cultural programs for all older adults- LTCIs' residents.

The study shows that older people who are living in LTCIs settings are subject to everyday routine. LTCIs care provision is very much dependent on the authorities of the particular institution. The lack of interaction between older adults and the more active part of society prevents the finding of effective ways of achieving that the care in LTCIs is in accordance with the active ageing policy. 
According to the study results, the intergenerational cultural programs are mainly based on the initiative coming from volunteers and the enthusiasm of the event managers in LTCIs, and it shows that there are many unsolved issues within the institution in promoting intergenerational solidarity and organizing cultural programs. Finding a right solution to these issues is neither the social careers nor medical staff competency.

\section{Recommendations}

The study shows that it is important for an event manager to have a cultural capital and an experience in organizing events for older people residing in LTCIs. LTCIs management has limited resources to accommodate professional artists. It is one of the reasons, why a person appointed to manage cultural life in LTCIs has to have a cultural capital and personal contacts in a world of art. On the other hand, amateurs including various senior collectives, children from school, and students are very much willing to participate in intergenerational cultural programs in LTCIs because they are using it as a platform for an exposure and as an opportunity to perform in front of an auditorium. Volunteers are one of the ways, how some LTCIs are finding a solution to solve the problem of shortage of staff members.

Even though the amateurs give their performance free of charge in LTCIs, most of the times they require to accommodate them with transport for them to get to LTCIs. Transport availability in each of LTCIs differs because of the financial situation in each of LTCI. It is very different from all three kinds of LTCIs (state, local government and private). Better cooperation between state, local government, and private LTCIs could contribute to solving transportation problems. Authors suggest that specifically trained social workers equipped with additional resources would be suitable to take on to duties concerning intergenerational cultural programs including the organizing the transport for the participants.

In order to implement intergenerational cultural programs successfully in LTCIs, there are two ways of doing that. Firstly, state, and local government must include intergenerational cultural programs in their annual financial planning. Secondly, one could 
establish the special foundation for intergenerational cultural programs based on the contributions of public and private organizations, and private donations.

Concerning spatial layout for intergenerational cultural programs, not all LTCIs have suitable auditoriums for them to be held. As a solution for those LTCIs whose facilities are small for having older people to participate all at once in one room, the solution could be found by dividing them into smaller groups that can fit in one room and organize them cultural programs in a group setting. Another alternative for those LTCIs without any extra facility apart from rooms of their older residents, intergenerational cultural programs could be a seasonal solution as outdoor events organized in a back yard of LTCI.

\section{Acknowledgements}

This research has been generously supported by:

1. The SIforAGE project. SIforAGE consortium: Providing innovative solutions for an active and healthy ageing. Seventh Framework Program. European Commission. Link to the website: www.siforage.eu

2. The University of Latvia and The Advanced Social and Political Research Institute (ASPRI) was one of the partners in this research and were one of the 20 partners participating in this project. Link to the website: http://szf.lu.lv/eng/petnieciba/sppi-instituts/

3. The National Research Program SUSTINNO. Project No.2. Social Dimension of Sustainability and Social Innovation. Link to the website: https://dspace.lu.lv/dspace/handle/7/31767

\section{References}

Abrutyn, S. (2012). Toward A Theory of Institutional Ecology: The Dynamics of Macro Structural Space. Review of European Studies, 4(5), 167-180.

AGE Platform Europe. (2010). Intergenerational Solidarity the Way Forward: Proposals from the NGO Coalition for a 2012 European Year for Active Ageing and Intergenerational Solidarity. Retrieved from www.age- 
platform.eu/images/stories/EN/CoverAGE/EN/21879_brochure age_2010_en.pdf

Akkerman, S. F., \& Bakker, A. (2011). Boundary Crossing and Boundary Objects. Review of Educational Research, 81(2), 132169.

Alders, P., Comijs, H. C., \& Deeg, D. J. H. (2016). Changes in Admission to Long-Term Care Institutions in the Netherlands:

Comparing Two Cohorts Over the Period 1996-1999 and 20062009. European Journal of Ageing, 9(2), 1-9.

Amparo Cruz-Saco, M. (2010). Intergenerational Solidarity. In M. A. Cruz Saco \& S. B. Zelenev (Eds.), Intergenerational Solidarity. Strengthening Economic and Social Ties (1st ed., pp. 9-34).

New York, NY: Palgrave Macmillan.

BC Care Providers Association. (2009). Creating Caring

Communities: A Guide to Establishing Intergenerational Programs for Schools, Care Facilities and Community Groups. Retrieved from www.bccare.ca/wp-content/uploads/BCCPAIntergenerational-Toolkit.pdf

Bengtson, V. L. (1993). Is the "Contract Across Generations"

Changing? Effects of Population Aging on Obligations and Expectations Across Age Groups. In V. L. Bengtson \& W. A. Achenbaum (Eds.), The Changing Contract Across Generations (pp. 3-24). New York, NY: A. de Gruyter.

Bengtson, V. L., \& Oyama, P. S. (2007). Intergenerational Solidarity: Strengthening Economic and Social Ties: Background Paper.

Retrieved from

www.un.org/esa/socdev/unyin/documents/egm_unhq_oct07_ben gtson.pdf

Bērziņš, A. (2015). Sociālo pakalpojumu pieejamības un attīstības tendences Latvijā [Tendencies to access and development of social services in Latvia] [PowerPoint slides from conference] "Aprūpe mājās Latvijā - pieejamība, attīstība, izaicinājumi”" (Home Care in Latvia-Accessibility, Development, Challenges). Retrieved from www.samariesi.lv

Central Statistical Bureau of Latvia (CSB). (2015). Recipients of Pensions and State Social Maintenance Benefit at the End of the Year: Social Security: Key Indicators. Retrieved from www.csb.gov.lv/en/statistikas-temas/social-security-keyindicators-30686.html 
Central Statistical Bureau of Latvia (CSB). (2016). Resident

Population by Major Age Group at the Beginning of the Year.

Retrieved from

http://data.csb.gov.lv/pxweb/en/Sociala/Sociala_ikgad_iedz iedzskaits/?tablelist=true\&rxid=a79839fe-11ba-4ecd-8cc3$4035692 \mathrm{c} 5 \mathrm{fc} 8$

Cohen, G. D., Perlstein, S., Chapline, J., Kelly, J., Firth, K. M., \& Simmens, S. (2006). The Impact of Professionally Conducted Cultural Programs on the Physical Health Mental Health, and Social Functioning of Older Adults. The Gerontologist, 6(46), 726-734.

Cohen, S. S. (2007). 50 Essays: A Portable Anthology. Boston:

Bedford/St. Martin's.

Davidson S. R., \& Boals-Gilbert, B. (2010). What Age Gap? Building Intergenerational Relationships. Dimensions of Early Childhood, 2(38), 23-29.

European Commission. (2015a). Employment, Social Affairs \&

Inclusion Eurostat Demography Report. Retrieved from

http://ec.europa.eu/eurostat/documents/3217494/6917833/KE-

BM-15-003-EN-N.pdf/76dac490-9176-47bc-80d9-

029e1d967af6

European Commission. (2015b). The 2015 Ageing Report: Economic and Budgetary Projections for the 28 EU Member States (20132060). Retrieved from

http://ec.europa.eu/economy_finance/publications/european_eco nomy/2015/pdf/ee3_en.pdf

Featherstone, H. (2014). Cultural Participation by Older People: Are

We Aging Older in Life? Retrieved from

www.longlivearts.eu/upload/files/Helen\%20Featherstone.pdf

For the Wellbeing and Dignity of Older People (WeDO). (2012).

European Quality framework for long-term care services. WeDO

project 2010-2012. Retrieved from www.nhi.ie/doc.php?id=924

Generations United. (2006). Intergenerational Shared Sites:

Troubleshooting. Retrieved from

https://s3.amazonaws.com/pushbullet-uploads/ujzNDwQrsR2-

YYu8NQ8Cm2oNnfF30IdiOGIoMrzI6vxd/06-SharedSites-

Report-Troubleshooting.pdf

Generations United. (2007). The Benefits of Intergenerational

Programs. Retrieved from 
www.gu.org/LinkClick.aspx?fileticket=71wHEwUd0KA\%3D\&t abid $=157 \&$ mid $=6$

Kaplan, M., \& Sanchez, M. (2014). Intergenerational Programs and Policies in Ageing Societies. In S. Harper \& K. Hamblin (Eds.), International Handbook on Ageing and Public Policies (pp. 367-383). Cheltenham, UK, Northampton, MA: Edward Elgar Publishing.

Klimczuk, A. (2015). Economic Foundations for Creative Ageing Policy: Volume I: Context and Considerations. New York, NY: Palgrave Macmillan.

Latvijas Republikas Labklājības Ministrija (Welfare Ministry of Latvia). (2011). Eiropas gads aktīvai novecošanai un paaudžu solidaritātei [European Year for Active Ageing and Solidarity Between Generations]. Retrieved from www.lm.gov.lv/upload/eg2012/eg2012_progr_fin.pdf Latvijas Republikas Labklājības Ministrija (Welfare Ministry of Latvia). (2013). Sociālās aprūpes pakalpojumu ilgtspēju nodrošinās to balstǐšana sabiedrībā [LM: Social care services will ensure the sustainability of public reliance]. Retrieved from www.lm.gov.lv/news/id/4786

Lloyd, L., Tanner, D., Milne, A., Ray, M., Richards, S., Sullivan, M. P.,... Phillips, J. (2014). Look After Yourself: Active Ageing, Individual Responsibility and the Decline of Social Work with Older People in the UK. European Journal of Social Work, 17(3), 322-335.

Macionis, J. J., \& Plummer, K. (2008). Age Stratification, Children and Later Life. In J. J. Macionis \& K. Plummer (Eds.), Sociology: A Global Introduction (4th ed.) (pp. 402-427). Edinburgh Gate, UK: Pearson Education Limited.

Mather, M. (2007). The New Generation Gap. Washington, DC: Population Reference Bureau. Retrieved from www.prb.org/Publications/Articles/2007/NewGenerationGap.as px

Miller, B. K. (2002). Theories of Aging. In C. B. Lewis (Ed.), Aging. The Health-Care Challenge: An Interdisciplinary Approach to Assessment and Rehabilitative Management of the Elderly (4th ed., pp. 3-10). Philadelphia: F.A. Davis Co.

Newman, S., \& Hatton-Yeo, A. (2008). Intergenerational Learning and the Contributions of Older People. Ageing Horizons. (8), 
31-39. Retrieved from

http://riolis.ipleiria.pt/files/2011/03/Intergenerational-Learningand-the-Contributions-of-Older-People.pdf

OECD. (2011). OECD Ministerial Meeting on Social Policy. Session 3. Paying for the Past, Providing for the Future:

Intergenerational Solidarity. Retrieved from www.oecd.org/els/public-pensions/47711990.pdf

OECD. (2016). OECD Data. Elderly Population. Retrieved from https://data.oecd.org/pop/elderly-population.htm

Oliver, D., Foot, C., \& Humphries, R. (2014). Making Our Health and Care Systems for an Ageing Population. London, UK: The King's Fund. Retrieved from www.kingsfund.org.uk/sites/files/kf/field/field_publication_file/ making-health-care-systems-fit-ageing-population-oliver-foothumphries-mar14.pdf

Österle, A., \& Rothgang, H. (2010). Long-Term Care: Long-Term Care and the Welfare State. In F. G. Castles, S. Leibfried, J. Lewis, H. Obinger, \& C. Pierson (Eds.), The Oxford Handbook of the Welfare State (pp. 378-405). Oxford: Oxford University Press.

Parliament of the Republic of Latvia (Latvijas Republikas Saeima). (2002). Sociālo pakalpojumu un sociālās palīdzības likums [Law on social services and social assistance]. Retrieved from https://likumi.lv/doc.php?id=68488

Parliament of the Republic of Latvia (Latvijas Republikas Saeima). (2010). Apvienotās Nāciju Organizācijas Konvencijas "Par personu ar invaliditāti tiesībām" ratifikācijas īstenošanas gaita [Ratification of United Nations Convention on the Rights of Persons with Disabilities]. Retrieved from www.saeima.lv/en Piszczek, M. M., \& Berg, P. (2014). Expanding the Boundaries of Boundary Theory: Regulative Institutions and Work-family Role Management. Human Relations, 67(12), 1491-1512.

Republic of Slovenia Ministry of Labour, Family and Social Affairs. (2010). The Strategy of Care for the Elderly till 2010 Solidarity, Good Intergenerational Relations and Quality Ageing of the Population. Retrieved from www.mddsz.gov.si/fileadmin/mddsz.gov.si/pageuploads/dokum enti_pdf/strategija-_EN-starejsi.pdf 
Rezgale-Straidoma, E., \& Rasnača, L. (2015). Risks While Deinstitutionalizing Long-Term Elderly Care: The Case of Latvia. Socialiniai Tyrimai. (2), 82-92.

Rezgale-Straidoma, E., \& Rasnača, L. (2016). Long-Term Elderly Care Quality Assurance Challenges for Local Governments. Research for Rural Development. (2), 203-209. Retrieved from http://llufb.llu.lv/conference/Research-for-Rural-

Development/2016/LatviaResRuralDev_22nd_vol2-203-209.pdf Rollins, J. (2013). Bringing the Arts to Life. A Guide to the Arts and Long-Term Care. Retrieved from www.recreationtherapy.com/articles/BringingArtToLife.pdf

The World Bank. (2015). The Active Ageing: Challenge for Longer Working Lives in Latvia. Retrieved from http://pubdocs.worldbank.org/pubdocs/publicdoc/2015/9/205791 443642635843/WB-Latvia-Active-Aging-Report.pdf

Toepoe, V. (2011). Cultural Participation of Older Adults: Investigating the Contribution of Lowbrow and Highbrow Activities to Social Integration and Satisfaction with Life. International Journal on Disability and Human Development, 2(10), 123-129. Retrieved from

www.lissdata.nl/dataarchive/hosted files/download/1072Cached Tymowski, J. (2015). European Year for Active Ageing and

Solidarity between Generations (2012) European

Implementation Assessment: European Parliamentary Research Service. Retrieved from www.europarl.europa.eu/RegData/etudes/IDAN/2015/536344/E PRS_IDA(2015)536344_EN.pdf

United Nations. (2006). Convention on the Rights of Persons with Disabilities. Geneva. Retrieved from www.un.org/esa/socdev/enable/rights/convtexte.htm World Health Organization (WHO). (2002). Active Ageing: A Policy Framework. Geneva. Retrieved from http://apps.who.int/iris/bitstream/10665/67215/1/WHO_NMH_ NPH_02.8.pdf

World Health Organization (WHO). (2011). Global Health and Ageing. Retrieved from www.who.int/ageing/publications/global_health/en/ World Health Organization (WHO). (2016). Global Strategy and Action Plan on Ageing and Health (2016-2020): A Framework 
for Coordinated Global Action by the World Health

Organization, Member States, and Partners Across the Sustainable Development Goals. Retrieved from

http://who.int/ageing/GSAP-Summary-EN.pdf?ua=1 

Suggested Citation: Sariipek, D. B., \& Çuhadar, S. G. (2017). Implementation of a "Self-Sufficient Ageing" Policy and Possible Challenges: Case of Turkey. In $Ł$. Tomczyk \& A. Klimczuk (Eds.), Selected Contemporary Challenges of Ageing Policy (221-256). Kraków: Uniwersytet Pedagogiczny w Krakowie. Doi:

\title{
DOGA BASAR SARIIPEK ${ }^{1}$
}

\section{SEYRAN GÜRSOY ÇUHADAR ${ }^{2}$}

\section{Implementation of a "Self-Sufficient Ageing" Policy and Possible Challenges: Case of Turkey}

\begin{abstract}
The policies of socioeconomic protection of older adults in most parts of the world are being redesigned in the scope of value-added targets, such as active ageing, successful ageing, or creative ageing. The main purpose here is, of course, enabling older adults self-sufficient and beneficial both for themselves and their social environment, instead of being simply the passive beneficiaries of the public support mechanisms. Turkey has a population which is still young but ageing very rapidly and will reach to the same point as Europe today in a relatively much shorter time. However, the country still seems to be away from conducting systematic and holistic measures, except for a few ineffective strategy papers and legal regulations. Therefore, Turkey must immediately design a new policy agenda in conformity with its traditional and historical advantages. Revitalizing the intergenerational solidarity bonds, in this regard, may be the best cost-effective solution to complement formal measures in the provision of social protection and in the process of
\end{abstract}

\footnotetext{
${ }^{1}$ Doga Basar Sariipek, Kocaeli University, Turkey, sariipek@kocaeli.edu.tr.

${ }^{2}$ Seyran Gürsoy Çuhadar, Kocaeli University, Turkey, seyrangursoy@gmail.com.
} 
active ageing. However, this traditional protection net is under attack of increasingly transforming socioeconomic conditions. Consequently, as one of the most rapidly ageing countries in the world, Turkey should immediately stimulate studies and debates over a healthy, functional, and effective ageing period and caring issues. Otherwise, governments will be blindsided by the socioeconomic, psychological, cultural, and physiological problems related to the ageing process. In the light of these facts, the main purpose of this study is to discuss policy recommendations to create a self-sufficient ageing period for older adults in the context of Turkish case.

Key words: Ageing, Third Age, Fourth Age, Older Persons Care, Turkey, Informal Care

\section{Introduction}

The issue of population ageing, which can be defined as the increase in the number of older adults in the society, is doubtlessly one of the most remarkable demographic issues of the twenty-first century. A much more important point is the fact that this process will continue to maintain its importance during the rest of the century. According to the projections on this matter, the population of older adults over 60 is estimated reach to 1.2 billion by the year 2025; 1.3 billion by 2040 and 2 billion by 2050 . Furthermore, it is also predicted that older adults over 85 in the "fourth age" group will outnumber six times more the ones over 65 in the "third age" group at the end of the first half of the 2000 s (TYDYUEP, 2013, p. 4).

At first, the issue of population ageing was only a problem for developed countries. However, it has recently been observed in many developing countries, too. Moreover, in the very near future, it is certain that almost all countries will face the problem of population ageing at different periods of time, at different density and pace.

Behind this claim, there are some factors such as the decline in the birth-rate, improvements in the nutrition, and developments in the healthcare and technology and as a result of these, people started to have a lot longer lifespan. In this context, for instance, 
the longevity extended 20 years more in Europe between the years 1900 and 1950. It is expected that this will be added ten years more in 2050 (SPO, 2007, p. 6). The data from the World Health Organization shows that the rate of older adults in Europe will reach $25 \%$ of the whole population in 2050 (WHO, 2016).

Population ageing is not merely a demographic transformation, and it means a series of a burden on the society. Ageing is not only an inevitable physical process, but it also leads to a lot of relevant results on community health care and socioeconomic and cultural structure. In this sense, there becomes a pressure on the labor force and finance market; a vast increase in the demands on goods and services such as accommodation, transportation, and social protection; so, it is inevitable that the family structure and the connection between generations will be affected negatively. In fact, together with the increase in ageing, significant concerns have aroused on the sustainability of the social support systems and solidarity among generations, which are directly effective on the level of welfare of both young and old generations. These concerns have risen since the number of traditional large families decreased and the number of nuclear families increased. Women who traditionally used to be responsible for caring the family have joined the labor market more. This has also increased concerns, too.

Therefore, it is crucial to be able to foresee the economic and social transformations related to ageing. This is important for the countries' development process. That is why, it is necessary to have a holistic and multi-branch political package empowered with perspectives such as social security, healthcare, environment, education, socio-cultural activities, and family life. As the population of the countries ages, it becomes critical for the governments to design public services and innovative policies in the fields of healthcare, employment, accommodation, and social security directly for older adults.

When we look at the issue of population ageing regarding Turkey, it is understood that Turkey has similar features to other developing countries. However, it is also observed to have distinctive features, too. The total population in Turkey is approximately 77 million, and there are about 6.5 million older 
adults over 65 , and this is $8.2 \%$ of the population. Even though Turkey statistically seems to be a young country, it is, in fact, a state that is getting older very fast. As a matter of fact, it is calculated that the rate of older adults which was $5.7 \%$ in 2005 will have risen to $17.6 \%$ by 2050 . Therefore, ageing is a significant problem for Turkey, which has to be seriously taken into consideration and urgent precautions have to be taken. Because the population grows fast, the need for care for older adults grows at the same speed, too. As a result, there will be significant pressure on the society in the very near future, especially in the social security services. Therefore, the governments of Turkey need to see this challenge that is approaching very fast, and it needs to take necessary institutive, humane, and legal precautions urgently.

However, in Turkey, no systematic and rights-based policy for the care for older adults has been applied up to date. One of the most important reasons of these is doubtlessly the fact that Turkey was a country with a young population in the majority of the twentieth century. In addition, almost all needs of older adults have been traditionally met with the solidarity among family members and support systems so far. This informal solidarity and caring system have relieved the governments, and this has led to a delay of the systematic precautions to be taken for the care for older adults for extended years. In recent years, the older population has increased, and the family structure has changed; together with that, there have been a lot of demographic changes. All these things have caused a failure in informal support network. For this reason, the state ought to develop a new approach to care for older adults. Nevertheless, when we look at the development plans for the last 50 years and governmental projects, it can be concluded that the government is not aware of the ageing problem. It is understood that the government still approaches to this issue with traditional methods and mechanisms. This means that the state in Turkey uses old solutions of the twentieth century for a problem of the twenty-first century. 


\section{The Phenomenon of Ageing}

Ageing is a phenomenon dealt with various aspects. Therefore, many different definitions are found in the literature. Even though it is mostly emphasized in these notions that ageing is a biological, chronological, and physiological process, there have been different approaches to ageing in recent periods such as active ageing, successful ageing, and ageing in place. At the same time, there are definitions that consider the ageing phenomenon as an age discrimination such as "although the mental capacity is kept, the energy and coherence skill decrease, hence the ability to perform work is lost" (Büken, 2010, p. 33). These definitions have correlated ageing with the loss of abilities. If we need to make a general evaluation of these definitions, it can be understood that biological ageing is restricted with "anatomical and physiological functional changes, yet chronological ageing is defined by considering one-year units in time" (Güler, 1998, p. 105). Physiological ageing is when the person feels old, and he accepts himself as old. It is defined as the changes emerged from the decrease in mental skills, mental functions, and behavioral compatibility (Hablemitoğlu and Özmete, 2010, p. 19). Another type of ageing is social ageing which means that the person loses strength and stays away from his work and social life (Öztürk, 2015, p. 7).

Besides these classical approaches to ageing, some new approaches that are appropriate for social, economic, and even political transformations have emerged in recent periods. The first of these is the active ageing concept, and it is defined as the process of promoting the health, participation and caregiving institutions for older adults to raise the quality of their lives as they get older (WHO, 2002b). Another approach for older adults is successful ageing, which was defined long before the notion of active ageing and which is, in fact, a more detailed approach covering the active ageing process, too. In other words, a successful ageing concept is a multi-dimensional approach that covers not having a disease, maintaining functional capacity, and participating life in an active way (Özmete, 2012, p. 2).

All these definitions explain ageing with a minimum one dimension. However, there is not an agreed definition about at 
what age a person should be called "old." According to the World Population Ageing Report, which was released by the United Nations Statistics Unit in 2013, one of the contemporary sources about this issue; the population aged 60 and over is accepted to be an older person unless a different explanation is made (UN, 2013, p. 3). At the same time, the World Health Organization accepts the age 65 as "chronologically old" in the majority of developed countries, yet this definition is not enough for under-developed countries (WHO, 2002a).

However, the average life expectation is getting longer, and the population of the 65 and over is increasing rapidly. As a result, the older population is divided into sub-groups, and the policy to be applied should be determined according to this division. In fact, the process of ageing and the requirements emerged from this differs for both the individuals and the age groups. In this concept, the start of the older age period can be different for every person in connection with primary ageing with chronologically getting older. On the other hand, it can also be different for every individual with different lifestyles and social pressures determined by emotional disturbance, illnesses, malnutrition and unhealthy diet, and stressful lifestyles (Hablemitoğlu and Özmete, 2010, p. 19).

The third and the fourth age concepts, which have been used more often in recent periods, are in fact a reflection of this situation. According to this, it is expressed that life will be divided into more than one ageing period (Laslett, 1991) and in today's world, concepts of third age and fourth age have often been used similarly to previously used classifications such as "young-old" and "old-old"3 (Neugarten, 1974).

\section{Third and Fourth Age: A Conceptual Frame}

The world population has been ageing rapidly especially in the developed countries. Moreover, this affects the societies socially,

\footnotetext{
${ }^{3}$ For the definition of the WHO, please check "A Glossary of Terms for Community Health Care and Services for Older Persons," www.who.int/kobe_centre/ageing/ahp_vol5_glossary.pdf?ua=1.
} 
economically, politically, and even culturally. As a result, new policies need to be applied. However, societies do not get older homogeneously. This means that there is discrimination in the ageing period when different age groups are getting older at a different speed and diverse ways, and they have different needs and demands. The third age and the fourth age classification may be interpreted as the result of discrimination.

In this frame, while the third age is defined as "the period of amenities" because of the opportunities it offers, the fourth age is defined as the "period of threats" because of the problems and threats it holds. The Figure 1 and Figure 2 below illustrate the different formation process of the third and fourth age periods in Turkey.

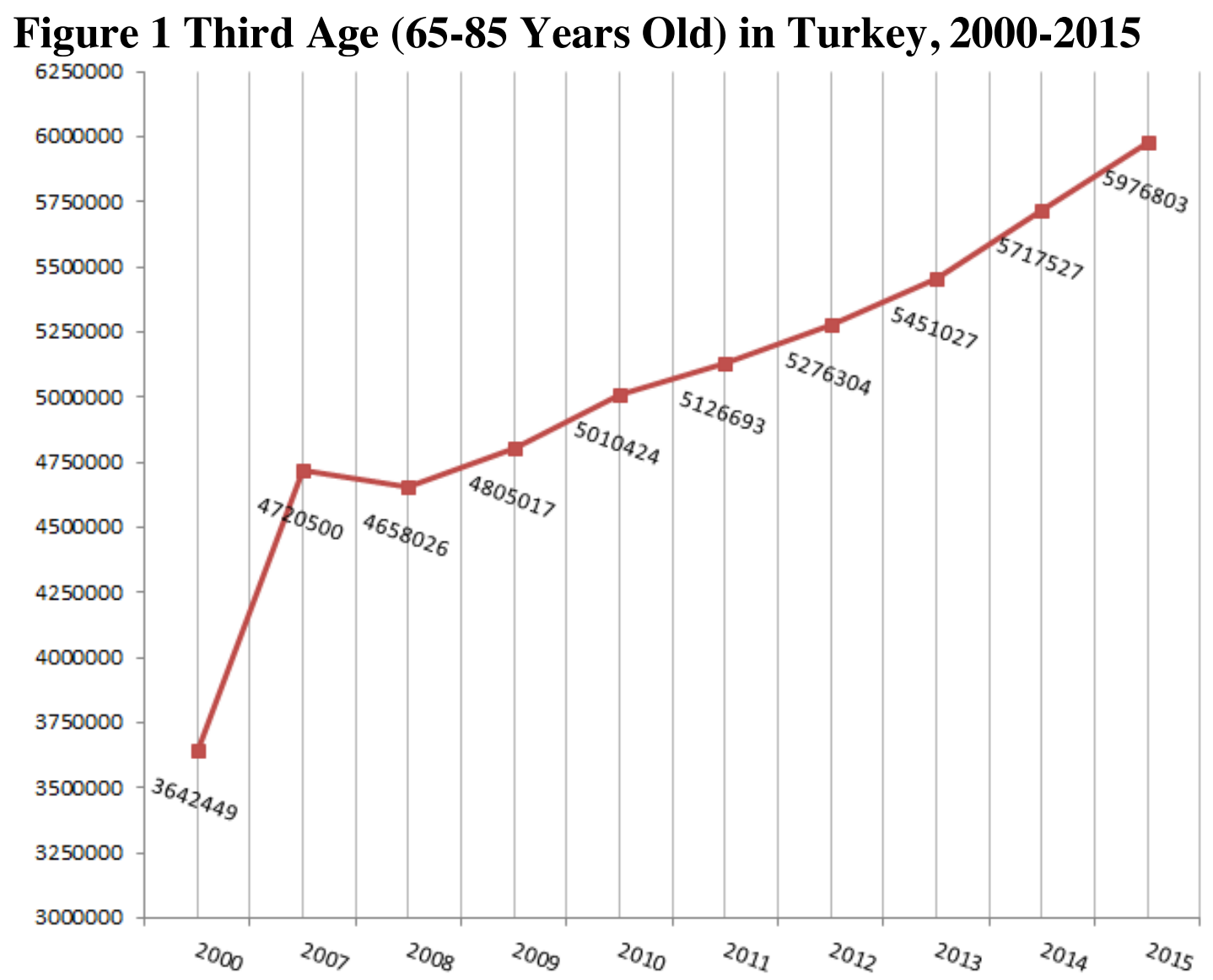

Source: Compiled from TurkStat datasets by authors.

Defining the subgroups of older age population is an attempt to illustrate that older age population has heterogeneous 
characteristics regarding social participation, death rate, and the need for social care; thus, all these demands differ for each older adult. In this context, it will be useful to divide older adults into "the third age" and "the fourth age" groups for designing a future to old age population. All in all, it is observed that the third and the fourth age are defined in two ways. The first is the populationbased definition, and the latter is individual-based definition. Both definitions are extremely necessary and useful to comprehend the idea in different concepts, and to give way to evaluations and interpretations of various ages and that they are different.

\section{Figure 2 Fourth Age (85+ Years Old) in Turkey, 2000-2015}

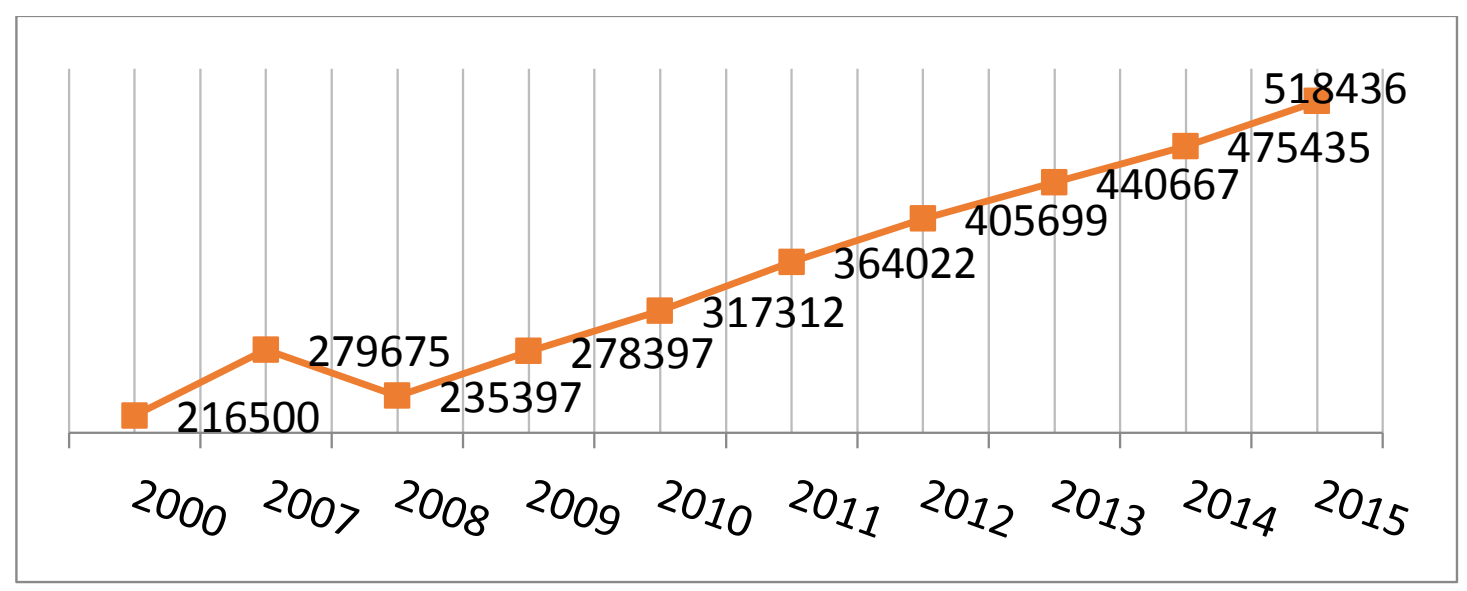

Source: Compiled from TurkStat datasets by authors.

According to the population-based definition, the transition from the third age to the fourth age starts when at least $50 \%$ of the ones born at the same time or in the same year are not alive. Such criteria increase the possibility of the fact that those individuals at later periods of this age are in real ageing process. According to this definition, the transition from the third age to the fourth age starts in their 75 or 80 s in developed countries (Olshansky, Carnes and Désesquelles, 2001, p. 1491; Vaupel et al., 1998, p. 857; Kannisto, 1996). In developing countries, however, this transition starts at earlier ages; it differs in a larger scale from 55 to 70 , depending on the fertility rate and the average lifespan.

The real aim at the individual-based definition is observed to predict the maximum lifespan of the individual rather than 
predicting the average life expectancy of the population. A person can be expected to live maximum 80 or 120 years in today's conditions if we exclude some specific diseases that prevent a person to have a longer life. According to this, the transition for the individual from the third age to the fourth age can start at the age of 60 whereas it starts at the age of 90s for others (Finch, 1996, p. 494; Manton, 2001, p. 307).

This third and fourth age discrimination can be evaluated as a contribution to the explanations under different names done before. Long ago, Neugarten claimed (1974) that old age was not only one period in a lifetime, on the contrary, but it must also be divided into different sub-groups, and he did this division as "young older adults" and "old older adults." However, the most remarkable claims on this issue belong to Peter Laslett (1991). Laslett is considered to be the first who argued that life could be divided into many old age periods. His claim is based on underlining the originality and uniqueness of the third age period.

However, the determination of "which older adults belong to which age group?" is the question whose answer remains unclear. It will be better to talk about common approaches rather than precise determinations on this matter. In this context, the beginning of the third age period is accepted when the person quits his active and productive work life and gets retired (Smith, 2000, p. 4; Guidance for the Elderly, 2016). It is the last part of the third age period or the beginning of the fourth age period when ones start to have physical, emotional, and mental limitations related to his or her age. Therefore, the third age is usually between approximately 65 and 80 (or 85) in today's world (Barnes 2011, p. $1)$.

The third age is a concept which is considered to be a period where a healthy life is highly expected and which is believed to have risen the living standards of the retired people in their later life (Laslett, 1991). Moreover, it is defined as the "golden era" of the adulthood by many researchers (Barnes, 2011, p. 1). The contribution by Laslett to the argument is that new conditions of this later life can be formed with personal interests and expressing themselves when the formal employment period is over, and necessary family responsibilities have been completed. In this 
frame, new definitions and concepts about ageing have been suggested such as "usual and successful ageing" (Rowe and Kahn, 1987) and "productive ageing" (Weiss and Bass 2002, p. 5).

As clearly seen in Table 1, it can be observed that the group aged 85 and over, that is the fourth age group, is increasing a lot faster than the whole of the old age population in Turkey. In other words, it is, of course, understood that the fastest-growing group of older adults is the fourth age group (SPO, 2007, p. 5). There is, in fact, conformity between this data and the future predictions about ageing in the world. According to this, it is estimated that the number of older adults in the fourth age group will be tripled to 434 million by the year 2050, which was 125 million in the year 2015 (UNFPA, 2015, p. 2). This rapid increase in the old age population has clearly been emphasized in other global reports, and there have been warnings. For instance, according to the World Health Organization, the number of older adults in the fourth group will be six times higher than those in the third group at the end of the first half of the 2000s (WHO, 2002b).

Table 1 The Increase Rate of the Third and Fourth Age Groups in Turkey, 2000-2015

\begin{tabular}{|r|r|r|r|r|}
\hline & $65-85$ & $85+$ & 3. age rate & 4. age rate \\
\hline 2000 & 3642449 & 216500 & $\mathbf{0 , 0 5 3 7}$ & $\mathbf{0 , 0 0 3 1 9}$ \\
\hline 2007 & 4720500 & 279675 & $\mathbf{0 , 0 6 6 9}$ & $\mathbf{0 , 0 0 3 9 6}$ \\
\hline 2008 & 4658026 & 235397 & $\mathbf{0 , 0 6 5 1}$ & $\mathbf{0 , 0 0 3 2 9}$ \\
\hline 2009 & 4805017 & 278397 & $\mathbf{0 , 0 6 6 2}$ & $\mathbf{0 , 0 0 3 8}$ \\
\hline 2010 & 5010424 & 317312 & $\mathbf{0 , 0 6 8}$ & $\mathbf{0 , 0 0 4 3}$ \\
\hline 2011 & 5126693 & 364022 & $\mathbf{0 , 0 6 8 6}$ & $\mathbf{0 , 0 0 4 9}$ \\
\hline 2012 & 5276304 & 405699 & $\mathbf{0 , 0 6 9 8}$ & $\mathbf{0 , 0 0 5 4}$ \\
\hline 2013 & 5451027 & 440667 & $\mathbf{0 , 0 7 1}$ & $\mathbf{0 , 0 0 5 7}$ \\
\hline 2014 & 5717527 & 475435 & $\mathbf{0 , 0 7 3 6}$ & $\mathbf{0 , 0 0 6 1}$ \\
\hline 2015 & 5976803 & 518436 & $\mathbf{0 , 0 7 5 9}$ & $\mathbf{0 , 0 0 6 6}$ \\
\hline
\end{tabular}

Source: Compiled and calculated from TurkStat datasets by authors.

Under these conditions, social service and assistance programs for older adults need to be designed separately for each 
age group. Because it is possible for a society to have a successful and productive ageing period and the possible adverse effects of this process on the economical, social, and political structure and especially on social security systems can be removed only when different ageing policies are designed for different sub-groups. Exactly at this point, Turkey seems to be unsuccessful. Because even though Turkey is still in the last phase of the demographic window of opportunities, it grows old much faster than similar countries and it is observed that political decision-makers in Turkey does not seem to have realized this. In addition, no separation in ageing policies has been done yet. Therefore, the issue of the fourth age period, in which we will face a serious challenge in a very near future, is still dealt with the third age perspective.

\section{The Theory of Demographic Transformation and the Situation in Turkey}

The theory of demographic transformation predicts a transition from a period when nations had high birth rates and low death rates to a new period where death rates decrease, and birth rates are deliberately controlled (Özbay, 2015, pp. 254-255; Yüceşahin, 2011 , p. 11). The demographic transformation consists of three stages, and at the first stage, pre-industrialization stage, both the birth rates and the death rates are high; and the rate of increase in population is at the minimum level. At the second stage of the transformation, the mortality rates start to go down because health and life conditions have improved as a result of industrial revolution and this is followed by a decrease in the birth rates. Therefore, rapid growth in population is observed at this stage. At the third and final stage of the transformation, the increase in population is at the minimum level just like at the first stage, and the birth and death rates go down to a very low level. According to this theory, all societies will inevitably go from a stage where the fertility and death rates are very high to another stage where both rates are lower (Teitelbaum, 1975, p. 421; Kinsella and He, 2009, p. 20).

The theorists claim that every country will experience the same demographic evolution but at different times because of the 
modernization, industrialization and urbanization. According to this, the demographic transition will be observed firstly in Europe and North America, later in Asia and Latin America and finally in sub-Saharan African countries (Lee, 2003, p. 172).

\section{Figure 3 Population Pyramid}

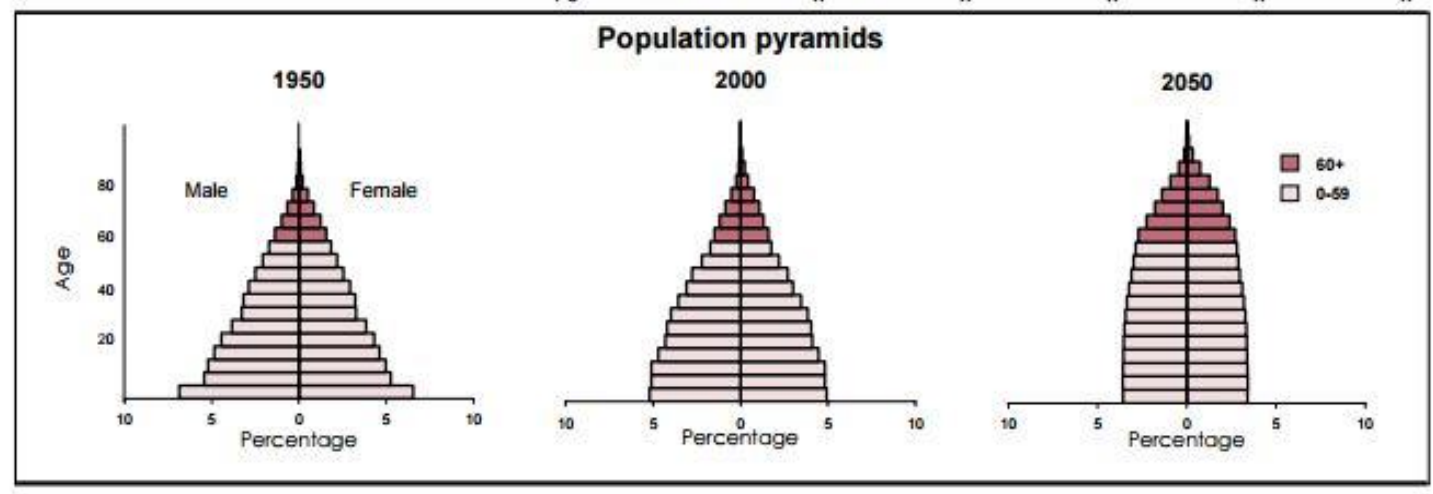

Source: UN, World Population Ageing 1950-2050.

The Figure 3, which belongs to the United Nations, shows the global population pyramid including the years 1950, 2000 and 2050 and it seems to prove the theory of demographic transformation. As understood from the graph that the population of those under the age of 20 covers a vast scale compared to those over the age of 60 in the year 1950 and that is because the shape looks similar to a pyramid. However, when we look at the figures of the year 2050, the shape of the graph looks similar to a column rather than a pyramid, which is a characteristic of the age pyramid of the developed countries. It is predicted that while there is a decrease in young age population, there will be an increase in old age population.

When the situation in Turkey is examined, the population structure was understood to have been designed through various population policies since the Proclamation of the Republic. In this context, the history of the population policy consists of three periods. The first period is called "pro-natalist" between the years 1923 and 1955. The second is a period of the years 1955 and 1980 when the "anti-natalist" policy was dominant. The final period is after the year 1980 when the anti-natalist policy was settled (Koç et al., 2010, p. 48). 
If it is necessary to make a general evaluation that covers all these periods, we have signs that show continuous improvements in socio-economic areas especially in mother and child healthcare; this has resulted in dramatic decreases in deaths of children under the age of 5 and the number of births-per-woman. So, Turkey has gone through the final stage that was mentioned in Turkey's demographic transformation theory. That means Turkey is no longer a young country which used to have high birth and death rates; it has become an ageing country which has lower birth and death rates (Koç et al., 2010, p. 4). On the other hand, when it is compared to European countries, it is observed that the population rate of older adults aged 65 and over is not as high. However, the problem in Turkey that must remarkably be underlined is the speed of ageing.

If it is necessary to express directly, Turkey is getting older a lot faster than the countries in a similar situation. For example, as seen in Table 2, old age population in France needs to take 115 years to go up from $7 \%$ to $14 \%$ whereas only 21 years will be enough for the same increase rate in Brazil. A similar difference in ageing speed is a pic for discussion for Turkey and the whole of Europe. It is predicted that Turkey will take 27 years to reach the ageing period when it is almost 100 years in Europe. The United Nations Projections show that in Turkey, the population over the age of 60 , which was $11.2 \%$ in 2015 , will be $17 \%$ in 2030 with a $5.9 \%$ increase rate, and it will reach $26,6 \%$ in 2050 (UN, 2015, p. 147).

This situation shows that the demographic transformation period will take a shorter time in the countries such as Turkey, where this process has been delayed (TUSIAD, 1999, p. 6; Koç et al., 2010, p. 5). It can clearly be seen in the Population Report prepared by Kinsella and He (2009). According to this report, old age population in the world is densified in industrialized areas of the North America and Europe, the rate of the old age population in developing countries is much more rapidly than those in developed countries.

Table 2 Ageing Speed in Turkey and Some Other Countries* 


\begin{tabular}{|c|l|c|c|c|}
\hline \multicolumn{2}{|c|}{ Countries } & $\begin{array}{c}\text { The year } \\
\text { reaching } \\
\text { \%7 of the } \\
\text { general } \\
\text { population }\end{array}$ & $\begin{array}{c}\text { The year } \\
\text { reaching } \\
\text { \%14 of the } \\
\text { general } \\
\text { population }\end{array}$ & $\begin{array}{c}\text { Transition } \\
\text { period } \\
\text { (year) of } \\
\text { the general } \\
\text { population }\end{array}$ \\
\hline \multirow{3}{*}{$\begin{array}{c}\text { Developed } \\
\text { Countries }\end{array}$} & France & 1865 & 1980 & 115 \\
& Sweden & 1890 & 1975 & 85 \\
& USA & 1945 & 2013 & 69 \\
Developing & England & 1930 & 1975 & 45 \\
Countries & Azerbaijan & 2004 & 2037 & 33 \\
& Brazil & 2011 & 2032 & 21 \\
& South Korea & 2000 & 2018 & 19 \\
& Turkey** & 2012 & 2039 & 27 \\
\hline
\end{tabular}

*The transition time of the population of $0-65$ and over from $7 \%$ to $14 \%$ in Turkey

**Turkey, calculated from the data of TurkStat.

Source: Kinsella and Gist (1995).

When compared to European countries, it is understood that Turkey is getting older nearly twice faster than other countries. It was also understood that this situation caused Turkey to be found unprepared about the social politics for older adults (Danış, 2014). Therefore, both a radical social politics package and a new population politics are necessary to produce remedies for these problems.

\section{Care for Older Adults in Turkey and the Level of Socio- Economic Security}

Numerous universal declarations have confirmed that the issue of care for older adults cannot be left to the mercy of informal solidarity; a legal and rights-based formal caring system must be founded. For example, the 25th Article of Universal Declaration of Human Rights includes the right to social security for older adults. Also, the World Health Organization has obvious focuses and targets directly for older persons and seniors care. Besides these, First and Second Older Adults Assemblies have been organized to emphasize the importance of older adults issue, and it has been 
tried to draw the public attention to how a respected ageing can be provided.

Even though the formal side of older persons' care is emphasized in those universal texts and assemblies, informal relation networks are not totally excluded. For example, in 1994, the issue of ageing was specifically mentioned in the International Conference on Population and Development in Cairo. During this conference, some targets were set to provide family members with a necessary support system to look after an older family member, and targets to create basic healthcare for older adults and to form economic and social security systems. In other words, it was argued at the conference that informal networks have to be designed to work on the right and effective ways; and it should be designed in the way that there is a successful coordination between the formal and informal networks. It was predicted that older adults could be a good source for the development of the country only when it is done in that way.

As in every country, in Turkey, too, formal, and informal support networks have been applied intensely. Under normal conditions, these two sources should complete one another instead of replacing each other. However, it is not easy to say that there has been a balanced relation between these two. On the contrary, there is a reversal, opposite relation between them. Family and kinship solidarity in Turkey, other inter-individual and relational networks such as neighborhood or citizenship and some informal and voluntary mechanisms such as non-governmental organizations, have always been traditionally powerful and governmental organizations, which are the formal part of the care for older adults, have been the complementary part of it. In short, the idea that older persons' care is an issue which must be solved inside the family dominates the social politics of the state. For instance, "The Action Plan for Ageing," which was released in 2013, clearly included the statement: "the feelings of love and mercy, rooted in Turkish culture, have put the rights of older adults on the focus of families." Other documents and explanations, which reveal the tendency of the state and the governments to leave older persons' care to the informal and 
voluntary networks, will be examined in a detailed way at the end of this study.

\section{Informal Care for Older People in Turkey}

In the pre-capitalist countries, while the family met all the physiological, physiological, and sociological needs of the individuals, it socially had the characteristics of being the unique and independent structure that helps to recreate the society (Özbay, 2015, p. 32). In these periods, when the large and patriarchal family structure was dominant, the family used to take direct responsibility for the care for older adults besides other social protection responsibilities. This caring system by the family was fed with some ideological basis such as religious and cultural values, and it became the only source to provide care for older adults. These characteristics of the families have relieved the governments by saving them from the trouble of the expenses for starting a systematic and rights-based care system for older adults (Özbay, 2015, p. 59).

The family structure in the pre-capitalist period is extremely coherent with the structure of the population. In these societies, the population increased at a very slow speed yet still there were high fertility and death rates (Özbay, 2015, p. 51). When we look at the situation in Turkey, it is understood that all these characteristics were observed especially before the year 1950 . The serious decline in the number of male adults was observed because of the significant losses during the war (Shorter, 1985). Also, it was also known that many Greek families had immigrated to Greece during the War of Independence (Keyder, 1982). All these events have created negative pressures on the re-creation capacity of the society.

Even though Turkey has many typical characteristics of societies in pre-capitalism, it also shows distinctive features at some points, too. In a clearer expression, despite the fact that the traditional family and kinship relations had been strong for hundreds of years, it will not be true to describe Turkey as an individualist or communitarian country. There are many reasons of this. That is why it will be better to describe Turkey's human development model as "interdependence model." Communitarian 
and individualist tendencies can be found in a special synthesis and balance in this model. In such a society, families have the leading roles in meeting the needs of older adults. The number of older adults who never get any caring support from their families is rather low. A relatively negative part of this situation is that families can sometimes be unwilling to search and accept the institutional aid and support programs prepared for older adults (Imamoglu, 1987). This unavoidably decreases the possibility of the concept of a rights-based concept to settle in this area.

The care for older persons is still a problem that must be solved inside the family because of insufficient development of formal care system in Turkey, and it directly depends on the good faith of the families. According to a traditional family structure, care for older adults is the spouse's responsibility in the first place. However, if the spouse is similarly old and cannot look after her husband or wife, this responsibility passes to the children.

Thanks to the extremely strong and traditional family ties in Turkey, most of older adults still live with their children in the same flat, building or the same neighborhood, and they lead their lives under their protection, observation, and close interest. According to a survey that was performed by the State Planning Organization, seven out of every ten older adults live with their children in the same house and building or neighborhood (SPO, 2007, p. 11). This enables the family to support older adults both socially and economically, and it helps the state's responsibility to provide social protection.

However, a series of pioneer improvements in recent periods, such as industrialization, urbanization, and capitalization, led the family to lose this characteristic. Some reasons, such as the start of agricultural modernization in the first years of the 1950s, the rapid decrease in the death rates, the concealed unemployment caused by a continuous rise in the population, and the shortage of fertile lands, started the migration from rural areas to urban areas. This changed the urban and rural population distribution (Özbay, 2015 , pp. 84-85). When it comes to 1968 , the rate of patriarchal families consisted of nearly one-fifth of all families (Özbay, 2015, p. 86). All these changes especially socioeconomic ones changed 
the basic function of the family and similarly, the attitude towards older adults differed.

This situation is a more visible problem especially in metropoles where social life passes a lot faster. In the end, the status of older adults and their functions in the society, social foundations, attitudes, and values seriously change because of the processes mentioned before. As a result, some demands to replace the informal care services that fall behind with formal care services are getting more and more day by day.

On the other hand, demographic transformations have been as effective as the changes discussed above in the change of interindividual relations. In addition to individuals' living longer, the increase in the divorce rate and the number of single parents; the return from the traditional family structure to nuclear families and the women starting to be active in working life have weakened the strong position of older adults inside the family that they used to have before and this case has threatened the informal support mechanisms (Akgeyik, 2006, p. 59; Bayoğlu, 2011, p. 125). Furthermore, children's immigration from the country to the city, the increase in cultural conflicts between the old and the young, and social and economic deprivation have all weakened the strong positions of older adults (Saka and Varol, 2007, p. 209). Despite all these things, however, several studies are showing that older adults still prefer to be looked after in a traditional way inside the family rather than in institutional care (Karahan and Güven, 2002).

Thus, the rate of the nuclear families in Turkey is extremely high, $87 \%$, while the large family rate is only $12.3 \%$ (AITFS, 2014 , p. 29). The functional existence of the large family and relationships with family members is still kept. That is, even if the family members live in different houses, the solidarity among them continues. That is why; it is more common in Turkey to care older adults both financially and physically by the family when it is compared to other Western societies (SPO, 2007, p. 103; Cankurtaran and Eker, 2007, p. 66). Furthermore, older adults, too, try to have this large family structure.

In fact, even if the majority of older population experience neglect or abuse, they may prefer to stay quiet because of the social pressure to be condemned or pointed at. In addition, there is 
always a risk of being taken out of the house and be sent to the nursing home. This situation is still considered as a shame in Turkey for older adults whose children are still alive.

\section{Formal Care for Older Adults}

Formal care for older adults in Turkey has always been weak and insufficient in contrast to the informal ones. As a matter of fact, the regulation concerning the care for older adults consists of only a few weak strategy documents and a few articles in law. Moreover, a strong and developed institutionalization has not been achieved yet. The insufficiency in these applications can be explained with traditionally strong and effective informal applications to a point. More clearly, a lot of social protection services, which must normally be done by the state as the rightsbased entitlement, have been carried out with informal and voluntary branches such as the family, relatives, and charities. As a result, the state has a seconder and complement role. That means the governments have benefited from the informal and voluntary sectors as they decrease the expenses of older persons' care.

As in many other countries, in Turkey, too, the formal protection system of older adults is a social security system as it was stated in the 1982 Constitution. Older people need to have worked and made a payment of premium for a period of time if they want to be included in the social security scheme. Not only the social security system provides regular income for older adults every month both in the active work period and retirement period, but it also offers a health service for older adults and those under their responsibility.

When we look at the insufficient regulations for older persons' care in a chronological way, the first thing that we see is the one in 1930, 1580 Article in Municipalities Law. This law says that the responsibility for the protection of older adults who need care is given to the municipalities. Apart from this, the General Directorate of Social Services was founded referring to the Ministry of Health and Social Aid Organic Law, 3017, in 1963 with the Law Article 17. Therefore, it became possible to give holistic care services compatible with human dignity rather than irregular and unplanned in-kind and in-cash services by public and 
private foundations. The first nursing home was opened in 1966 under the General Directorate of Social Services. It can be noticed that this is a highly late precaution that was put into effect and older persons' care has been left to the family-based informal networks for long years.

This weak legal frame has emerged even though it is an issue mentioned in the Constitution, too. The Article 61 of the Constitution of 1982 has stated that children, older adults, and the people with disabilities who need to be protected, cared, and rehabilitated will have the priority and the state is responsible for funding or building necessary foundations. There is also law enforcement in the same Article concerning older adults: "the state protects older adults. Law regulates the aid to older adults by the state and other rights." In this context, Law on Social Services and Child Protection Institution was introduced with law number 2828 (SHÇEK). The 9th Article of this legislation and part $b$ defined that it is the duty of the General Ministry of Family and Social Politics to determine, protect, care, and rehabilitate children, older adults and people with disabilities that need to be protected, cared, and rehabilitated. In 2011, Directorate General of Services for Persons with Disabilities and Older Adults was founded under the General Ministry of Family and Social Politics. Thus, all the services for older adults are provided by nursing homes, older adults care houses and rehabilitation centers.

\section{Nursing Homes}

Nursing homes can be run by the Ministry of Family and Social Politics, Directorate General of Services for Persons with Disabilities and Older Adults, other ministries, municipalities, foundations, associations, and minorities to meet the physical, social, and psychological needs of older adults over 60 . Besides these, other nursing homes belong to the private sector. 
Table 3 The Number of Nursing Homes, Their Capacity, and Rate of Their Occupancy, 2015

\begin{tabular}{|c|c|c|c|c|}
\hline $\begin{array}{c}\text { Type of } \\
\text { nursing } \\
\text { home }\end{array}$ & $\begin{array}{c}\text { The } \\
\text { number of } \\
\text { homes }\end{array}$ & $\begin{array}{c}\text { The } \\
\text { capacity }\end{array}$ & $\begin{array}{c}\text { The } \\
\text { population } \\
\text { of cared } \\
\text { people }\end{array}$ & $\begin{array}{c}\text { Occupancy } \\
\text { rate }(\%)\end{array}$ \\
\hline Total & 350 & 28769 & 23132 & 80,4 \\
\hline $\begin{array}{l}\text { Old peoples' } \\
\text { houses under } \\
\text { Directorate } \\
\text { General of } \\
\text { Services for } \\
\text { Persons with } \\
\text { Disabilities } \\
\text { and Older } \\
\text { Adults }\end{array}$ & 131 & 13391 & 12202 & 91,1 \\
\hline $\begin{array}{l}\text { Old peoples' } \\
\text { houses under } \\
\text { other } \\
\text { ministries }\end{array}$ & 2 & 570 & 566 & 99,3 \\
\hline $\begin{array}{l}\text { Old peoples' } \\
\text { houses under } \\
\text { municipalities }\end{array}$ & 21 & 2915 & 2041 & 70,0 \\
\hline $\begin{array}{l}\text { Old peoples' } \\
\text { houses under } \\
\text { Foundations } \\
\text { and } \\
\text { Assemblies }\end{array}$ & 28 & 2324 & 1626 & 70,0 \\
\hline $\begin{array}{l}\text { Old peoples' } \\
\text { houses } \\
\text { belonging to } \\
\text { minority } \\
\text { groups }\end{array}$ & 5 & 508 & 355 & 69,9 \\
\hline $\begin{array}{l}\text { Private Old } \\
\text { peoples' } \\
\text { houses }\end{array}$ & 163 & 9061 & 6342 & 70,0 \\
\hline
\end{tabular}

Source: TurkStat, Statistically Older Adults, 2015; the Ministry of Family and Social Politics (from December 2015). 
Even though the nursing homes are opened under several institutions, the municipalities come one step forward on this issue because the basic service providers are the municipalities. Since 1930, as required by the law, they have been responsible for opening guests' houses, almshouses for groups who are in need, including older adults. Moreover, as it can be seen in Table 3, several non-governmental organizations and a number of private care houses run by minorities and natural, legal people provide older adults with necessary care and social protection (Karagel, 2011, p. 62; TYDYUEP, 2013, p. 12).

There are certain conditions for older adults to be accepted to these care houses or nursing homes. For instance, they have to prove with an income test that they are socioeconomically in need of care. Their health condition comes next. In fact, being healthy and being able to meet their basic needs is the first condition that is necessary to be accepted by these places. In other words, older adults being able to perform their daily activities independently, not having a disability or a disease and not being addicted to drugs or alcohol (Saka and Varol, 2007, p. 20).

\section{Care at Home}

Many studies in today's world show that older adults hold a hope to grow old in an environment where they are used to live with their beloved ones. It is claimed that this is much more humane than nursing homes or care houses no matter how comfortable they are. With this process that is called "ageing in place" older adults live in the society and lead a normal life, and thus they can protect their physical and mental health, and they can get much more pleasure in life. Ageing in place is basically an application that can be included in the category of social-based care for older adults. Moreover, the application of ageing in place is a remarkable step that helps social-based care services to spread.

However, ageing in place does not mean the imprisonment of older adults in the house. That is different from the traditional family care because in this application, experts who have medical, physical, and physiological training are employed, and older adults are aimed to spend a successful ageing period. While doing this, they are not taken out of the environment that they are used 
to. It is aimed that older adults should have a happier ageing period without being exposed to the exclusion from the society. So, it is a formal system applied by the state, which is entirely different from the traditional, informal caring system where wives, children and even grandchildren look after their own older adults.

The application of care at home that can be considered as an example for ageing in place has been actualized in recent periods in Turkey. The application of care at home, as stated in the 10th Development Plan, has been performed with the aim of compensating the deficiency in quality and capacity of older persons' care. Hence, it was definitely stated that the quality and capacity of the care at home institutions would be promoted (10th Development Plan, 2014, p. 44).

In Turkey, care centers for older adults, working under the Ministry of Family and Social Policies, are charged with providing care systems at home as much as they can stay "within the bounds of possibility." However, naturally, there are some conditions for those who want to benefit from care at home system. First of all, they need to be psychologically, physiologically, and physically healthy and they must not have a condition that requires a continuous medical care. In addition, there is another must that the care which is given by family members or other assisting members such as a neighbor or a relative is not sufficient and older adults still need care. The income level of older adults who want to benefit from these places is taken into consideration, too, in the care services by both private sectors and public institutional care houses. Today, there are five care centers for older adults in Turkey founded with this aim and 1076 older adults are provided with care in these facilities (TYDYUEP, 2013, pp. 15-16).

It is possible to change this situation into an advantage by integrating the traditional family solidarity with care at home system. However, it is necessary to approach the situation with a professional perspective and employ a sufficient number of social service officers with enough qualifications. This care at home system, which started legally in 2005, has not been common enough because these necessities were not fully activated. Care at home service by the private sector is provided for an insufficient number of older adults only in big cities (Cankurtaran and Eker, 
2007, p. 68). For this reason, it can be said that Turkey has a very long way to increase the number of these private or public care systems.

\section{Precautions in the Governmental Programs and Development Plans for Older Adults}

The planned development period in Turkey started in 1963, and it continues. Development plans cover 5-year periods, and the $10^{\text {th }}$ and the recent development plan covers the years 2014-2018. The development plans are official documents that reveal the perspectives on older persons' care problem in years in the clearest way in Turkey together with government programs. These plans and programs coincided with all the stages of the demographical transition period of the population. That is, not only the first periods when the population was still young, and there was not the issue of ageing society, but also the periods when the rate of older adults in the third age started to increase, and the issue of older persons' care started to become a serious problem. The development plans and government programs continued to be published along with these periods. Naturally, these plans and programs also show to what extent Turkey was aware of this new situation and what kind of precautions it was planning against the projections pointing at the fourth age matter. In short, these plans and programs clearly reveal whether there was a change in politics after the increase in the old age population in Turkey.

If it is necessary to make a general assignation, the expressions concerning older persons' care in the development plans have not changed in time together with the increase in old age population. From this result, it is understood that Turkey was not aware of the fact that there would be different needs for different age groups and it did not make a separation in the care and social protection precautions according to ageing categories. A similar situation is a pic for the question in the government programs. First of all, old age is holistically evaluated without being separated into sub-categories in almost all government programs. An expected result of this is that all the steps were taken with an assumption that "older adults have monotype needs." 
Moreover, ambiguous promises were given about how to meet these requirements.

At the same time, especially from the beginning of the twenty-first century, a common expression that was observed in almost all government programs was the emphasis that older persons' care was the family responsibility. Shortly, in every program, it was promised that care is a priority and that it is important to meet older adults' needs, yet it was not discussed what these requirements were and which policy would be used to meet them.

Furthermore, older people were not mentioned under a separate heading in the programs that coincided with the beginning of the planned development years. Older persons were mentioned together with the people with disabilities who lost their capacity to work and children in need. Also, many ambiguous expressions were used such as taking precautions within the bounds of financial possibility. This perspective and the attitude towards older persons' care was kept unchanged in many programs until today.

Another common point in the government programs was the emphasis that older people were not only the government's responsibility. Collaborations with voluntary foundations would be made. The collaboration between the informal voluntary foundations and the state is necessary only when they act together in older persons' care and share the roles. In other words, the state must always be the leading actor in social assistance and social service. Other informal and voluntary applications only complete and help the state. When the government programs and development plans are examined, it is understood that the leading role in older persons' care is dominantly the informal and voluntary mechanisms, mainly the family. That is, older persons' care is tried to be solved by traditional solidarity networks among individuals. This method may not seem to be a problem when the population was young and dynamic, and the traditional family structure was not ruined. However, even in the periods when the rate of older adults in the third and fourth age category started to increase rapidly, Turkey was observed to be in an attempt to leave this responsibility to the informal and voluntary mechanisms. 
Therefore, Turkey does not seem to be aware of the fourth age problem and the needs of this category; it applies the approaches for the third age that it used to apply to previous periods.

The need of institutionalization was firstly mentioned at the beginning of the 1970s, 50 years after the proclamation of the Republic. As well as being very late, these first discussions were rather weak. For instance, it was mentioned that care houses for the poor and weak citizens would be built $\left(31^{\text {st }}\right.$ Government Program; $3^{\text {rd }}$ Development Plan, 1973), and it did not go further than being a kindly promise. As it can obviously be seen in Table 3 , a desirable institutionalization has not been achieved up to date. In addition, rights-based and institutional promises were continuously emphasized to go with collaboration with voluntary and informal mechanisms.

It is observed that the emphasis on older adults increased both in the government programs and development plans in later years. Also, the state started to have a self-criticism about older persons' care. According to this, it was obviously stated that the content of the social services and social assistance programs were very limited; the number of those who benefit from these services was very low; the funds that were to be put aside from the public sources was not enough (4th Development Plan, 1979, p. 143). These periods were when the immigration from villages to cities got faster, and the family structure started to change. While the traditional family structure was replaced by nuclear families, the period when the female children were in school extended. This led them to query their roles inside the family. The state tried to fill in this gap with the emphasis that private entrepreneurship for older persons' care would be promoted (4th Development Plan, 1979, p. 285). This situation shows that the state has not changed its perspective to older persons' care; instead of developing rightsbased mechanisms, it looks for alternatives to set collaborations.

Apart from the emphasis on the institutionalization, the promises to "let all older persons in need have a salary"-which can be called as another rights-based approach, started to go up together with the law which was put into effect in 1976. This promise is actually suitable for the state's general perspective to older persons' care issue. Because older persons services have 
been designed for the indigent old people and the financial dimension of the problem has been highlighted. Instead of applying welfare policies for all older adults, the state firstly felt responsible for providing them with social protection for the indigent ones. Yet, in time, even if the financial possibilities have increased, this policy has stayed the same.

The $6^{\text {th }}$ Development Plan covering the years between 1990 and 1994 is certainly separated from the other plans. Because of the idea that older persons' care is a problem that must be solved inside the family was clearly and definitely expressed for the first time in these years, and it was repeated in the same way in other plans, too. That is, older persons' care by the family members was mentioned as the certain target instead of institutional care. It was stated that the limited care and protection service the state would offer to old people would be designed mainly for the family, not directly for older adults themselves. By doing so, the state wants to institutionalize the function of the family $\left(6^{\text {th }}\right.$ Development Plan, 1990, p. 305).

While the state is promoting the emphasis on the family, it seems aware of the insufficiency of the informal mechanisms. As a matter of fact, together with the beginning of the 2000s, it was observed that the state started to be aware of the rapid increase in old age population. After it was determined that this increase in old age population would raise the need for the Old Peoples' House and Older Adults' Counselling Centre (8th Development Plan, 2001, p. 111), it was stated that a new institutional structure responsible for the management and the coordination of designing every kind of social service and social assistance program would be formed with the aim of improving these social services.

As we come to our time, the emphasis on the rise of old age population has been mentioned together with the determinations concerning the changes in the family structures. In the $9^{\text {th }}$ Development Plan, which covers the years 2007 and 2013, after stating that the family may not do its traditional responsibilities, promises were given such as the importance of older persons' services would rise, and there would be more various services. As a result of this context, the support of older persons' care services was promised for the first time; it was also promised that the 
quantity and quality of the old peoples' houses would be increased. In other words, while the state was talking about the number of the institutional and rights-based investments would be made and, it was trying to revive the traditional role and responsibility of the family and looking for new ways and methods for older persons' care at home.

The most detailed determination of older persons' care and a plan of promises is the $10^{\text {th }}$ Development Plan. In this plan, it was stated that social assistance and standards need to be created, qualified staff needs to be employed, controls must be increased, and the services for older adults must be diversified and made common. In addition, it was expressed that the quality and quantity of the institutional care would be increased without taking older adults out of their environment $\left(10^{\text {th }}\right.$ Development Plan, 2014, pp. 43-44).

Another focus was made on the solidarity between generations. It was also stated that the capacity of the local public services would be increased with the aim of easing the access to these services because of the decrease in the population density in villages and innovative models would be developed. It was also focused that it was necessary to increase older persons' care services in order to encourage more women to join the labor force. It was underlined that social assistance and services need to be offered as family-based in the framework of the Program of Protection of the Family Dynamics Population Structure (10th Development Plan, 2014).

As it can be understood from this last plan, the state has just started to understand the seriousness of older persons' care issue in Turkey. Even though very clear rights-based and institutional promises were given, it is still at the stage of intention and planning. Moreover, there are many insufficiencies in the application.

Turkey is a country, which is ageing extremely fast on the one hand and which is going through a family-based transformation process on the other; so, it will be right to apply much more systematic and rights-based strategies in such a country. However, care services in Turkey are problematic. The staffs are sufficient neither in numeric nor the level of 
specialization. The social service staff, such as professional therapists, physiotherapists, geriatric psychiatrists, and geriatric nurses can only be found commonly in big cities (Cankurtaran and Eker, 2007, p. 68).

Because of this institutional insufficiency for infrastructure, the governments in Turkey prefer leaving the issue of older persons' care to informal and voluntary mechanisms, mainly the family. These informal and voluntary mechanisms can only be used to complete the gaps of the state; they cannot fully replace the state's institutional and rights-based responsibilities and they should not. Despite this universal fact, it is understood that the issue of older persons' care is recently included in the government programs and development plans. As a matter of fact, the state emphasizes to empower the informal mechanisms instead of rights-based and systematic applications. Turkey urgently needs specific policies and programs for the fourth group where old age population is rapidly increasing, because it is not possible to meet the needs of the fourth age group with steps and promises concerning the third age group.

\section{Conclusion}

It is certain that Turkey is going through a demographically new period. The average lifespan is increasing day by day due to some progress such as improvements in the nutrition and healthcare, developments in general welfare, and slowdowns in birth-rate. That is why; the rate of older adults in the total population is growing a lot faster compared to those in other age groups. This increase in old age population will lead to serious problems for the living standards of older adults, and their needs, especially for social and special care services. There is an incompatibility between formal and informal mechanisms when meeting the caring requirements of older persons and providing them with social security services. The traditional solidarity of families has become the principal mechanism responsible for older persons' care for long years, so the formal structure has become extremely insufficient. This family-based caring system has lost its importance in today's world because of a series of socio-economic and cultural reasons. Despite this, the state is understood to have a 
tendency to reactivate these informal mechanisms, and it tends to solve the problem by having a collaboration with them instead of accepting itself as the fundamental responsibility for older persons' care.

There is a lot larger old age population in today's world, and they do not belong to one population group. The distinction between the third and the fourth age among old people has been clearer for a long time, and this distinction will be much sharper in the very near future. It is also predicted that especially the fourth age group will increase rapidly. Therefore, it has become difficult to solve this population ageing problem and the care needs of older persons via informal networks. The state certainly needs to develop formal and rights-based methods. However, when the development plans and government programs covering the last 50 years are examined, it is understood that Turkey is not aware of the urgency of the problem. It still approaches this serious issue with the wording and precautions used when the old age population was less dense. It is not possible yet to claim that precautions and declarations related to the fourth age group have been made. The state is in an effort to solve this fourth age problem which is approaching rapidly with old methods and is focusing the importance of the family, and it goes on making collaboration plans with informal, voluntary, and private sectors.

These informal mechanisms which are directly effective on the older persons caring system and having a united society and interpersonal solidarity should, of course, be included in the care system as long as they do not take over the rights-based roles that normally belong to the state. Otherwise, a very critically sensitive issue such as the social security of older adults will have to be left to the philanthropist applications and benevolent feelings.

In older persons' care, it is of course, very important not to take older adults out of their natural environment. This can be summarized as ageing in place, and in this concept, older adults get older peacefully, happily and by joining the society. In Turkey, in fact, the governments are trying to encourage those people to live with their families instead of putting them into public buildings. The family and the fact that old person is not taken out of his natural environment has a great importance in older 
persons' care. This can be summarized as "ageing in place" because they get older in their natural environments, happily, peacefully and taking active roles in the society. In Turkey, the government is trying to encourage older adults to grow older inside their homes near their relatives instead of living in nursing homes. This attempt is highlighted in almost all development plans and governmental projects. However, the policy for ageing in place requires more than that. First of all, ageing in place should be done via the social experts employed by the state rather than informal family solidarity. Especially, the project of older persons' care at home is an important step as promised in recent development plans and governmental programs. However, it has a limited area for the application. The rights-based older persons caring system will be set by employing efficient expert staff, by holding training programs and seminars about the issue and by giving technical support.

For the final word, even though it has a very rapidly ageing population structure, Turkey is understood to be slow at taking necessary precautions in a formal context. Traditional familybased informal mechanisms are successful at older persons' care to a point, and after that point, formal, systematic, foundational, and rights-based applications are definitely necessary. However, before that, Turkey needs to realize that there is a difference between "the third age" and "the fourth age," and that older adults have different requirements at various stages of the life course. Only after this, it will be able to produce different policies for diverse needs and demands of old age groups.

\section{References}

10th Five-Year Development Plan 2014-2018. (2014). Retrieved from www.mod.gov.tr/Lists/RecentPublications/Attachments/75/The \%20Tenth\%20Development\%20Plan\%20(2014-2018).pdf

31 st Government Program. (1987). Retrieved from www.tbmm.gov.tr/hukumetler/HP31.ht

4th Five-Year Development Plan 1979-1983. (1979). Retrieved from www.kalkinma.gov.tr/Lists/Kalknma\%20Planlar/Attachments/6/ plan4.pdf 
6th Five-Year Development Plan 1990-1994. (1990). Retrieved from www.kalkinma.gov.tr/Lists/Kalknma\%20Planlar/Attachments/4/ plan6.pdf

AITFS-Ministry of Family and Social Policy. (2014). An

Investigation of Turkish Family Structure, Proofs, Recommendations. Ankara.

Akgeyik, T. (2006). Sosyal Güvenlikte Reform Eğilimleri.

Geleneksel Sistemlerden Bireysel Emeklilik Programlarına Dönüşüm [Reform tendencies in social security: Transformation from traditional systems to individual pension programs]. Sosyal Siyaset Konferanslarl Dergisi. (51), 47-99.

Barnes, S. F. (2011). Third Age-The Golden Years of Adulthood. Retrieved from http://calbooming.sdsu.edu/documents/TheThirdAge.pdf

Bayoğlu, A. S. (2011). Yaşlanma Sürecinde Sosyal Dışlanmaya Karş1 Güçlendirme Temelli Sosyal Hizmet Müdahalesi [Social service intervention based on empowerment against social discrimination in the process of ageing]. In Y. Özkan (Ed.), Sosyal Dışlanma ve Aile Sosyal Hizmet Müdahalelerinde Güçlendirme Yaklaşımı [Social discrimination and the family: Approach of empowerment in social service interventions] (pp. 123-136). Ankara: Maya Akademi.

Büken, N. Ö. (2010). Fiziksel Tip ve Rehabilitasyonda Yeni Ufuklar [New horizons in physical medicine and rehabilitation]. Yaşlı Sağlığ1 [Old persons' health], Güneş Tıp Kitapevleri. Geriatri ve Etik, 31-53.

Cankurtaran, E. S., \& Eker, E. (2007). Being Elderly in a Young Country: Geriatric Psychiatry in Turkey. International Journal of Mental Health Systems, 3(36), 66-72.

Daniş, D. (2014). Demografi. Nüfus Meselelerine Sosyolojik Bakış [Demography: Sociological look to population issues]. Retrieved from www.acikders.org.tr/mod/resource/view.php?id=3054

Devlet Planlama Teşkilatı (Turkey). (2001). Long-term Strategy and Eighth Five Year Development Plan 2001-2005. Ankara: State Planning Organization. Retrieved from www.kalkinma.gov.tr/Lists/Kalknma\%20Planlar/Attachments/2/ Eight\%20Five-Year\%20Development\%20Plan\%2020012005.pdf 
Finch, C. E. (1996). Biological Bases for Plasticity during Aging of Individual Life Histories, The Life-Span Development of Individuals. In D. Magnusson (Ed.), The Lifespan Development of Individuals: Behavioral, Neurobiological, and Psychosocial Perspectives: A Synthesis (pp. 488-511). Cambridge, UK:

Cambridge University Press.

Guidance for the Elderly. (2016). Retrieved from

www.yaslilikrehberi.org/haberler/3-ya\%C5\%9Fueniversitesi.aspx

Güler, Ç. (1998). Yaşlılıkta Tanımlar ve Yaşlılık Üstüne Söylenenler [Definitions for Old Age and Expressions on Ageing]. Geriatri, 1(2).

Hablemitoğlu, Ș., \& Özmete, E. (2010). Yaşlı Refahı [Old Persons' Welfare]. İstanbul: Kilit Yayınları.

Imamoğlu, E. O. (1987). An Interdependence Model of Human

Development. In Ç. Kağıtçıbaşı (Ed.), Growth and Progress in

Cross-cultural Psychology (pp. 104-112). Lisse, Nedherlands:

Swets \& Zeitlinger.

Kannisto, V. (1996). The Advancing Frontier of Survival: Life Tables for Old Age. Odense: Odense University Press.

Karagel, D. Ü. (2011). The Distribution of Elderly Population in Turkey and the Factors Effecting This Distribution.

International Journal of Social Sciences and Humanity Studies, 3(1), 59-69.

Karahan, A., \& Güven, S. (2002). Yaşl11ıkta Evde Bakım [Home care at old age]. Geriatri. (5), 155-159.

Keyder, Ç. (1982). Dünya Ekonomisi İçinde Türkiye (1923-1929)

[Turkey in world economy 1923-1929]. Ankara: Yurt Yayınları.

Kinsella, K., \& Gist, Y. J. (1995). Older Workers, Retirement, and

Pensions: A Comparative International Chartbook. Washington,

DC: United States Bureau of the Census.

Kinsella, K., \& He, W. (2009). International Population Statistics Reports. Washington, DC: U.S. Census Bureau.

Koç, İ., Eryurt, M. A., Adalı, T., \& Seçkiner, P. (2010). Türkiye'nin

Demografik Dönüşümü [Demographic shift of Turkey]. Ankara:

Hacettepe Üniversitesi Nüfus Etütleri Enstitüsü [Hacettepe

University, Demographic Research Institute].

Laslett, P. A. (1991). Fresh Map of Life: The Emergence of the Third Age. Cambridge, MA: Harvard University Press. 
Lee, R. (2003). The Demographic Transition: Three Countries of Fundamental Change. Journal of Economic Perspectives, 4(17), 167-190.

Manton, K. G. (2001). Aging and Health in Old Age. In N. J. Smelser \& P. B. Baltes (Eds.), International Encyclopaedia of the Social and Behavioural Sciences (pp. 304-310). Oxford: Elsevier.

Neugarten, B. L. (1974). Age Groups in American Society and the Rise of the Young-Old. Annals of the American Academy of Politics and Social Sciences. (9), 187-198.

Olshansky, S. J., Carnes, B. A., \& Désesquelles, A. (2001). Prospects for Longevity. Science. (291), 1491-1492.

Özbay, F. (2015). Dünden Bugüne Aile, Kent ve Nüfus [Family, city and demography from past to today]. İstanbul: İletişim Yayınlar1.

Özmete, E. (2012). Yaşlanırken Başarılı Yaşlanma [On the way of ageing: Successful ageing]. Biz Bir Aileyiz [We are family]. Aile ve Sosyal Politikalar Bakanlı̆̆ Yayını, 1(1), 1-5.

Öztürk, H. (2015). Yaşlanma ve Kırsal Yaşlılık Mevcut Durum Raporu [Report of present situation in old age and ageing in rural areas]. Ankara: Bask1.

Republic of Turkey Prime Ministry State Planning Organization. (1973). A Summary of the Third Five Year Development Plan, 1973-1977. Ankara. Retrieved from www.kalkinma.gov.tr/Lists/Kalknma\%20Planlar/Attachments/7/ plan3.pdf

Rowe, J. W., \& Kahn, R. (1987). Human Aging: Usual and Successful. Science, New Series. (237), 143-149.

Saka, Ö., \& Varol, N. (2007). Institutional and Community Care for Older People in Turkey. Eurohealth, 13(3), 20-22.

SHCEK. (2006). Yaşlılığa Genel Bakış [A general outlook on the issue of old age]. Retrieved from www.shcek.gov.tr/hizmetler/yasli/Yasliliga_Genel_Bakis.asp

Shorter, F. C. (1985). The Population of Turkey after the War of Independence. International Journal of Middle East Studies, 17(4), 417-441.

Smith, J. (2000). The Fourth Age: A Period of Psychological Mortality? Berlin: Max Planck Forum. 
SPO-State Planning Organization. (2007). The Situation of Elderly People in Turkey and National Plan of Action on Ageing. Ankara.

Teitelbaum, M. S. (1975). Relevance of Demographic Transition Theory for Developing Countries. Science, New Series, 188, $420-425$.

TÜSIAD. (1999). Türkiye'nin Firsat Penceresi; Demografik Dönüşüm ve İzdüsümleri [Turkey's window of opportunity; demographic shift and projections], No TÜSİAD-T/99-1-251.

TYDYUEP - TC Aile ve Sosyal Politikalar Bakanlığ [Ministry of Family and Social Policies], Engelli ve Yaşlı Hizmetleri Genel Müdürlüğü [Directorate General of Services for Persons with Disabilities and Older Adults]. (2013). TYDYUEP - Türkiye'de Yaşlıların Durumu ve Yaşlanma Ulusal Eylem Planı Uygulama Programı [Older Adults' Situation in Turkey and National Action Plan of Ageing]. Ankara.

UNFPA. (2015). World Population Report. Retrieved from www.unfpa.org/sites/default/files/sowp/downloads/State_of_Wo rld_Population_2015_EN.pdf

United Nations. (2001). World Population Ageing 1950-2050.

Retrieved from

www.un.org/esa/population/publications/worldageing19502050/ pdf/001world.pdf

United Nations. (2015). World Population Ageing 2015. New York, NY.

Vaupel, J. W., Carey, J., Christensen K., \& et.al. (1998).

Biodemographic Trajectories of Longevity. Science, New Series. (280), 855-860.

Weiss, R. S., \& Bass, S. A. (2002). Challenges of the Third Age: Meaning and Purpose in Later Life. Oxford England, New York: Oxford University Press.

World Health Organization (WHO). (2002a). Proposed Working Definition of an Older Person in Africa for the MDS Project.

World Health Organization (WHO). (2002b). What is Active Ageing. Retrieved from www.who.int/ageing/active_ageing/en/

World Health Organization (WHO). (2004). A Glossary of Terms for Community Health Care and Services for Older Persons.

Retrieved from www.who.int/kobe_centre/ageing/ahp_vol5_glossary.pdf?ua=1 
World Health Organization (WHO). (2010). Definition of an Older or Elderly Person. Retrieved from www.who.int/healthinfo/survey/ageingdefnolder/en/index.html World Health Organization (WHO). (2016). Healthy Ageing. Retrieved from www.euro.who.int/en/health-topics/Lifestages/healthy-ageing/healthy-ageing

Yüceşahin, M. M. (2011). Küresel Bir Süreç Olarak Demografik

Dönüşüm. Mekânsal Bir Değerlendirme [Demographic transformation as a global process: A spatial evaluation]. Coğrafi Bilimler Dergisi. (9), 11-27. 